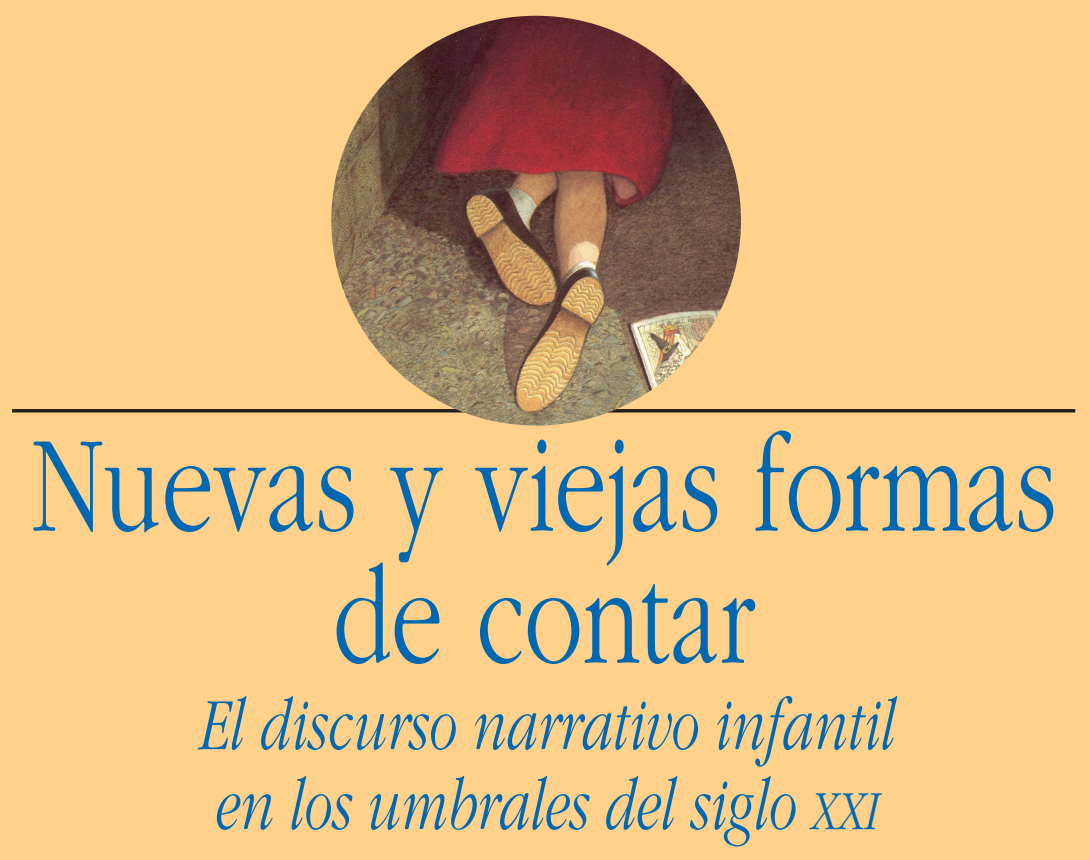

Rosa Tabernero Sala

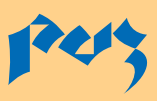

Prensas Universitarias de Zaragoza 

NUEVAS Y VIEJAS FORMAS DE CONTAR

El discurso narrativo infantil

en los umbrales del siglo XXI 



\section{NUEVAS Y VIEJAS FORMAS DE CONTAR \\ El discurso narrativo infantil \\ en los umbrales del siglo XXI}

Rosa Tabernero Sala

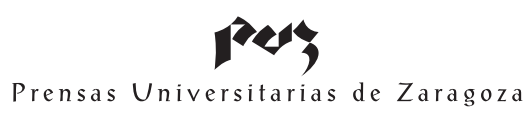




\section{FICHA CATALOGRÁFICA}

TABERNERO SALA, Rosa

Nuevas y viejas formas de contar : el discurso narrativo infantil en los umbrales del siglo XXI / Rosa Tabernero Sala. — Zaragoza : Prensas Universitarias de Zaragoza, 2005

280 p. : il. col. ; $22 \mathrm{~cm}$. - (Humanidades ; 53)

ISBN 84-7733-795-0

1. Literatura infantil-Historia y crítica. I. Prensas Universitarias de Zaragoza. II. Título. III. Serie: Humanidades (Prensas Universitarias de Zaragoza) ; 53

82-93.09

No está permitida la reproducción total o parcial de este libro, ni su tratamiento informático, ni la transmisión de ninguna forma o por cualquier medio, ya sea electrónico, mecánico, por fotocopia, por registro u otros métodos, ni su préstamo, alquiler o cualquier forma de cesión de uso del ejemplar, sin el permiso previo y por escrito de los titulares del Copyright.

(C) Rosa Tabernero Sala

(C) De la edición española, Prensas Universitarias de Zaragoza

$1 .^{a}$ edición, 2005

Ilustración de la cubierta: José Luis Cano

Colección Humanidades, n. ${ }^{\circ} 53$

Directora de la colección: Rosa Pellicer Domingo

Editado por Prensas Universitarias de Zaragoza

Edificio de Ciencias Geológicas

C/ Pedro Cerbuna, 12

50009 Zaragoza, España

Prensas Universitarias de Zaragoza es la editorial de la Universidad de Zaragoza, que edita e imprime libros desde su fundación en 1542.

Impreso en España

Imprime: INO Reproducciones, S. A.

D.L.: Z-2869-2005 
Para Alfonso, como cada día

Para Carmela y Javier, mi mejor historia 


\section{PRÓLOGO}

No hay que retroceder muchos años para llegar al tiempo en que los libros que leian los niños, pese a constituir su pasillo de entrada al universo de la ficción, carecian de la aureola de lo literario, y por ello estaban ausentes de los estudios que producía, desde las más variadas perspectivas, la ciencia literaria. Los debates teóricos sobre el propio concepto de literatura y sobre sus métodos de análisis y fines que ocuparon el siglo XX desde sus inicios jamás tuvieron en cuenta estas creaciones para niños como objeto de sus reflexiones hasta que, en un momento dado, algunas voces aisladas pero apoyadas en la consistencia de sus argumentos trataron de aplicar a los libros infantiles los mismos métodos de análisis con que se consideraba la literatura en general. Pero más adelante, cuando se abre paso la concepción de la literatura como un producto cultural, cuando se impone la evidencia de su naturaleza comunicativa y se reconoce la importancia del lector y el contexto social en que se inscribe la obra, es ya muy difícil negar la existencia y la validez de la literatura infantil desde los mismos presupuestos teóricos que sirven para interpretar la literatura canónica. Porque no sólo crece espectacularmente la creación y edición de libros para niños (un fenómeno social intimamente relacionado con la creciente importancia que desde diferentes ámbitos se otorga a la lectura que no se puede ignorar y al que hay que dar explicación), sino que la propia ciencia literaria proporciona las bases sobre las cuales justificar y explicar el fenómeno literario en relación con un receptor especifico como es el receptor infantil.

En estas circunstancias, la investigación y la reflexión sobre la literatura que leen los niños se ha ido abriendo paso en nuestro país a partir de las obras pioneras de algunos historiadores y teóricos como Carmen Bravo-Villasante, Jaime García Padrino o Juan Cervera, secundados después por un grupo de estudiosos, cada vez más amplio, integrados en el ámbito académico y univer- 
sitario. Y en esta linea de trabajo se inscribe la obra de Rosa Tabernero que el lector tiene en sus manos, basada en lo esencial en su tesis doctoral, ampliamente revisada y reformulada: un paso de gran importancia en la consolidación de una tradición investigadora que aplica los conceptos y métodos de teorías de la literatura como la pragmática, la estética de la recepción o la narratología a la literatura infantil, mostrando, al mismo tiempo, la validez del método de análisis y la condición literaria de esta clase de obras que ya circulan socialmente con la sanción de lo literario.

El análisis de estos textos en el seno de un acto de comunicación desvela dónde radica su identidad especifica. La dinámica que interrelaciona emisor, receptor y texto, y la especial condición del receptor como un sujeto inmaduro, inestable y en proceso de aprendizaje, conduce al uso de unas estrategias textuales determinadas, que Rosa Tabernero identifica y esclarece desde la hipótesis, ampliamente confirmada, de la doble recepción como rasgo definitorio más importante de esta literatura y como el principal motor de innovación en su discurso. En tanto que el receptor infantil es un sujeto en crecimiento y educable, su acceso al texto literario siempre tiene lugar mediante intermediarios adultos, que terminan constituyéndose, se quiera o no, en parte de ese lector modelo que condiciona el discurso desde su origen. Estamos, pues, ante textos ambivalentes que se explican por el receptor dual al que se dirigen. El riguroso análisis que aplica la autora de este estudio a una significativa muestra de la literatura infantil y juvenil de los últimos años pone de relieve dicha ambivalencia en el discurso narrativo etiquetado como infantil, y señala las marcas o elementos que la demuestran. Contribuye con ello a un conocimiento más ajustado y preciso de lo que es esencial en esta clase de literatura que todavía muchos se empeñan en considerar un género.

Pero si el enfoque literario de este trabajo y, en consecuencia, el interés de sus resultados es uno de sus principales valores, hay que señalar otro aspecto no menos destacado del mismo: su contribución al establecimiento de unas bases sólidas para la educación literaria.

Cada vez sabemos más sobre cómo se produce el aprendizaje literario; han sido la psicología y la propia teoría de la literatura las que han clarificado los mecanismos y procesos a través de los cuales el ser humano adquiere la competencia necesaria para comprender e interpretar esa especial forma de lenguaje que es la literatura. Sabemos, por ejemplo, que la forma en la que están configurados los textos es determinante en este aprendizaje, ya que cada uno de los 
elementos del discurso literario pone en marcha unos mecanismos de reconocimiento, anticipación, elaboración y confirmación de hipótesis sobre los que se asienta, entre otros, el aprendizaje. Sabemos, en consecuencia, la importancia de que los textos a los que el niño o la niña tienen acceso sean los adecuados a su momento madurativo y permitan que los mecanismos de aprendizaje funcionen correctamente. Para poder establecer los itinerarios lectores que realmente conduzcan a una competencia literaria plena es preciso conocer cómo son los textos; puesto que parece inherente a ellos la existencia de un mediador, cuanto mejor se conozcan las claves de su discurso, mejor se podrá abordar la actuación de este intermediario social. Por tanto, si valoramos sobremanera el enfoque literario de este estudio (frente a las aproximaciones psicopedagógicas que tan habituales han sido, y siguen siendo, a los libros para niños), es porque, además de integrar estas obras en el ámbito de la ciencia literaria, es el enfoque que mejor contribuye a determinar las condiciones sobre las que debe asentarse la educación literaria más eficaz.

La importancia de enseñar a leer literariamente, es decir, de formar individuos capaces de apreciar el sentido de las creaciones literarias, es reconocida como una urgente demanda de nuestra sociedad, puesto que, como afirma Dario Villanueva en la introducción al Curso de teoría de la literatura, "la literatura dejará de existir, al menos con la plenitud que le es consustancial, en el momento en que no existan individuos capaces de saber leerla desde esa complejidad de los dos códigos que la obra literaria incorpora [...]». La educación literaria es una tarea prioritaria que debe ser "eficazmente fecundada por los nuevos hallazgos de las pesquisas teóricas de más altos vuelos", añade. No hay duda de que las pesquisas que ha realizado la autora de este libro sobre esa tan necesaria y determinante literatura inicial resultarán felizmente fecundas.

María Victoria Sotomayor SÁEZ 


\title{
INTRODUCCIÓN
}

\author{
Cuando se acerca el fin, ya no quedan imágenes del \\ recuerdo; sólo quedan palabras. \\ (Jorge Luis BORGES, «El inmortal», en El Aleph)
}

Palabras imaginadas, palabras ilustradas, palabras que alimentan el mejor de los mundos posibles.

Hoy más que nunca, en los umbrales del siglo XXI, se dibuja la necesidad de reflexionar sobre un discurso como el literario infantil - especialmente el narrativo-, cuyos parámetros van modificándose rápidamente, al compás de las épocas, de la propia evolución de los receptores y, por qué no decirlo, al albur del mercado editorial.

Descubrir las claves de un discurso que nos está desbordando ahora mismo con una cantidad ingente de propuestas, unas más conservadoras, otras más arriesgadas o experimentales, unas de mayor calidad, otras de menor, obtener las llaves de un discurso que se debe adaptar a un receptor que evoluciona de una forma vertiginosa, de un discurso que debe considerar nuevas formas, incluso de transmisión, es una empresa incierta que implica la asunción de ciertos riesgos derivados de su rápida progresión.

Lejos, en algunos casos, de la tradicional concepción formativa que se le ha atribuido desde sus comienzos, el discurso narrativo infantil se intenta adaptar a un nuevo receptor, el del siglo XXI.

Desde las perspectivas que abren los paradigmas metodológicos que consideran el hecho literario como un acto puramente comunicativo, se 
podrá caracterizar el discurso literario infantil como una relación peculiar que se establece entre emisor y receptor. A este respecto, las teorías de Eco (1987: 79) que definen el texto como «un producto cuya suerte interpretativa debe formar parte de su propio mecanismo generativo" nos han facilitado el marco metodológico idóneo para reconocer las estrategias específicas, así como Genette (1982; 1987; 1989; 1993; 1998), Bajtin (1985) y otros narratólogos (Bal, 1985; García Landa, 1998) nos han aproximado a un discurso ciertamente controvertido. El enfoque comunicativo ha sido de especial utilidad en estas páginas ya que la figura del mediador se muestra como uno de los elementos esenciales del ámbito que nos ocupa. Este mediador adulto con el que ahora cuentan los últimos estudios ${ }^{1}$ funciona como estrategia generadora del propio discurso y condiciona sobremanera todo lo que se pueda concretar acerca del mismo y, de este modo, contribuye a definir uno de los rasgos más específicos de la literatura infantil que no es otro que el de la duplicidad de la recepción. ${ }^{2}$

Cuando se trata de mediadores, se menciona a instituciones educativas, maestros, padres y también a los editores, que, en última instancia, sancionan la entrada de las obras en un mercado que soporta una competencia extrema y en el que los fracasos implican un precio. Por otra parte, no se puede entender este discurso sin tener en cuenta que la presencia del adulto resulta fundamental en el proceso de transmisión, puesto que el componente afectivo es decisivo en la aproximación al hecho literario. El hablar de libros o el compartir las recepciones es, sin duda, uno de los mejores procedimientos para crear hábitos de lectura o para trabajar la educación literaria, de tal modo que la recepción compartida resulta la clave de la consecución posterior de la fascinación por la literatura.

Graciela Montes (1999: 67) ilustra muy bien esta vinculación de lo literario a los «objetos, las voces, los olores, las temperaturas, las texturas»:

¿Es posible separar la literatura de sus circuitos, de los cuerpos, de los objetos, de los contextos materiales, rituales y simbólicos, de los escenarios donde se actualiza?

1 Cf. Colomer, 1999; Mendoza, 2001; Borda, 2002; Lluch, 2003; Obiols, 2004; García Padrino, 2004.

2 Cf. Shavit, 1986; Wall, 1991. 
En definitiva: ¡es posible separar la ficción de quien la transmite? Indudablemente no lo es.

Además, el discurso del que nos ocupamos combina con sorprendente naturalidad las nuevas y las viejas formas en un intento de adaptarse a un receptor que concilia un nuevo entorno social y educativo con ecos de los referentes de la siempre eterna tradición oral. Indudablemente, en los últimos años, bajo los auspicios de la posmodernidad, el desconcierto se ha instalado en un discurso en continua evolución. En definitiva, nuevas formas de contar que subsumen las antiguas en el afán de dirigirse a un receptor que combina asimismo las premisas del siglo XXI con resonancias de la tradición más antigua y universal.

Con la finalidad de abarcar un panorama ya de por sí complicado, hemos distribuido las siguientes páginas en tres capítulos y una coda. El primer capítulo corresponde a una exposición de los diferentes aspectos que deben ser tratados en el ámbito de la literatura infantil desde los estudios desarrollados durante el siglo $\mathrm{XX}$, hasta la educación literaria directamente vinculada a este tipo de discurso. Los dos capítulos restantes se han reservado para el análisis del discurso narrativo infantil.

El capítulo segundo se centra en una introducción al esquema comunicativo del discurso literario infantil y en el esbozo de los principales problemas a los que se enfrenta cualquier trabajo de las características del que nos proponemos elaborar: emisor, doble recepción, importancia de los sistemas no verbales, la literatura infantil como producto de mercado, etc. Insistimos en la importancia de los sistemas no verbales, sobre todo de la ilustración, como elemento específico del discurso literario infantil del que parte la mayoría de las propuestas innovadoras de calidad. El marco peritextual es también estudiado en la medida en que se muestra de vital importancia en lo que a la caracterización del discurso y de su receptor se refiere.

El tercer capítulo, el más extenso, analizará cada una de las instancias enunciativas propias del hecho que nos ocupa: autor/autor textual, narrador, narratario, lector/ lector textual, con la finalidad de ir definiendo el funcionamiento de las mismas y su influencia en la configuración del discurso.

En lo que respecta a la selección de las obras mencionadas en el transcurso de este trabajo, hemos optado por centrarnos en el género narrativo 
por ser el más desarrollado en el ámbito del discurso literario infantil, tanto en el número de publicaciones presentes en el mercado, a juzgar por las reseñas publicadas en los catálogos de las diferentes editoriales, en revistas especializadas y de divulgación, como en lo que concierne a la utilización en el medio escolar en virtud de la formación de la competencia literaria infantil.

La elección de la época - finales del siglo XX, principios del XXIviene justificada por el hecho de que la narrativa producida a partir de los años setenta parece presentar rasgos bien diferentes de la publicada anteriormente. La producción literaria ofrecida a los niños está concebida en virtud de la consideración que de la infancia se tiene en cada momento. Evidentemente, el niño que forma parte de una sociedad que ha valorado la infancia y que defiende unos presupuestos propios de un estadio democrático y posindustrial, ha de satisfacer unas necesidades diferentes que se plasman en un discurso literario también distinto. De este modo, temas que no habían sido tratados hasta ahora en las creaciones dirigidas a los más pequeños, como la interiorización de los conflictos, el dolor o la muerte, entre otros, aparecen en una literatura que tradicionalmente los había soslayado.

El hecho de que temáticamente la narrativa infantil de este tiempo ofrezca novedades dignas de tener en cuenta nos ha llevado a pensar que no sólo han evolucionado los temas sino también la forma de contarlos.

Variados han sido los criterios considerados a la hora de realizar la selección de las obras. En primer lugar, los estudios de corte diacrónico avalados por autores de reconocida solvencia dentro del campo de la literatura infantil y juvenil han sido de gran utilidad. ${ }^{3}$ Asimismo, se han tenido en cuenta los premios literarios de prestigio. ${ }^{4}$ De inestimable ayuda nos

3 Obras de corte diacrónico como las de Bravo-Villasante (1985; 1988), Cendán Pazos (1986), Cubells (1990), García Padrino (1992) o Colomer (1992a;1992b; 1992c; 1999) nos han servido de guía en la relación final ya que la perspectiva histórica ayuda a reconocer lo más valioso y desechar aquello que, aunque recibió el reconocimiento de sus contemporáneos, no ha soportado el paso del tiempo.

4 En lo que se refiere a este punto, hemos observado cierta cautela ya que sabido es de todos que el transcurso del tiempo deja al descubierto la inconsistencia de algunos éxitos y, además, la experiencia nos muestra que existen obras excelentes que, por circunstancias desconocidas, no son premiadas nunca. Los premios consultados son los siguientes: 
han servido las Guias publicadas en los últimos años con el fin de facilitar un instrumento de trabajo a los profesionales del mundo de la educación, ${ }^{5}$ así como las reseñas acerca de las novedades publicadas en revistas dedicadas a la literatura infantil y juvenil.

Por último, no podemos obviar la presencia del gusto personal de quien confecciona la lista de obras elegidas. En algunos momentos, es de señalar una proclividad hacia ciertas obras y algunos autores, inclinación que obedece a esas preferencias que todos mostramos de cuando en vez, puesto que en el ámbito estético, el gusto, siempre justificado, es un valor nada desdeñable.

En la medida de lo posible, hemos intentado tener en cuenta las últimas aportaciones de la crítica preocupada por establecer un canon de la literatura infantil y juvenil españolas, canon siempre discutible en su composición y en su funcionalidad. ${ }^{6}$

Asimismo hemos optado por la estructuración final de las narraciones siguiendo el criterio de edad del receptor aunque, como expondremos en

Premios Nacionales de Literatura Infantil. Premios convocados por el Ministerio de Cultura desde el año 1978. Sólo se recogen en este estudio los concedidos «A la mejor labor de creación».

Libros de interés infantil y juvenil. Premio convocado por primera vez por la Dirección General de Promoción del Libro y de la Cinematografía en el año 1975 que recoge los mejores títulos publicados cada año en España. Este premio dejó de concederse en 1983.

Premio Lazarillo de Literatura Infantil. Premio creado por la Comisión de Literatura Infantil y Juvenil del INLE con el patrocinio del Ministerio de Información y Turismo y de Educación Nacional. Es el premio más antiguo de España ya que se convocó por primera vez en 1958. Desde esta fecha hasta nuestros días, ha sufrido en sus bases múltiples modificaciones.

Premio de Literatura Infantil de la CCEI. Premio otorgado por la Comisión Católica de la Infancia desde 1962.

Premio Andersen de Literatura Infantil. Galardón concedido cada dos años desde 1954 por el IBBY (International Board of Books for Young People).

5 Entre las obras de esta modalidad destacamos las siguientes: Guia de lecturas infantiles (1993), Guia de clásicos de la Literatura Infantil y Juvenil (1997), Guía de clásicos de la Literatura Infantil y Juvenil (desde 1950) (1998), de González; Guía de autores (1998), Guía de clásicos de la Literatura Infantil y Juvenil, 3: Libros ilustrados, cómic, poesía, teatro y bibliografia, de González (1999); Libros infantiles y juveniles para hacer buenos lectores (2000), de P. Barrena et al.; Entrequinientos. Una selección de lecturas para niños y jóvenes (2000); Leer antes de leer, de Durán (2002); Cien libros para un siglo, del Equipo Peonza (2004).

6 Cf. García Padrino, 2000: 67-91; Fernández, 2000a: 56-59. 
repetidas ocasiones, entendemos que esta selección no tiene valor de corpus y, por tanto, no se adapta estrictamente a los criterios de edad puesto que la recepción literaria no puede — ni debe — estar sujeta a restricciones cronológicas. Para fijar, siempre aproximadamente, la edad del receptor al que van dirigidas las obras nos hemos guiado por las indicaciones de las editoriales, en bastantes casos, y, en algunos, por la mera experiencia. Comprobaremos cómo el primer criterio en bastantes ocasiones es discutible puesto que la recepción puede ser mucho más amplia. En este sentido, no podemos olvidar que nos encontramos ante un tipo de literatura que va dirigida al receptor infantil siempre mediatizado por la figura del adulto que es quien, en última instancia, ofrece el libro al niño. La etapa en la que nos movemos es la comprendida entre los cinco y los doce años, momento, este último, en el que el lector comienza a acercarse a la literatura juvenil. Por último, hemos tomado como referencia la distribución por edades del currículo escolar («Anexo», pp. 245-248).

En el transcurso del estudio, se han tenido en cuenta tanto los aspectos textuales (autor textual, narrador, narratario y lector textual) como los paratextuales (ilustración, peritexto editorial, etc.), no con la finalidad de configurar estadísticas sino con el objeto de definir las características en vías de consolidación que, de algún modo, pueden marcar líneas incipientes en la innovación del discurso.

Dedicaremos, por tanto, las próximas páginas a reflexionar sobre las nuevas y las viejas formas de contar y sobre los nuevos y viejos contadores en el umbral del siglo XXI, con el ánimo de desentrañar cómo se construye el espacio poético del discurso narrativo infantil de los últimos años. Eso sí, acudiremos a la autoridad de Sherezade, a la experiencia de las abuelas — sin duda, las mejores narradoras - y a la protección de Aristóteles, sobre todo, de Aristóteles en la búsqueda de la frontera que separa la poiesis de la mimesis.

Terminando ya, obligado es reconocer el apoyo de quienes, directa e indirectamente, han posibilitado que este amasijo de ideas y de palabras se convirtiera en libro. A todos ellos, gracias, y muy especialmente a Cristina Tabernero, sin quien este libro, como tantos otros proyectos académicos y 
vitales, no hubiera sido posible; a Kurt Spang, director mi tesis doctoral, por la confianza que, en su día, depositó en mi trabajo; a M. Victoria Sotomayor, por la amable y generosa redacción del prólogo de este estudio; a José Domingo Dueñas, por sus atinadas observaciones; a Pilar Morterero, por el regalo que ha supuesto el apoyo incondicional a todas mis iniciativas; a "mis escritores e ilustradores aragoneses» —especialmente a Ana G. Lartitegui y a Sergio Lairla—, por recordarme que la labor de cada día no carece de sentido; a Prensas Universitarias de Zaragoza, por haber asumido la publicación de este trabajo.

Y a Víctor Juan, por haber querido compartir conmigo estas páginas mediante una crítica rigurosa, por acompañarme, como siempre, sin reservas y hasta el final, en este empeño, y por haber entendido, desde la complicidad, que Platero fuera un burrito odioso.

$\mathrm{Y}$ es que, en ocasiones, para «llamarnos como nos llamamos» son necesarios «anchos espacios y largos tiempos» salpicados por las personas cuyos nombres nos recuerdan. 


\section{CAPÍTULO 1 LITERATURA INFANTIL: APROXIMACIÓN AL ÁMBITO DE ESTUDIO}

\subsection{Para comenzar}

El concepto de literatura infantil posee una reducida tradición temporal, puesto que, tal como señalaba Cerrillo (1990: 11), «hace apenas medio siglo que hablamos de literatura infantil». Aun cuando en la actualidad, se viene aceptando con sorprendente unanimidad la identificación de esta práctica discursiva con una escritura de naturaleza estética, no siempre ha ocurrido así. Realmente antes de llegar al estadio en el que nos encontramos, se han producido varios debates teóricos que han versado en definitiva sobre la naturaleza del objeto de tal disciplina y que desembocaron en lo que se ha dado en llamar el boom de la literatura infantil de los años ochenta (cf. Fernández, 1994: 90).

La primera cuestión que siempre se ha abordado desde la perspectiva teórica ha sido la de la concepción de la literatura infantil ${ }^{1}$ como discurso de naturaleza estética.

1 De aquí en adelante utilizaremos el término de literatura infantil para referirnos a la disciplina que atañe al estudio del discurso literario infantil. Somos conocedores, no obstante, de la existencia en estos momentos de varios intentos de aquilatar los límites de la literatura juvenil con el fin de diferenciarla de las obras literarias dirigidas a los niños. Preguntas que marcaron los comienzos de la literatura infantil como jexiste la novela juvenil?, ¿cómo se diferencia de la literatura para adultos?, ¿qué temas son los que se presentan?, ¿cómo es el receptor al que va dirigida?, se plantean muy a menudo en artículos, conferencias 
Pocas veces un área o disciplina se han visto tan rodeadas de interrogantes como en la literatura infantil y juvenil (LIJ). Se cuestiona su definición, sus límites, sus relaciones con otros campos de la creación y del saber. Y, por si fuera poco, se cuestiona su misma legitimidad (Díaz-Plaja Taboada y Prats i Ripoll, 1998: 191).

Definir en qué consiste la literatura infantil ${ }^{2}$ es tarea harto complicada como lo es definir qué es la literatura sin adjetivos. No queremos caer en lo que con acierto señalaba J. García Padrino (1995: 53) citando a Baumgärtner:

quien se proponga escribir o hablar sobre literatura infantil se verá abocado a la curiosa situación de tener que explicar previamente cuál es en realidad el objeto que se va a tratar.

Desde los primeros momentos en que se comienza a hablar de literatura infantil, surgen las voces de aquellos que niegan la posibilidad plenamente artística de la escritura destinada a los niños. A este respecto, cabe destacar la conocida posición de Croce, quien no admite otra posibilidad estética y taxonómica que la de literatura sin adjetivos. Para el esteta napolitano, que se mueve, no lo olvidemos, dentro de los parámetros de las teorías del arte por el arte de corte neoidealista, crear arte para niños es subordinar la libre expresión y la libre visión a una finalidad espuria. Declaraciones como las que siguen han perjudicado en gran medida la consideración del carácter estético del discurso literario infantil:

basta la simple referencia a un público infantil como un dato fijo que hay que tener en cuenta para perturbar el trabajo artístico. El arte puro [...] requiere, para ser gustado, madurez de mente, ejercicio de atención y experiencia psicológica. El espléndido sol del arte no puede ser soportado por los ojos aún débiles del niño y el muchacho [...] para ellos son adecuados un cierto tipo de libros que tienen algo de artístico, pero contienen elementos extraestéticos,

y ciertas ponencias (cf. Teixidor, 1995; Cervera, 1995; Rodríguez Almodóvar, 1995; Moreno, 1995; Díaz-Plaja Taboada, 1998; Lluch, 2000; Dueñas y Tabernero, 2004). Bien es verdad que por ahora todo parece indicar que no se puede hablar de una literatura juvenil en general sino de una narrativa juvenil, puesto que los conceptos de poesía y teatro juveniles no acaban de configurarse.

2 Remitimos a la bibliografía que ha versado sobre la definición del concepto: BravoVillasante (1957, ed. de 1979: 7), Pastoriza de Echetbarne (1962: 3), Petrini (1963: 9), Townsend (1971a: 10), Soriano (1975: 185), Cresta de Leguizamón (1984: 28), Cervera (1984: 15; 1991), Rovira (1988), García Padrino (1988: 546), entre otros. 
curiosidad, aventuras, acciones audaces y guerreras [...]. En cualquier caso, si los niños pueden gustar de una obra de arte puro, ésta no habrá sido creada para ellos, sino para todos, y por ello no pertenecerá a la literatura para niños. Lo mismo ocurre con el arte popular, que o no es arte o no es popular (Croce, 1922: 119-120).

En la misma línea de pensamiento, Sánchez Ferlosio (1972: 11) era rotundo en sus afirmaciones cuando, después de comentar el lenguaje demasiado artificial y forzado del Pinocho de Collodi así como la excesiva «moralina» de la obra, se refería a la degradación a la que se somete el discurso literario si se supedita a la recepción infantil. Asimismo, Rico de Alba se expresaba de la siguiente forma:

La mal llamada literatura infantil es a la verdadera literatura lo que los castillos de arena que construimos en la playa para nuestros hijos es a la verdadera literatura (1986: 54).

Hasta los años setenta, el menosprecio del término «literatura infantil» ha sido casi general, dejando aparte, claro está, honrosas excepciones en lo que se refiere a nuestro país, entre las que cabe destacar a Bravo-Villasante (1985a), por la defensa que hizo de la tradición histórica de la literatura infantil como discurso literario, y a Cervera (1984, 1990, 1991a, 1991b, 1992, 1993, 1997), por sus apasionadas propuestas en aras de una dignificación teórica de la materia y de la adquisición del status teórico pertinente.

Durante bastante tiempo se mantuvo la polémica sobre el carácter literario de los textos dedicados a los niños y jóvenes. Incluso autores que negaron rotundamente la existencia de la literatura infantil ${ }^{3}$ reconocieron implícitamente que el destinatario infantil necesita un texto literario diferente del que se ofrece al adulto, puesto que su competencia lingüística y literaria no es la misma y su realidad vital difiere sobremanera de la de aquel. En definitiva, lo que aporta la polémica que versa sobre la existencia de la literatura infantil es la necesidad perentoria de redefinir desde el punto de vista teórico su especificidad.

Justo es reconocer que sobre la literatura infantil ha gravitado el peso de la función educativa (Shavit, 1986) dado el receptor al que va dirigido.

3 «El bajo nivel de sensibilidad artística de los mayores, es la condición del nivel degradado y degradante de lo que se le [sic] da a los niños» (Carandell, 1977: 23). 
Desde sus orígenes, los libros destinados a los niños se han definido por una constante: la finalidad moralizante que gobierna la estructura última de los textos. Aún hoy es difícil deslindar los conceptos de literatura y educación, como afirma García Padrino (1992b: 13):

El interés de mi intervención está orientado a ofrecer unas reflexiones sobre la necesidad, desde mi punto de vista, de asegurar ante todo el carácter independiente de la creación literaria y, al mismo tiempo, evitar la burda o la agobiante manipulación de la libre reacción del niño como receptor del mensaje literario, invocando para ello la justificación de la discutible supremacía de unos determinados valores educativos.

Es complicado desvincular la relación que existe entre literatura y pedagogía puesto que el propio origen de la literatura infantil ha estado unido, para algunos estudiosos, a la preocupación del adulto por utilizar las creaciones literarias al servicio de unos valores instructivos impuestos por la filosofía de cada época. Así, Petrini (1963: 41) habla de literatura educativa y atribuye a los pedagogos el haber hecho de «la literatura juvenil un problema vivo y actual». En opinión de este crítico, el escritor y el ilustrador de obras para jóvenes contrae con la sociedad una responsabilidad tanto estética como moral o intelectual. Para reforzar ese argumento histórico de la interdependencia que existe entre la literatura infantil y la educación, Petrini invocaba las razones que Sócrates expone a Adimanto en los diálogos que configuran el segundo libro de La República o el Estado, de Platón (1983, 16. a: 87):

[...] ¿No sabes que lo primero que se hace con los niños es contarles fábulas, y que aun cuando se encuentre en ellas a veces algo de verdadero, no son ordinariamente más que un tejido de mentiras? [...]

Tampoco ignoras que todo depende del comienzo, sobre todo tratándose de los niños, porque en esta edad su alma, aún tierna, recibe fácilmente todas las impresiones que se quieran.

—Nada más cierto. (Replica Adimanto) [...]

- ¿Llevaremos, por tanto, con paciencia que esté en manos de cualquiera contar indiferentemente toda clase de fábulas a los niños, y que su alma reciba impresiones contrarias en su mayor parte a las ideas que queremos que tengan en una edad más avanzada?

-Eso no debe consentirse.

-Comencemos, pues, ante todo por vigilar a los forjadores de fábulas. Escojamos las convenientes y desechemos las demás. En seguida comprometeremos a las nodrizas y a las madres a que entretengan a sus niños con los que escojan, y formen así sus almas con más cuidado aún que el que ponen en formar sus cuerpos. 
El texto citado podría servirnos para atribuir a la doctrina platónica el origen de la preocupación educativa por las creaciones literarias destinadas al niño. Se trata del clásico propósito horaciano del «instruir deleitando" que ha invadido las obras destinadas al niño desde sus comienzos - finales del XVIII, principios del XIX — hasta bien entrado el siglo XX. Habría que preguntarse si todavía hoy en parte de la creación literaria dirigida a nuestros niños, escondido bajo las apariencias de innovaciones formales, no subyace el lema horaciano.

Ya en el siglo XX, se ha convenido en reconocer que la especificidad de la literatura infantil radica en la presencia de un receptor-niño que condiciona el proceso de comunicación literaria.

Si en la literatura adulta el creador goza de independencia en relación con su receptor al que impone un código de lectura al que supone se adaptará el lector, en la literatura infantil sucede lo contrario: el receptor constituye un elemento condicionante e impone al creador adaptación y modificaciones... (Bortolussi, 1985: 132).

El acto de comunicación que supone la literatura infantil viene marcado específicamente por la relación que se establece entre un emisor-adulto y un receptor-niño con recursos y medios distintos.

De todos modos no hay que ir demasiado lejos en esa adecuación del emisor y su mensaje al lector, pues esa misma especificidad intencionada del mensaje dedicado al niño engendró un carácter de marginación de tales obras, respecto a la literatura para adultos (cf. García de Enterría, 1983: 11).

García Padrino (1990: 86) insistió en esta idea y así la asunción del carácter específico del niño como destinatario ha provocado que, desde sus orígenes, la literatura infantil esté teñida del «instruir deleitando» horaciano. A pesar de las conquistas de la fantasía romántica o de la «nonsense literature», a pesar de los hallazgos de la ciencia-ficción de Verne (1828-1905) o de las aventuras narradas por Stevenson (18501894), la producción literaria dedicada a los niños durante el siglo XX no se ve libre de los condicionamientos pragmáticos derivados de la rígida intencionalidad didáctica de muchos textos. En este sentido, Rodríguez Almodóvar (1989: 11), expone la persistencia de la manipulación moralizante habida en la literatura infantil al describir las intencionadas apro- 
piaciones que los «moralistas burgueses» hicieron de los cuentos de tradición oral:

En pocas actividades como sobre ésta habrá habido más apropiaciones. Y de modo particular las de los moralistas burgueses que desde mediados del siglo XIX, sobre todo, han cercenado, silenciado y modificado a placer lo que la sabiduría popular ha ido acumulando pacientemente a lo largo de los siglos. [...] si nos atenemos al repertorio mutilado y banalizado que comercializan las multinacionales de la narrativa infantil.

Lógicamente, cualquier didactismo soterrado bajo los artificios de un supuesto lenguaje estético encubre una desconfianza en las propias posibilidades de la creación estética e implica un menosprecio de la competencia del destinatario para generar sus propios significados. De otra parte, bien es verdad, como mencionábamos más arriba, que se contempla una necesidad de adoctrinar al destinatario de este discurso por su condición de individuo en formación.

Durante los últimos años del siglo XX, hemos asistido a una innegable evolución temática y a una mayor apertura ideológica en la producción de los libros infantiles, sin embargo, la literatura infantil actual está presentando un uniformismo ideológico alarmante, con la exhibición de problemas descontextualizados y la consiguiente dispersión de las responsabilidades. Temas como la preocupación por el medio ambiente están invadiendo la producción infantil hasta llegar al hastío. Sigue existiendo una fuerte y clara obsesión didáctica, tal como señalaba - casi premonitoriamente- Polanco (1990: 22) cuando se hacía eco de la «actitud paternalista y moralizante» de los autores.

Asimismo, hace no mucho el Instituto Cervantes virtual ha consagrado a estos asuntos un monográfico titulado "¿Qué pintan los cuentos?» en el que se refleja la preocupación por un discurso cada vez más dependiente del ámbito escolar y, por tanto, más ligado a un didactismo que lesiona gravemente la calidad de los discursos que aparecen en el mercado.

\subsection{El didactismo en el discurso literario infantil y juvenil}

Dado el receptor al que el discurso literario infantil se dirige, la función educativa y, por ende, los valores morales que allí se defienden han 
constituido uno de los puntos de referencia a la hora de enjuiciar la calidad de los libros infantiles. De este modo, parece que existe una necesidad de revisar y controlar los mensajes de los libros que aparecen en el mercado editorial.

Colomer (2001: 11-13) expone cómo se ha ido desarrollando este aspecto en los distintos discursos y atribuye la insistencia en el referente didáctico a la contemplación de la literatura como agente socializador y a la importancia que los mediadores confieren a la función educativa en aras de la consagración de la calidad de los libros. Ya en sus comienzos, en sus largos principios, la literatura infantil tuvo que luchar contra el didactismo que invadía los textos y reivindicar el poder educativo de la fantasía para asegurar su existencia. Así Bettelheim logró recuperar la validez de los textos folclóricos, aunque luego en los años ochenta se iniciara una revisión de los valores morales que aparecían reflejados en este tipo de obras. Así, tal como señala Colomer (2001: 12) se plantea como prioridad el análisis ideológico de las obras infantiles.

En el ámbito de la creación, se decidió, pues, invertir los estereotipos tradicionales y caminar hacia lo políticamente correcto. Comenzaron a aparecer, por tanto, en las obras personajes que sustentaban valores educativos y morales propios de la sociedad que los generaba. La inversión de los estereotipos tradicionales, los nuevos modelos de comportamiento acordes con una sociedad más avanzada y progresista constituyen notas características de cierto tipo de creación de las décadas de los ochenta y de los noventa, discursos trivializados por Garner:

Érase una vez una persona de corta edad llamada Caperucita Roja que vivía con su madre en la linde de un bosque. Un día, su madre le pidió que llevase una cesta con fruta fresca y agua mineral a casa de su abuela, pero no porque lo considerara una labor propia de mujeres, atención, sino porque ello representaba un acto generoso que contribuía a afianzar la sensación de comunidad (Cuentos politicamente correctos: 15).

Muy pronto la crítica entendió que las obras podían convertirse en verdaderos panfletos ideológicos por su excesiva supeditación al contenido del mensaje. No obstante, la función educativa de los textos continúa siendo una de las claves en la consideración del discurso literario infantil. Dicha importancia se debe, entre otras razones, a la incorporación de este tipo de texto a la escuela y al mercado que de ella depende. Uno de los mediadores 
más cualificados en el acto de comunicación literario que atañe al discurso que estamos trabajando es, sin ningún lugar a dudas, el maestro. Este mediador suele vincular los términos de lectura y trabajo, de tal modo que no resulta extraño oír que los libros se "trabajan", no se leen, pues, no se disfrutan sino que sirven como pretexto para estudiar otro tipo de valores.

No hace demasiado tiempo, por ejemplo, han aparecido en el mercado obras como Cuentos para contar en minuto y medio, de Bermejo y Gallardo, o Cuentos para soñar, de varios autores, a los que en el último año se han unido Cuentos sólo para niños y Cuentos sólo para niñas. En ellos se prioriza la enseñanza de valores y la adaptación a necesidades extraliterarias sobre cualquier cualidad puramente literaria y ficcional.

A pesar de la insistencia en el aspecto educativo y formativo del discurso literario infantil, y aunque los autores y editores potencien esta línea de creación, adivinamos en el mercado un tipo de discurso que rompe con las virtudes formativas y se adentra en el camino de la experimentación basada, sobre todo, en la confianza en la competencia del lector. Valgan como ejemplos de lo que acabamos de exponer obras como Mamá fue pequeña antes de ser mayor, de Larrondo y Lamartine, o La carta de la señora González, de Lairla y Lartitegui. En este tipo de obras, aparecen elementos no verbales que pasan a desempeñar un papel fundamental en la construcción de significados.

\subsection{Nuevos caminos en la creación}

Del panorama que se adivina hoy en lo que respecta a la creación en el discurso literario infantil (Fernández, 2004a: 50), dos vías se apartan del didactismo - explícito o soterrado- que antes hemos mencionado. Una de ellas se adentra por el camino de la experimentación a través de la combinación de imagen y texto. La ilustración pasa a ser en este tipo de obras un código que construye significados junto al verbal, de tal modo que sin la intervención del mismo, el discurso no puede ser interpretado. Esto implica que el lector debe integrar los dos códigos en sus estrategias de recepción. Muestras de esta corriente de creación pueden constituir obras como Mamá fue pequeña antes de ser mayor, de Larrondo y Lamartine o El libro que tenía un agujero, de Domitille y Héron; o ¡Papá!, de Corentin, álbumes que analizaremos en el capítulo siguiente. 
La segunda vía está definida por obras que, además de incorporar la imagen como elemento característico del discurso, proponen un texto más abierto con un narrador menos fiable y, por ende, menos direccionista, un narrador que, en ocasiones, desaparece para construir un lector generador de significados. El humor en estas creaciones es una constante y lo que todavía es más novedoso, la presencia de la ironía como recurso muestra posibilidades olvidadas. Un ejemplo de todo lo que acabamos de exponer se encuentra en las obras de Nesquens:

¿De qué recursos se sirve para lograr ese surrealismo tan humorístico y sorpresivo en sus relatos? De no ponerle puertas al campo. Y de dar siempre un paso más. Un niño tiene derecho a imaginar que es factible que llueva a mares y que un barco pesquero entre en una plaza de toros, que su vecino sea un agente secreto, que en su jardín esté enterrado un tesoro pirata, que los conejos se pesquen... (Nesquens, 2000: 94).

El relato Mi sobrina, que forma parte del libro Diecisiete cuentos y dos pingüinos, constituye uno de los mejores ejemplos de este tipo de realización. En él un narrador en primera persona cuenta la historia de dos cucharas que no consiguen salir del cajón porque las personas de la casa a la que pertenecen comen muchas ensaladas. Sin embargo, un día consiguen salir al campo:

$\mathrm{Y}$ todos fueron al campo a pasar el día. A ver hormigas y moscas y vacas y latas de aceite abandonadas. Todos juntos en el mismo bolso. Las cucharas, los tenedores, los cuchillos, las cucharillas, los botellines de cerveza, las latas de atún, de mejillones, de lentejas guisadas. Eso fue lo malo: que fueron todos menos los periquitos que se quedaron en la jaula. Y el abrelatas que se quedó en el cajón (Nesquens, 2000: 48).

Merece la pena analizar el relato desde la perspectiva de la presencia del lector y las pistas que el propio texto ofrece en la construcción de significados.

1. Tengo una sobrina...

2. Me exigió que le contase un cuento de cucharas...

3. En aquella casa había dos cucharas...

Las cucharas estaban en el cajón...

Los periquitos estaban en la jaula.

Y el abrelatas en el cajón. 
4. A las dos cucharas les hubiera encantado ir al campo...

5. Pero un domingo, recién comenzado el verano, la dueña de la casa cogió las cucharas...Y todos fueron al campo a pasar el día.

6. Eso fue lo malo: que fueron todos menos los periquitos, que se quedaron en la jaula. Y el abrelatas, que se quedó en el cajón.

Como se puede comprobar, se trata de un tipo de discurso muy alejado de los modelos psicoliterarios, que aboga por una línea humorística desprovista de cualquier tipo de didactismo explícito.

El panorama actual del discurso literario infantil camina por senderos muy diferenciados. En todo caso, se vislumbra una mayor apertura a corrientes de mayor experimentalidad, que dan cabida al humor y que intentan construir, en definitiva, un lector cooperativo. En este sentido, es de destacar el álbum como uno de los subgéneros más novedosos y arriesgados ya que la combinación entre texto e imagen se adecua a un nuevo lector, el del siglo XXI, acostumbrado más que ningún otro a la interpretación del lenguaje audiovisual. ${ }^{4}$ Nuevas formas de narrar obedecen también a un discurso que exige paradigmas críticos nuevos e interdisciplinares.

En lo que respecta a los temas, es necesario contemplar qué se les transmite a los niños y cuáles son los valores que se incorporan al discurso literario. Así los mediadores — al menos, parte de ellos- buscan discursos frescos, rupturistas, que desarrollen nuevas formas de contar dirigidas a un receptor también distinto. La literatura infantil y juvenil —el corpus seleccionado - debe construir un camino de aprendizaje en la formación de lectores competentes, no sólo en la pura comprensión sino en la interpretación. Para ello es necesario valorar los libros infantiles y juveniles desde parámetros no exclusivamente temáticos y, por qué no decirlo, demasiado apegados al currículum escolar y a sus posibilidades didácticas (cf. Colomer, 2002c).

\subsection{El desarrollo de los estudios sobre literatura infantil}

Puesto que estamos hablando de un modo literario relativamente reciente, es necesario señalar que la necesidad de reflexionar sobre los

4 Apuestas de editoriales como Kalandraka y Corimbo, entre otras, certifican este tipo de tendencia. 
libros para niños y para jóvenes, aunque estos existieran como fenómeno cultural desde finales del siglo XVIII, surge en el período de entreguerras del siglo XX coincidiendo con el desarrollo editorial y con la creciente preocupación por la lectura infantil, dados los avances realizados por aquel entonces en el campo educativo.

Aunque la escuela tardó en incorporarse a una concepción moderna de la lectura como un acto libre de los ciudadanos distanciado de la preocupación formativa y cada vez más próximo al deleite, se contempló ya en estos momentos la necesidad de establecer unos criterios para seleccionar qué libros ofrecer a los jóvenes. De esta preocupación nacen los primeros estudios de literatura infantil enfocados desde una perspectiva moderna como es la que corresponde al personal que en aquellos tiempos trabajaba en el fomento de la lectura al margen de la escuela ${ }^{5}$ (cf. Soriano, 1995). Paralelamente fueron apareciendo los primeros estudios sobre literatura infantil y juvenil de cierta relevancia, tales como los de Cone Bryant (1910), Lahy-Hollebecque (1928) o de Hazard (1977).

De Gran Bretaña proceden estudios de bibliotecarios tan reconocidos como Spink (1990). En Francia es de destacar la biblioteca de la Joie par les livres de Clamart creada bajo la dirección de Patte (1987). En este orden, Italia ha generado estudios como los dirigidos por Parmegiani (1985).

Asimismo, es de destacar lo que supuso la creación del International Board of Books for Young People (IBBY), fundado en 1953 por Jella Lepman en Zúrich. En 1956, en el seno de esta institución, se convocó por

5 Colomer (1998: 23-31) expone sucintamente cuál fue la influencia de la labor de las bibliotecas infantiles británicas, norteamericanas, francesas y del norte de Europa que se fueron creando en aquel momento. En principio, su tarea consistió en plantear la necesidad de seleccionar las lecturas que se les iba a ofrecer a los niños y jóvenes. Esta reflexión provocó, a su vez, la aparición de numerosas iniciativas de difusión de los libros infantiles, algunas de las cuales cuajaron en la fundación de bibliotecas infantiles como la de Bruselas en 1920 o L'Heure Joyeuse en París (1924). Después de la segunda guerra mundial se sigue reflexionando sobre el valor de los libros y de las bibliotecas públicas. A este respecto hay que señalar la labor de la periodista judía alemana de nacionalidad americana Jella Lepman que creó la Internationale Jugendbibliothek de Múnich en 1949 y la American Library Association, biblioteca que actualmente constituye el mayor centro de documentación sobre literatura infantil y juvenil. 
primera vez el Premio Andersen que constituye, aun hoy en día, el galardón de mayor prestigio en el ámbito que nos ocupa. ${ }^{6}$

\subsubsection{Los estudios históricos}

Una de las primeras preocupaciones, después de intentar establecer cuál era el corpus de la literatura infantil, fue la de exponer cronológicamente el desarrollo de la creación literaria para niños. Surgieron así los primeros trabajos de carácter histórico con el ánimo de ordenar la producción en esta área. Paulatinamente fueron creándose bancos de datos y centros de documentación para facilitar una tarea que se consideraba esencial. El estado actual de los estudios sobre la evolución cronólógica, como señala Colomer (1998: 32), varía según lo consolidada que esté la edición en los diferentes países. Así, la existencia de obras de referencia en Gran Bretaña o en los países nórdicos es muy superior al número de obras que podemos encontrar en España.

Historiar la literatura infantil constituye una tarea muy complicada, ya que hay que tener en cuenta que toda obra es hija del contexto en el que nace. Contextualizar una creación es, pues, necesario para comprenderla en todas sus dimensiones. En el caso de la literatura infantil nos encontramos con obras que sólo adquieren sentido desde el conocimiento del receptor al que primeramente se dirigieron. No olvidemos que, como señala Bortolussi (1985: 20), toda obra literaria infantil refleja una peculiar visión de la infancia que obedece a los principios filosóficos que sustentan la época en cuestión. Todo lo que acabamos de exponer dificulta sobremanera el acercamiento del lector infantil actual a ciertas obras literarias no exentas de calidad, pero que sólo pueden partir en su recepción de una contextualización adecuada para la que el niño no está preparado, puesto que, en principio, los lectores abordan las creaciones en un encuentro despojado de contexto y a partir de su progresiva adquisición de competencia lectora. La vigencia de los clásicos concebidos como obras que no han agotado su capacidad de comunicación a lo largo del tiempo es un aspecto que suele ser discutido en estudios de la naturaleza que aborda-

6 Este premio se concede cada dos años a un autor y a un ilustrador por el conjunto de su obra. Simultáneamente se proclama una lista de honor en la que figuran un libro infantil por país. La versión española de este premio de carácter mundial se encuentra en el Premio Lazarillo concedido también a un autor y a un ilustrador. 
mos. ${ }^{7}$ En esta línea es de destacar la obra del grupo Peonza Cien libros para un siglo, que ha iniciado cada una de las décadas con una contextualización sociohistórica que, de algún modo, contiene las claves de acceso a cada uno de los textos que después se presenta.

Por otra parte, antes de establecer el corpus de las obras que pueden formar parte de una historia de la literatura infantil, es necesario reseñar que hay producciones que no nacieron con la intención de dirigirse al receptor infantil pero que, por causas muy distintas, han pasado a formar parte de las colecciones caracterizadas como infantiles y juveniles, puesto que los lectores así lo han solicitado. ${ }^{8}$ La modificación del destinatario se ha producido, en el caso de la literatura oral y en el de la de adultos, antes de que empezara a considerarse la literatura infantil como un modo con entidad propia.

Por otra parte, no es extraordinario en nuestros tiempos el hecho de que aparezcan publicados con el formato propio del álbum creaciones que, en realidad, no están dirigidas exclusivamente a un público infantil, por lo que depende del criterio del selector que figuren o no en una historia del género. Se trata de libros que conceden una gran importancia al formato y al elemento plástico como en el caso, por poner un ejemplo, de Hadas malvadas (1998), de Steer y Ludlow. Una de las tendencias que se adivina en el mercado, partiendo de los presupuestos que acabamos de mencionar, es la publicación de clásicos ilustrados nuevamente, es decir, reinterpretados. Desde Alicia en el país de las maravillas, ilustrada por Oxenbury, hasta La isla del tesoro, ilustrada por Junceda, o La metamorfosis de Kafka por Scafati, pasando por la ilustración de Las mil y una noches a cargo de Serrano, Ranucci, Arguilé, Riera y Odriozola, pueden servir como guía de lo que se está produciendo en la oferta editorial actual.

7 T. Colomer (1998: 33) hace referencia en este sentido a los libros anglosajones de la época victoriana cuyas claves de interpretación se encuentran en las fórmulas tipificadas a las que obedecen estos textos que son difícilmente interpretables por el receptor de nuestros días.

8 Cf. Green, 1946 y 1962. A este autor se le debe la distinción entre «libros escritos para niños» $\mathrm{y}$ «libros que han sido adoptados por los niños», además de la también clásica diferenciación en los estudios de literatura infantil posteriores entre «destinatarios de los libros» $\mathrm{y}$ «receptores de los libros». Estas distinciones han sido incorporadas en obras como los diccionarios de Carpenter y Pritchard (1984) o en estudios que tratan de fundamentar el estatus teórico que corresponde a la literatura infantil como los de López Tamés (1985), Cervera (1991a) o Sánchez Corral (1995). 
Por otra parte, los límites de edad propuestos en la recepción dejan de ser valores absolutos, si alguna vez lo fueron, y se convierten en aproximaciones relativas. De este modo, libros dirigidos, en un principio, al público infantil y juvenil son demandados por el público adulto. Tal es el caso de Manolito Gafotas, en España, y de Harry Potter en Gran Bretaña. Así rezaba un artículo periodístico que trataba sobre la última creación citada:

Hay otro factor que ha contribuido a crear el fenómeno Harry Potter entre los británicos. Los padres de los niños lectores han acabado ellos mismos devorando los libros con fruición. Tal es la demanda que la editorial ha decidido imprimir unas tapas distintas para que los mayores puedan leer en público, sin ruborizarse, las mismas historias que sus hijos (Argos, «El auge de la literatura infantil también llega a casa», El País, 31 de octubre de 1999, 39).

Desde principios de siglo hasta los años cincuenta aproximadamente, los panoramas históricos que versan sobre literatura infantil se limitaron a ofrecer listas desordenadas en las que reinaba la presencia de valoraciones intuitivas en detrimento de criterios más rigurosos. ${ }^{10}$ Así, Calleja (1989: 20) expone que «la historia de los libros infantiles consistirá en largos repertorios caóticos o en tímidas consideraciones intuitivas».

A partir de los años sesenta, se empiezan a publicar historias universales de la literatura infantil que han acabado configurando y estabilizando relativamente el corpus, siempre discutible como hemos señalado anteriormente, del que se parte en nuestros días. ${ }^{11}$

9 Nos referimos a un personaje, Harry Potter, creado por J. K. Rowling, de gran éxito en los últimos tiempos en los países anglosajones. Los tres primeros libros escritos sobre este niño aprendiz de mago han supuesto unas ventas de muchos millones de ejemplares en Estados Unidos desde 1998 hasta la fecha en la que nos encontramos. En España contamos con las siguientes traducciones: Harry Potter y la piedra filosofal, Barcelona, Emecé, 1998; Harry Potter y la cámara secreta, Barcelona, Emecé, 1999; Harry Potter y el prisionero de Azkabán, Barcelona, Salamandra, 2000; Harry Potter y el cáliz de fuego, Barcelona, Salamandra, 2001, y Harry Potter y la orden del Fénix, Barcelona, Salamandra, 2004.

10 Cf. Salway, 1986; Hunt, 1990.

11 Son dignos de mención, porque han supuesto un obligado punto de referencia en las obras posteriores, los estudios de Hürlimann (1968) y de Escarpit (1986). Por otra parte, existen trabajos de cierta relevancia que no han sido traducidos a nuestra lengua como los de Trigon (1950), en el ámbito francés, o el de Green (1946 y 1962), en Gran Bretaña. En España contamos con la ingente obra de Bravo-Villasante (1959, 1971, 1977, 1979-1993, 1985a, 1985b, 1988 y 1989), quien intentó abarcar todo lo publicado dentro 
En los años ochenta, centrándonos en nuestro país, se comenzaron a publicar estudios de carácter histórico referidos a un sólo género ${ }^{12} \mathrm{o}$ aspecto (cf. Gómez del Manzano, 1987), o a un tiempo más acotado. ${ }^{13}$ En lo que respecta a las publicaciones sobre géneros, es necesario destacar la escasez de estudios sobre poesía y teatro. Los trabajos sobre poesía versan principalmente sobre la tradición oral, ${ }^{14}$ en tanto que los de teatro, salvo alguna excepción como la que constituye el estudio de Tejerina (1993), insisten en el aspecto de la dramatización en detrimento del estudio de los textos teatrales (cf. Tejerina, 1994).

En el área anglosajona se están publicando estudios que tienden a revisar lo que hasta ahora se ha realizado cuestionando los parámetros que han servido de referencia para elaborar el material histórico (cf. Richards, 1989). Con todo, en lo que respecta a los estudios históricos, es necesario contemplar la evolución de los textos analizando el contexto social, económico y pedagógico que los genera. Sin ánimo de parecer deterministas, pensamos que en literatura infantil el análisis del contexto en el que nace la obra literaria es, si cabe, más esclarecedor que en la literatura para adultos. De este modo lo contempla Lluch (2003) cuando en el análisis pragmático se refiere a contextos e ideologías que funcionan como punto de partida.

\subsubsection{Otras perspectivas}

Paulatinamente los estudios sobre literatura infantil, de carácter eminentemente interdisciplinar, han ido caminando, en los últimos años,

y fuera de España. Actualmente son muy discutibles las apreciaciones de esta autora, puesto que ella, como era de esperar del tiempo en el que publica sus libros, se preocupa sobremanera por la moralidad de las creaciones que analiza y por la finalidad educativa de las mismas. No hacemos referencia en el texto a la labor de estudiosos que se han centrado en clarificar el panorama que ofrece la literatura infantil publicada en otras lenguas reconocidas oficialmente en nuestro país, como es el caso de la literatura infantil catalana que posee una tradición digna de reseñar (cf. Rovira, 1976 y 1988).

12 Cf. Vázquez, 1963; Mendoza, 1980; Cervera, 1982; Cerrillo y García Padrino, 1990; Cubells, 1990.

13 Cf. Cendán Pazos, 1986; Cervera, 1991c; Colomer, 1991, 1992a, 1992b y 1992c, García Padrino, 1992c. Hemos reseñado los estudios de mayor calado, sin ánimo de ser exhaustivos. Publicaciones de este tipo, no obstante, son frecuentes en revistas especializadas como CLIJ, Lluc, Peonza, Cuadernos de Pedagogía, Boletín de Amigos del Libro, etc.

14 Cf. Janer Manila, 1982; Pelegrín, 1984, 1994 y 1996. 
hacia la contemplación de lo que se considera el elemento diferenciador de esta literatura frente a la literatura para adultos: el receptor. Antes de llegar a este punto, la teoría de la literatura infantil se ha nutrido de las aportaciones realizadas aisladamente desde los distintos campos del saber. El psicoanálisis y la psicología cognitiva han incidido en el estudio de la infancia y, por ende, del sujeto receptor.

El desarrollo del psicoanálisis en el siglo XX ha condicionado, sin lugar a dudas, las ideas convencionales sobre la infancia. La obra de Bettelheim (1976) se publica en un momento en el que se denostaban los cuentos de hadas por su falta de compromiso con la realidad, además de presentar dosis de violencia no recomendables para el receptor infantil, comportamientos sociales moralmente reprobables y defender la prolongación del orden establecido. Ejemplo de lo que acabamos de exponer es la publicación en 1951 de Nos livres d'enfants ont menti de Brauner. Por supuesto, esto se produce en el contexto de unos años en que, después de la segunda guerra mundial, se considera que no es tiempo para la fantasía. ${ }^{15}$

La obra de Bettelheim (1976) supuso una reivindicación del valor de los cuentos de hadas en la educación. Parte este autor del supuesto de que al niño hay que suministrarle elementos con los que resuelva la confusión que reina en su interior. La defensa que Bettelheim realiza del cuento de hadas vinculado al receptor infantil ha sido continuada hasta nuestros días en estudios paradigmáticos como los de Rodríguez Almodóvar (1982 y 1989), Pelegrín (1982 y 1984), Medina (1990) o Pisanty (1995). ${ }^{16}$

Bettelheim además reconoció en los cuentos un valor terapéutico que él mismo comprobó al trabajar con niños provenientes de los campos de concentración nazis. Este aspecto suscitó críticas premonitorias como la de Patte (1987), quien advirtió del peligro que entrañaba ampliar la concepción

15 Jan (1977, reed. de 1969), comentando la experiencia de los álbumes de Père Castor, constató su desconfianza en el valor educativo de los libros escritos expresamente para los niños, en primer lugar, porque a los receptores no les entusiasmaban y, en segundo lugar, por el hecho de que se reflejara en ellos cómo debía ser la vida, no cómo era realmente.

16 No olvidamos la trascendencia del estudio de Bühler (1918) sobre los cuentos de Grimm. Bühler señala en este trabajo ya clásico cuáles son los aspectos literarios del folclore que se adecuan a la mente infantil: pocos personajes muy tipificados, motivaciones de las acciones determinadas por hechos externos y moral maniquea y dogmática. 
terapéutica a la totalidad de la literatura infantil. No iba descaminada en su apreciación, puesto que en las dos últimas décadas el mercado editorial está ofreciendo colecciones de libros adecuados para resolver problemas concretos. ${ }^{17}$ Ya Patte (1987: 54) avisó de lo empobrecedor que podía ser el caminar por esta vía a la que denomina «biblioterapia».

Desde la perspectiva social, Jean (1988: 240) reivindica la presencia de la literatura escrita además de la tradicional.

Así, Bettelheim sentó las bases de lo que se denominó en los años setenta nueva fantasía o cuentos de hadas modernos (cf. Soriano, 1995), cuentos que sustituían los elementos maravillosos tradicionales por auxiliares más vinculados a la realidad del lector infantil. En este sentido, fue Rodari (1976) quien popularizó la nueva fórmula y construyó asimismo el bloque teórico más sólido de lo que supone la reivindicación de la presencia de la fantasía en la infancia. ${ }^{18}$ De este modo, la llamada literatura antiautoritaria que se concretó en la desmitificación de los valores y personajes propios del cuento tradicional pobló de princesas activas, monstruos pacíficos y pruebas actualizadas las obras que se ofrecían a los niños en aquellos momentos. Y, como suele ocurrir, el abuso de esta concepción acabó saturando la oferta por la excesiva moralina de gran parte de las obras así concebidas.

La psicología cognitiva, en su interés por el estudio de la construcción del conocimiento y el aprendizaje, ha influido en el desarrollo de la literatura infantil, no tanto en el campo de la creación como en lo que se refiere a la investigación. Los estudios de Piaget (1971) sobre los estadios del desarrollo intelectual de los niños han repercutido en la valoración y en la producción de los libros infantiles. ${ }^{19}$ El desarrollo de las franjas de edad en las recomendaciones de los libros se lo debemos, en gran medida, a los estudios del psicólogo mencionado. No obstante, investigaciones poste-

17 Estamos refiriéndonos a lo que se conoce con el nombre de psicoliteratura, literatura intrapsíquica o libros de familia (cf. Gasol y Lisson, 1989; Gómez Cerdá, 1990; Lage Fernández, 1991 y 1995). Un nuevo concepto, el de libros de autoayuda (cf. Fernández, 1999: 8), está apareciendo en el ámbito de la literatura infantil. Con el nombre de libros de autoayuda se hace referencia a obras que versan sobre problemas concretos que previsiblemente el niño se encontrará en su desarrollo personal.

18 Held (1981) elaboró el estudio más conocido en España acerca del papel que desempeña la fantasía en las creaciones literarias para niños.

19 Cf. Applebee, 1978; Tucker, 1981. 
riores $^{20}$ han puesto de relieve que los niños son capaces de acceder a historias más complicadas que las que propone la teoría piagetiana. $Y$ es que la recepción literaria no es fácil de concretar en lo que a edad se refiere, puesto que la competencia lectora se distingue de la competencia literaria en el momento en que nos adentramos en los «límites de la interpretación» (Eco, 1998). Desde estos presupuestos, se explica, en ocasiones, las posibilidades que se abren en el mundo de las sugerencias, cerradas asimismo en el ámbito de la comprensión.

Posteriormente, la psicología cognitiva insistió en que el niño se apoya en las situaciones sociales para construir su comprensión del mundo (cf. Bruner, 1988), tal como lo señaló Vigotski (1978). De este modo, el constructivismo social $^{21}$ se ha orientado en la última década del siglo XX hacia el estudio de la lectura como proceso de comprensión del texto y hacia el estudio de las formas narrativas del discurso como un sistema cultural extraordinariamente potente para dar forma a la experiencia, como señala Colomer (1998: 72).

A través de esta experiencia [refiriéndose a los cuentos escuchados en la primera infancia], el niño empieza a descubrir la potencialidad simbólica del lenguaje: su poder para crear mundos posibles o imaginarios por medio de la palabra (Wells, 1988: 192).

También se ha estudiado el proceso de comprensión de las narraciones, partiendo de lo investigado por la "gramática de la narración» en los años setenta (cf. Applebee, 1978).

La respuesta afectiva del lector y su contribución en la generación de los mensajes es otra de las líneas que en estos últimos años se ha desarrollado (Monsenthal, 1987; Corcoran y Evans, 1987; Durán y Ros, 1995; Colomer, 1995). En lo que concierne a la participación del lector en el discurso, debemos mencionar las obras de autores como Petrini (1963), Abbadie-Clerc (1977), Held (1981), Escarpit (1986), Nobile (1992) y Gárate (1994), entre otros.

Como ocurre en la literatura para adultos, el interés por la lectura como hábito social ha generado una gran cantidad de informes siguien-

20 Cf. Donaldson, 1979; Bunbury y Tabber, 1989.

21 Cf. Brufee, 1984 y 1986. 
do la línea marcada por documentos, pioneros en este campo, como es el de Escarpit (1986). Los datos procedentes de la mera estadística ${ }^{22}$ pueden $^{2}$ desvelar en qué medida los niños procedentes de diferentes clases sociales se acercan al hecho literario y cómo hay que plantear las actividades de promoción de la lectura ${ }^{23}$ para ampliar el número de lectores. A este tipo de estudios, que suele basarse en la realización de cuestionarios, corresponde una de las líneas más comentadas en los últimos años. Me referiré en este trabajo en más de una ocasión a estos datos que no hacen más que obedecer a la necesidad de tener en cuenta la opinión del lector con la finalidad de descubrir las claves de generación del discurso que nos ocupa.

\footnotetext{
No hay duda de que tenemos que progresar enormemente en saber qué gusta a los niños y cómo podemos hacerles evolucionar. Pero para ello hay que escucharles hablando de libros, verles formando y explicitando su opinión y saber también qué opinan sus padres y maestros (Colomer, 2002: 14).
}

Quedan todavía más vías por explorar. En este sentido, podrían ser citados los estudios de Cerdá (1978 y 1985), Colomer (1991), Machado (1995), Petit (1999) o Montes (1999), en lo que se refiere al análisis de los modelos educativos; o los de Dearden (1994), Turin (1995), Zipes (1986), Orquín (1989), Colomer (1994), Lurie (1998) y Obiols (1998), en lo que respecta al estudio de tópicos específicos como la interculturalidad o el feminismo.

\subsubsection{Por fin, la perspectiva literaria}

Dada la falta de tradición de la literatura infantil y la cantidad de tinta que se ha vertido en defender el concepto y la existencia de la literatura infantil, los estudios que han intentado definir las características literarias de la producción textual destinada a los niños han sido escasos y, en su mayor parte, se han visto desprovistos de un marco teórico

22 Nos referimos a informes elaborados por instituciones vinculadas al mundo del libro infantil como delegaciones del IBBY, fundaciones como la de G. Sánchez Ruipérez o el propio Ministerio de Cultura. Cf. asimismo: Ministerio de Cultura (1978) y Centro del Libro y de la Lectura (1990), La lectura en España. Informe 2002. Federación de Gremios de Editores.

23 Cf. Cerrillo y García Padrino, 1996; Sarto, 1985 y 1998; Sarto y Careaga, 1999; Abril, 2000. 
de referencia aplicable al discurso literario infantil. Si frecuentes han sido hasta ahora las voces que han solicitado la presencia del marco teórico mencionado ${ }^{24}$, la llegada del año 2000 que ha suscitado, como en otros ámbitos de la actividad humana, la necesidad de reflexionar y recapitular, ha confirmado la existencia de este vacío. La constatación, a través de datos publicados por diversas editoriales e instituciones (Fernández, 1999: 8; Chapa, 2000: 103; Fernández, 2004a), de que en España cada vez se publica más, sin discriminación de calidad, y se lee menos, es decir, la oferta es excesiva para la demanda existente, implica que algo está fallando en lo que se refiere al entorno de la literatura infantil.

De este modo, no estaría de más traer a estas páginas lo que pueden aportar los datos extraídos de los diferentes informes publicados sobre el mercado del libro en España y sobre los hábitos lectores de los españoles. ${ }^{25}$ Tras el análisis de los mismos, Marchamalo (2004: 31-32) destaca las siguientes conclusiones dignas de comentario. En primer lugar, se desprende de las encuestas que sirven de sustento a cada uno de los estudios, que casi la mitad de la literatura que se produce en España está dirigida al mercado infantil y juvenil, es decir al $19 \%$ de la población, según rezan los datos que obran en poder de la Federación de Gremios de Editores de España (2002). Los datos fluctúan, no obstante, ya que Fernández (2004a: 35) habla en el mismo anuario de que la producción literaria infantil y

24 Cf. asimismo Boada (1985) y Díaz-Plaja (1988: 21), entre otros. Sirvan como ejemplo las palabras de Cervera (1990: 67): «Por una serie de circunstancias que resultaría prolijo enumerar no parece exagerado afirmar que nos encontramos ante una nueva literatura infantil española o, por lo menos, ante una nueva etapa de la misma. Tal vez su gestación haya sido larga, si tenemos en cuenta algunos de los factores que han propiciado este nacimiento. [...] Cuando una manifestación artística reclama la ayuda de la teoría, la crítica y la investigación, para su perfeccionamiento, es porque ha superado ya la etapa de su infancia, caracterizada por la lucha por la supervivencia. Entra en otra, cuya característica más destacada es la madurez. Sentir la necesidad de tales ayudas supone ya, por lo menos, un deseo consciente de maduración. Y esto parece ser lo que le está sucediendo ahora mismo a la literatura infantil española».

25 Resultan interesantes a este respecto las publicaciones de los informes sobre el Ministerio de Educación y los estudios de fundaciones vinculadas al libro infantil y juvenil como la Sánchez Ruipérez. Así, recomendamos la lectura, entre otros, de los siguientes informes: Análisis, 2002; Hábitos de lectura y compra de libros, 2002; Informe SGAE, 2000; J. A. Millán, 2002; Las bibliotecas públicas en España, 2001; Las colecciones de las bibliotecas públicas, 2003; Panorama de la edición de libros, 2003; Panorámica de la Edición, 2002; Resumen informativo, 2001. 
juvenil supone el $11 \%$ del total. Imaginamos que todo depende del concepto que se aplique de literatura infantil, sobre todo, de su extensión. En todo caso, el porcentaje es considerable. Asimismo el ambiente en el que el niño se desenvuelve facilita el hecho de que los niños se conviertan en lectores. ${ }^{26}$

Las cifras de lectores frecuentes se mantienen fijas en casi todas las franjas. Sin embargo, los lectores ocasionales deberían ser los principales destinatarios de las campañas de lectura. Por último, se refleja en los informes el hecho de que la lectura no se vincula al ocio sino al aprendizaje, lo cual supone un grave escollo para el fomento de la lectura y para el análisis de las pautas que mueven la LIJ. Sin duda, este último factor es uno de los aspectos que intenta superar lo que ahora ha dado en denominarse «educación literaria» (cf. Mendoza, 2004).

La necesidad de reflexionar sobre el presente y el futuro de la literatura infantil viene justificada por la sensación de caos en la que insisten todos los sectores relacionados con el mundo del libro infantil, desde los editores hasta los propios creadores. ${ }^{27}$ Uno de los pilares sobre los que se sustenta el edificio de la literatura infantil es, sin duda, el de la crítica tanto científica como periodística, teniendo en cuenta, como señalaba Vázquez (1993: 25), que "la mejor crítica periodística es la que permanece atenta a las aportaciones de la crítica científica y sabe adaptarlas a las características de su medio».

Si los libros infantiles suponen en la actualidad, como hemos señalado anteriormente, un porcentaje muy elevado de la producción total de obras literarias en España y la oferta crece de tal modo que resulta imposible abarcar todo lo que se publica, es indispensable la existencia de una crítica fundamentada en todos los órdenes para ejercer una labor de selección. No hay que soslayar el hecho de que los libros infantiles son libros escritos por adultos, recomendados por adultos y dirigidos, en última instancia, a los niños. Esta realidad implica por parte del crítico una mayor responsabilidad a la hora de ejercer su tarea. En este mismo sentido se expresa Fernández Paz (1998: 16):

26 En estos mismos datos insistían Fernández, 1999: 8; Fernández, 2000b: 8; Chapa, 2000: 103

27 Cf. X. Blanch, 2000; M. Bragado, 1999. 


\begin{abstract}
Creo que precisamos de una crítica que trascienda los lugares comunes, las aproximaciones superficiales al texto y que penetre más adentro [...]. Una crítica que señale cuándo los caminos recorridos están ya muy andados y cuándo significan algo nuevo [...]. Una crítica que, en un panorama como el actual, nos ayude también a los que escribimos a distinguir entre los libros llenos de vida, esos que nos emocionan al leerlos, que nos ayudan a ver la realidad de un modo diferente, y los libros que, aunque bien escritos, pulcros y correctos, sentimos que están vacíos.
\end{abstract}

Osoro (2000: 137) es todavía más contundente en su exposición:

A lo largo de estos días ha ido asomando tímidamente otro personaje importante en esto de la Literatura Infantil y Juvenil y creo que es precisamente la tibieza con que lo invocamos una de las causas por las que este tipo de literatura no avanza ni arraiga ni es valorada social y académicamente. Este personaje necesario pero molesto es la Crítica.

Tradicionalmente la crítica sobre la literatura infantil se ha preocupado por establecer los parámetros de calidad con el fin de discernir entre los buenos y los malos libros. ${ }^{28}$ Hoy, como señala Colomer (2002b: 12), sin ignorar esta finalidad, muchos estudiosos se han centrado en determinar la forma en que los libros infantiles y juveniles desarrollan la competencia literaria de los receptores. Sea como fuere, lo que constituye una realidad es que la crítica no acaba de encontrar su lugar ni de ejercer su función. No podemos olvidar que la literatura infantil es, ante todo, literatura y precisamente es la crítica literaria la que parece haberse desarrollado en menor medida en este sector. Habría que preguntar por qué, mientras los estudios psico-pedagógicos ${ }^{29}$ han ocupado su lugar en el análisis de la literatura infantil, la crítica literaria no ha respondido a las expectativas deseadas.

Una de las causas por las que ha ocurrido lo anteriormente expuesto es la falta de formación en la tarea de la crítica desde la filología. ${ }^{30}$ Esta

28 Así uno de los últimos estudios, más bien manuales, publicados en el ámbito que nos ocupa, el de Ruiz Campos (2000: 42-47), incluye en su primer capítulo un procedimiento de evaluación de libros infantiles, siguiendo la normativa de la UNESCO a partir de criterios no estrictamente literarios.

29 El lector interesado puede consultar, entre otros, estudios como los de Bettelheim (1976), Soriano (1995), Jan (1977), Abbadie-Clerc (1977), Applebee (1978), Tucker (1981), Held (1981), Escarpit (1986), Patte (1987), Jean (1988), Wells (1988), Nobile (1992), Gárate (1994). Cf. asimismo las compilaciones de Cerrillo y García Padrino, 1999; Llorens García, 2000a y 2000 b.

30 Cf. López Royo y Cencerrado Malmierca, 1997: 64. 
ausencia ha motivado que sean personas formadas en psicología o pedagogía, ámbitos de mayor vinculación a la infancia, las que hayan asumido la labor de analizar, evaluar y criticar los libros infantiles. De este modo, en la valoración del discurso literario infantil han primado los parámetros psico-pedagógicos sobre los literarios, como bien señalan Ballaz (1996) y Garralón (1999). Esta última en un reciente artículo (2004: 3-4) habla de las carencias que observa la crítica en la LIJ y coincide con lo aquí expuesto en que es necesario, en primer lugar, saber cuál es el contenido de la crítica y cuál el público al que va dirigida. Por otra parte, el predominio de los valores temáticos y educativos sobre los puramente literarios es otro de los rasgos que los estudiosos señalan de forma unánime.

Colomer (2002b: 8-9) establece los criterios de valoración que debería tener en cuenta toda crítica que intentara orientar las creaciones infantiles y juveniles. De este modo, señala como pautas válidas la calidad literaria, los valores morales, la opinión del lector y el itinerario de aprendizaje en lo que respecta a la educación literaria. Asimismo, se recogen ideas como las de respetar la opinión de los receptores últimos además de la de los mediadores, tal como mencionaba Moreno (2003: 156) cuando exponía, con cierta ironía, que la crítica debía ser realizada justamente por los niños. En este sentido, resulta de especial importancia el «Manifiesto contra la invisibilidad de la literatura infantil y juvenil» ${ }^{31}$ (Fernández Paz, 1998), firmado por profesores, bibliotecarios, escritores e ilustradores que reivindicaban una crítica rigurosa que orientara a los mediadores y a los niños como segundos receptores. Steiner (2003) defiende que la crítica debe enseñar qué releer y cómo hacerlo, debe establecer vínculos y preguntarse por la contribución a la inteligencia moral. Sea como fuere, todavía estamos solicitando una crítica que discrimine entre la buena y la mala calidad literaria. Claro está, a los criterios literarios habrá que sumar los pedagógicos o de formación en aras de un lector infantil que desarrolla su competencia literaria y su itinerario lector. Estrechamente vinculada a la crítica se encuentra la confección de un canon a la manera de Bloom (1997). A este intento obedecen iniciativas como las de Entrequinientos (2000) o la publicación de Cien libros para un siglo (2004) del equipo

31 Disponible también en http://imaginaria.com.ar/04/1/manifiesto.htm. 
Peonza. Obras como las mencionadas y la necesidad de publicar guías de lectura intentan paliar la ausencia de un canon al modo del establecido en la literatura para adultos.

Con el fin de analizar las características del discurso literario infantil, características que lo definan como tal, es necesario aplicar los paradigmas referidos por la teoría literaria. En tanto el interés de las diferentes corrientes de la teoría de la literatura se ha centrado en el texto ha sido muy difícil para la literatura infantil establecer un marco de referencia. Así lo confirma, por ejemplo, en lo que afecta a la literatura infantil española el estudio de J. Cervera titulado Teoría de la literatura infantil (1991). Sin ánimo de restarle el mérito que le corresponde por ser pionero en un campo todavía en ciernes, la obra mencionada carece de un modelo metodológico claro que se refleja en el resultado. Sin embargo, tras la crisis de la poética estructuralista y de los consiguientes modelos formales cuyo principal objetivo consistió en la búsqueda de la literariedad, ${ }^{32}$ los estudios se han desplazado hacia la consideración del hecho literario como una forma de comunicación. Esto implica que además del texto hay que tener en cuenta todos los elementos que intervienen en el acto de la comunicación, incluyendo de este modo al receptor y el contexto de producción y uso de la literatura. Así, la estética de la recepción y la pragmática literaria han caminado hacia una teoría del uso literario del lenguaje (Selden, 1987: 127; Pozuelo Yvancos, 1988: 64-65; Acosta Gómez, 1989: 11), obligando a redefinir el objeto de la teoría poética como una práctica comunicativa, social e históricamente diferenciada, en la que el receptor ejerce su identidad de sujeto funcional en la interpretación de los signos y en la producción de significados.

En este sentido, las líneas de la teoría literaria han confluido con lo que diferentes estudiosos estaban reclamando para la literatura infantil: un marco metodológico y hermenéutico que incida en la especificidad del discurso literario infantil con la finalidad de definir, por una parte, que se

32 Cf. Garrido Gallardo, 1987; Pozuelo Yvancos, 1988: 62-127; García Berrio, 1989: 42-48.

No es éste el lugar para realizar un repaso del desarrollo de la teoría literaria. Por esta razón el lector interesado puede consultar las obras de Garrido Gallardo (1988), Spang (1993) o Aguiar e Silva (1997), además de los estudios mencionados de Pozuelo Yvancos (1988) y de García Berrio (1989). 
trata de un discurso literario y, por otra, que nos encontramos con un receptor infantil. A este respecto, ya Dahrendorf (1980: 13-16) y Bortolussi (1985: 132) señalaban la importancia de la recepción y su influencia en el análisis del discurso: «La lectura o recepción que implica el discurso modificado debe adecuarse a las exigencias impuestas por la naturaleza esencial del receptor».

Sánchez Corral (1992 y 1995), desde otra perspectiva, ha coincidido con lo anteriormente expuesto cuando, en repetidas ocasiones, ha sugerido el camino por el que debe discurrir la investigación sobre literatura infantil, que no es otro que el de la utilización de los diferentes paradigmas metodológicos de la pragmática. Solamente desde las perspectivas que abren los paradigmas metodológicos mencionados se podrá caracterizar la comunicación literaria infantil como una relación peculiar que se establece entre emisor y receptor.

Las líneas iniciadas por Lotman y la Escuela de Tartu (1978), que cristalizaron en lo que se denominó semiótica de la cultura, definieron el texto literario como un texto de codificación plural en el que no sólo intervienen las normas literarias de una tradición concreta sino también los códigos pertenecientes al sistema cultural de la sociedad en la que se inserta, teniendo en cuenta, como subraya Segre (1985), que la literatura no es un reflejo mimético de las condiciones sociohistóricas sino que ejerce una función de modelizador de la realidad a la cual configura y otorga sentido. Asimismo, las teorías de Even-Zohar (1978) y del grupo de Tel Aviv, con la noción de polisistema, concepto en el que se contempla la movilidad de los fenómenos culturales y los paradigmas desarrollados por Bajtin y Medvedev (1985) en lo que se denomina pacto narrativo son de utilidad en la aproximación al discurso narrativo infantil. El significado del texto se concibe como una construcción negociada por autor y lector a través de la mediación del texto. Los límites del significado se hallan en las relaciones entre las intenciones del autor, la cognición del lector y las propiedades del texto durante el proceso de interpretación. Cuando el lector se enfrenta a un texto, se suspenden las condiciones de verdad referidas al mundo real, puesto que el receptor acepta en ese momento respetar las condiciones de enunciación-recepción que emanan del discurso literario, que no son otras que las que provienen del mundo de la ficción (cf. Todorov, 1966 y 1975), como señalaba Tolkien (1964) aludiendo al mundo del cuento y a los mundos primarios y secundarios. De este modo, el lector acepta que la 
situación comunicativa propuesta por la obra es distinta de la situación propuesta fuera de ella. No sólo el lector ha de acceder a este pacto narrativo sino que es necesario que el emisor mantenga una relación recíproca con su destinatario. Así, Shavit (1986) señala que el nacimiento de la literatura infantil no puede explicarse sin vincularlo al concepto de infancia que cada época ha cultivado y a la función educativa que generó el texto literario para niños.

Por otra parte, dentro de la contemplación del hecho literario como fenómeno comunicativo, la teoría literaria, como ya se ha señalado anteriormente, ha centrado su atención en el lector, lo cual interesa sobremanera a la investigación sobre literatura infantil, puesto que desde el estudio de la recepción se puede llevar a la creación de un modelo crítico propio del análisis del discurso literario infantil.

La Estética de la Recepción, iniciada por Iser (1987) y por Jauss (1986), parte de una línea teórica central que no es otra que la de considerar la recepción como función de la forma del texto (cf. Gumbrecht, 1971: 20). Iser (1987) establece la figura del lector implícito como un constructo teórico que explica la preestructuración del significado potencial del texto y al mismo tiempo la actualización de ese potencial del texto en el proceso de lectura. El proceso de lectura consiste en una búsqueda de significado para una textualidad que nada es sin la colaboración del lector, quien, por otra parte, puede confirmar o extrañar su horizonte de expectativas, una de las nociones clave de esta teoría.

Si la teoría de la Estética de la Recepción nos parece adecuada para su aplicación a los estudios sobre literatura infantil, todavía puede ser más valiosa en este sentido la matización que de la misma realiza Eco (1987), quien sostiene que una teoría de la lectura es una teoría del texto frente a quienes sostienen que una teoría del texto es una teoría de la lectura.

\footnotetext{
La inversión del orden es significativa porque afecta a una opción real que hoy día era necesaria; o bien elegir la lectura como el lugar donde se disuelve y hace imposible cualquier teoría fuerte de la construcción textual, o bien se hace ver que la lectura o recepción es una confirmación de la textualidad y no su negación (Pozuelo, 1988: 120-121).
}

Define Eco (1987: 79) el texto como «un producto cuya suerte interpretativa debe formar parte de su propio mecanismo generativo». El texto 
implica un lector modelo, un lector cooperativo previsto a través de los mecanismos de generación de sentido que el propio texto posee.

El lector modelo se constituye como un conjunto de condiciones de felicidad (Searle, 1980) establecidas por el propio texto que deben satisfacerse para que el contenido potencial de un texto quede plenamente actualizado. Marcas textuales como la elección de una lengua, de un tipo de enciclopedia, de un determinado patrimonio léxico y estilístico van configurando un producto, en palabras de Eco (1987: 80), cuya suerte interpretativa debe formar parte de su propio mecanismo generativo (Chambers, 1977). En nuestro país paulatinamente va aumentando el número de los estudios que ha desarrollado esta línea metodológica. ${ }^{33}$ No obstante, es de suponer que todo trabajo que en la actualidad intente aproximarse a la literatura infantil debe tener en cuenta los seis factores esenciales que intervienen en la comunicación literaria: autor/lector reales, autor/lector implícitos y narrador/narratario, tal como recomienda Wall (1991), quien insiste en la importancia de los implícitos para entender el desarrollo de la comunicación literaria infantil.

Por iguales caminos y en la búsqueda de los mismos objetivos, la didáctica de la literatura se centra hoy en el estudio de los mecanismos que intervienen en la respuesta del lector ${ }^{34} \mathrm{y}$ en el progresivo dominio que los alumnos van adquiriendo en la compresión de los mecanismos propios de la convención literaria ${ }^{35}$ (Bierwisch, 1965).

Ya en lo que concierne al género narrativo, los principios aportados por la narratología, en especial por Genette (1989a y 1989b), quien con-

33 Es de rigor mencionar, dentro de esta perspectiva, las aportaciones de estudios como los de Hazard (1977), Held (1981), Bortolussi (1985), Rico (1986), Cerrillo y García Padrino (1990a; 1990 b y 1992) y de este último en solitario (1992). Centrándonos en la concepción de la literatura infantil como un fenómeno comunicativo, hay que destacar los trabajos de Sánchez Corral (1995), Mendoza Fillola (1998) y Colomer (1998). El estudio de Colomer (1998) constituye un análisis muy riguroso del panorama que ofrece la crítica sobre literatura infantil y sobre cuáles son los retos a los que va a tener que enfrentarse en función de los nuevos caminos que marcan las producciones en este ámbito. La segunda parte del estudio está dedicada a la caracterización de la narrativa infantil actual desde las diferentes instancias enunciativas. En aportaciones como esta se refleja la legitimación de la literatura infantil como un área de investigación. Por otra parte, los trabajos de Lluch $(1998,1999$ y 2003) han incidido notablemente en la definición del lector modelo.

34 Cf. Corcoran y Evans, 1987; Benton y Fox, 1992.

35 Cf. Colomer, 1995 y 1997; Colomer y Camps, 1996. 
sidera las diversas formas de transtextualidad (1989b: 10) como un aspecto relevante en el discurso literario, pueden contribuir al desarrollo de una adecuada metodología de análisis. El estudio, por ejemplo, del paratexto constituye un lugar privilegiado de la dimensión pragmática de la obra literaria infantil y juvenil, puesto que no podemos soslayar la importancia de la presencia de un receptor adulto como mediador entre el mensaje y su receptor último, que es el niño. Hay que pensar que dentro de lo que Genette (1989b: 12) denomina paratexto se encuentra un elemento de suma importancia en el marco de la literatura infantil como es la ilustración, además de la trascendencia que adquieren los títulos, subtítulos, intertítulos, prefacios, epílogos, advertencias, contraportadas, etc.

El paradigma metodológico desarrollado por Genette sigue siendo uno de los pilares fundamentales en el análisis del discurso narrativo, junto a las diferencias establecidas por la teoría de la enunciación de Benveniste (1996). Quién cuenta, cómo se cuenta, a través de qué códigos se relata, son cuestiones de vital importancia.

Legítimas y necesarias son las aproximaciones pedagógicas, psicológicas, comerciales y editoriales que componen la bibliografía que versa sobre literatura infantil. Sin embargo, insistimos en ello, es de literatura de lo que se trata.

\section{5. ¿Y la educación literaria?}

Cuando las estadísticas sobre los hábitos lectores de la población no reflejan datos demasiado favorables (cf. Colomer, 2002a: 263-285) la primera pregunta que suele formularse es qué papel desempeña la escuela en la generación de tales hábitos.

En primer lugar, creemos que probablemente a la escuela sólo le corresponda la tarea de desarrollar la competencia lectora y favorecer, en lo posible, el hábito de lectura, de tal modo que su tarea no es tanto formar individuos que necesiten la literatura para vivir sino procurar que los alumnos se acerquen sin miedo a la interpretación de un texto literario. En este sentido, creemos que Moreno (2000) no carece de razón cuando distingue entre individuos que puedan comprender e interpretar un texto literario de aquellos que pueden y necesitan hacerlo. 
La escuela no crea lectores que necesiten la lectura para vivir, sino que debe poner al individuo en disposición de hacerlo. Decía Landero: «Algo se puede hacer: si no enseñar literatura, sí poner en disposición de dejarse seducir por ella» (cit. por Osoro, 2002: 36).

Hoy ya no se utiliza la expresión «enseñar literatura» sino que se habla de educación literaria con la intención de alejarse de la metodología puramente historicista, de las listas de autores y obras, para acercarse al trabajo de la competencia literaria, en una enseñanza basada en el discente. Asimismo, varios conceptos se manifiestan como fundamentales en lo que concierne a la educación literaria y a su reflejo en las aulas y, entre todos ellos, destacaremos los de competencia literaria, comprensión, interpretación e intertexto lector.

Bierwisch (1965) define la competencia como «la capacidad humana que posibilita la reproducción y recepción de estructuras poéticas y que debe ser aprendida socialmente». Se trata, pues, de un progresivo dominio de las convenciones literarias, ya que es necesario aproximarse a la educación de la habilidad lectora para que el lector sepa establecer su interacción con el texto, para que coopere en la recreación de la obra y en la construcción de la interpretación (Mendoza, 2001: 218). En este sentido, hay que distinguir entre comprensión e interpretación. Comprender es sólo asumir lo que el texto indica literalmente. Interpretar implica interiorizar lo comprendido y reformularlo personalmente. Por último, muy ligado a estos conceptos se encuentra el de intertexto lector. Mendoza (2001: 102) lo define como «dispositivo activo de los saberes, estrategias y recursos lingüísticos y pragmático-culturales que se actualizan en cada recepción literaria, con el fin de construir nuevos conocimientos significativos que pasan a integrarse en la competencia literaria». El concepto de intertexto no es nuevo ya que tanto Kristeva (1969), Van Dijk (1983), Todorov (1975), Riffaterre (1971) o Genette (1982) y Eco (1987), entre otros, lo habían tratado señalando que la lectura de un texto siempre se vincula a la experiencia que el lector ha adquirido a través de otros textos con los que inevitablemente se relaciona y forma un entramado.

La educación literaria supone un regreso a los textos dentro de un enfoque comunicativo que contempla la presencia de los mediadores como uno de los puntos esenciales. Desde la consideración de la impor- 
tancia del receptor como estrategia generadora del discurso en su relación con el texto y con el propio emisor, el texto se abre a la contemplación de los agentes sociales que intervienen como intermediarios. Dentro de estos últimos, es necesario valorar con el rigor suficiente tanto a los maestros en el entorno escolar como a las familias, bibliotecarios, libreros, editoriales, etc. El texto no es el único elemento digno de estudio en este circuito sino que el papel de los mediadores se descubre como fundamental en la formación de un lector literario competente. Claro está, la formación de los mediadores no se improvisa, de la misma forma que, en este ámbito, los resultados a corto plazo no existen. El hecho de que el Ministerio de Educación, Cultura y Deporte lance campañas de fomento de la lectura, con la inversión que ello supone en diseño y material, ${ }^{36}$ no asegura los resultados si no existe una continuidad en los impulsos. Y si mencionamos la continuidad, es necesario aludir a experiencias de formación de intermediarios ${ }^{37}$ que han cosechado algunos éxitos, casi todas ellas ligadas a la formación de grupos de lectura. En esta línea, la escuela debe desempeñar una labor fundamental en la construcción de un itinerario en la interpretación (Mendoza, 2004). Partimos de la base de que a hablar se aprende hablando, a leer, leyendo y a interpretar, interpretando. Si bien en la adquisición de esta habilidad literaria, es fundamental no sólo la elección de una metodología adecuada sino también la selección de un corpus de literatura infantil y juvenil que asegure el éxito de la empresa o, al menos, que no la entorpezca demasiado.

Una vertiente fundamental en la educación literaria es la metodología en que debe sustentarse la formación del lector competente. Varios han sido los estudios que en los últimos años se han dedicado a intentar definir cómo debe acercarse el texto al receptor. Así, Cerrillo y García Padri-

36 Nos referimos, por ejemplo, a una espectacular campaña ministerial que en el año 2002 se llevó a cabo en aras del fomento de la lectura. El material de aquella campaña fue muy cuidado en su elaboración, las ilustraciones resultaron ser magníficas y la línea metodológica de actuación resueltamente inadecuada puesto que abolía cualquier principio de gratuidad, de selección, etc.

37 Sirva como ejemplo el proyecto Leer juntos llevado a cabo por el C. P. Francisco Galiay de Ballobar. Esta experiencia ha supuesto un ejemplo de lo que se puede llegar a alcanzar cuando la formación del mediador adquiere un carácter continuado y sólidamente fundamentado, tanto en lo que respecta a los soportes teóricos como en lo que concierne a la selección y guía de las obras escogidas. 
no (1996), Cerrillo, Larrañaga y Yubero (2002), Durán (2002), Equipo Peonza (2001), Machado (2001), Osoro (2002), entre otros, han constituido puntos de referencia en este aspecto. Asimismo, podríamos establecer un decálogo — a la manera de Pennac (1993) — de las premisas de las que parte la educación literaria en estos momentos:

1. Los libros no se trabajan, se disfrutan y se comparten. No pueden y no deben constituir un pretexto para finalidades espurias.

2. Es necesario subrayar la gratuidad del acto de lectura y el placer que el mismo produce sólo por el motivo de no solicitar nada a cambio.

3. La elaboración de las tradicionales "fichas de lectura» debe ser revisada puesto que elimina la gratuidad del hecho de la lectura.

4. La lectura en voz alta por parte del adulto - maestro, bibliotecario, animador, padre o madre...- debe volver a las aulas aunque sólo sea por el placer de contar. Como muy bien comentaba Martín Garzo (2003: 18):

Escribimos para que [el otro] se detenga y nos oiga contar. No importa lo que contemos, sino que esté a nuestro lado y nos escuche. Porque contar una historia es, por encima de cualquier otra cosa, contemplar el rostro del que la escucha.

5. La «lectura de cercanía» (Osoro, 2002) o la idea de Pennac (1993) de que no hay que abandonar al niño en sus lecturas por mucho que este haya aprendido a leer están estrechamente ligadas a lo que expone Martín Garzo (2003) como la posibilidad de las palabras de ligarnos con lo ausente.

6. La lectura debe ser compartida. Nunca se puede impartir, ya que sería algo paradójico. El placer no se imparte sino que se comparte (cf. Osoro, 2000: 32).

7. Por lo tanto, una de las dinámicas más exitosas, sobre todo en los niveles superiores, es el «hablar de libros», el recomendarlos a los demás, el explicar por qué merece la pena leer un libro, qué hemos sentido, qué hemos experimentado.

8. Sólo se recomienda con el suficiente entusiasmo aquello que realmente nos ha cautivado. 
9. Landero (cit. por Osoro, 2002: 33) afirma que «sólo se puede contagiar aquello que verdaderamente se ama, aquello que forma parte de nuestras pasiones más íntimas y preciadas». Leer por «contagio» es, por tanto, una de las posibilidades.

10. Es necesario ofrecer un abanico amplio de posibilidades y combinar la recepción con la creación en un contexto educativo de construcción compartida. La creación no tenderá a la formación de artistas sino a complementar el ejercicio de reflexión sobre el proceso de formación del texto.

Las actividades de animación a la lectura merecen un comentario especial puesto que han sido revisadas por las nuevas propuestas de educación literaria. Entendemos por animación a la lectura «una serie de estrategias y actividades dirigidas a despertar en las personas el deseo de leer» (Docampo, 2002: 50). Uno de los principales reproches que se ha realizado a este tipo de actividad de refuerzo es la pérdida de contenidos, de tal modo que, en ocasiones, el método se ha convertido en el propio fin y el texto resulta sólo un pretexto para desarrollar un espectáculo completo en sí mismo. Detrás de las actividades de este tipo que se extendieron durante los años ochenta y noventa en bibliotecas y centros escolares (Colomer, 2002a: 280-281) se esconde una desconfianza clara en el poder del texto y un temor ante una actividad que, al fin y a la postre, requiere un esfuerzo y debe desarrollarse a través de una labor individual.

Una vez reconocida la importancia del mediador que funciona como mecanismo generador de un discurso que se define, entre otros rasgos, por la presencia de un receptor infantil y un receptor adulto coincidente a su vez con el mediador, entendemos como otro de los pilares básicos de la educación literaria la selección del corpus de literatura infantil y juvenil. El mediador adulto debe ser asesorado y guiado en un mercado que soporta un número ingente de publicaciones al año. Bien es verdad que la crítica especializada no acaba de ejercer su papel, puesto que se echan de menos criterios en la labor de selección del corpus y el panorama se muestra harto complicado (Ballaz, 1996; Garralón, 1999; Colomer, 2002b). Por otra parte, se publican guías, listas, tesoros ${ }^{38}$ que no acaban de llegar

38 Cf. Castañeda y otros (1993), Barrena y otros (2000), Entrequinientos (2000), Fernández (2000), González (1997, 1998 y 1999), Yubero et al. (2002), entre otros. 
fácilmente a los destinatarios oportunos. ${ }^{39}$ Además, las editoriales, guiadas por los intereses de mercado, optan por lo políticamente correcto, de tal modo que sobra didactismo y escasean los criterios puramente literarios.

Colomer (2002b), en un interesante artículo, intenta establecer los parámetros por los que se puede valorar un buen libro intentando huir de aspectos únicamente ideológicos, puesto que la historia ha demostrado que uno de los lastres que ha hipotecado el discurso literario infantil es la necesidad de formar al lector. En el fondo, lo que subyace no es otra cuestión que la desconfianza en la competencia literaria de un lector al que hay que explicitar, en ocasiones, demasiado.

Aspectos como las relaciones entre textos y paratextos, la observación del pacto de la narración, el tono de la historia, la cohesión de la misma, la previsibilidad o imprevisibilidad de los finales, las características de la voz, la presencia del narratario o la estrategia de la doble recepción son factores dignos de análisis en la valoración de la calidad de lo que se ofrece al lector infantil. ${ }^{40}$

En definitiva, es casi imposible ofrecer una receta para crear lectores. Quizá con un poco de entusiasmo, un poco de cercanía y, sobre todo, con una extrema confianza en el poder sugeridor, en la magia de la palabra, podríamos aproximarnos a la receta exacta. Sin embargo, como en la buena cocina, al final, el secreto se encuentra en el punto justo. Y sólo seremos capaces de crear lectores si creemos en la verdad de lo que postulamos y transmitimos con entusiasmo puesto, que sólo «contagiaremos» aquello que de verdad sentimos.

\subsection{La literatura infantil en el marco de la enseñanza}

La falta de estudios desde la perspectiva literaria, la inadecuada formación de los mediadores, la ausencia de rigor en algunos sectores de la crítica

39 Últimamente es de reseñar la aparición de direcciones de internet en las que se reflejan las novedades editoriales (cf. Reoyo, 2001). Asimismo, el portal denominado SOL no acaba de resultar una entrada de fácil navegación y prioriza además las líneas temáticas sobre otras de carácter marcadamente literario.

40 G. Lluch (2003) expone un modelo de análisis ecléctico en la aproximación al discurso narrativo infantil. 
son aspectos que contribuyen a confundir un panorama excesivamente complicado. Uno de los factores que, a nuestro entender, se dibuja como definitivo es la insuficiente presencia de la literatura infantil en la universidad, lo cual influye en la falta de formación filológica de los profesionales vinculados posteriormente al mundo del libro infantil. Hemos de reconocer, no obstante, que los planes de estudio de 1971 (cf. Cerrillo, 1990) concernientes a la diplomatura de Magisterio, y sobre todo el Plan 91, han supuesto un avance no demasiado satisfactorio en la consideración de la Literatura Infantil como materia universitaria. Tildamos el avance de poco satisfactorio porque, en este momento, y a la espera de que se produzca la incorporación de las titulaciones al marco europeo, la literatura infantil solamente aparece como materia troncal en el título de Maestro Especialista en Educación Infantil, con 4 créditos (3 teóricos y 1 práctico). Resulta, pues, a todas luces incoherente la exclusión de la materia en la especialidad de Primaria, ${ }^{41}$ tal como declaraba L. Sánchez Corral (1995: 120). Así, cada universidad ha resuelto, con mayor o menor fortuna, este lamentable panorama a través de la introducción de la literatura infantil en la obligatoriedad y en la optatividad de todos los títulos de Maestro (cf. Moreno y Vera, 2000: 19-23).

La presencia de la literatura infantil en los estudios de segundo ciclo se reduce, según los datos presentados por Moreno y Vera (2000: 18), a una asignatura en la licenciatura de Psicopedagogía de la Universidad de Cádiz. Si tenemos en cuenta que la mayor parte de los profesores que imparte las asignaturas relacionadas con la literatura infantil procede de la licenciatura de Filología Hispánica, convendremos en señalar que el dato no carece de trascendencia. Además el panorama en Secundaria resulta desalentador. La literatura juvenil no acaba de ocupar el lugar que debiera en las llamadas «lecturas regladas» y los profesores que se hacen cargo de la enseñanza de la misma se sienten más seguros transmitiendo la llamada literatura canónica que, en más de un caso, no observa las condiciones de recepción del alumno de Secundaria. En muchas ocasiones, es el desconocimiento de la literatura juvenil el que provoca este tipo de situaciones. Bien es verdad que el panorama de esta literatura no resulta demasiado atractivo por la falta de innovación en los modelos, por la concesión extrema a las demandas del destinatario, por la recurrencia de los temas, etc. (Dueñas y Tabernero, 2004).

41 Cf. Cervera, 1992: 12; García Padrino, 1993: 207. 
En lo que concierne a los estudios de tercer ciclo, el marco resulta más alentador puesto que son varias las universidades que ofertan cursos de Literatura Infantil en los programas de doctorado en Educación o en Didáctica de la Lengua (cf. Moreno y Sánchez Vera, 2000: 18).

La situación de la literatura infantil en el ámbito universitario no es, pues, demasiado halagüeña y viene a justificar, en gran medida, la dejación de funciones que la crítica filológica ha realizado en lo que respecta a esta materia. Así, Cerrillo y Utanda (2000: 25) afirman:

La universidad, entre sus funciones, tiene la de dar respuesta a las demandas educativas y culturales de la sociedad [...] La realidad actual de la literatura infantil, con más de cuatro mil títulos editados cada año, con una población lectora importante y con bastantes buenas colecciones, no tiene la valoración social e institucional que debiera tener, ni tampoco la correspondencia que debiera ser necesaria en el proceso formativo de los futuros docentes, ni de Educación Primaria, ni de Educación Secundaria.

Habría que añadir a estas afirmaciones que en el esquema de comunicación que caracteriza a la literatura infantil, los profesores ocupan un lugar fundamental en el proceso de mediación y recepción. Si estos no se encuentran lo suficientemente formados ni asesorados por una crítica sólida, difícilmente aseguraremos que el alumno de cada uno de los ciclos conozca los libros infantiles y juveniles destacados por su valor artístico y estético que, a la postre, son los que cultivan la competencia literaria del futuro lector.

García Padrino (1993: 201) escribía que la futura formación del profesorado para los primeros niveles educativos se ha desliteraturizado por decreto y relacionaba esta desliteraturización con «la culminación de una actitud social que desdeña lo humanístico y, por tanto, lo literario, frente al interés por las materias científicas y, en el caso de la formación del profesorado, de las materias psicopedagógicas». Coincidía en este aspecto con lo que ya habían señalado Amorós (1984) y Montero Padilla (1992).

Es, pues, inexcusable que el futuro profesor que se está formando en Didáctica de la Lengua y la Literatura tenga un conocimiento de la literatura infantil en todas sus manifestaciones, problemas y posibilidades, como afirman López Valero (1992) y Mendoza Fillola (1994), más aún cuando los diseños curriculares tanto de Educación Infantil y Primaria como de Secundaria incorporan explícitamente la educación literaria a través de los textos apropiados. 
Con todo, en estos últimos años se ha conseguido una consolidación de la materia y una presencia en los planes de estudio universitarios de primer y tercer ciclo. Por otra parte, la realización de tesis doctorales relacionadas con la literatura infantil y juvenil ha contribuido a desarrollar el estatus académico y científico que le corresponde. Paulatinamente, pues, vamos dejando atrás el autodidactismo en el que se vio inmersa buena parte del profesorado que se ha dedicado a la LIJ en las aulas.

\subsection{Para terminar}

El panorama en el que está inmerso actualmente el discurso narrativo infantil es complicado por la cantidad de factores que interviene en su gestación y por la necesidad evidente de adaptarse a un doble receptor - el del siglo XXI- que marca de principio a fin cada una de las instancias enunciativas propias del hecho literario. A ello, a estas instancias y a intentar exponer cómo la peculiaridad de la recepción funciona como mecanismo generador del discurso, dedicaremos los siguientes capítulos. 


\section{CAPÍTULO 2 OTRAS FORMAS DE CONTAR: LOS PARATEXTOS EN EL DISCURSO NARRATIVO INFANTIL}

Habría que remontarse hasta Aristóteles, Cicerón y Quintiliano y recorrer un camino que nos llevaría sin ninguna duda a través de nombres como los de Propp (1928), Hamburger (1959), Barthes (1966), Brémond (1966), Todorov (1966), Greimas (1970), Genette (1966, 1987, 1989a, 1989 b y 1998), Iser (1987) o Bajtin $(1989)^{1}$ para intentar desentrañar lo que diferencia un texto narrativo de otro que no lo es. Siete rasgos define Spang (1993: 104-105) como básicos para diferenciar el modo narrativo del lírico y del dramático:

1. La presentación a través de una historia narrada de un mundo posible. Inferimos del contexto que Spang utiliza el término historia en el sentido en que lo usa Bal (1995: 57) de determinada presentación de una fábula, lejos del empleo que del mismo realizan los formalistas rusos (Shklovski, 1925; Tomashevski, 1982, entre otros) como material que todavía no ha recibido forma dentro del texto narrativo.

2. Presencia del narrador, quien funciona como intermediario entre la historia y el receptor. Aún añadiríamos, si se nos permite, que el narrador realiza la función de intermediario entre el autor y el receptor.

1 Cf. a este respecto García Berrio, 1989; Pozuelo Yvancos, 1988; Spang, 1993; Garrido Domínguez, 1993; Aguiar e Silva, 1997. 
3. Literariedad y ficción se encuentran indisolublemente vinculadas.

4. Se cuenta la subjetividad de terceros, lo que otros piensan y cuentan.

5. Otro rasgo que señala el autor como propio de la narrativa es la utilización de la palabra como único medio de expresión. Más adelante se aclara: «La narrativa es esencialmente verbal y si hay algunos textos con ilustraciones, mapas, dibujo, fotos, etc. estos forman la excepción y no la regla» (1993: 105).

6. La objetividad, entendiéndola como «la necesidad del autor narrativo de disponer de un mundo material para plasmar su historia", constituye asimismo una condición indispensable para determinar la esencia de lo narrativo.

7. Por último, Spang (1993: 105) se refiere al carácter diferido de la comunicación en el discurso narrativo (sermo absentis ad absentem).

Si exceptuamos el punto quinto, los demás rasgos propios del modo narrativo para adultos son válidos para el discurso narrativo infantil. Así pues, los elementos que diferencian la narrativa infantil de la dirigida a los adultos no pueden establecerse en el marco de la definición de los géneros, tal como sugirieron implícitamente algunos investigadores como López Tamés (1985: 15) o Cervera (1991a: 12).

La clave del discurso narrativo infantil, pensamos, se encuentra en la interpretación del mismo a la luz del esquema comunicativo. Desde el punto de vista pragmático, hay que considerar no sólo la información que nos proporciona el propio texto sino también los agentes que realizan la función de intermediarios entre el emisor y el receptor. En la literatura para adultos, pues, el esquema de la transmisión queda como sigue: $^{2}$

1. AUTORES

2. EDITORES

3. LECTORES

4. CRÍTICOS

2 Schmidt (1987) recoge un esquema parecido, adaptado después por Lluch (1998). 
Los autores crean y producen el texto, lo presentan a los editores, que son los que se encargan de transmitirlo a los receptores. En última instancia, la crítica puede sancionar un texto como literario o no hacerlo.

El editor realiza las veces de mediador, por tanto, atendiendo a factores de calidad literaria y de mercado, de oferta y de demanda. Es evidente que este mediador influye en la producción del hecho literario aunque se pueda confundir con el lector como estrategia discursiva.

En el ámbito de la literatura infantil el esquema de transmisión sufre variaciones considerables, sobre todo en lo que respecta a la recepción y a la mediación.

El esquema quedaría como sigue:

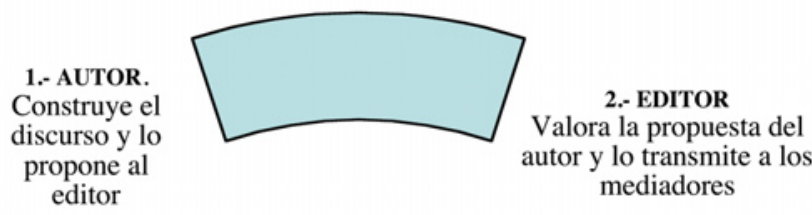

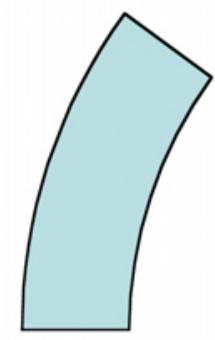

5.- SEGUNDO RECEPTOR:

lector infantil

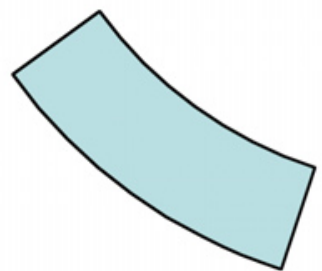

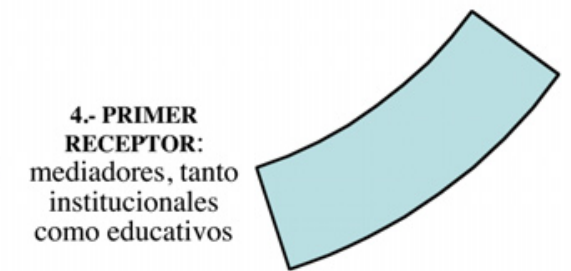

3.- MEDIADORES

Institucionales Educativos

Padres y maestros. 
Se desprende de este esquema que la variación fundamental respecto de la narrativa para adultos se encuentra en la mediación que, a su vez, funciona como primera recepción.

El primer mediador, sin duda, es el editor. Si bien es verdad que este último valora las propuestas y las demandas de los demás mediadores, los institucionales y los educativos, puesto que uno de los principales motores de las editoriales, en lo que respecta a la literatura infantil y juvenil, es la incorporación al mercado escolar.

La función del editor hoy es básica en el desarrollo de la literatura infantil. El editor realiza las veces de agente de transformación en el esquema de la comunicación literaria que hemos presentado. Así expone Bragado (1999: 26) cuáles son las funciones del editor:

Pero el editor hace más que seleccionar los contenidos, ya que también los valida y los introduce en un contexto. Esta legitimidad de la validación del editor está amparada por su trayectoria anterior, por el sello editorial y por la autoridad moral que representa su marca. El nuestro es un oficio basado en la seducción, en convencer a los lectores, a lo largo de años, que necesita libros de nuestra editorial, en conseguir que la fidelidad no sólo no los aburra, sino que se convierta en adicción.

Blanch (2000: 94) ofrece una perspectiva más completa de las funciones del editor:

Empresarialmente, un editor es el fabricante de un catálogo de productos culturales; comercialmente, un editor es el intermediario entre proveedores de base - los autores - y los clientes finales —el público lector-; profesionalmente, un editor es el coordinador del proceso de transformación industrial — sector de las artes gráficas - de una materia prima obtenida artesanalmente - texto e imágenes originales—; socialmente, un editor es el sello de una empresa cultural; y, culturalmente, un editor es el creador de vehículos transmisores de pensamientos y emociones.

El editor es el responsable del tratamiento tipográfico del texto, de la elección del ilustrador, de las calidades de los materiales que se utilizan y, a su vez, es el encargado de financiar las producciones y asegurar la difusión, promoción y distribución de las obras que edita. ${ }^{3}$ Es en esta última función en la que el editor, además de guiarse por criterios culturales, se

3 Cf. Ph. Schuwer, 1994; B. Legendre, 1996; G. Mata, 1999. 
deja llevar por criterios económicos; una editorial debe ser rentable para asegurar su presencia en el mercado. Los clientes de las editoriales no son los lectores sino las librerías, las grandes superficies, las distribuidoras, las bibliotecas, los centros educativos e, incluso, las instituciones públicas, ayuntamientos, diputaciones y gobiernos autonómicos. A todos ellos hay que persuadir de que el producto que se les ofrece va a interesar al cliente final, que no es otro que el público lector. Ciertamente la complejidad del mundo editorial se acentúa cuando nos acercamos al panorama de la edición de libros infantiles.

En un artículo de la revista Cuadernos de Literatura Infantil y Juvenil (1993: 42-53) dedicado a los editores galardonados con los Premios a la Edición 1992, del Ministerio de Cultura, los directores de las editoriales Anaya, Aura Comunicación, Destino, Pirene y SM realizaban una valoración del momento de la edición infantil y juvenil española. Todos ellos coincidían en señalar que el mercado estaba saturado de publicaciones en las que vale todo, en aras de la preocupación didáctica, puesto que la escuela marcaba la producción editorial. Jufresa (1993: 48), directora de la editorial Destino, señalaba que los libros no destinados al consumo escolar padecían una gravísima debilidad de mercado que los hace casi inviables. En esta misma línea, Besora (1993: 46), director de Aura Comunicación, afirmaba:

La escuela continúa imponiendo las directrices por las que se rige la literatura infantil y juvenil en la actualidad, cuyo objetivo es conquistar al niñoalumno, como lo denominaba Rodari, en contraposición al niño-que juega, a quien se le conquista con libros nacidos de la imaginación por la imaginación. La balanza está muy desequilibrada. Los libros con un contenido imaginativo, los libros de imágenes, los libros bellos, se pierden entre un alud de colecciones - y las hay excelentes-, que mezclan la ficción con la intención de informar y de una gran cantidad de títulos de dudosa calidad literaria que acostumbran a mostrar estereotipadas representaciones de la adolescencia y sus problemas.

Interesantes también son las afirmaciones de Boada (1993: 50), quien expone un panorama difícil y oscuro para el libro infantil y juvenil que no entra en la escuela e, incluso, para el que entra en tal lugar:

En el común de los editores especializados, echo en falta el trasfondo cultural general de unos pocos años atrás; ahora sólo parece contar el ánimo de lucro - aunque promocionalmente se hable sólo de cultura, claro-, reminis- 


\begin{abstract}
cencias de un pasado aún reciente. Los profoescriptores — perdón otra vez- se han dado de narices contra unas redes comerciales que se lo ofrecen «a buen precio y en bandeja», incluyendo la ficha de trabajo de cada libro, ¡faltaría más! Y los niños - los últimos monos, como casi siempre- son mayoritariamente engañados o cuasiengañados — perdón por tercera vez-, pues los libros, esos libros de que hablo por lo menos, se concibieron para ser leídos, no para ser trabajados - bueno, ya no todos, pues los autores se están contagiando aceleradamente del afán de lucro impulsado por la mayoría de editores y rápidamente han aprendido que si escriben libros trabajables venden más-. Menos mal que todavía, buscando bien, se puede encontrar a alguien que cree que en la escuela, si hay que trabajar un libro, es sólo para enseñar a leer y a leerlo mejor, nada más.
\end{abstract}

El panorama de la edición de libros infantiles sigue siendo desalentador, tal como expone Blanch (2000: 94-99). Por una parte, la producción de libros infantiles es técnicamente más variada y compleja que cualquier otra línea editorial y la promoción pasa necesariamente por la escuela:

\footnotetext{
Lo que sabe a ciencia cierta cualquier comercial de una editorial de libros infantiles es que a quien tiene que "vender" primero sus libros es a los maestros y a las maestras. Si un libro entra en la escuela, se vende en la librería. La escuela es el gran canal de penetración de las ofertas editoriales infantiles. Maestros y maestras son prescriptores de las lecturas de los pequeños (Blanch, 2000: 95).
}

Siendo cierto lo expuesto, la escuela, sin embargo, no dispone de una infraestructura adecuada para promocionar el gusto por la lectura de sus alumnos. Las bibliotecas escolares carecen de presupuesto y no están dotadas de los fondos pertinentes.

Por otra parte, la literatura infantil apenas existe en la prensa de información general, la crítica literaria infantil reduce su presencia a las revistas especializadas que lee un público minoritario. Sólo las grandes editoriales pueden promocionar sus libros tal como exige el mercantilismo imperante.

Desde la perspectiva que nos ocupa, las consecuencias son previsibles. El editor se va a debatir entre intereses comerciales para intentar persuadir al mediador adulto de que el libro que comercializa responde a sus necesidades y parámetros en los que se defiende la calidad aunque resulten menos rentables. Así se explican estas palabras de Ferrer (2004: 4):

En el panorama actual conviven editoriales que de alguna manera responden a los planteamientos que observamos en alguna de las tres etapas de la antigua editorial de Saturnino Calleja; una primera más didáctica, pegada al 
mundo escolar; una segunda más creativa y artística, y una tercera eminentemente comercial [...]. Es difícil conciliar la actividad empresarial con la de agente cultural, ya lo dijimos al principio, y en el fondo no dudo de que todos los editores lo intentan; sólo que lo de «agente cultural», que suena tan raro, se presta a todo tipo de interpretaciones. Hay quien se sabe agente cultural, y realmente lo es, como se es agente secreto o agente de seguros; y hay quien no tiene remota idea de qué demonios significa eso y no se molesta en averiguarlo; juega y se entretiene con los libros, y es lector antes que nada: edita lo que le gusta y hace cada libro distinto (Kókinos), se convierte en escaparate de nuevos ilustradores (Kalandraka), publica libros arriesgados del panorama internacional (Lóguez), rescata los clásicos modernos de nuestra tradición (Olañeta).

Es preciso dejar pasar algo de tiempo para averiguar si estas y otras editoriales, que representan opciones que tratan de escapar a la norma, son capaces de mantenerse en el mercado; para ver cómo evolucionan. [...] Considerada en su conjunto, la producción tiende a ser muy conformista y está contagiada por los vicios que afectan al mercado del libro en general (Ferrer, 2004: 4).

En otro reciente artículo que versaba sobre educación literaria las palabras eran las siguientes:

Y es que, como nos dice A. Camps, la producción editorial no se mueve exclusivamente por las necesidades de la escuela sino que plasma su interpretación de los currículos educativos, y estos no proponen la educación literaria que sería de desear. Por otro lado, resulta fácil suponer que si sus propuestas fueran muy innovadoras seguramente las ventas no serían tan elevadas. Así pues, con un aire renovado, esconden planteamientos más bien tradicionales y simplistas (López Molina, 2004: 10).

Satué (1998) establece que el buen editor es el que combina la sensibilidad artística, intelectual y comercial, a las que Lluch (2003: 38) añade la pedagógica, que define como la vertiente que aporta su opinión sobre lo que es más adecuado para cada nivel lector. Sea como fuere, el componente económico de mercado es insoslayable, aunque se trate de agentes culturales, y a este componente parecen supeditarse los demás.

Las instituciones educativas serían las instancias encargadas de valorar la adecuación de los libros a la recepción infantil. Por poner un ejemplo, el hecho de que la LOGSE haya contemplado las llamadas áreas transversales ha influido en la aparición de una literatura de valores que trata sobre el respeto, la tolerancia, la conservación del medio ambiente, la igualdad de oportunidades, la educación en la diversidad... En definitiva, un didactismo que, en ocasiones, consigue desvirtuar la calidad literaria en aras de la explicitación de mensajes puramente didácticos. 
En estos momentos es verdad que no se puede hablar de demasiadas prescripciones explícitas como ocurrió en algunas décadas durante este siglo (Cendán Pazos, 1986; García Padrino, 1992 y 2001), aunque la ideología dominante sigue por los cauces de lo políticamente correcto de una forma inexcusable. Eso sí, no siempre.

Los llamados «mediadores educativos», los mediadores vinculados al mundo de la enseñanza, es decir, fundamentalmente padres, maestros y bibliotecarios, son los que directamente recomiendan las lecturas a sus hijos o alumnos, en cada caso. Ellos, en última instancia, realizan la labor de selección de las obras que posteriormente aparecerán en las bibliotecas escolares y en las familiares.

La asesoría de la crítica rigurosa es de vital importancia para estos mediadores. Así la elaboración de catálogos, guías de lectura y reseñas bibliográficas puede resultar de gran ayuda en el desarrollo de este tipo de mediación.

Cerrillo (2002: 29-44) define las funciones asignadas a padres, maestros y bibliotecarios e incide en el fomento de hábitos lectores y en la selección de un itinerario de lecturas que contribuya a consolidar la lectura como hábito y afición (cf. Arizaleta, 2003).

No obstante, creemos que se tiende a olvidar la labor que realizan los libreros, algunos libreros, de selección, recomendación y, en definitiva, de promoción de la lectura a través de la literatura infantil y juvenil (Durán, 2002). El librero se dibuja en la actualidad como una de las instancias de mayor influencia en el mediador familiar, como también lo están haciendo, desde otras perspectivas, los denominados cuentacuentos o contadores (Ortiz, 2002).

Y finalmente llegamos al último receptor que no es otro que el infantil, un lector al que toda suerte de mediadores «recomienda», en algunos casos obligatoriamente, que lea ciertos libros y descuide otros que resultan menos «adecuados».

El lector modelo, pues, que funciona como estrategia generadora de significados no sólo es el receptor infantil sino que también es el mediador adulto que recomienda o no la lectura de la obra. Evidentemente, la duplicidad de la recepción está resultando uno de los motores de desarrollo del discurso que nos ocupa. Ya que sólo se recomienda aquello 
que, de una manera o de otra, nos convence. En esta línea, el doble receptor ha constituido, sin duda, el principal factor de innovación en el discurso narrativo infantil y juvenil. Las propuestas más arriesgadas o innovadoras en este ámbito han partido de esta característica. Si bien es verdad que quizá el lastre más perjudicial provenga de aquella.

De este modo, Eco (1987: 80) define la labor de lo que él denomina lector modelo:

Para organizar su estrategia textual, un autor debe referirse a una serie de competencias capaces de dar contenido a las expresiones que utiliza. Debe suponer que el conjunto de competencias a que se refiere es el mismo al que se refiere su lector. Por consiguiente, deberá prever un Lector Modelo capaz de cooperar en la actualización textual de la manera prevista por él y de moverse interpretativamente, igual que él se ha movido generativamente.

Sin duda, el lector modelo que prevé el texto en las obras de literatura infantil es dual. Queremos con ello decir que el propio texto presupone un lector adulto y un lector infantil. El primero realizará las tareas de intermediario, ya que en las edades de los receptores entre las que se mueve este estudio, como señala Viala (1987: 29; cit. por Mendoza, 1998: 29), la lectura no suele ser una elección personal del lector real:

Por el contrario tal «elección» viene determinada y la proponen la institución o los lectores «de segundo grado» que son los representantes autorizados (aquí el profesor, allá los críticos, los jurados y los premios literarios, etc.) para designar ese texto como bello y bueno, bueno porque es bello y bello porque es bueno (Viala, 1987: 29).

Se infiere de lo expuesto que el emisor, si desea que el mensaje llegue al lector infantil, debe antes persuadir al lector "de segundo grado». ${ }^{4}$ Como señalamos anteriormente, no son desconocidos los casos extremos en que la obra se imbrica comercialmente en una colección dirigida a los niños y las estadísticas muestran posteriormente que el texto ha sido leído tanto por adultos como por niños. Es el caso de obras como Manolito Gafotas de Lindo o Harry Potter de Rowling, libros, sobre todo este últi-

4 Utilizaremos esta denominación acuñada por Viala (1987) para referirnos a todos aquellos adultos que por razones diversas desempeñan las funciones de intermediarios: maestros, padres, críticos, etc. 
mo, que están suponiendo una revolución desconcertante en el mercado editorial (cf. Fernández, 2000b: 14-15). Hasta aquí hemos hablado de casos extremos; sin embargo, es necesario reconocer que un adulto debe encontrar en el texto infantil ciertos elementos que cuenten con él como cooperador textual para que le resulte atractivo en el momento de la lectura. ¿Qué claves esconde el texto narrativo infantil para posibilitar esa doble recepción?

Las variaciones, pues, en el proceso de transmisión son harto considerables si se comparan con el de la literatura para adultos. En lo que atañe al proceso de emisión, existe también la posibilidad de que se editen los llamados libros de encargo a instancias de las necesidades del mercado, entendiendo este sustantivo en un sentido muy laxo (instituciones, escuela, etc.). Si bien esto se puede producir en la literatura para adultos, el fenómeno es mucho más frecuente en la literatura dedicada a los niños. Sin ánimo de dilatarnos en este punto, puesto que no es un procedimiento exclusivo de la literatura infantil, es conocido cómo en los años noventa algunas colecciones nuevas se inauguraban con firmas ya consolidadas en el ámbito adulto. ${ }^{5}$

Hasta ahora hemos expuesto el esquema de transmisión de la obra literaria infantil, soslayando el esquema de comunicación interna que nos presenta la narrativa.

Conviene detenerse en el esquema interno de comunicación, porque, sin duda, en él radica la clave de interpretación del discurso que nos ocupa.

Tomando como referencia las pautas que ofrece Spang (1991: 74) e introduciendo ciertas modificaciones, podemos presentar el siguiente esquema:

\begin{tabular}{|c|c|c|}
\hline $\begin{array}{c}\text { Autor real-Autor } \\
\text { implícito-Narrador }\end{array}$ & $\begin{array}{c}\text { E/R fig. E/R fig. } \\
\text { Narratario }\end{array}$ & $\begin{array}{c}\text { Lector implícito- } \\
\text { Lector real }\end{array}$ \\
\hline
\end{tabular}

5 Nos referimos, por ejemplo, a las obras que marcaron el comienzo de la colección Alfaguay, colección en la que participaron, además de Lindo, autores como Montero o Madrid, todos ellos avalados casualmente por una trayectoria conocida por el público adulto, trayectoria que a su vez ejercía las veces de reclamo publicitario. 
Nos parece de vital importancia insistir en la presencia de los implícitos y en el narrador y narratario porque, una vez más, podemos acercarnos a la esencia de la narrativa infantil. De manera intuitiva, el lector tiende a identificar al narrador con el autor, aspecto contra el que llaman la atención estudiosos como Kayser (1985: 51) o Barthes (1966: 34). La reivindicación del autor surgió precisamente en el marco de las corrientes norteamericanas ${ }^{6}$ en un intento de frenar los esfuerzos por difuminar la figura del narrador. Primero Forster (1983) y, después, Booth (1974) trataron de salvar los fueros del autor y discernir de este modo entre las dos labores. Nace así el concepto de autor implícito, que se distingue tanto del autor real como del narrador. Según Booth (1974: 63, parte II), el autor implícito es la imagen que el autor real proyecta de sí mismo dentro del texto; esta imagen no tiene que coincidir con la del narrador $y$, a veces, entra en sutil contradicción con este. El autor implícito sienta las normas que rigen el funcionamiento del relato y su interpretación, así como subsidiariamente establece el sistema de valores que debe desentrañar su correlato en el sistema de comunicación literaria, que no es otro que el lector implícito, en la terminología de Iser, o lector modelo, en la de Eco. Nos decantamos por esta última puesto que en ella el concepto se define como una estrategia textual mientras que el término acuñado por Iser alude a la dependencia del acto de lectura. ${ }^{7}$

Nos hemos extendido en la aclaración y definición de estos términos porque creemos que los implícitos vienen a explicar en gran medida la historia de la narrativa infantil, y por extensión de la literatura infantil, desde sus orígenes a nuestros días, tal como sostiene Wall (1991). No hay que olvidar que partimos de una recepción dual que se materializa especialmente en un lector implícito o lector modelo. Sostenemos asimismo que el autor y el lector implícitos no sólo aparecen en el texto, en el transcurso de la narración, sino que también se reflejan en los paratextos.

6 Nos referimos a investigadores como Lubbock (1957), Friedman (1955), Schmid (1973), etc., que defendieron la posibilidad de un relato sin narrador.

7 A lo largo de la exposición utilizaremos, en algunos casos, la terminología de Iser para mantener formalmente el paralelismo con el término de autor implícito y señalar que los dos términos se desarrollan en el mismo nivel diegético. Quede claro, no obstante, que somos partidarios de la definición que de este concepto proporciona Eco. Utilizaremos, no obstante, el término de lector textual por la aproximación de este concepto al generador de tal instancia, que no es otro que el propio texto. 
El binomio narrador/narratario adquiere también importancia en la narrativa infantil de nuestros días por la transformación que ha sufrido en los últimos tiempos. Y ya adelantamos que la perspectiva desde la que el narrador se enfrenta al mensaje es uno de los rasgos más característicos de la narrativa infantil de los últimos años del siglo XX y principios del XXI.

Con el ánimo, pues, de analizar desde el punto de vista comunicativo el discurso narrativo infantil de finales del XX, principios del XXI, estudiaremos cómo se va construyendo el doble receptor tanto desde el punto de vista textual como desde la perspectiva paratextual.

\subsection{Los paratextos no verbales}

En los últimos tiempos la edición de libros infantiles ha ampliado sus técnicas de presentación con la incorporación de nuevos materiales y nuevas formas de compaginar texto e imagen con el desarrollo de la historia, de tal forma que, en algunas ocasiones, se ha llegado a crear un tipo nuevo de libro difícil de clasificar por el momento. Por otra parte, no son ajenos efectos de sonido, movimiento o iluminación en ediciones como las que acabamos de mencionar. Recordamos a este respecto libros como ¿Dónde está el osito de Kiper?, de Inkpen. En esta obra el osito de Kiper, un perro, se ha escondido y hay que buscarlo en los diferentes lugares que la historia presenta. Finalmente, el osito se encontrará leyendo un cuento con una linterna que, por supuesto, se enciende cuando el lector lo descubre debajo de una manta. Con ello queremos exponer que nos adentramos en un campo cuyo análisis desborda los límites de la crítica literaria tradicional (cf. Lobato, 1996). Así, por ejemplo, obras como El cartero simpático de los hermanos Ahlberg superan todos los límites de la edición al uso. Se trata de una historia compuesta por varios episodios basados en cuentos populares que funcionan como hipotextos enlazados por la figura de un cartero que va repartiendo misivas a los personajes de los diversos cuentos. Cada carta constituye un ejercicio de estilo diferente. Así, la primera es una invitación de cumpleaños que con letra manuscrita envía Ricitos de Oro al osito pequeño. La segunda es un texto publicitario que un almacén manda a la bruja de la casita de turrón; la tercera es una postal firmada por Jack, el de las habichuelas mágicas, desde un lugar en el 
que disfruta de unas vacaciones extremadamente lujosas y está dirigida al gigante de su cuento; incluso unos abogados redactan una carta en estilo jurídico para desahuciar al lobo que se encuentra viviendo en la casa de la abuela de Caperucita Roja. El libro se convierte en un juego tanto textual como visual, juego que se acentúa todavía más en la continuación de este libro titulada El cartero simpático en Navidad, donde aparecen juegos como puzles que acaban deshaciéndose. El receptor para acceder a estas obras debe conocer los textos tradicionales que funcionan como hipotextos, además de interpretar las parodias que se producen en la imitación de la actualidad de los diferentes estilos:

MÁS, MENOS Y MUCHOS ABOGADOS, S. A.

Edificio Mercurio, Calle del Que Venga, Tfno. 12345

Estimado Sr. Lobo:

Le escribimos en nombre de nuestra clienta, la señorita Caperucita Roja, a propósito de su abuela. La señorita Caperucita Roja nos dice que está usted ocupando la cabaña de su abuela y se pone sus ropas sin el consentimiento de dicha señora.

Sírvase tomar buena nota de que si esta situación continúa avisaremos al Leñador Mayor y si es preciso a todos los hombres del rey.

Por otra parte, debemos informarle de que los Sres. Tres Cerditos, S. L., están firmemente resueltos a ponerle un pleito por daños y perjuicios. Su oferta de compartir las ganancias en un robo de coles o lechugas ha sido desestimada, y no le servirá de nada perseverar en su presunta actitud.

Suyo afmo.

H. Más. (El cartero simpático)

Descubrimos en este fragmento un remedo del estilo jurídico teñido de ironía que nos lleva a contemplar una vez más una doble recepción. Por una parte, la "ensalada» de personajes de los cuentos tradicionales nos hace pensar en un lector infantil atraído por lo que supone una ruptura de su horizonte de expectativas a través del juego transtextual. Por otra parte, los nombres de los abogados, las expresiones propias del lenguaje jurídico, la ruptura de fronteras entre la realidad y la fantasía, el anacronismo parecen dirigidos al deleite de los adultos que, en última instancia, son los que recomiendan o facilitan la lectura del libro. Nos encontramos, pues, ante la posibilidad de ese doble lector modelo. El diseño de los sobres, el tipo de letra utilizado en cada una de las misivas, la composición estructural de las cartas, el detalle de la ilustración del contenido de las mismas, nos acercan a una edición muy cuidada y coherente desde el punto de vista plástico. 
Obras como la que acabamos de comentar someramente solicitan perentoriamente que los sistemas no verbales y, sobre todo, la ilustración salgan del ostracismo al que han sido condenados y se les confiera la importancia que, sin duda, les es debida desde los estudios tanto literarios como gráficos.

Como se desprende de lo que hemos expuesto hasta ahora, lo más adecuado a la naturaleza del objeto de estudio es la adopción de un modelo ecléctico (Lluch, 2003a y 2003b) en el que se atienda al discurso y a los factores socioculturales que lo condicionan, además del análisis de los textos y paratextos, puesto que estos últimos contribuyen a identificar por su recurrencia el concepto de colección, decisivo en la narrativa infantil, además de constituir un primer contacto de lectura con el lector, fundamentalmente con el lector o mediador adulto.

Los paratextos que mayor importancia tienen en la literatura infantil son los que se agrupan para diferenciar la colección: el tamaño, la portada, la ilustración, los anagramas de la colección, los indicadores de edad... En definitiva, los paratextos son concebidos, por una parte, como una guía para la comprensión y, por otra, como un procedimiento de identificación, además de crear pautas para la interpretación.

\subsubsection{La ilustración}

Uno de los elementos paratextuales que se presenta en este momento como fundamental es la imagen, la ilustración en el libro infantil y juvenil.

La ilustración adquiere en nuestros días una importancia sin precedentes ya que el destinatario del discurso narrativo infantil, que, a su vez, funciona como estrategia generadora del mismo, se identifica con un tipo de lector muy familiarizado con los sistemas audiovisuales que se mueve con soltura entre la fragmentación, la rapidez y la interactividad.

Genette (1987: 373) se refiere a la ilustración como uno de los paratextos más habituales en la obra literaria y de contenido inasible. Aun compartiendo con Genette la carencia de formación en el ámbito de las artes plásticas, entendemos que nuestro cometido en este momento no es juzgar la calidad estética de las ilustraciones o de las técnicas utilizadas sino definir cuál es la función de este elemento paratextual en el marco del discurso narrativo infantil: 
[...] quizá lo menos importante del trabajo de ilustración de los libros es la técnica o el procedimiento con el que se han realizado y sí, en cambio, la interrelación entre este componente y el texto, así como la adecuación de ambos al soporte y sus dimensiones (Ventura, 2004: 3).

Lewis (1999: 84) se refiere a tres formas de analizar el libro-álbum: la pedagógica (Obiols, 2004), que se centra en la comprensión; la estética, que se centra en el análisis de la imagen —la ilustración (Lartitegui, ${ }^{8}$ Moebius 1999; Calatayud, 2000; Colomer, 2002c; Pertínez, 2002)—; y la literaria -el libro-álbum es de naturaleza bipartita; es inevitablemente plural- Lo que a nosotros nos interesa no son los dos primeros aspectos sino el tercero, porque es ahí donde radica la especificidad del discurso.

Ciertamente, cada vez es mayor la atención que se está prestando en España a la imagen que suele acompañar a la palabra en el libro infantil (cf. Pertíñez, 2000: 401-407; Hidalgo, 2000: 69-74, y 2001: 51-60). Prueba de ello es la frecuente aparición de artículos de estudio y de opinión dedicados a la ilustración en revistas como Cuadernos de Literatura Infantil y Juvenil, Peonza, Babar, Primeras Noticias y en otras publicaciones periódicas que versan sobre el mundo de la literatura infantil. ${ }^{9}$ Sirvan como ejemplo de la importancia que se le está reservando a la ilustración en el marco del discurso literario infantil los últimos estudios de Díaz-Silva (2002), Obiols (2004) o García Padrino (2004) y, en otro orden, la publicación del Libro Blanco de la ilustración gráfica en España (2004), la edición de catálogos de ilustradores —desde Ilustradores españoles (1983) hasta Mira qué te cuento (2004), pasando por El texto iluminado (2002)—, además de la crea-

8 Agradezco a la autora haberme facilitado la consulta de La mirada consciente, aportación que, en estos momentos, se encuentra en prensa.

9 Por otra parte, se han editado catálogos de ilustradores españoles como el llevado a cabo por el INLE en 1982; desde el año 1958 se convoca el premio Lazarillo para ilustradores, premio que supuso una puerta abierta para la posterior convocatoria de otros muchos de ámbito nacional e internacional como el Andersen de ilustración, nacido en 1966. Incluso las editoriales están reconociendo la importancia del código de la imagen a través del cuidado de las ediciones y de la creación de premios como el Apel-les Mestres de la editorial Destino (cf. Jufresa, 1993: 33-35) o el Austral Infantil concedido por la editorial Espasa-Calpe y el Internacional de Ilustración a cargo de la editorial SM. Además, es ya obligada la presencia de los ilustradores en las jornadas y congresos dedicados al libro infantil, a la literatura infantil. Valgan como ejemplo las comunicaciones y ponencias dedicadas al motivo que nos ocupa en las Séptimas Jornadas de Bibliotecas Infantiles, Juveniles y Escolares celebradas en junio de 1999 en Salamanca o en el X Curso de Verano de Literatura Infantil organizado por la Universidad de Castilla-La Mancha en julio de 1999. 
ción por parte del Instituto Virtual Cervantes de la página titulada Cien años de ilustración infantil (2004). Si el mundo anglosajón ${ }^{10}$ constituye un ejemplo de la importancia que se le ha reservado a la ilustración de libros infantiles, en España es en la última década del siglo XX cuando se comienza a concebir el libro infantil o juvenil como un compendio de códigos y se empieza a conocer y a estudiar más de cerca a ilustradores de libros infantiles. ${ }^{11}$ De tal manera que en los años ochenta no fueron pocos los encuentros nacionales e internacionales en los que se hablaba de una «Escuela Española de Ilustración» que englobaría a todos los creadores que irrumpieron en el mercado editorial con el famoso boom de los años setenta, tales como Pacheco, Solé, Balzola, Boix, Calatayud, Gusti, Ginesta, Del Amo, Ruano, entre otros, aunque Balzola (1992: 8-15), Ruano (1992: 16-20) o Pacheco (1993: 18-29) negaran la existencia de tal escuela frente a la defensa que de esta hizo Lobato (1992: 14-22) en un espléndido artículo. Con escuela o sin ella, la ilustración ha tomado carta oficial en el marco de las disciplinas artísticas y, por ende, en el ámbito de la literatura infantil y juvenil.

Superadas ya las antiguas rencillas, a las que alude Armijo (1991: 1619), que separaban al escritor del ilustrador, siempre mediatizados ambos por la figura del editor, hoy es una realidad la consideración inexcusable del ilustrador en el libro infantil.

De este modo, Solé en una entrevista realizada por Castillo definía acertadamente la labor del ilustrador:

—Así, la ilustración ha de estar al servicio del texto.

- Sí. Siempre he tratado de adaptarme al texto, a mi manera de verlo claro, otro ilustrador seguramente lo haría de otra forma. Siempre he tratado de expresar aquello que el relato me ha sugerido (Castillo, 1994b: 44-49).

En este aspecto abunda Sendak (Lorraine, 1977: 152) cuando define el papel del ilustrador como «un participante, alguien que tiene algo que decir tan importante como el autor del libro, en algunas ocasiones más importante, pero nunca el eco del autor».

10 Cf. Kiefer, 1983; Moss, 1981; Crago, 1983; Parmegiani, 1985: 49-72; Hunt, 1995; Obiols, 1995: 7-20; Obiols, 2004: 85-122.

11 En lo que respecta a la historia de la ilustración infantil, el trabajo de García Padrino (2004) es de referencia inexcusable en la consolidación de este ámbito de estudio. 
En este orden de ideas, De Horna y Wensell resultan taxativos en sus afirmaciones:

No hay ilustración que se baste sí misma porque su estado natural está en el libro, acompañando al texto (De Horna, 1995: 65).

Quede claro que todo libro ilustrado es la obra conjunta de dos autores: el autor literario, que se expresa mediante la palabra escrita, y el autor de imágenes, que, aun basándose en el texto para crearlas, es libre de interpretar sus sugerencias, de ampliarlas, de enriquecerlas, de poner en relieve ciertos aspectos de su interés y de ofrecer, en fin, una aportación artística personal (Wensell, 2000: 152).

Dupont-Escarpit (1999: 24-26), tratando de establecer la especificidad de la ilustración, determina unas pautas para su interpretación que resultan esclarecedoras. En primer lugar, señala que la ilustración implica una obra previa,

con la que se debe establecer una comunicación para traducirla e interpretarla a fin de generar una obra más compleja y más rica que, a su vez, establecerá una comunicación a diferentes niveles con el joven lector.

Continúa la citada autora (1999: 25) comentando que la ilustración contemporánea no se queda al margen de las grandes corrientes artísticas y se muestra como autónoma en el ámbito de las artes gráficas ("Arte mayor o arte menor», 1998: 13-18). De este modo, se le ofrecen al lector dos tipos diferentes de lectura, la del texto y la de la imagen que no debe ser juzgada a la luz de criterios plásticos únicamente.

Así pues, de lo expuesto se infiere que la ilustración es una forma de escribir el relato, otro modo de narrar la historia.

No entraré a analizar cuál es el papel de la ilustración en el proceso de lectura, si lo favorece o contribuye a distorsionarlo, si es conveniente que aparezca en los libros destinados a niños mayores, etc. ${ }^{12}$ Lo que nos interesa es comprobar en qué medida la ilustración se incorpora al discurso narrativo, lo complementa y se convierte en parte indispensable del mismo, de tal forma que no es posible interpretar el texto sin la presencia

12 Cf. a este respecto Durand y Bertrand, 1975; Danset-Léger, 1980; Moebius, 1986; Spink, 1990; Despinette, 1993; Monográfico de la revista Peonza, 1996. 
de los recursos no verbales. La ilustración adquiere en nuestros días una importancia sin precedentes ya que, como hemos comentado anteriormente, el lector actual es un lector familiarizado con los sistemas audiovisuales. Cabe suponer, pues, que la narrativa actual debe incorporar a su discurso a un receptor con una competencia previamente adquirida en la lectura de imágenes, aunque, en algunos casos, la ilustración fagocite el texto y el discurso se convierta en una propuesta poco consistente desde el punto de vista literario (Colomer, 2000: 8).

\subsubsection{Las funciones de la ilustración}

La relación entre texto e ilustración y el papel que esta desempeña en función de la palabra a la que acompaña es una de las primeras cuestiones que se plantea en los estudios que versan sobre este tema.

Obiols (2004: 35-40) atribuye cinco funciones a la ilustración:

Mostrar lo que no expresan las palabras; redundar en el contenido del texto; decorar y embellecer el texto; captar y mostrar parcelas del mundo que nos rodea; enriquecer a quien las observa (Obiols, 2004: 35).

García Padrino (2004: 19-20) incorpora, además, la función de servir de mediador privilegiado entre el creador literario y su receptor natural, «a partir de una auténtica recreación de los elementos básicos en un determinado texto literario».

Nada tenemos que objetar a la consignación de estas funciones. Sin embargo, creemos que es necesario contemplar la dimensión pragmática de este código. Desde esta perspectiva, la imagen ha venido a sustituir en una sociedad como la nuestra, la del siglo XXI, que requiere, como decíamos antes, nuevas formas de oralidad, a los matices del narrador. La literatura infantil es concebida desde la escritura y no desde la oralidad, desde la recepción individual y no colectiva, desde la lectura y no desde el auditorio.

Marantz (1999: 10) hace referencia a esta función cuando menciona que todos los libros-álbum narran cuentos y se refiere al origen oral de todas las historias. La voz, y con ella sus matices, se pierde en la escritura y asimismo desaparece la manera de transmitir de cada cuentacuentos. De este modo, el ilustrador reemplaza al narrador tradicional y las imágenes se convierten simbólicamente en la voz que comunica alguna de las pro- 
piedades especiales del significado que con frecuencia no puede hacer el lenguaje. Por tanto, la incorporación de la ilustración al discurso del siglo XX corresponde a una nueva forma de contar acorde con el nuevo receptor.

¿Cómo construyen el significado texto e imagen? A través de la interpretación. El ilustrador interpreta el texto y se convierte en otra de las estrategias discursivas generadoras de significados. El diálogo entre el texto y la imagen es uno de los factores que define el procedimiento de creación de escritor e ilustrador.

\subsubsection{El libro-álbum}

Es necesario distinguir entre libro-álbum y libro-ilustrado. La diferencia entre uno y otro no depende de la cantidad de ilustraciones sino que depende del concepto del que se parte (Shulevitz, 1999: 132). El álbum es un género editorial exclusivo y único.

Greene (1999: 13), al tratar de la obra de Caldecott, insiste en la interpretación que este realizó del texto añadiendo elementos nuevos al cuento. Por esta razón, Sendak atribuye a Caldecott la invención del libro-álbum.

Los precedentes de lo que hoy consideramos «álbum» los podemos encontrar en el siglo XIX en el Der Struwelpeter de Hoffmann, en Alicia en el pais de las maravillas de Carroll o en A Apple Pie de Greenaway. Ya en los inicios del siglo Xx hay que citar los Albums du Père Castor de Faucher y, sobre todo, la Historia de Babar de Brunhoff. Es en los años sesenta cuando se puede situar el nacimiento del álbum tal como lo concebimos en la actualidad (Colomer, 1998: 90; Durán, 1999: 78). En la década mencionada se advierte una transformación en el ámbito intelectual: cultura de masas, sociedad de consumo desembocan en un pensamiento relativista (Barthes, Russell, Wittgenstein) donde se prioriza lo posible sobre lo real. Así se refiere a este momento y a su influencia en la génesis del álbum Durán:

Los nuevos modos de producir una cultura de masas, el lenguaje cinematográfico, la publicidad, etc., aportaron nuevos modos no sólo de recibir un mensaje, sino, sobre todo, de elaborarlo. En el álbum encontraríamos las aportaciones semióticas de los nuevos lenguajes, fundiéndose en una polifonía de significado. Que los primeros álbumes que instauran la revolución semiótica dentro de la comunicación infantil provengan de diseñadores publicitarios no es, creo, fruto del azar (Durán, 1999: 79). 
En el álbum, texto e imagen no sólo se complementan sino que crean un juego de perspectivas, de alusiones metaartísticas, de mundos posibles, de tal modo que lo convierten, como señala Colomer (1998: 91), en el primer tipo de libro infantil que ha incorporado un cierto tipo de ruptura de las técnicas literarias habituales que corresponde «a lo que se ha analizado por la crítica reciente en términos de posmodernidad». ${ }^{13}$ Por otra parte, el álbum, al ofrecer un producto pluridisciplinar, se ha convertido en uno de los emblemas de lo posmoderno.

En definitiva, un libro-álbum, a diferencia de uno ilustrado, es concebido como una unidad, una totalidad que integra todas sus partes designadas en una secuencia de interrelaciones.

El concepto de libro-álbum, término que viene a coincidir con lo que en el mundo anglosajón se denomina picture books (cf. Shulevitz, 1996: 238) ha sido definido por Durán con las siguientes palabras:

[...] el álbum es, sobre todo, un trabajo polifónico donde el soporte físico y la narratología textual y visual concuerdan afinadísimamente. Este acorde puede estar al servicio de cualquier tipo de relato (fantástico, documental, cotidiano...) y dirigirse a cualquier tipo de público, por poco que éste sea sensible a la recepción de un producto pluridisciplinar que, a mi entender, es cada vez más emblemático de lo que podría llegar a ser la cultura postmoderna, es decir, de aquella cultura que según José Antonio Marina, Lyotard, Eco o Barth, utiliza el ingenio y la fabulación, la indefinición y la indeterminación, la ambivalencia y el pensamiento simbólico para comunicarse. [...] En el álbum participan los mismos elementos que se encuentran en las demás modalidades de libro, pero con características propias: la proporción, tanto en superficie como en intensidad narrativa de las imágenes es, por lo menos, igual a la del texto o en infinidad de casos claramente superior; la estructura secuencial de sus páginas resulta básica tanto para su carga narrativa como para la lectura contemplativa. Se prioriza en él —y es aquí donde la secuenciación resulta esencial— la recepción del mensaje visual (sin imagen el texto, si lo hay, perdería fuerza y concreción, aunque hay que tener en cuenta que, en los casos óptimos, el texto opera como «revelador» de la imagen...) (Durán, 1999: 79).

Justificamos la extensión de la cita porque nos parece de gran importancia señalar dónde se encuentran los límites que separan el libro ilustrado de lo que actualmente recibe la denominación de álbum. Insistiendo en el esfuerzo de establecer los límites del concepto que nos ocupa,

13 Cf. para este concepto en lo que se refiere a la narrativa infantil, Moss, 1992. 
Dupont-Escarpit (1996: 16) define el álbum ilustrado como «una obra en la que la ilustración es esencial, predominante, y el texto puede estar ausente o presente al cincuenta por ciento». Dupont-Escarpit descubre varios elementos en esta clase de libro: el texto, que desarrolla temas muy diversos; la imagen, que camina desde la expresión hasta la experimentación artística; la relación entre el texto y la imagen y, por último, el formato que responde a cubiertas y contracubiertas de material duro, grandes dimensiones y detalle en la cuidada presentación. Si bien estamos de acuerdo en la mayor parte de los casos con definiciones como las que hemos expuesto, creemos necesario concretar aspectos como los que conciernen a la proporción y al formato. En lo que respecta a la proporción, no parece acertada la vinculación del discurso literario a la ausencia total del texto. Creemos que en los casos en que el texto no aparece, sería conveniente utilizar la denominación de «libros de imágenes» puesto que, si no, se corre el riesgo de superar los límites de lo literario. En cuanto al formato, los criterios editoriales dictan las leyes de mercado y, salvo contadas excepciones - Kókinos, Kalandraka, entre otras - se tiende a abaratar el precio de los ejemplares sacrificando las grandes dimensiones, la calidad del papel y de las portadas en aras de tiradas más rentables. ${ }^{14}$

No estamos de acuerdo con muchas de las observaciones realizadas por Dupont-Escarpit porque pensamos que no se trata del predominio de la imagen sobre el texto sino que como ya hemos señalado es cuestión de concepto. En este sentido, es necesario aclarar ciertos parámetros para aproximarnos a la definición de lo que nosotros vamos a llamar libro-álbum. Las relaciones entre palabras e ilustraciones varían desde una relación de obvia

14 Constituyendo el álbum una modalidad que ofrece muchas posibilidades para formar la competencia literaria del receptor infantil, no podemos soslayar, sin embargo, las dificultades por las que está pasando desde la perspectiva del mercado. La edición material de aquel es costosa desde el punto de vista económico y entraña un riesgo que no todos los editores están dispuestos a asumir. Por otra parte, todo editor conoce que en fechas de mayores ventas, como son las Navidades, el álbum ilustrado debe competir en inferioridad de condiciones con productos de consumo apoyados por una ingente campaña publicitaria, tales como los álbumes que desarrollan las historias de Disney. Los editores, por tanto, junto a los libreros, a los bibliotecarios y a los maestros, deben intentar apoyar este sector minoritario de una gran calidad que no acaba de encontrar su lugar en las grandes editoriales si no es a la manera de colecciones que contribuyen a prestigiar la labor editorial, posibilidad que los pequeños editores ni siquiera pueden contemplar (cf. Roehrich-Rubio, 1996: 36-37). 
congruencia hasta una de alta ironía. Así, en su más alto grado de experimentalidad, requieren de un alto grado de tolerancia por parte del lector (Donan, 1999: 35). Lewis (1999: 86) menciona que la incesante interacción entre palabra e imagen es una de las dos razones por las que la forma de los libros-álbum tiene una extraordinaria apertura y sensibilidad. Se trata, por tanto, de una concepción en la que la imagen y el texto responden a la creación del discurso de tal modo que si desapareciera uno de los dos códigos, desaparecería también la obra. Una vez ilustrado, ningún libro queda inmune a la influencia de la imagen visual. Y esta afirmación de Lewis (1999: 86) nos acerca a la realidad de lo que llamamos libro ilustrado, que parte de un concepto diferente. En el libro ilustrado (Diecisiete cuentos, de Nesquens; El grito de la grulla, de Alonso; Hasta (casi) cien bichos, de Nesquens; Días de Reyes Magos, de Pascual. Figs. 1, 2, 3) el texto funciona como guía de la historia y la imagen ofrece una interpretación, entabla un diálogo con el texto, ofrece claves de desarrollo de la trama, pautas al lector para construir el significado y, sin embargo, la relación de interdependencia es menor, aunque, evidentemente, la obra no sería la misma. También existen, eso sí, casos fronterizos como el de El grito de la grulla, en el que todo lo referente a la papiroflexia no se puede imaginar sin las ilustraciones.

Por otra parte, la especial interrelación que se produce en el discurso que nos ocupa entre texto e imagen implica su grado de experimentalidad y su vinculación a la posmodernidad. El receptor infantil acepta mejor que el adulto la experimentalidad por su menor enciclopedia o intertexto y, por tanto, como señala Donan (1999: 35) es un receptor más abierto a nuevas propuestas. Los autores parten de las formas más simples de la narración, pero utilizan recursos que inician la posibilidad de desviarse de ellas, recursos que ayudan a los niños a ir más lejos en su competencia literaria. La relación entre texto e imagen es la que provoca el carácter experimental del álbum y la especial consideración del receptor y de su aceptación de la experimentalidad.

\subsubsection{3. ¿Cómo interactúan imagen y texto y construyen los significados en el libro-álbum?}

El libro-álbum, tal como lo hemos definido, tiene mucho parecido con la novela caracterizada por Bajtin como polifonía de voces y lenguajes 
tejidos con habilidad para conformar una totalidad que se desarrolla constantemente adquiriendo nuevas formas. La novela posee estas características porque es la única forma de arte verbal que entra en contacto directo con la naturaleza inacabada e incompleta de la vida contemporánea. En este sentido, se refleja el espíritu de la posmodernidad más que en ningún otro género (Lewis, 1999: 87).

Graciela Montes (1999: 106) habla así de la posmodernidad:

No están de moda las lecciones. No hay nada en lo que creamos lo suficiente como para convertirlo en lección sabida. Al parecer creemos sólo en lo efímero, lo fragmentario, lo leve.

Lo metaficcional es una de las características más vinculadas a la posmodernidad, el juego con las convenciones, propio de la metaficción, se adecua a las características que hemos mencionado como esenciales de la etapa con que se cierra el siglo XX y se inaugura el XXI. La carta de la señora González (fig. 4), de Lairla y Lartitegui, ejemplifica, como pocos álbumes, este tipo de juego experimental en el que se desdibujan las fronteras entre lo real y lo onírico, y la palabra y la imagen establecen un entramado de sentido, basado en la sugerencia de los dos códigos, digno de un análisis pormenorizado (Carranza, 2002).

La metaficción es también una de las características que más desconcierto ha sembrado en el panorama de la literatura infantil y juvenil. En esta línea, los estudios de Silva-Díaz han contribuido a sembrar el orden con los mecanismos de medida de las desviaciones metaficcionales.

Del mismo modo, la ruptura de la frontera narrativa, lo que Genette denominaba metalepsis, se encuentra en este tipo de obras. Así, El libro que tenía un agujero (fig. 5), de Domitille y Héron, presenta un juego de niveles ficcionales con el agujero como elemento de transición entre los diferentes estadios.

Si una de las características del discurso narrativo infantil es la intertextualidad, el libro-álbum ofrece la posibilidad de jugar con los códigos y complicar las propuestas hasta el extremo. Así, Donde viven los monstruos (fig. 6), de Sendak; el Libro de las M'Alicias (fig. 7), de Obiols y Calatayud; y Ahora no, Fernando, de Mckee, hacen gala del juego intertextual en el que se refleja el entramado de textos del que hablaba Kristeva, esta vez 
trasvasado al código pictórico (Moebius, 1999: 104). No es difícil adivinar en Max al pensador de Rodin; en el Libro de las M'Alicias la figura de la protagonista recuerda a la niña que dibujó Tenniel; en Ahora no, Fernando, el lector descubre, por ejemplo, que en la estantería del dormitorio de Fernando está Elmer, el elefante de colores.

Las ilustraciones, además, alertan sobre los errores del texto y, en realidad, nos hacen disfrutarlo. La distancia entre la historia que cuentan las palabras y la historia que cuentan las ilustraciones es lo que hace al libro interesante (Nodelman, 1999: 119).

Mamá fue pequeña antes de ser mayor (fig. 8), de Larrondo y Lamartine, se basa en las contradicciones entre texto e imagen. Cada imagen expresa lo contrario de lo que transmite el texto. El lector debe, pues, inferir el significado de la colaboración entre los dos códigos. La ironía - basada en la contradicción que se establece entre los dos códigos- está presente en todas las páginas. El poder de sugerencia y de crítica de este álbum construye a la perfección un doble lector, el adulto y el infantil.

En nuestros días el juego de texto e imagen se ha complicado hasta llegar a obras como Los osos de Ni-se-sabe, de Varvasovsky, narración en la que la ilustración marca el desarrollo del texto o ¡Papá! (fig. 9), de Corentin, obra en la que el juego de perspectivas, trabajado desde el texto y la imagen, sorprende irónicamente al receptor, siempre bajo un formato cuidadísimo. Asimismo, en la línea del juego entre sueño y realidad se desenvuelve la historia de iiiPapááá....!!! (fig. 10), de Cano y Giménez, y, en esta línea, cómo no comentar el juego hipertextual que se establece en uno de los álbumes que la crítica ha incorporado a la lista de los 100 mejores libros para niños del siglo XX español (Fernández, 2000a): el Libro de las M'Alicias, de Obiols y Calatayud. En esta obra, utilizando como hipotexto el libro de Lewis Carroll, se juega con el lenguaje creando mundos oníricos diferentes no exentos de cierto componente crítico y se destruye simultáneamente la realidad en las ilustraciones de Calatayud. Otra obra reseñable en este aspecto es Abuela de arriba, abuela de abajo, de De Paola.

Por otra parte, las ilustraciones nos muestran en detalle cómo se ve un lugar específico en un momento determinado, fuera del tiempo, eso sí (Nodelman, 1999: 121). 
La ilustración puede suplir, en ocasiones, los recursos narrativos del texto. No olvidemos que es otra forma de contar, otro código con resortes narrativos. ${ }^{15} \mathrm{Si}$ nos detenemos en la focalización o perspectiva, comentaremos más adelante cómo la focalización cero o falta de focalización es una característica textual que encontramos en el álbum (cf. Colomer, 1996a: 27; 1998: 90; Dupont-Escarpit, 1999: 25; Durán, 1999: 79, у 2002). Álbumes como Rosa Blanca (figs. 11 y 12), de Innocenti y Gallaz; De cómo Fabián acabó con la guerra (fig. 13), de Vaugelade; y 10 soldados, de Rapapport; El soldado y la niña, de Sierra y Piérola, o El libro de la paz, de Stilton, muestran un texto con un narrador no focalizado que controla el texto desde la omnisciencia propia de la narrativa tradicional, además de presentar las marcas propias del discurso tradicional (cf. Pisanty, 1995: 60 y ss.), en la línea del juego intertextual muy propio de las obras de finales del siglo XX.

Había una guerra. Todas las mañanas los hombres partían al campo de batalla. Los que volvían por la noche llevaban a los muertos y a los heridos. La guerra duraba desde hacía tanto tiempo que ya nadie recordaba por qué había empezado (De cómo Fabián acabó con la guerra, de Vaugelade).

Sin embargo, la incorporación de la imagen anula la falta de focalización del texto en algunos casos, puesto que es la ilustración la que se ocupa de la focalización de la historia narrada. Si el texto observa una ausencia de perspectiva desde la tercera persona, la imagen se encarga de lo que textualmente se conoce como la focalización actorial (Genette, 1989a: 252 y ss.). De este modo, la ilustración ofrece la perspectiva desde la que se contempla la acción, muestra al receptor desde dónde se narra, lo que se presenta a sus ojos y, en ocasiones, el narrador pierde la fiabilidad que desde el texto había adquirido. Díaz Armas (2002: 8) en un interesante artículo sobre la función de la perspectiva en la literatura infantil y juvenil, refiriéndose a la presencia de la misma en el álbum, señala el principio de economía textual que impera en este tipo de creaciones, puesto que la imagen presta informaciones que, de otra manera, debería explicar el texto.

15 En este sentido, nos ha sorprendido, por sus similitudes con el libro-álbum, la aplicación que de la teoría narratológica de Genette realizan Gauldreault y Jost (2001) en el análisis del relato cinematográfico. 
Uno de los mejores ejemplos de lo que acabamos de exponer lo proporciona Rosa Blanca, de Innocenti. En este álbum el traductor opta por un narrador que se define como heterodiegético, identificado con una tercera persona que comienza el relato desde la falta de focalización o focalización cero y camina paulatinamente hacia la focalización interna en la protagonista de la obra. El narrador se muestra claramente heterodiegético, focalizado en muchos momentos en el personaje protagonista:

Rosa Blanca vivía en una pequeña ciudad de Alemania. Sus calles eran estrechas, con fuentes antiguas y casas altas, sobre cuyos tejados iban a posarse las palomas. Un día, aparecieron los primeros camiones y muchos hombres se subieron a ellos. Llevaban uniformes y se saludaban. El alcalde Schroeder pronunció un discurso. Por todas partes, colgaban banderas de colores y los niños saludaban. [...]

Sin embargo, Rosa Blanca estaba cada vez más delgada. Entre toda la gente de la ciudad, el único que seguía estando gordo era el alcalde Schroeder, que continuaba pronunciando largos discursos. Pero la gente ya no era tan amable y, desconfiados, se vigilaban unos a otros. Rosa Blanca ocultaba la comida en la cartera del colegio y tenía mucha prisa al salir de la escuela.

La ilustración de este álbum se podría insertar en un estilo neorrealista, acorde con los años en los que se desarrolla la segunda guerra mundial, bajo una estética propagandística del régimen nazi que imprime un ambiente muy adecuado a la época en que se sucede la acción. Los colores utilizados por Innocenti corresponden a la gama de los verdes, marrones, pardos, es decir, a los tonos que definen una guerra y a los personajes que la protagonizan. Los únicos colores que difieren de la gama que acabamos de mencionar provienen de la vestimenta y del peinado de la protagonista. En cada una de las imágenes aparece Rosa Blanca luciendo una falda rosa, un abrigo azul y, lo más importante, un lazo rojo en el pelo, símbolo de la niñez vinculado, en esta obra, al personaje de Caperucita Roja en una referencia intertextual claramente identificable (Colomer, 1996b). ${ }^{16} \mathrm{El}$ lector comparte en cada ilustración la perspectiva desde la que la niña observa cuanto ocurre a su alrededor. El color rojo de su ropa y de su cinta contrasta con la falta de luz —incluso de vida - y la

16 No es difícil recordar, a este respecto, que la única nota de color que aparece en la película de S. Spielberg, La lista de Schlinder, viene de la mano de una niña que va vestida de rojo y que atraviesa la pantalla totalmente ajena al dramatismo de la situación que se narra. 
frialdad del ambiente parduzco en el que la historia se desarrolla. Conforme el aspecto demacrado y el hambre invaden los rostros y los gestos de los personajes, Rosa Blanca modifica su vestimenta y el rojo desaparece para ser sustituido por colores tan desvaídos como los de su entorno. Su pelo ya no luce ningún lazo; la niñez ha dejado paso a la madurez, y la inocencia perdida anuncia un final muy poco convencional vinculado a los colores violetas. ${ }^{17}$

En ese momento, otros soldados llegaban a la ciudad. Sus camiones y sus tanques olían igual y hacían el mismo ruido, pero sus uniformes eran de un color diferente y hablaban en un idioma desconocido. Con los soldados regresaron personas que habían desaparecido de la ciudad años atrás.

La madre de Rosa Blanca esperó mucho tiempo a su pequeña hija. En el bosque, los árboles se abrían en el claro y, poco a poco, ocultaron los restos de la alambrada. Había llegado la primavera.

En el texto, pues, la focalización actorial es fluctuante puesto que es la ilustración la que va mostrando al receptor tanto a la niña protagonista como lo que esta observa y percibe. De este modo, el receptor afronta la historia desde la mirada de una niña que no acaba de entender qué ocurre a su alrededor, que no sabe interpretar imágenes como las estrellas de los presos de los campos de concentración, que no termina de dotar de sentido a la tristeza de su entorno y que se convierte en una de las víctimas de un conflicto carente de toda justificación. Por otra parte, es destacable asimismo la ausencia casi total de lexemas relacionados con el campo bélico. Así pues, el lector infiere del contexto y de la imagen la situación a la que se refiere el discurso ya que el narrador no puede nombrar desde la perspectiva del protagonista aquello que este desconoce. La mirada infantil, una vez más, desempeña la función de mostrar al adulto las contradicciones propias de la realidad.

En otro estilo es reseñable el álbum de Piérola (No sé), en el que el juego de perspectivas se establece tanto en el texto como en la ilustración.

Si de juego de perspectivas y de complementariedad tratamos, no podemos dejar de referirnos a un álbum como el de Mckee, No quiero el

17 La utilización del peinado de las niñas protagonistas para simbolizar las diferentes etapas vitales por las que los personajes tienen que transitar es bastante común en la narrativa infantil. Valga como ejemplo Yo las quería, de María Martínez y Vendrell. 
osito (fig. 14), en el que el texto verbal conduce sólo la historia de dos niños y de sus respectivos ositos, mientras que la ilustración presenta y desarrolla varias historias que ocurren alrededor de los dos protagonistas. El juego de perspectivas que se establece es inusual, las imágenes son planas, en la línea del expresionismo, y el receptor experimenta la sensación de contemplarlo todo desde arriba, tal como lo pueden estar haciendo las madres de los dos pequeños.

Del mismo modo, Perro y gato (fig. 15), de Alcántara y Gusti, constituye un ejemplo del álbum de finales de los años noventa (Fernández, 2000a: 56-59). La edición es muy cuidada, con cubierta y contracubierta de cartón muy duro y el papel de color sepia, lo cual contribuye a crear una atmósfera muy tierna de acuerdo con la historia desarrollada. Diez composiciones a toda página y cinco sencillas conforman este álbum marcado por la dualidad contrapuesta que se advierte en el título. La ilustración corresponde a lo que Dupont-Escarpit (1996: 19) denomina «imagen narrativa»: Perro y gato cuenta la historia de un perro y un gato que son llevados a una casa a modo de regalos con motivo del cumpleaños de dos hermanos gemelos. Los animales, dada su condición de adversarios — como reza la sabiduría popular-, deciden ser enemigos y así se van sucediendo las faenas que se realizan mutuamente. Eso sí, la noche llega y se sienten muy solos, lejos de sus respectivas madres; lo único que les queda, pues, es acompañarse y sellar la paz:

El perro y el gato quedaron solos en medio de la oscuridad. Era la primera noche que pasaban lejos de su madre, y eso les hacía sentirse muy solos. [...] En medio de la oscuridad, cada uno vio brillar los ojos del otro. Sin pensárselo dos veces, se acercaron corriendo. Y acabaron, juntos y abrazados, debajo del sofá. Estando tan unidos, no les asustaba la oscuridad.

El texto, como se puede comprobar, es muy sencillo y lineal, con gran abundancia de distributivas de acuerdo con el tema de la narración. La ilustración acompaña al texto ampliándolo y matizándolo. Lo más relevante de la imagen, que, sin duda, contribuye a desarrollar un mundo afectivo que en el texto sólo queda sugerido, es el juego de perspectivas que en ella se trabaja. Cada composición observa una oposición física entre los dos animales, de tal forma que sólo en las dos últimas ilustraciones encontramos al perro y al gato unidos. Esto no constituiría un elemento relevante si no fuera por el hecho de que, en ningún momento, los ojos de los 
protagonistas dejan de estar comunicados. Las miradas, los ojos, son lo más destacable en una ilustración en la que la nota dominante es la ingenuidad e intenta aproximarse al lector por la vía de la «empatía emotiva», en palabras de Durán (1995).

Hemos mencionado anteriormente la importancia de la perspectiva en la imagen puesto que en todo momento la visión que se ofrece es la de dos animales en un mundo de personas. La realidad se contempla desde abajo hacia arriba. El perro y el gato no acaban de encontrar su lugar hasta que unen sus fuerzas y se refugian en la oscuridad debajo de un sofá.

El texto ocupa los márgenes de la ilustración, lo cual nos hace inferir que la fuerza narrativa de la obra se desprende de la ilustración. Los colores ocres, muy cálidos, contribuyen a acendrar la nota de ternura e ingenuidad que emana de la obra que adquiere su punto culminante cuando cae la noche y lo único que queda es la presencia de unos grandes ojos, amarillos otra vez, que buscan refugio para paliar su sensación de desamparo en un entorno azulado que confirma la frialdad que invade a los protagonistas.

Tanto el texto como la ilustración trabajan conceptos básicos y tópicos en lo que concierne a la historia que se relata: huesos/espinas de pescado; uñas/ladrido; leche/agua; en definitiva, perro/gato, con el juego intertextual que encontramos en la historia que alude a la frase popular (llevarse como el perro y el gato), muy conocida, por otra parte, en el mundo infantil.

El texto puede describir el tiempo y el espacio, mientras que las ilustraciones describen sólo el espacio. Las imágenes pueden retratar una serie de momentos en una secuencia, pero la historia que describen está fragmentada. Valga como ejemplo Cuando los borregos no pueden dormir (fig. 16), de Kitamura, obra en la que los viajes de los personajes y sus desplazamientos son expresados a través de las palabras que unen cada una de las imágenes.

En esta línea, aligera el contenido de las palabras, facilita visualmente el proceso de aproximación y sugiere mucho más de lo que ya está escrito. Así por ejemplo, en la obra Cuando los borregos no pueden dormir, de Kitamura, la ilustración complementa los vacíos creados por el texto y sólo a través de ella, por ejemplo en la presentación de la casa con muchas puertas, el lector puede sospechar que se trata de un juego entre la realidad y la fantasía propia del mundo onírico. En un momento dado Madejo, que 
así se llama el protagonista de la narración, descubre unos destellos luminosos en el cielo que lo aterrorizan. Él desconoce que se trata de platillos volantes, objetos totalmente familiares para los niños actuales, tal como lo muestra la ilustración que acompaña al texto. Otra cuestión digna de análisis en la obra citada es el juego intertextual que se produce tanto en el texto como en la imagen entre las andanzas del borrego Madejo y la vinculación del hecho de contar ovejas a la llegada del sueño.

De la misma forma, en la introducción de ¡Adiós, pequeño! (fig. 17), de los hermanos Ahlberg, el discurso reza de esta manera:

Había una vez un niño pequeño que no tenía mamá. Vivía completamente solo en una casa. Él solo se preparaba la comida y él solo se bañaba. Y hasta se tenía que cambiar los pañales él solo.

La ilustración, sin embargo, amplía el texto y ofrece más situaciones en las que el niño muestra su forzosa autonomía: fregar los platos, apagar la luz cuando se va a dormir, etc. La imagen, pues, apoya el texto, lo amplía y matiza ofreciendo detalles que de otro modo contribuirían a complicar el discurso verbal. Asimismo, el texto desempeña la función de guía de lectura de imágenes que, de otro modo, pueden desarrollar un discurso impreciso (Nodelman, 1988: 171).

Del mismo modo, se podrían comentar álbumes como Tú y yo, osito, de Waddell y Firth, o Porque te quiero..., de Teulade y Sarrazin.

En los últimos años, la ilustración caracteriza el discurso literario infantil por su adecuación al lector del siglo XXI, por una parte, y por la duplicidad de la recepción que implica, por otra. La imagen atrapa al adulto mediador convirtiéndolo en uno de sus receptores y los emisores así lo conciben como estrategia.

Obras como El erizo de mar, de Iela Mari; Pies para la princesa, de Da Coll; Operación J (fig. 18), de Nesquens y Gamón, o Los tres erizos (fig. 19), de J. Sáez Castán; Osos de cuento o No todas las vacas son iguales (fig. 20), de Ventura y Amargo; Enamorados (fig. 21), de Dautermer; El pie frito (fig. 22) de Calatayud; Siete ratones ciegos (fig. 23), de Young; Niña Bonita (fig. 24), de Machado; Ser quinto (fig. 25), de Jandl; A qué sabe la luna (fig. 26), de Grejniec y Jung, o El túnel (fig. 27), de Browne, constituyen ejemplos de lo que acabamos de mencionar. 


\subsubsection{Los pictogramas}

En los últimos años de la década de los noventa hemos asistido a la presencia en el mercado editorial de álbumes en los que no sólo la ilustración desempeña las funciones antes citadas sino que invade el texto para formar parte del mismo. Nos referimos a la técnica de los pictogramas que consiste en sustituir palabras básicas del texto por iconos que se refieren al concepto y que, en la mayor parte de las ocasiones, vienen explicados en la parte inicial o final de la obra a manera de diccionario. Colecciones, como las editadas por Bruño con el título de Cuentos de colores o SM en la serie Pictogramas están apareciendo en las librerías con bastante asiduidad. En los libros así construidos el ilustrador aparece en primer lugar en la portada y después el nombre del autor del texto.

¿Cuál es la finalidad de los álbumes de pictogramas? Creemos que el fin último es convertir la lectura en un juego en el que hay que adivinar el significado de los símbolos que allí aparecen. Por otra parte, la presencia de una imagen como significante viene a romper la arbitrariedad del signo lingüístico, algo a lo que el lenguaje infantil y el poético son muy proclives (Gili Gaya, 1972). En cierto modo, la lectura se transforma en una labor cooperativa que encierra un reto en cada página. Esa vertiente lúdica, estimamos, es la que fundamenta el atractivo de estas colecciones. En ellas se potencia el poder narrativo de la imagen hasta inmiscuirse en el propio texto y formar parte de él. Una vez más, como señala Colomer (1996: 27), la imagen se utiliza para fomentar la competencia literaria partiendo de que la capacidad del receptor infantil para acercarse a las imágenes se desarrolla con anterioridad.

En estos álbumes, se utiliza la letra cursiva entrelazada y el texto generalmente se supedita a la imagen como ocurre en la colección ideada por SM; por poner un ejemplo, remitimos a obras como El pirata despistado, de Hernández Aguiar y Lavarello, o Cosas de brujas, de Candel, Garín y López, con ilustraciones de Torcida.

Nos vamos a detener, sin embargo, en la colección de Bruño Cuentos de colores, especialmente en la serie Los Malos. ${ }^{18}$ Dos álbumes nos han lla-

18 La colección de la que estamos hablando continúa su singladura, puesto que se acaba de publicar El ogro Comeniños de Lalana y Monreal (Madrid, Bruño, 2000). 
mado la atención, El lobo feroz y Pelotieso y Ricitos de Oro, ambas de Monreal y Lalana (1999). En ellos se produce una simbiosis entre texto e ilustración digna de comentario. Tanto en un álbum como en el otro, el texto ha sido construido tomando como hipotexto dos cuentos tradicionales muy conocidos por los destinatarios infantiles. En el primer caso, se trata de Los tres cerditos y, en el segundo, de Los tres ositos y Ricitos de Oro. El narrador opta por ofrecer lo que ocurrió antes de llegar a las historias ya conocidas: cuándo y cómo nació la enemistad entre el lobo feroz y los tres cerditos y por qué Ricitos de Oro acabó en casa de los tres ositos. Las dos historias están presididas por el humor y la desmitificación como procedimiento constructor, en la línea de lo que Lalana suele ofrecer en obras puramente infantiles. ${ }^{19}$ Las llamadas directas al receptor son habituales y, sobre todo, los anacronismos. En este sentido, las ilustraciones de Monreal se imbrican en la línea del texto y ofrecen una visión del mundo con ojos de niño. Los dibujos son planos y llenos de colorido, como muy bien declara Escarpit (1996: 17), y se combinan en la técnica del collage con fotografías reales ya sea de objetos como de paisajes, todo ello de clara influencia cubista. De esta forma, el texto y la ilustración cabalgan conjuntamente entre la realidad y la fantasía, entre la actualidad y el «hace muuuuchos años». La imagen rompe la linealidad del texto constantemente presentando un mundo ambiguo y fronterizo.

El mercado presenta en los últimos años gran cantidad de libros basados en esta técnica que resulta muy atractiva para los primeros lectores. En lo que concierne al formato, estos libros son fieles a lo que hemos señalado como habitual en los álbumes: ediciones cuidadas, cubiertas y contracubiertas de cartón duro, papel satinado en la constitución de las páginas y, eso sí, en todos ellos coincide la letra cursiva que se asemeja al tipo de letra con el que el niño comienza a leer y escribir.

Por otra parte, aparecen en el mercado libros que se basan en imágenes pero que superan los límites de la ilustración para caminar hacia lo que se suele denominar como libros interactivos (cf. Colomer, 1999: 144). Se alude con esta etiqueta a una clase de obras que invadió las librerías en los años ochenta y que se basaba en el concepto de lector activo hasta sus últimas consecuencias. Este tipo de libro interactivo, descendiente directo de

19 Cf. Tejerina, 1993: 54; Tabernero, 1995: 801-806. 
los pop-up, que suele encontrarse a medio camino entre el libro y el juguete, cuenta en su composición con un entramado de lengüetas (Elmer, de Mckee), tiras combinables (Teo se disfraza, de Denou), elementos desplegables (La casa de Maisy, de Cousins), agujeros (Juega al escondite con el cerdito Wibbly, de Inkpen), ventanas e incluso objetos añadidos relacionados con la historia que se cuenta. Uno de los ejemplos más afortunados en esta línea de edición es, sin lugar a dudas, El cartero simpático en Navidad, de los hermanos Ahlberg.

Los libros de estas características juegan con las tres dimensiones, en algunos casos, y se centran en la participación del lector desde la perspectiva de la manipulación. La historia, el texto, por consiguiente, pierde fuerza en detrimento del aspecto plástico, de tal modo que es habitual en este tipo de obras encontrar sucesiones de cuadros o escenas independientes entre sí, como ocurre, por ejemplo, en Bromas de animales, de Faulkner y Spender, compuesto por una serie de preguntas que se resuelven con respuestas chistosas.

Las posibilidades materiales con las que en la actualidad cuentan los editores han propiciado que este tipo de libros haya superado las barreras de la recepción infantil y se dirija a toda clase de público basándose en el aspecto material de la edición y confluyendo con el concepto de libroregalo o libro-juego para todas las edades. No extraña, por lo tanto, leer en las contracubiertas comentarios como el que viene a continuación:

\footnotetext{
Inspirado en el cuento clásico de Robinson Crusoe, Robinson Ratón es un libro atractivamente ilustrado con una original cubierta de figuras de cartulina móviles. Puede guardarse en una biblioteca o colgarse en la pared como si fuera una escultura de papel. Un libro delicioso, que tanto pueden apreciar los niños como los adultos (Moseley y Craig (1998), Robinson Ratón, Barcelona, Destino).
}

Así Kalandraka ha publicado estuches de álbumes reducidos bajo el título de Minilibros para soñar (2002) (figs. 28 y 29). En la línea de libros concebidos para niños y para adultos - no olvidemos que es el adulto el que desempeña las funciones de mediador - contemplamos la aparición de nuevos materiales como los acetatos y hologramas (Hadas malvadas, de Steer y Ludlow) que, prescindiendo del texto, constituyen un verdadero placer para la vista tanto de niños como de adultos. Una vez más la doble recepción propia del discurso literario infantil nos sale al encuentro. 


\subsubsection{El libro ilustrado}

En el libro ilustrado, como hemos mencionado más arriba, la relación de interdependencia entre imagen y texto es menor que la que se establece en el álbum. Se entiende, pues, que el autor de imágenes realiza una aportación artística personal, puesto que, tomando el texto como base, interpreta sus sugerencias, las amplía y enriquece, huyendo de la mera función ornamental (Wensel, 2000: 152). Aunque la imagen nazca del texto, el ilustrador realiza una creación artística con entidad propia. El formato de este tipo de obras suele presentar dimensiones más reducidas que las del álbum, sin llegar a las del libro de bolsillo. Las ediciones son también muy cuidadas, generalmente de tapa de cartón duro y papel satinado en el interior, aunque es de reseñar la aparición de ediciones en papel reciclado, sobre todo por iniciativa de la editorial Alfaguara. La disposición habitual suele ser la del texto en la parte izquierda y la ilustración a la derecha o bien texto e ilustración combinados tanto en la página derecha como en la izquierda. A diferencia del álbum aquí la imagen parte del texto con el fin no de repetir sino de ofrecer otra perspectiva desde un código diferente. Es la ilustración que se suele encontrar en los libros dirigidos a lectores de 6 años o más. El texto va adquiriendo una extensión mayor que en el álbum y se sigue manteniendo la letra cursiva en la mayoría de los casos.

La ilustración en este tipo de libro afianza el poder sugeridor del texto y contribuye a crear a los personajes dándoles vida y características propias tanto físicas como psicológicas. Ejemplo de lo que acabamos de afirmar constituye la serie Sapo y Sepo (fig. 30), de Lobel. Los personajes de los dos protagonistas vienen definidos por la ilustración. Se trata de dos sapos, uno de color marrón y otro de color verde, que son amigos inseparables. La imagen que se ofrece de ellos es tierna y sosegada como lo son las características psicológicas que se desprenden de las historias que desarrollan los diferentes textos. Las ilustraciones salpican el texto reflejando las principales acciones de los personajes así como el espacio en el que se mueven. De este modo, en el capítulo, que en realidad es un pequeño cuento, titulado «El jardín» de la obra Sapo y Sepo, inseparables, el narrador cuenta cómo Sepo siembra unas semillas con el propósito de crear un jardín igual al de su amigo Sapo y cómo se ocupa de que las semillas crezcan. Para ello, y pensando que no crecen porque tienen miedo a salir, Sepo les canta, les 
lee cuentos, les habla y al final, después de haber conseguido su objetivo, llega a la conclusión de que cuidar un jardín implica mucho trabajo. La ingenuidad del sapo aparece reflejada en su imagen detallada y bonachona, viviendo en común acuerdo con la naturaleza, en una suerte de locus amoenus matizado por una gama de colores en la que predominan los pardos. La parsimonia con la que los sapos realizan todas sus actividades aparece sugerida en el texto y preside la ilustración así como la ironía con la que se aborda cada una de las aventuras. El texto posee un encanto especial; de él se desprende un humor cálido que, en muchas ocasiones, roza el surrealismo en su propia simplicidad. La ilustración potencia estos valores hasta extremos insospechados, de tal modo que se ofrece al receptor una obra en la que los dos códigos, caminando por sendas diferentes, crean uno de los clásicos de la literatura infantil norteamericana.

Del mismo modo, Urberuaga ilustra los relatos de Nesquens en Diecisiete cuentos y dos pingüinos, contribuyendo y ampliando la línea humorística y "monterrosiana» característica del autor. Una de las iniciativas muy presentes en el mercado editorial es la vuelta a la narrativa clásica (Colomer, 2004), con interpretaciones nuevas que proceden de la imagen. Suelen ser además ediciones muy cuidadas, casi de coleccionistas, de obras clásicas como Alicia en el país de las maravillas (figs. 31 y 32), de Oxenbury, o Las mil y una noches (fig. 33), de Anaya, o La doncella guerrera (fig. 34), de la colección Larumbe chicos, ilustrada por Guirao.

El libro ilustrado presenta como receptor natural al niño de 6 a 8 años que va desarrollando paulatinamente su competencia literaria. Así obras como Por el hilo se saca el ovillo, de Kitamura, trabajando la estética del cómic, se acercan a este tipo de lector contando una historia detectivesca en un mundo de corderos al que el autor nos tiene ya acostumbrados. Por citar más ejemplos, sin ánimo de llegar a ser exhaustivos, podríamos aducir el de Te quiero, Valero, de Lalana y Ferrer, obra en la que se produce una perfecta simbiosis entre la actitud desmitificadora del narrador y la ilustración cubista de la leyenda de San Jorge, o el de La estupenda mamá de Roberta, de Wells, cuento en el que la imagen refuerza la atmósfera maravillosa de la narración verbal.

El hecho de que la ilustración parta del texto no implica que la misma quede relegada a un segundo plano sino que, como hemos mencionado, crea los personajes y les confiere unas características que el texto ni siquie- 
ra sugiere como ocurre en los casos de No nos podemos dormir, de Stevenson, o Historias de ratones, de Lobel, así como Matrioska, de Inkiow y Rius, o Quisicosas, de Mateos.

Mención aparte merece uno de los éxitos de los últimos tiempos en nuestro país como es el de Las tres mellizas, de Company y Capdevila, y la continuación de la serie en las Nuevas historias de la bruja aburrida, de Capdevila. Lluch (1998 y 2000) ha comentado el éxito de estos personajes infantiles que combinan la actualidad con los tiempos pasados en sus historias acompañadas por un dibujo muy simple de trazos fijos e individualizadores de cada personaje. El anacronismo como procedimiento surte efectos imprevisibles en el mercado del libro infantil.

Paulatinamente la imagen se va adentrando en el discurso narrativo que se aleja de la concepción del álbum y de los libros dirigidos, además, a lectores de edades tempranas. Así por ejemplo, una de las colecciones de Anaya dirigida a jóvenes y a receptores de edad indefinida ha optado por el formato de tapas duras y por la incoporación de la ilustración como elemento inexcusable en el discurso. Obras como Hasta (casi) cien bichos, de Nesquens y Arguilé, y Días de Reyes Magos, de Pascual y Serrano, avalan la calidad por la que ha optado esta línea editorial. Apuestas arriesgadas en la construcción de un receptor competente.

\subsubsection{6. ¿La ilustración puede definirse como paratexto?}

Después de lo que hemos expuesto, la definición que Genette (1989: 11) ofrece de la ilustración como paratexto con la relación de accesoriedad que ello implica no acaba de corresponder al papel que desempeña la ilustración en el discurso narrativo infantil de los últimos años. Es necesario, pues, plantear, al menos en lo que concierne al álbum y al libro ilustrado, la posibilidad de encontrar en la ilustración uno de los rasgos específicos del discurso narrativo infantil literario y de conferirle una denominación nueva que no la vincule a lo que Genette identificó como paratexto. La ilustración ha ido adquiriendo una presencia tal en el discurso literario infantil que constituye un elemento esencial en el proceso interpretativo. Texto e imagen, siendo códigos diferentes, contribuyen a crear el lector modelo que, en última instancia, funciona como estrategia generadora de significados. 
Las relaciones que se establecen entre texto e imagen en el discurso literario infantil no corresponden al enfoque paratextual. Ahora bien, todas estas consideraciones nos deben llevar a revisar varios aspectos, entre ellos el concepto de autor. ¿Quién es el autor de un álbum o de un libro ilustrado: el escritor o el ilustrador?

El libro ilustrado se debe a la producción creativa del que lo escribe y del que lo ilustra. Ambos son autores de idéntico rango, y los únicos dueños de su obra (Atxaga y Ferrer, El alfabeto que no llega a la i. Fig. 35).

Es necesario, por tanto, crear nuevos instrumentos de análisis que se adecuen a un discurso específico que se adentra en el camino de la experimentalidad a través de la conjunción de dos códigos diferentes que trabajan la doble recepción —adulto y niño-, otra de las características que puede diferenciar el discurso literario que nos ocupa.

Se trata de una nueva forma de contar acorde con una sociedad a la que corresponden nuevas formas de oralidad y en la que la polifonía es la nota dominante dentro de una posmodernidad que ha supuesto la creación de nuevos modelos culturales y literarios.

Cuando Alicia se preguntaba «¿De qué sirve un libro sin dibujos ni diálogos?», sin saberlo, estaba definiendo una de las claves del discurso infantil y juvenil del siglo XXI. Cuando la editorial de Saturnino Calleja incorporaba el nombre del ilustrador a la cubierta estaba reclamando con un siglo de antelación la presencia de la imagen en la creación del espacio poético, en la creación del mejor de los mundos posibles.

Fernández (2004b) en una de sus intervenciones en el Cervantes virtual de ilustración, habla de un siglo que pudo ser de oro, refiriéndose al XX; habla de este como un siglo de desconcierto y no carece de razón. Sin embargo, estamos en disposición de afirmar que si el siglo XX no llegó a ser de oro, el XXI puede llegar a conseguirlo.

\subsubsection{El peritexto editorial}

Genette (1987) distingue dentro del paratexto la presencia del peritexto editorial que se identificaría con el paratexto exterior, es decir, lo que concierne al formato, la cubierta, la página del título y los anexos, o lo que es lo mismo: todo aquello que se encuentra bajo la responsabilidad del edi- 
tor. La colección se establece como una de las características editoriales que es necesario analizar (Lluch, 1998: 79-80).

La colección se define como un macropararatexto que integra obras con rasgos comunes. En la literatura para adultos las colecciones suelen estar organizadas por géneros, épocas o temas. En la literatura infantil el sentido de aquellas es otro: indicar la edad del lector al que las obras van dirigidas. El editor tiene en cuenta, por otra parte, que cuanto más amplio sea el grupo al que va dirigida la colección, mayor es el número de hipotéticos compradores. De este modo, en los últimos años (cf. Fernández, 2000b: 9-10), cada vez nos encontramos con más colecciones dirigidas a los más pequeños. Las narraciones infantiles que se publican en la actualidad suelen insertarse en las colecciones de las diferentes editoriales. Resulta muy extraña la publicación de libros aislados que no sean álbumes de grandes dimensiones o libros-juego.

Lluch (1998: 81-86) detalla cuáles son las informaciones que se vierten en el peritexto editorial de las colecciones de narraciones infantiles: la edad del lector, el formato, la cubierta, la ilustración de la cubierta, el nombre de la colección, el anagrama, las series y la tipografía. Cada uno de los rasgos señalados son cuidados y presentados homogéneamente en los títulos de las diferentes colecciones, lo cual, tal como indica Lluch, presenta bastantes puntos de encuentro con lo que Couégnas (1992) ha definido como "paraliteratura». Dependiendo de la edad del lector, cada uno de los elementos reseñados adquirirá una u otra forma. Lo que aquí nos interesa es analizar, dentro del paratexto mencionado, cuáles son los receptores de las informaciones que en él aparecen. A ello vamos a dedicar las siguientes líneas.

Una de las características que distingue la literatura de adultos de la infantil es la duplicidad de la recepción, o lo que es lo mismo, la existencia de un doble receptor: el adulto que recomienda la lectura y el niño. En el paratexto editorial se refleja la duplicidad de recepción de la que hemos hablado.

\subsubsection{La edad del lector}

La edad del lector es uno de los elementos más destacados en las colecciones. Una de las editoriales pioneras en dividir sus colecciones a partir de la edad a la que las obras iban dirigidas fue SM. Sin duda, esta 
información que condiciona los demás elementos paratextuales de la colección no está dirigida al receptor infantil sino al adulto - padre o maestro- que recomienda la lectura. El editor y el director de la colección saben que los adultos buscan las lecturas recomendadas para los niños a los que intentan educar.

En unas ocasiones, las recomendaciones son acertadas; en otras, simplemente, se trata de un criterio de ampliación de mercado. Así, no son aislados casos de narraciones recomendadas para niños a partir de 3 años que corresponden a receptores con una mayor competencia literaria. Compruébese, por citar un ejemplo, cómo la colección titulada Cuentos de colore, serie Los Malos, de editorial SM, ha sido dirigida, y de esta manera reza la contraportada, a lectores a partir de 3 años. Por el contenido de los textos y de las ilustraciones, la competencia literaria de un niño de tres años no está preparada para acceder a obras como las que componen la colección. Es necesario que el lector haya asentado el acervo de los cuentos tradicionales para acercarse a obras que se basan en él, tomándolo como hipotexto. Sólo de esta forma se producirá el efecto de extrañamiento del receptor que persigue la historia. En este sentido, los directores de las colecciones son los responsables más directos de este tipo de incongruencias. Si bien es verdad que a menor edad recomendada, mayor posibilidad de mercado.

\subsubsection{La cubierta y la contracubierta}

La cubierta y la contracubierta acumulan la mayor cantidad de información. En la cubierta aparecen el nombre del autor, el título del libro, el nombre del ilustrador, el título de la colección y el de la serie, además del anagrama que caracteriza la colección. Algunas colecciones establecen colores que distinguen las edades a las que las obras se dirigen, tal es el caso de Barco de Vapor: blanco para los primeros lectores; azul a partir de 7 años; anaranjado a partir de 9 años y rojo para la narración juvenil. Todos los componentes plásticos persiguen como finalidad última que el receptor, tanto el niño como el adulto, identifiquen a simple vista la edad del receptor al que la colección va dirigida.

La contracubierta suele presentar un acercamiento al contenido del libro y algunas noticias sobre la trayectoria literaria del autor. Correspon- 
de este paratexto a lo que Genette (1987: 98-109) denomina le prière d'insérer. El receptor de las informaciones allí contenidas es el adulto. Hay que diferenciar entre los libros dedicados a los más pequeños, en los que la contracubierta, sin ambages, se dirige explícitamente al adulto y a su responsabilidad educativa, y los dirigidos a lectores a partir de 6 años, que son menos explícitos en los mensajes didácticos. Así por ejemplo, en la colección El búho Renato de la editorial SM encontramos la siguiente información en la contracubierta:

Colección «EL BÚHO RENATO». Libros para el desarrollo de la atención. A medida que el niño lea la historia, ésta le incitará a buscar personajes o cosas. Un divertido juego de lectura que encadenará a grandes y pequeños (Alcántara y Gusti, 1999, El búho Renato en el zoo, Madrid, SM).

Como se podrá comprobar, el mensaje está dirigido explícitamente al adulto que va a adquirir el libro. Destacable es también el comentario acerca del posible receptor — grandes y pequeños—, puesto que el mercado que se sugiere es amplísimo y discutible.

Otro texto de contracubierta digno de análisis, esta vez de la colección Barco de Vapor, es el que sigue:

La historia de Ernesto es la historia de una adopción. Ernesto, a pesar de su corta edad — seis años-, sabe que sus padres verdaderos no hubiesen podido cuidarle. Y también sabe que puede estar muy seguro del cariño de sus padres adoptivos.

La escritora catalana MERCÈ COMPANY ha publicado numerosos libros infantiles. Algunos de ellos han sido traducidos al japonés, alemán, francés, finlandés, italiano e inglés. Entre otros posee los premios Ciudat de Olot 1982, Crítica Serra D’Or 1983 y 1985 y el Enric Valor, de narrativa infantil del País Valenciano, 1983.

Este libro acaba de obtener el PREMIO DE LITERATURA INFANTIL DE LA GENERALITAT DE CATALUNAA 1985.

Ediciones SM también ha publicado de esta autora Nana Bunilda come pesadillas, en la colección Cuentos de la Torre y la Estrella.

Primeros lectores. Segundo nivel.

Una vez más inferimos del contenido del texto la presencia de un lector adulto que juzgará el tema, si se adapta o no a sus necesidades, y el prestigio de la autora, además del nivel de lectura que el editor exige en la recepción. 


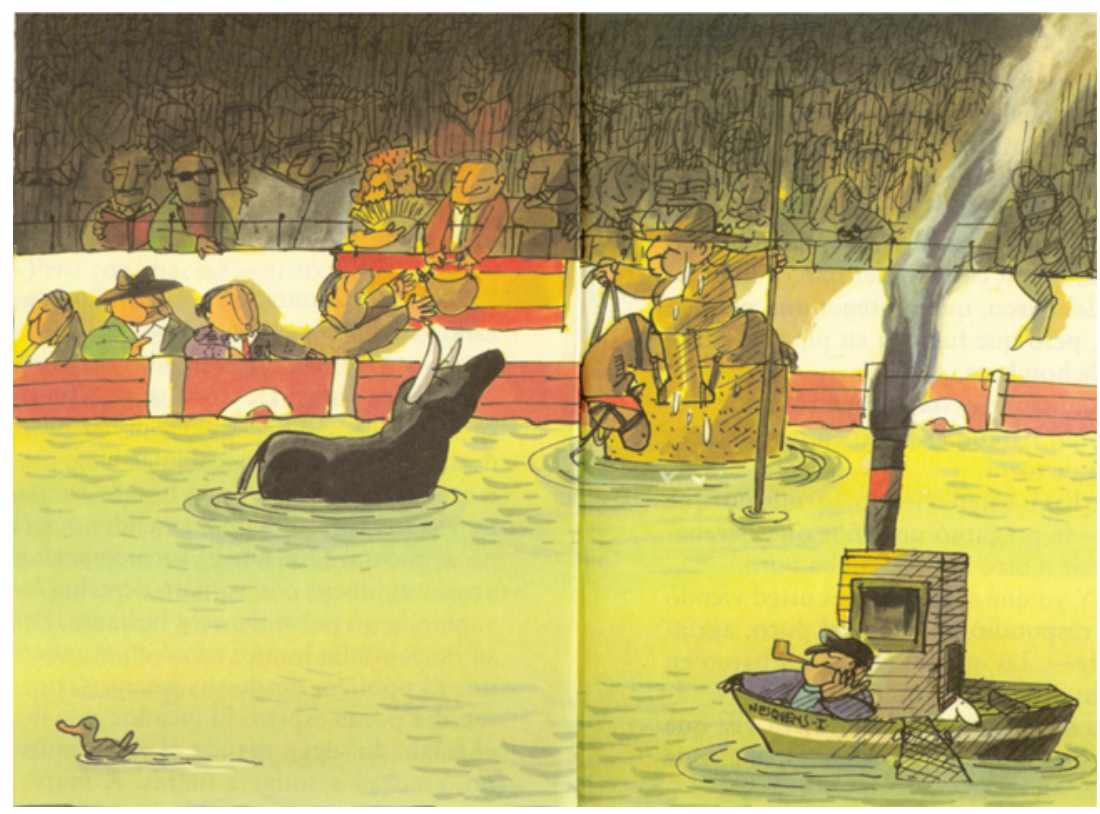

Fig. 1. Diecisiete cuentos y dos pingüinos.

Fig. 2. El grito de la grulla.

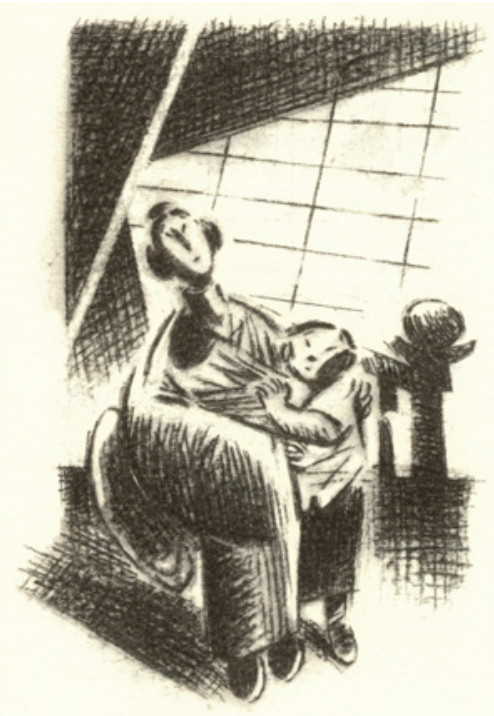




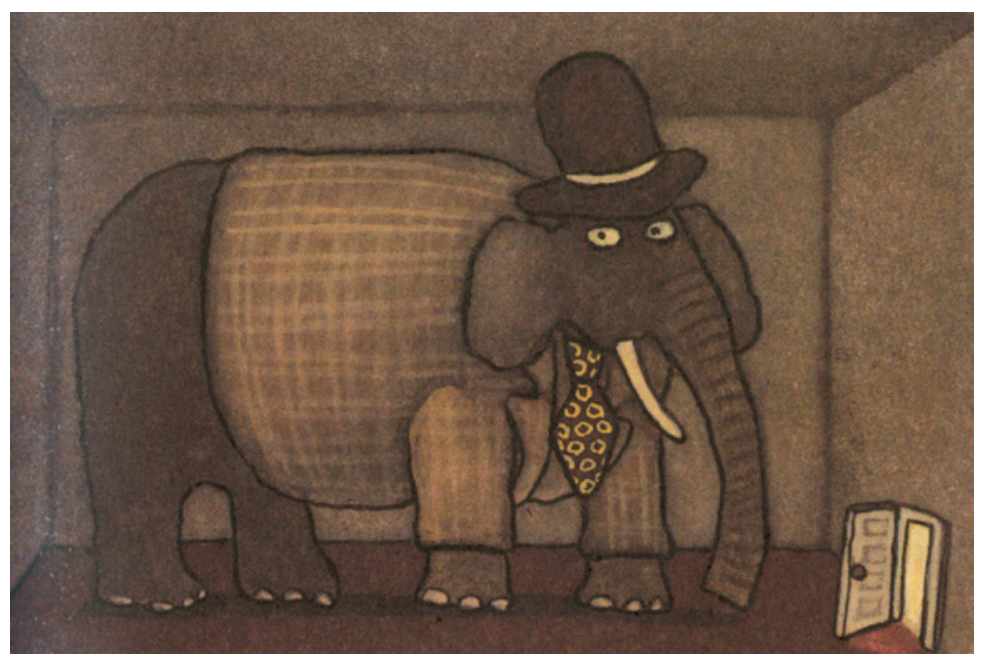

Fig. 3. Hasta (casi) cien bichos.
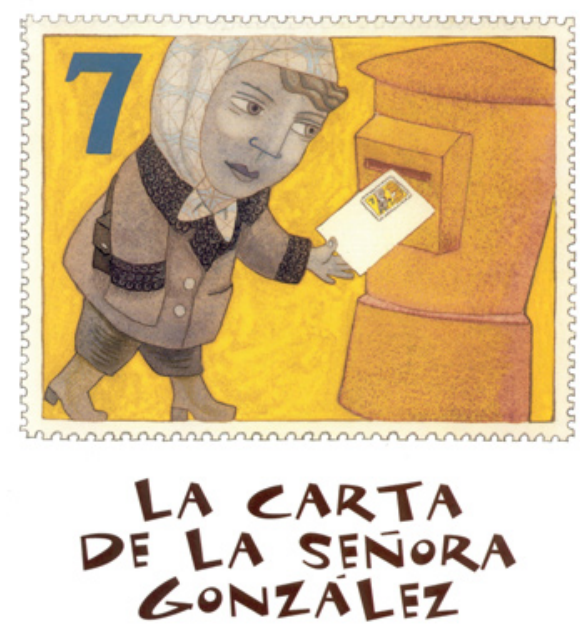

TEXTo dE SER GiO LAiRLA
iLustración dE ANA C. LARTite

Los ssictuess of

A la orilla del viento

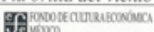

Fig. 4. La carta de la señora González. 


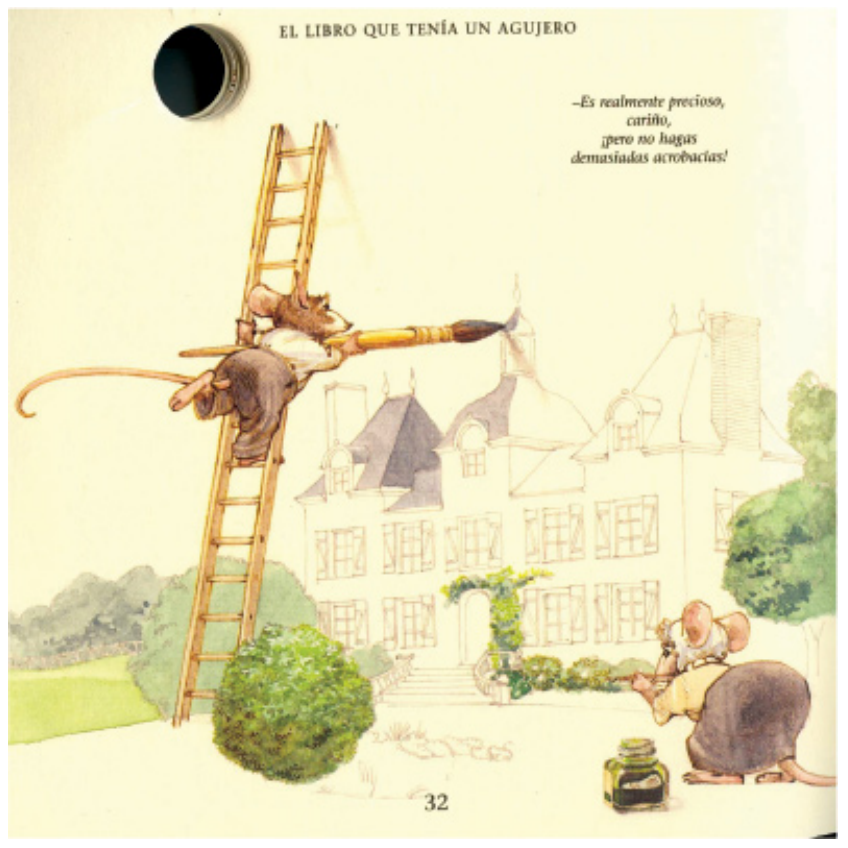

Fig. 5. El libro que tenía un agujero.

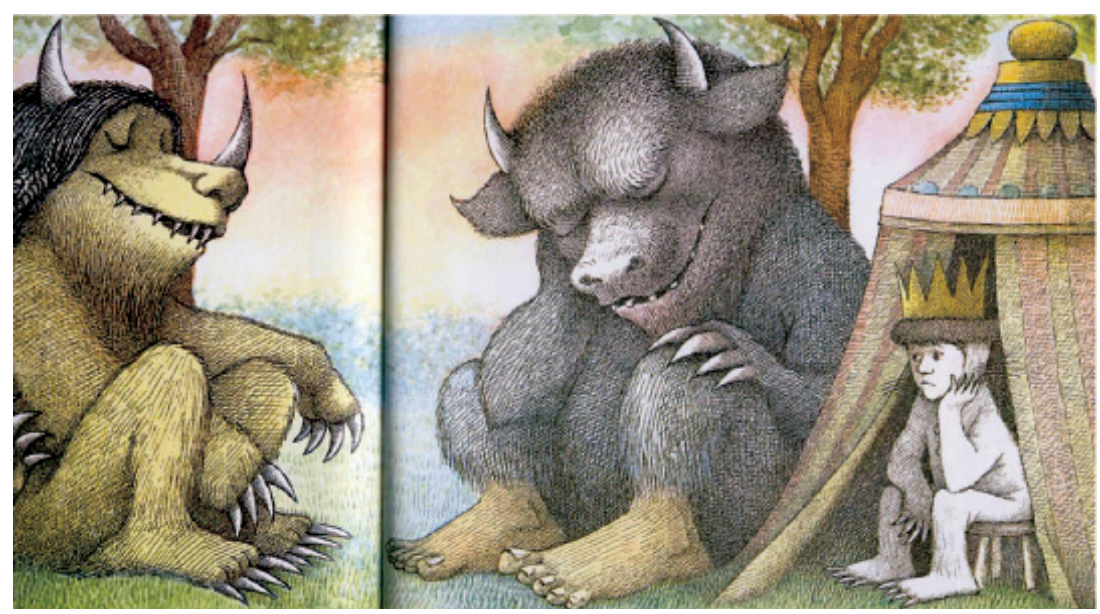

Fig. 6. Donde viven los monstruos. 
100 Otras formas de contar: los paratextos en el discurso narrativo infantil

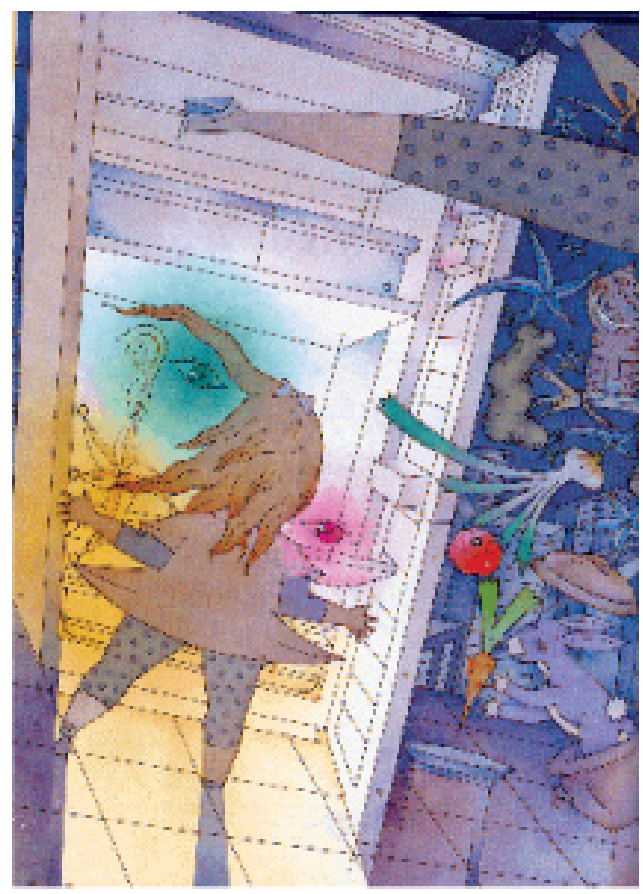

Fig. 7. Libro de las M'Alicias.

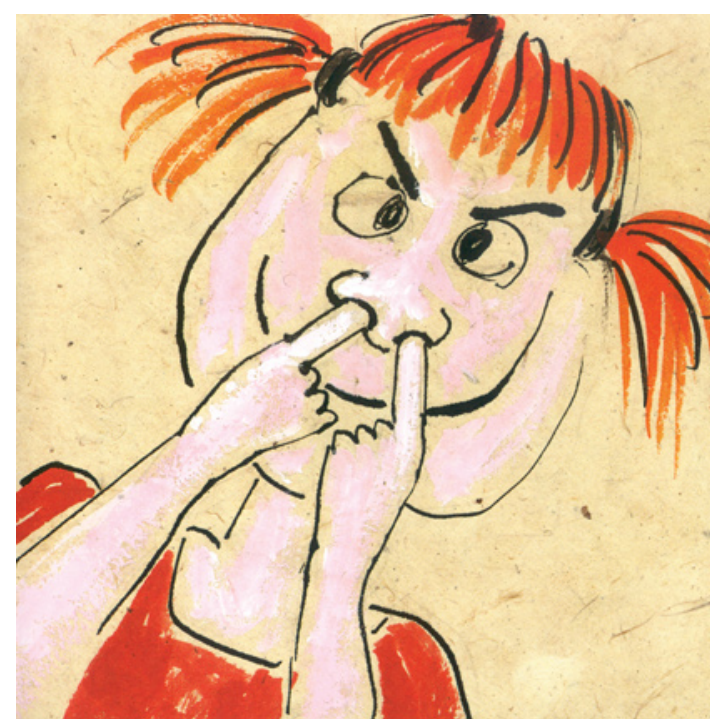

Fig. 8. Mamá fue pequeña antes de ser mayor. 


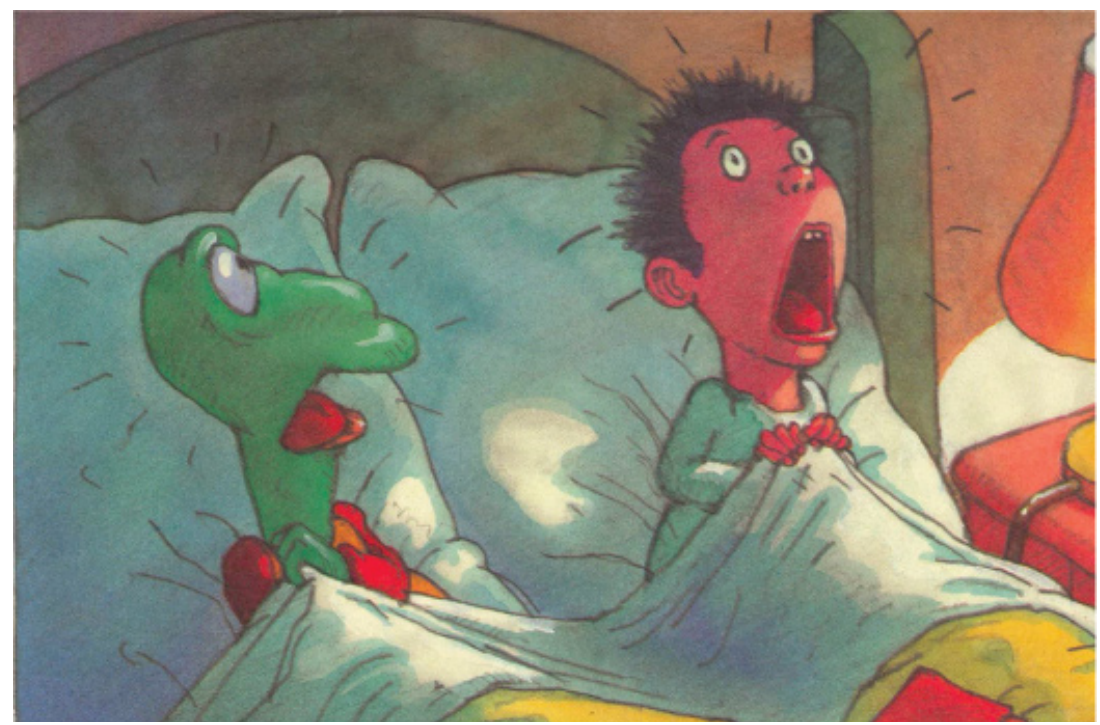

Fig. 9. Papá

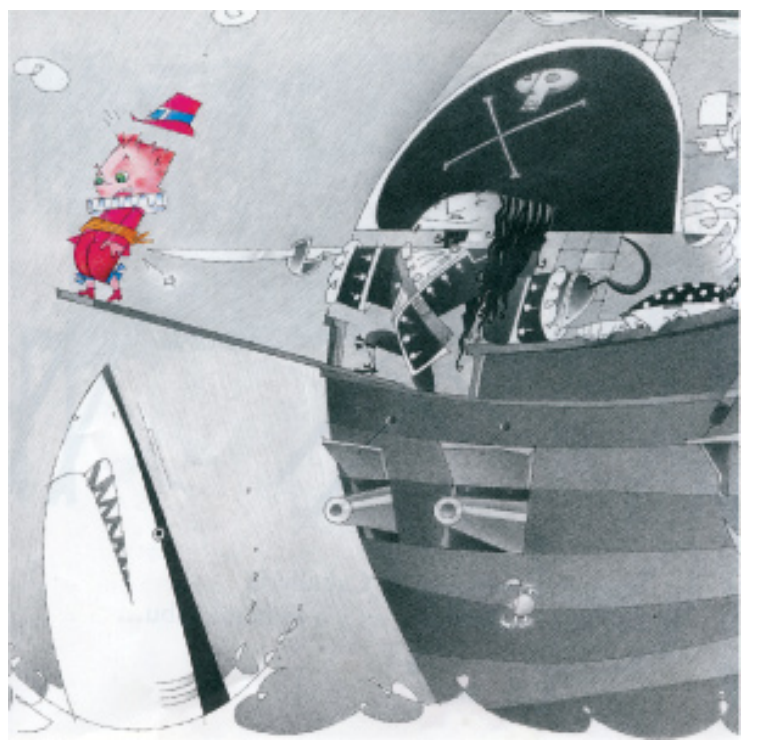

Fig. 10. iiiPapááá...!!! 
102 Otras formas de contar: los paratextos en el discurso narrativo infantil

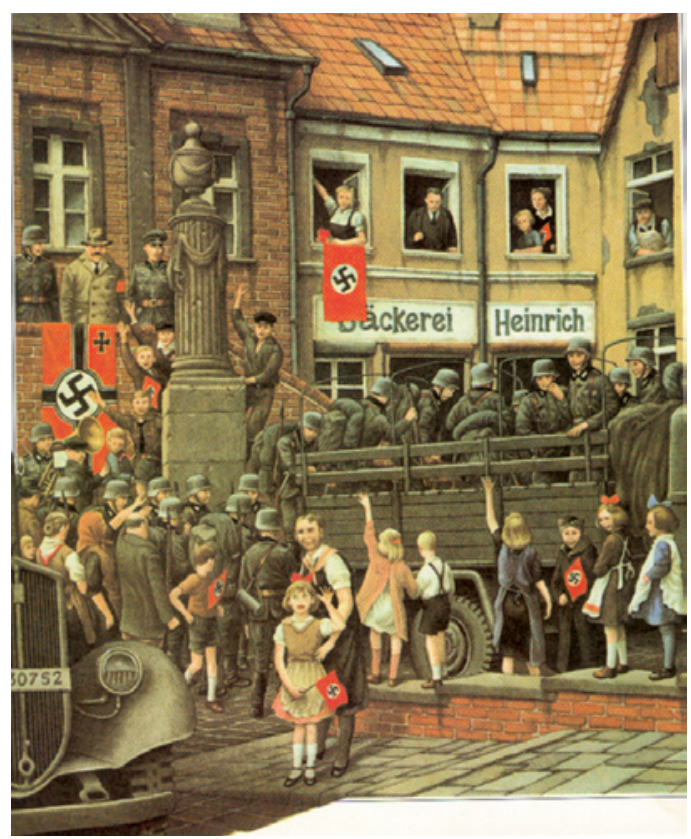

Fig. 11. Rosablanca

Fig. 12. Rosablanca.

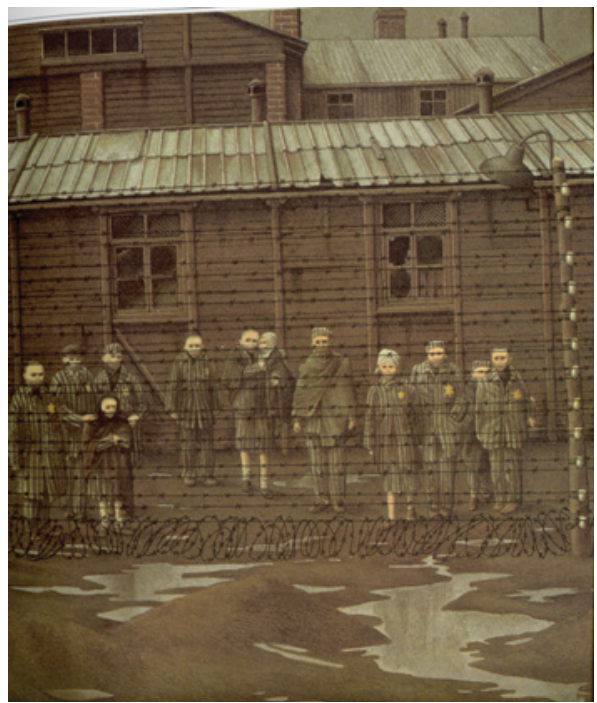




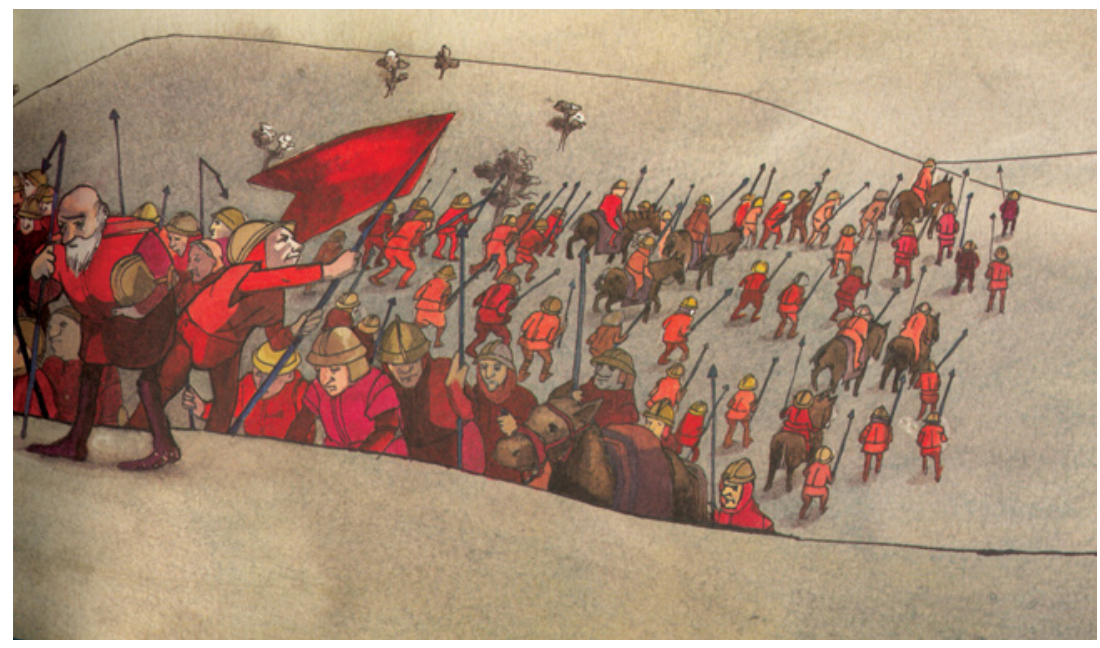

Fig. 13. De cómo Fabián acabó con la guerra.

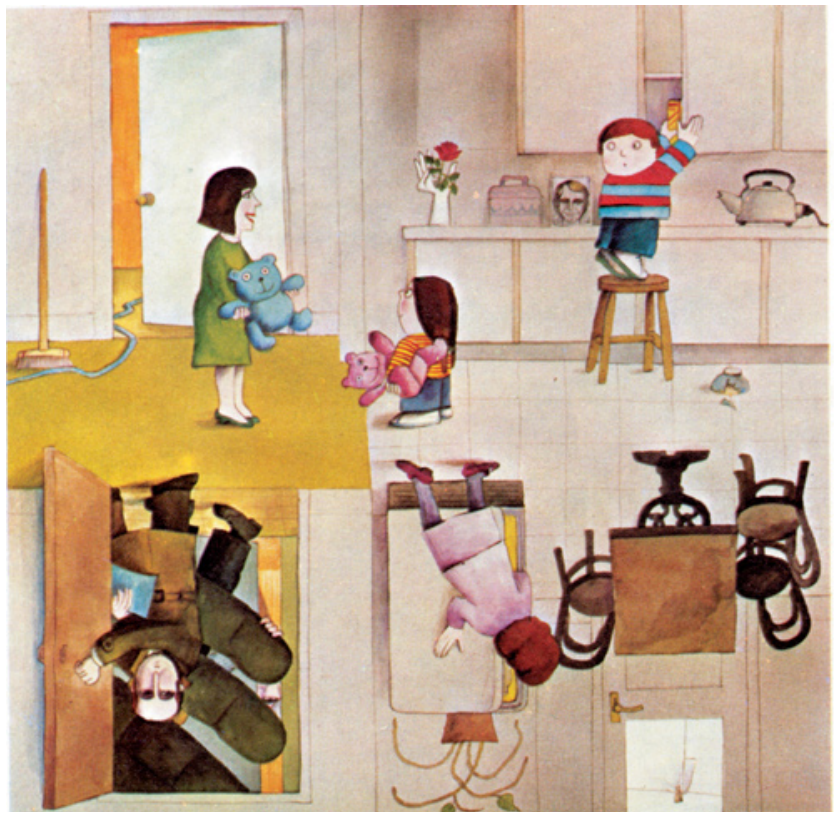

Fig. 14. Osito 


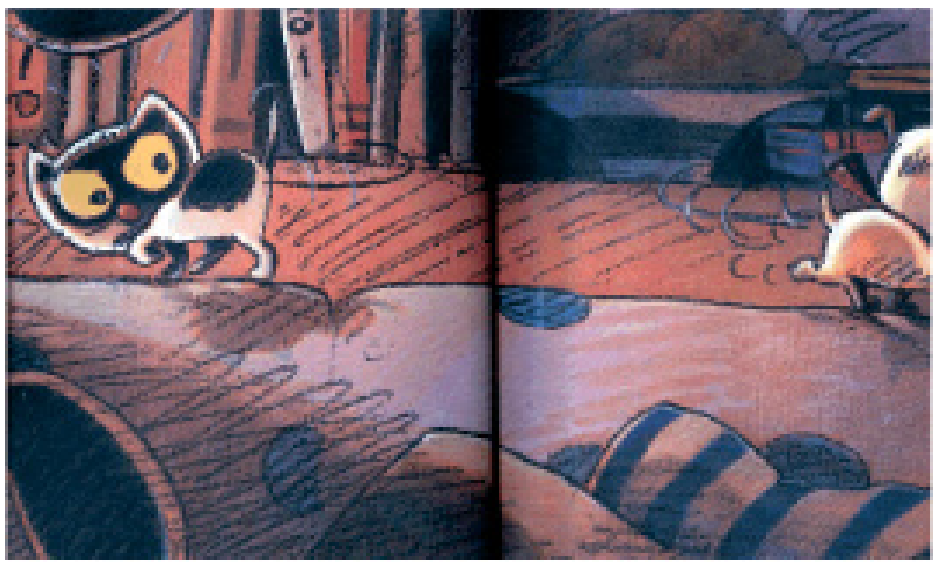

Fig. 15. Perro y gato.

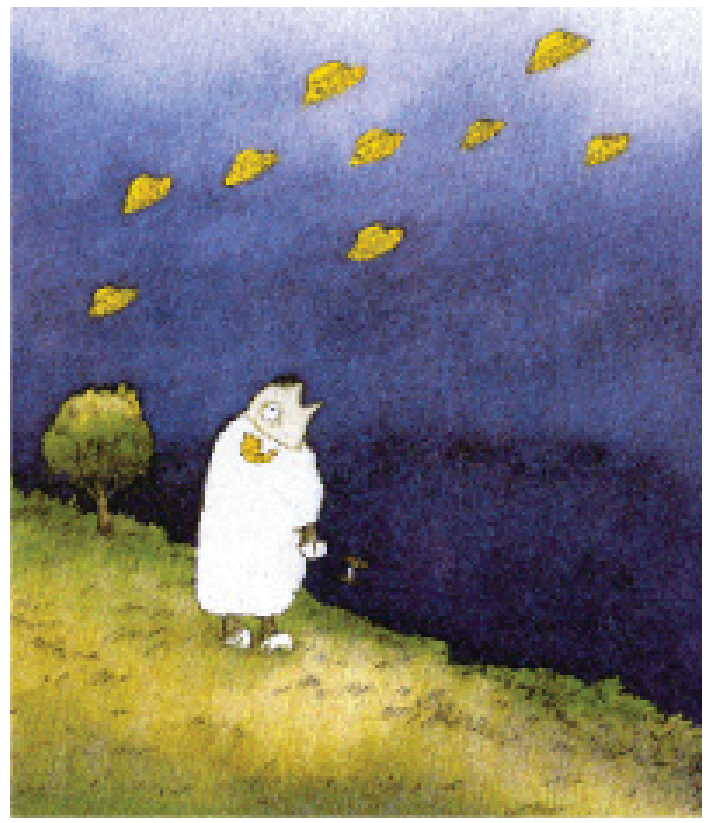

Fig. 16. Cuando los borregos no pueden dormir. 
Fig. 17. ¡Adiós, pequeño!
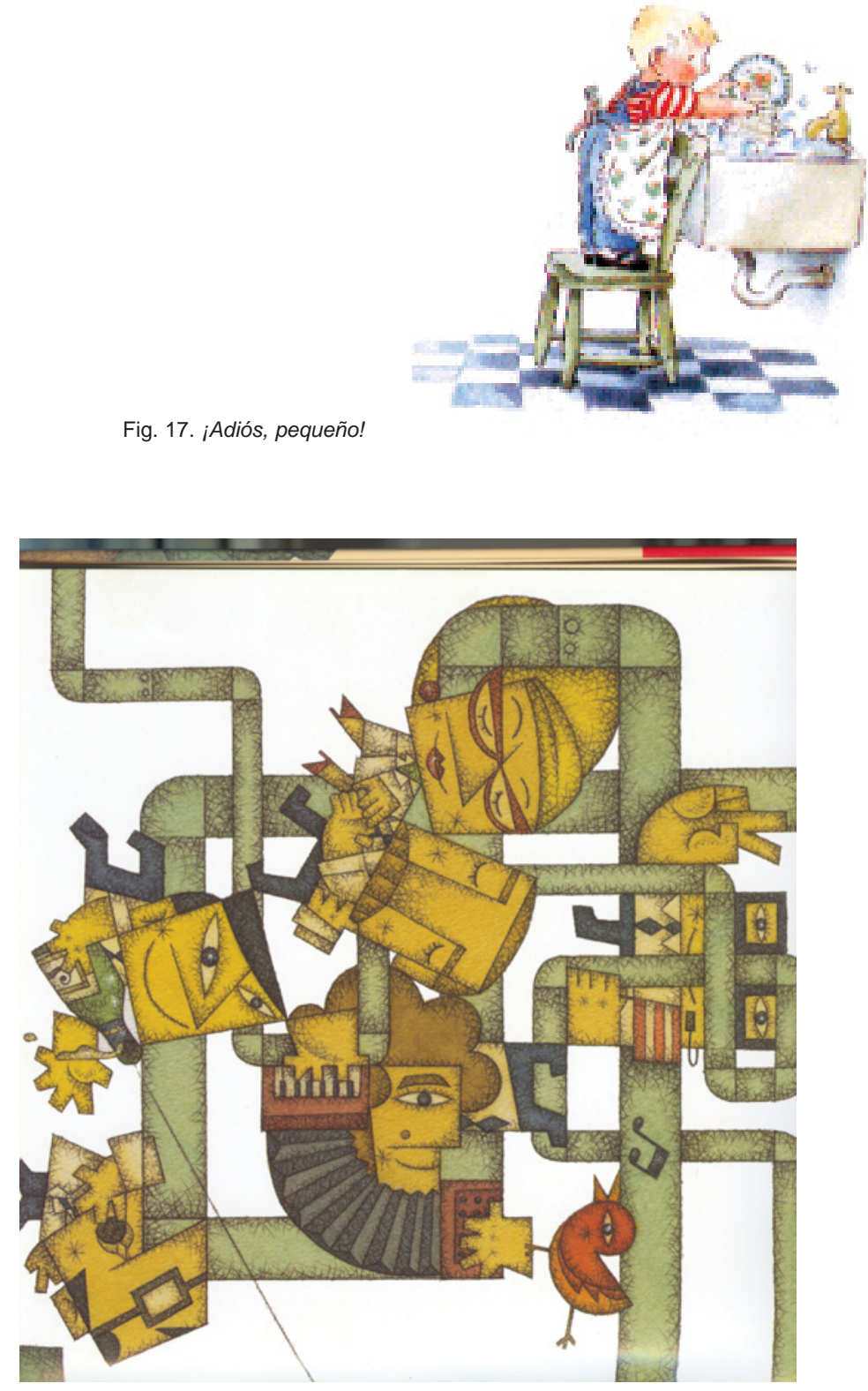

Fig. 18. Operación J. 


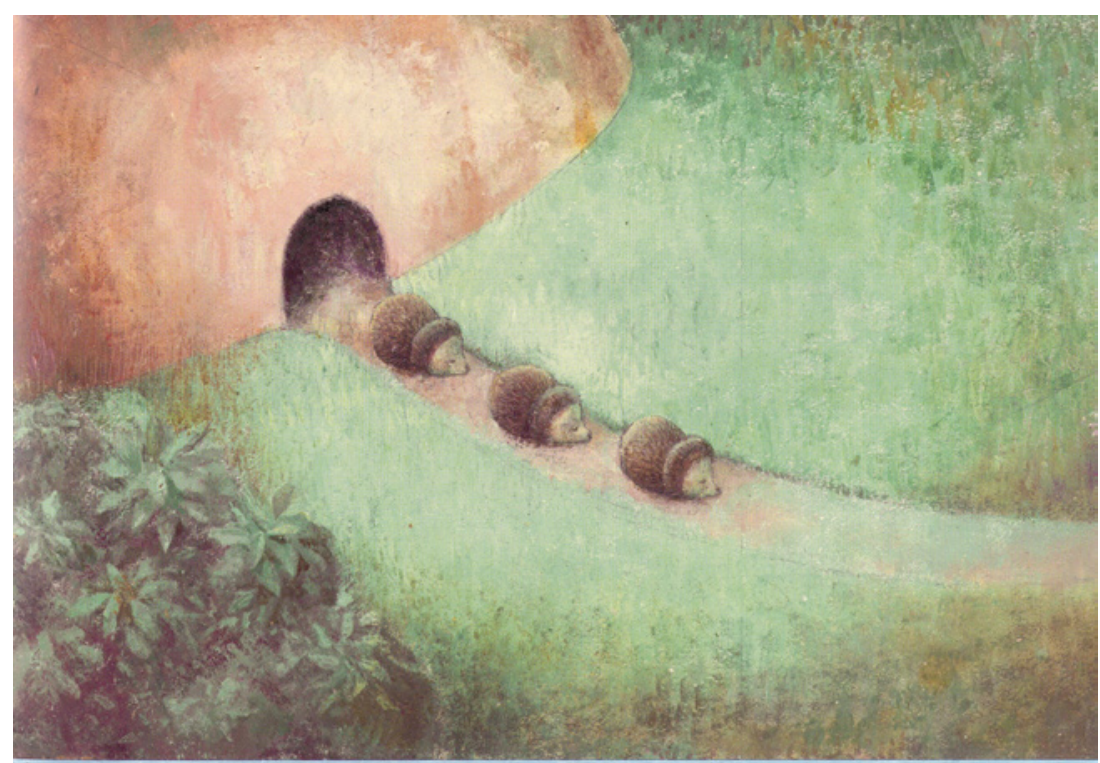

Unos erizos salen de su casa

de buena mañana. Buscan qué comer.

Fig. 19. Los tres erizos.

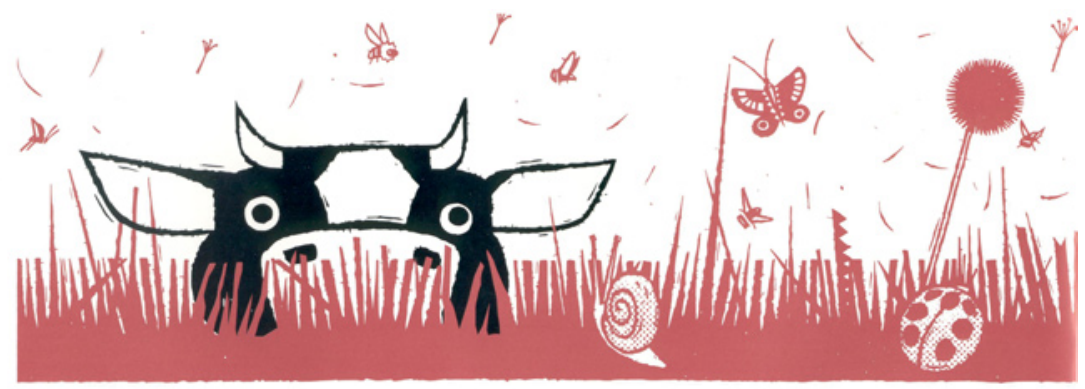

Sin embargo, existen vacas que lo que más les gusta es mirar.

Fig. 20. No todas las vacas son iguales. 
A Salomé.

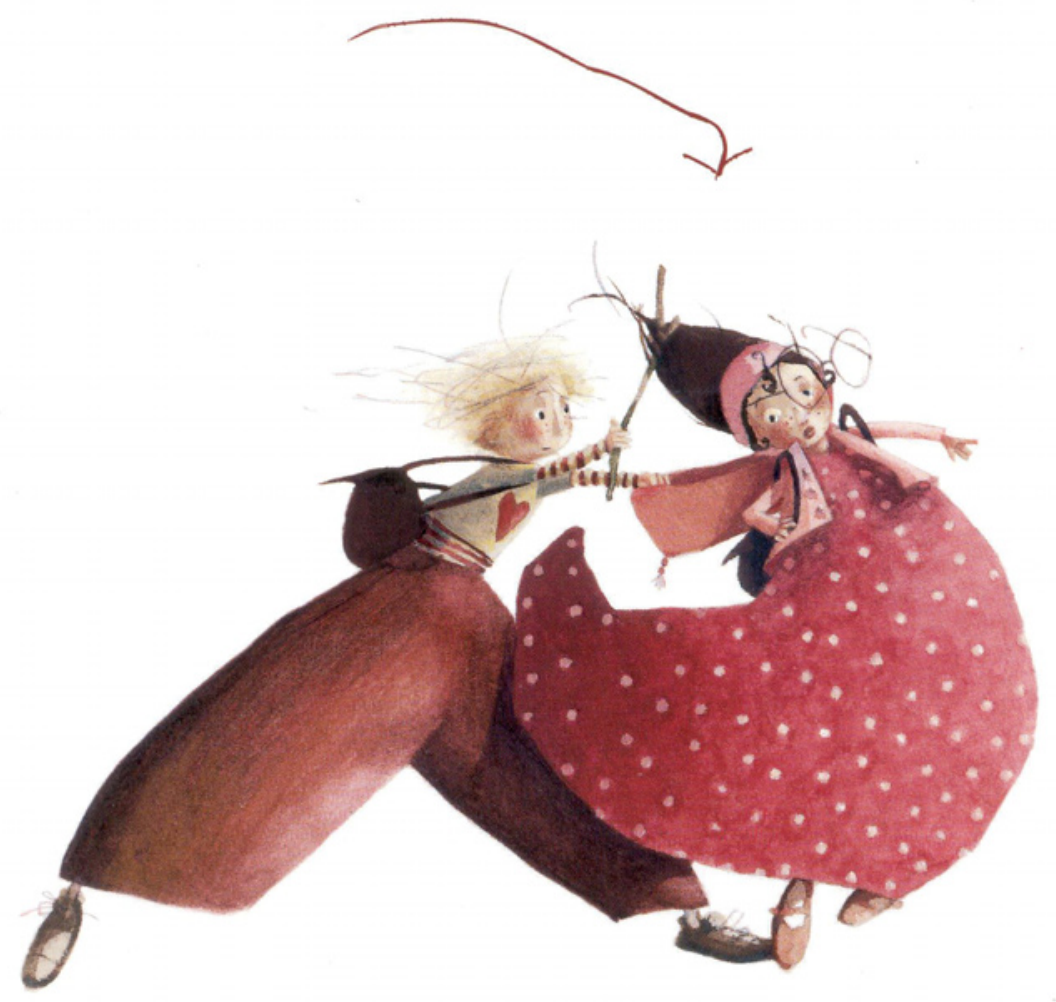

Fig. 21. Enamorados. 


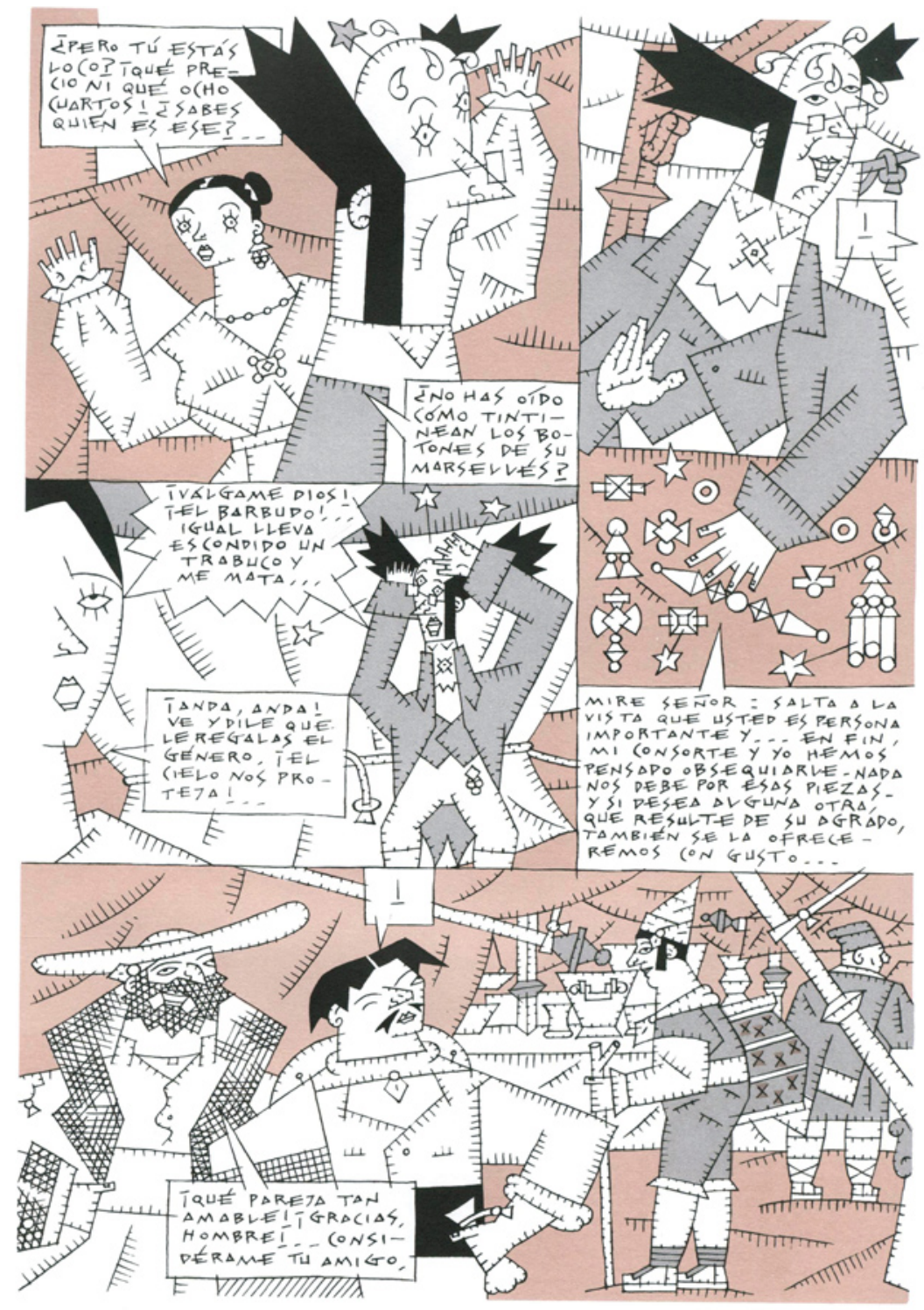

Fig. 22. Pie frito 


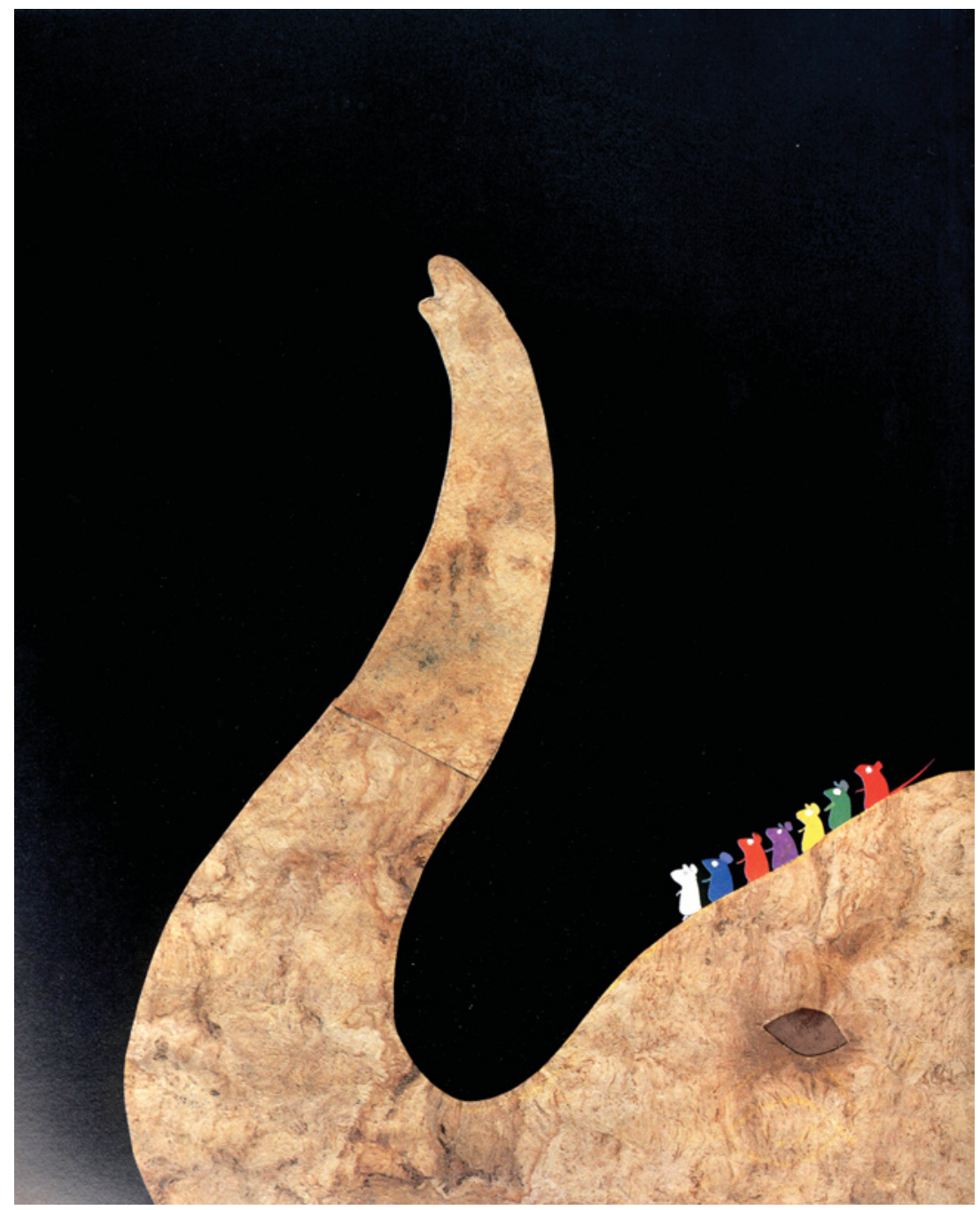

Fig. 23. Siete ratones ciegos. 
110 Otras formas de contar: los paratextos en el discurso narrativo infantil

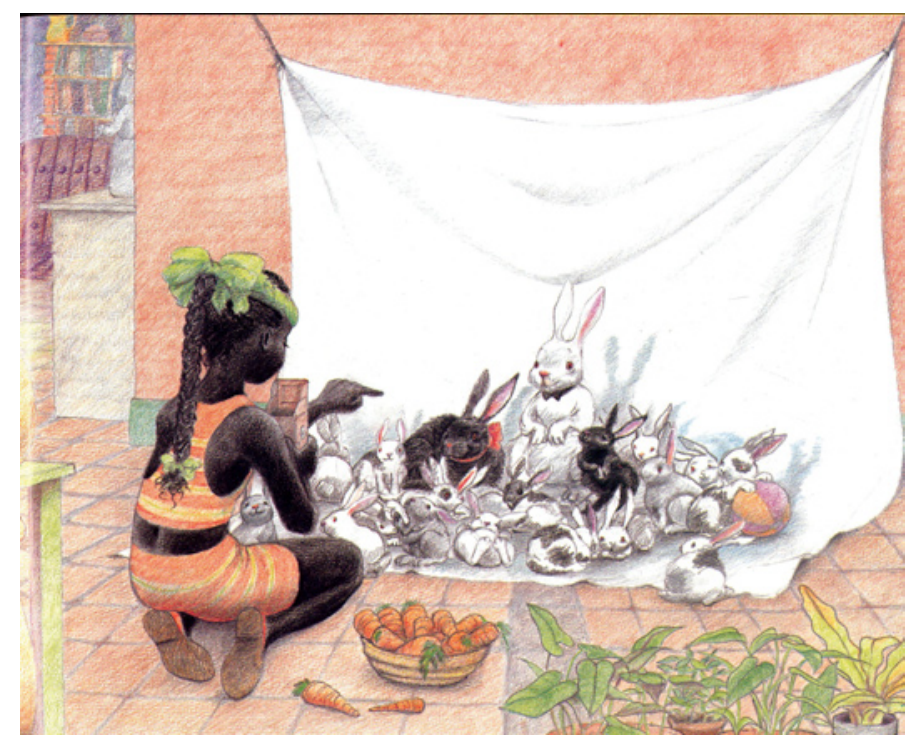

Fig. 24. Niña Bonita

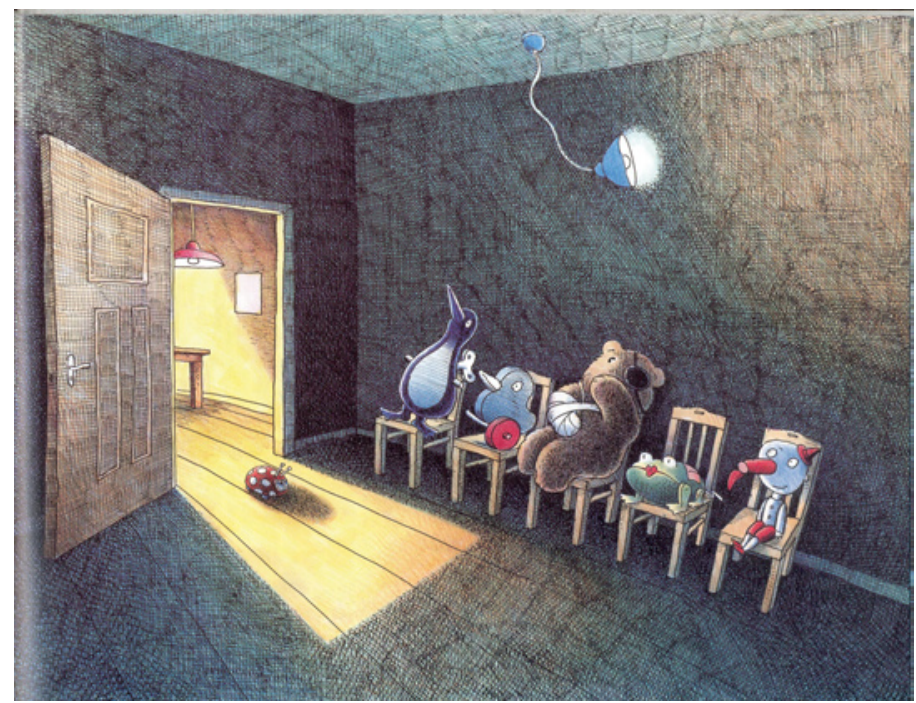

Fig. 25. Ser quinto. 


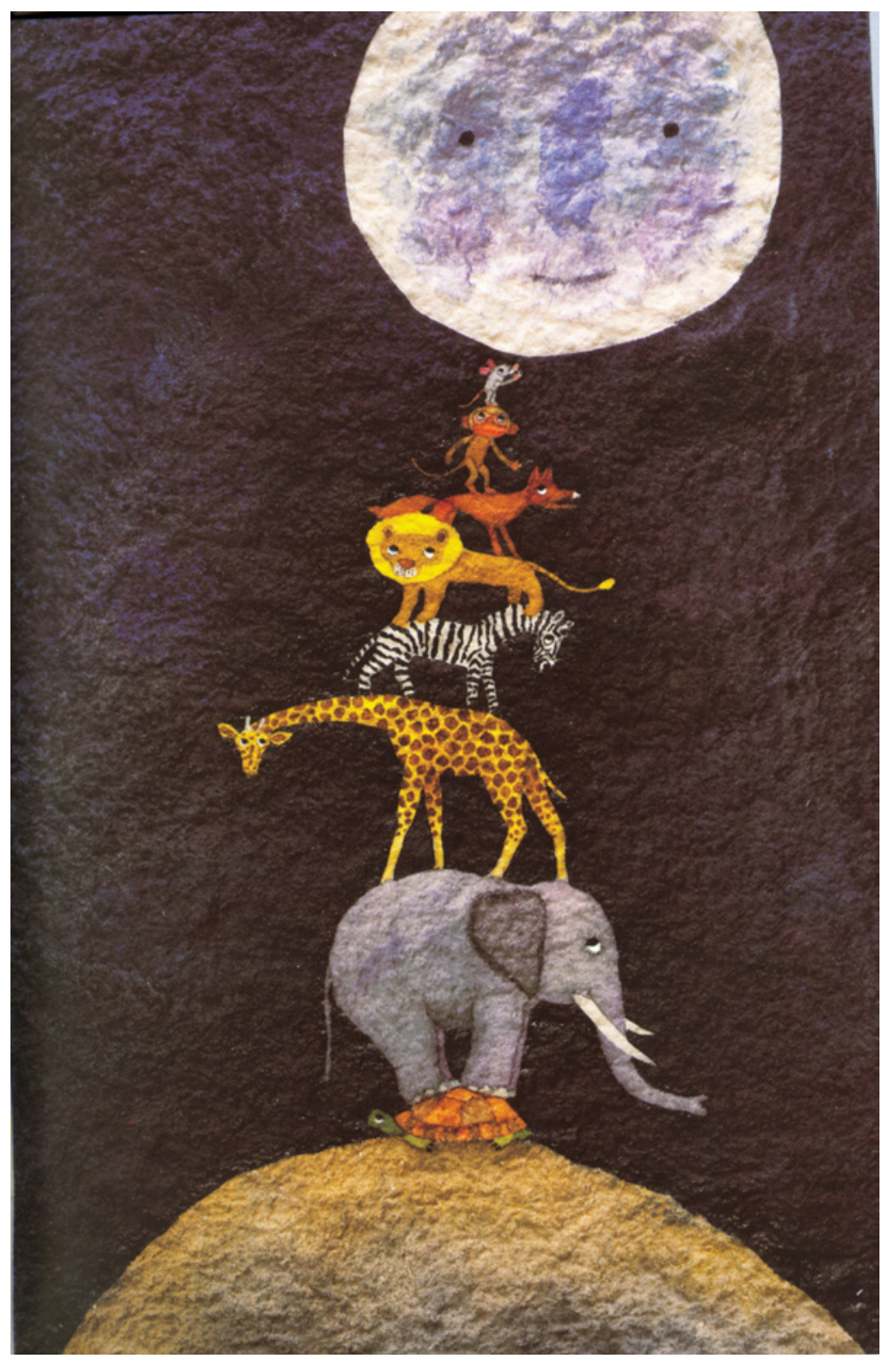

Fig. 26. A qué sabe la luna. 
112 Otras formas de contar: los paratextos en el discurso narrativo infantil

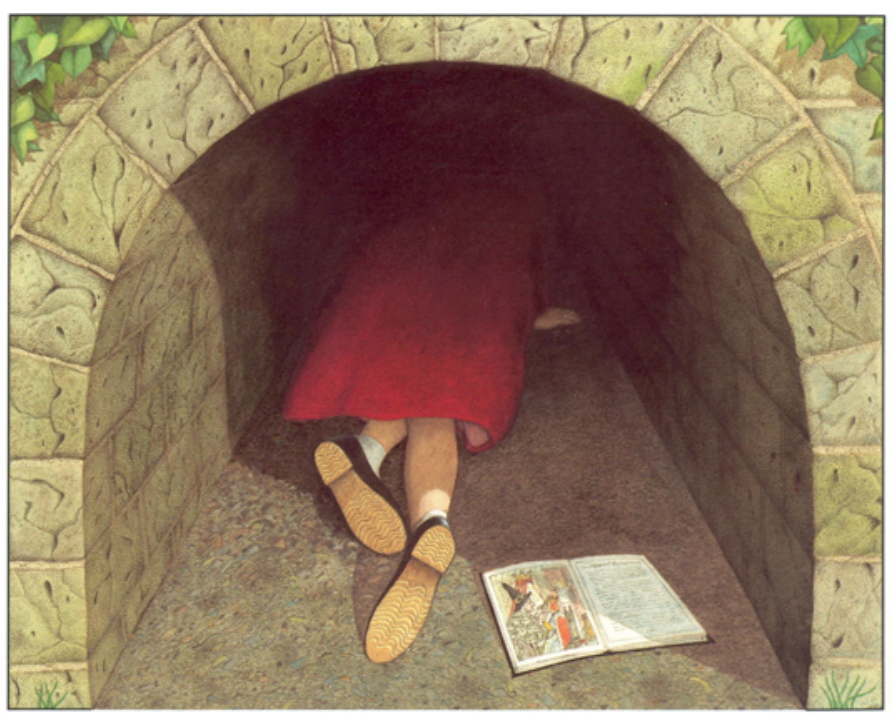

Fig. 27. El túnel.

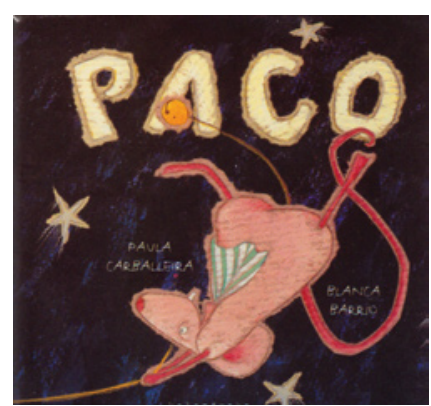

Fig. 28. Paco.

Fig. 29. Los dos jorobados.

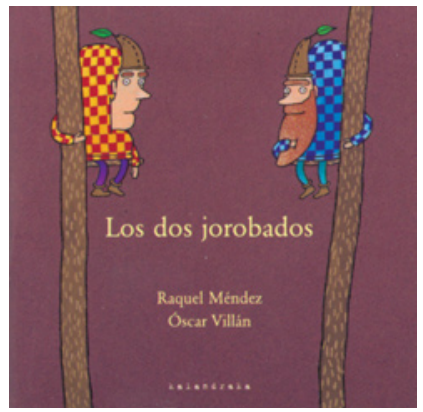


Duranie todo el dia siguiente Sepo les cantio canciones

a sus semillas.

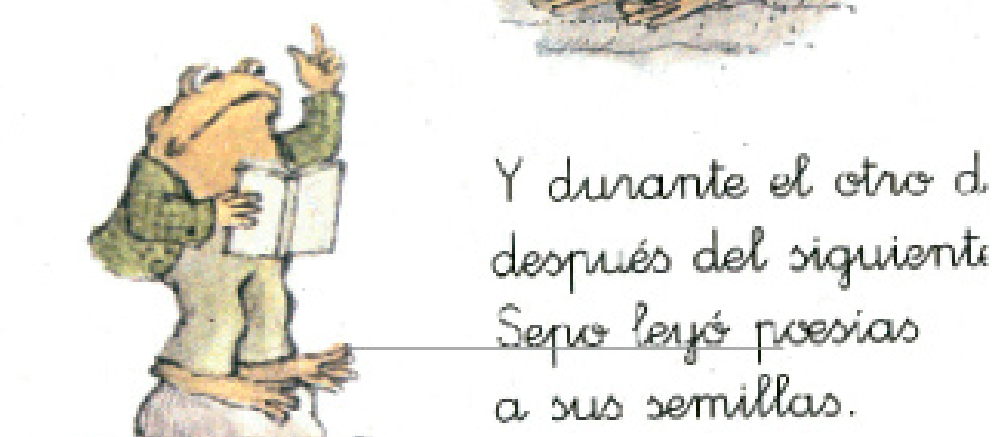

$Y$ dirante el dia que siguió al otro después del siguiente. Sepo estuvo tocando misica para sus semillas.

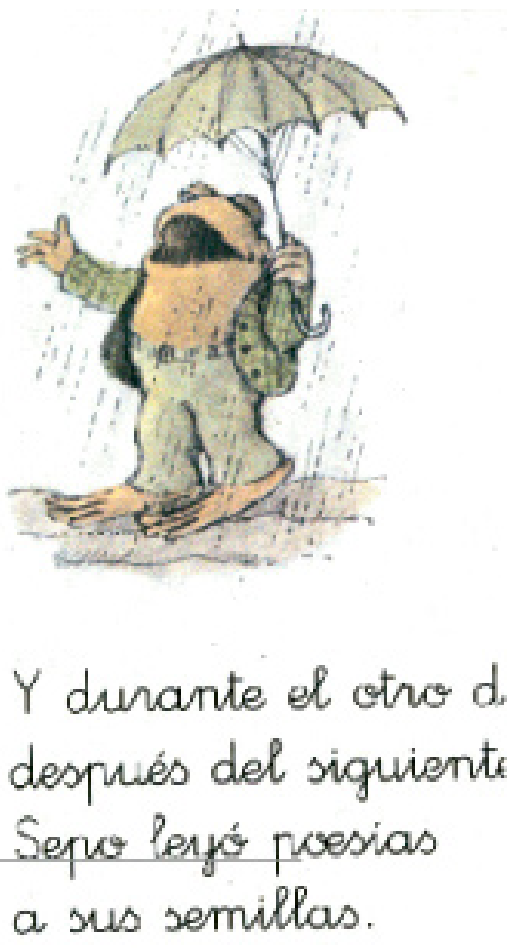

Fig. 30. Sapo y Sepo, inseparables. 
114 Otras formas de contar: los paratextos en el discurso narrativo infantil

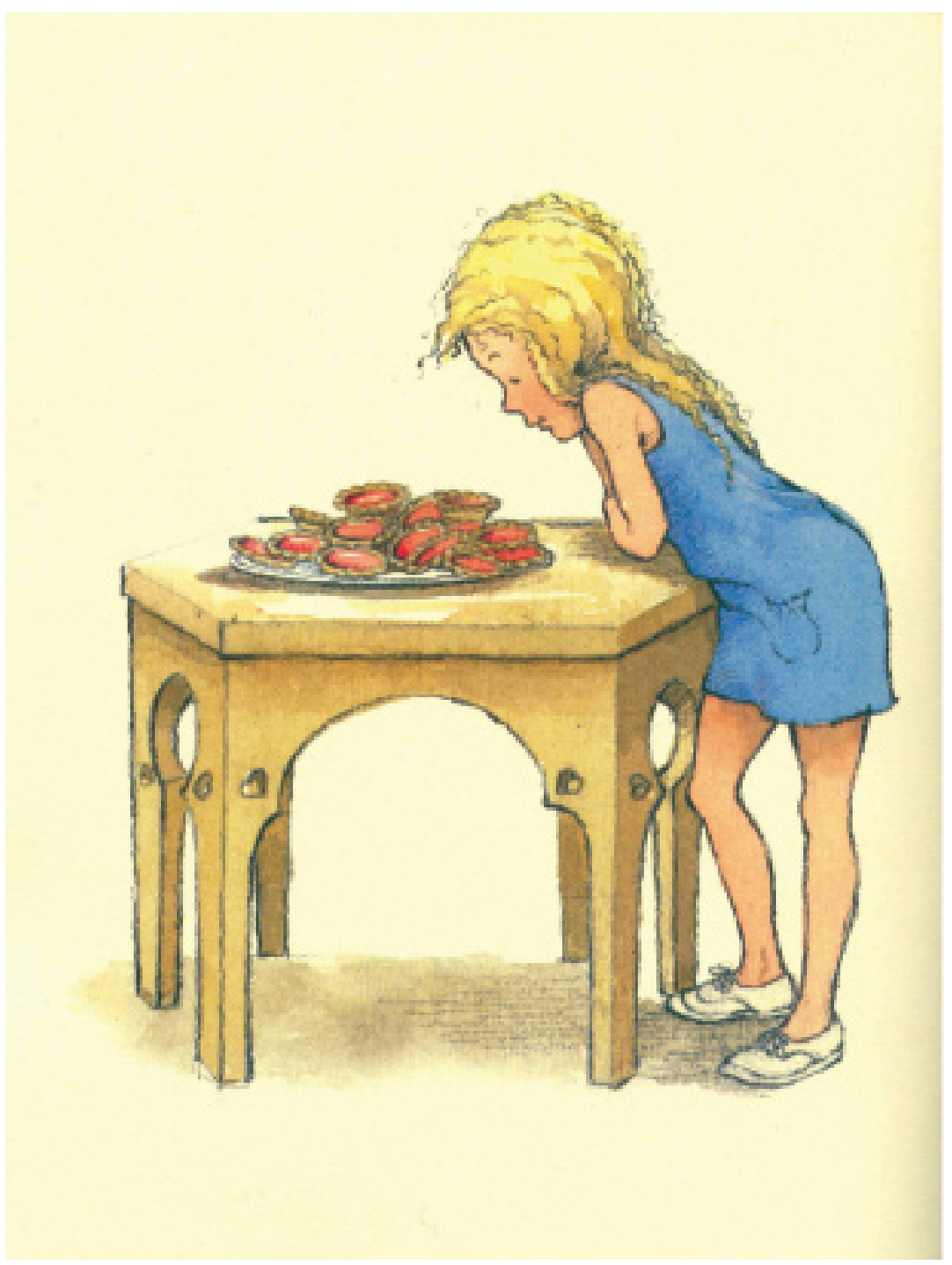

Fig. 31. Alicia en el país de las maravillas. 


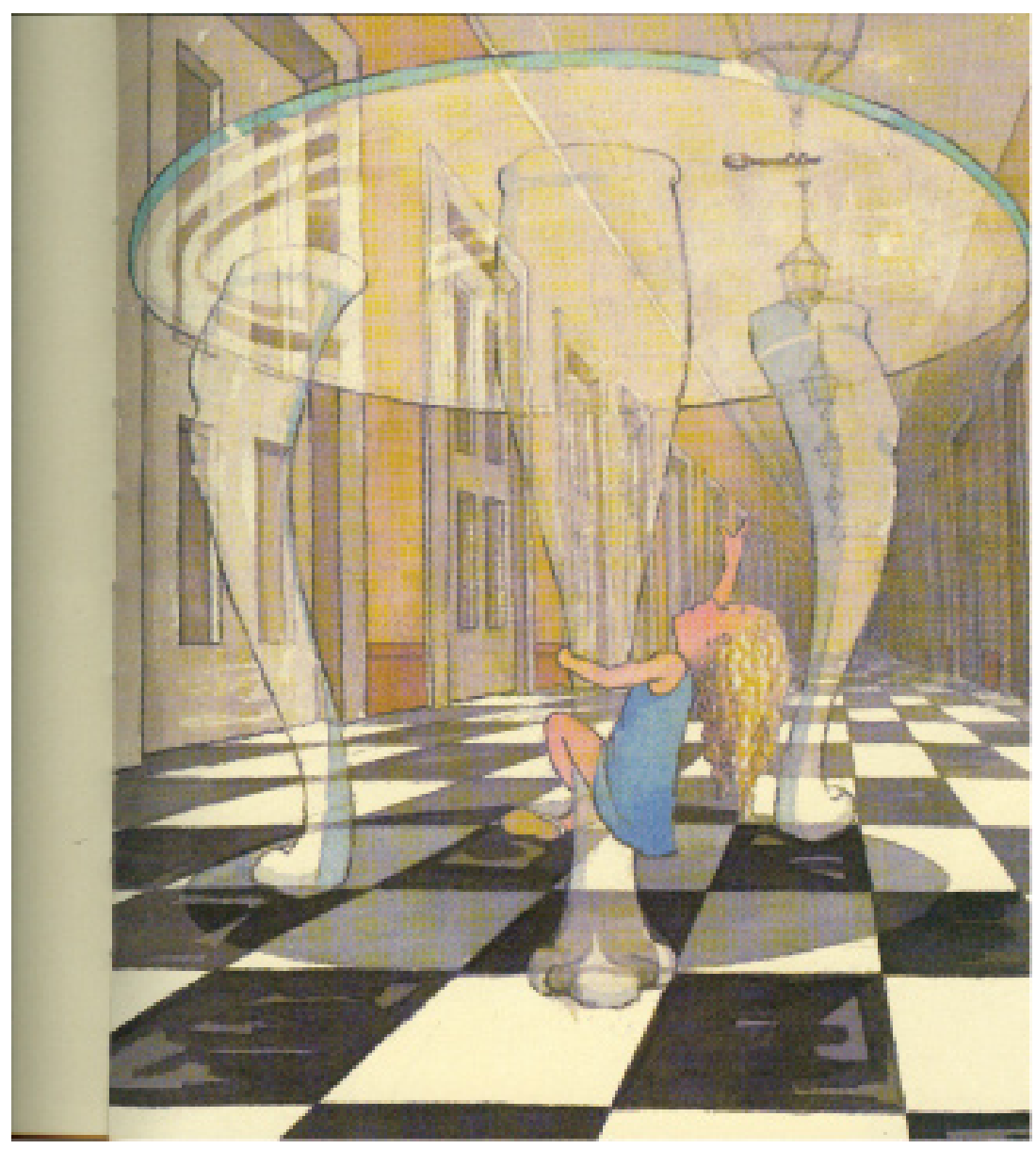

Fig. 32. Alicia en el país de las maravillas. 


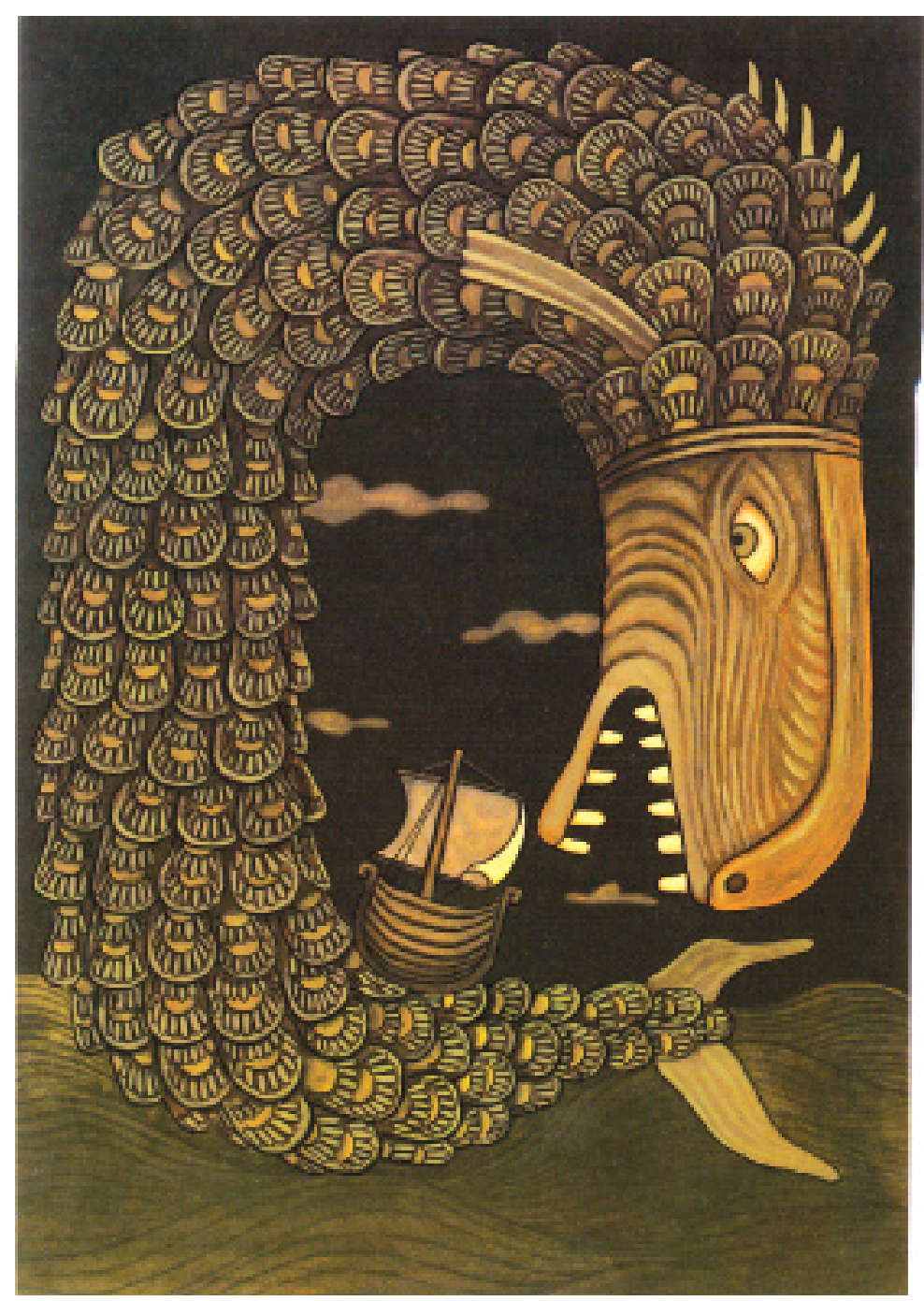

Fig. 33. Las mil y una noches. 


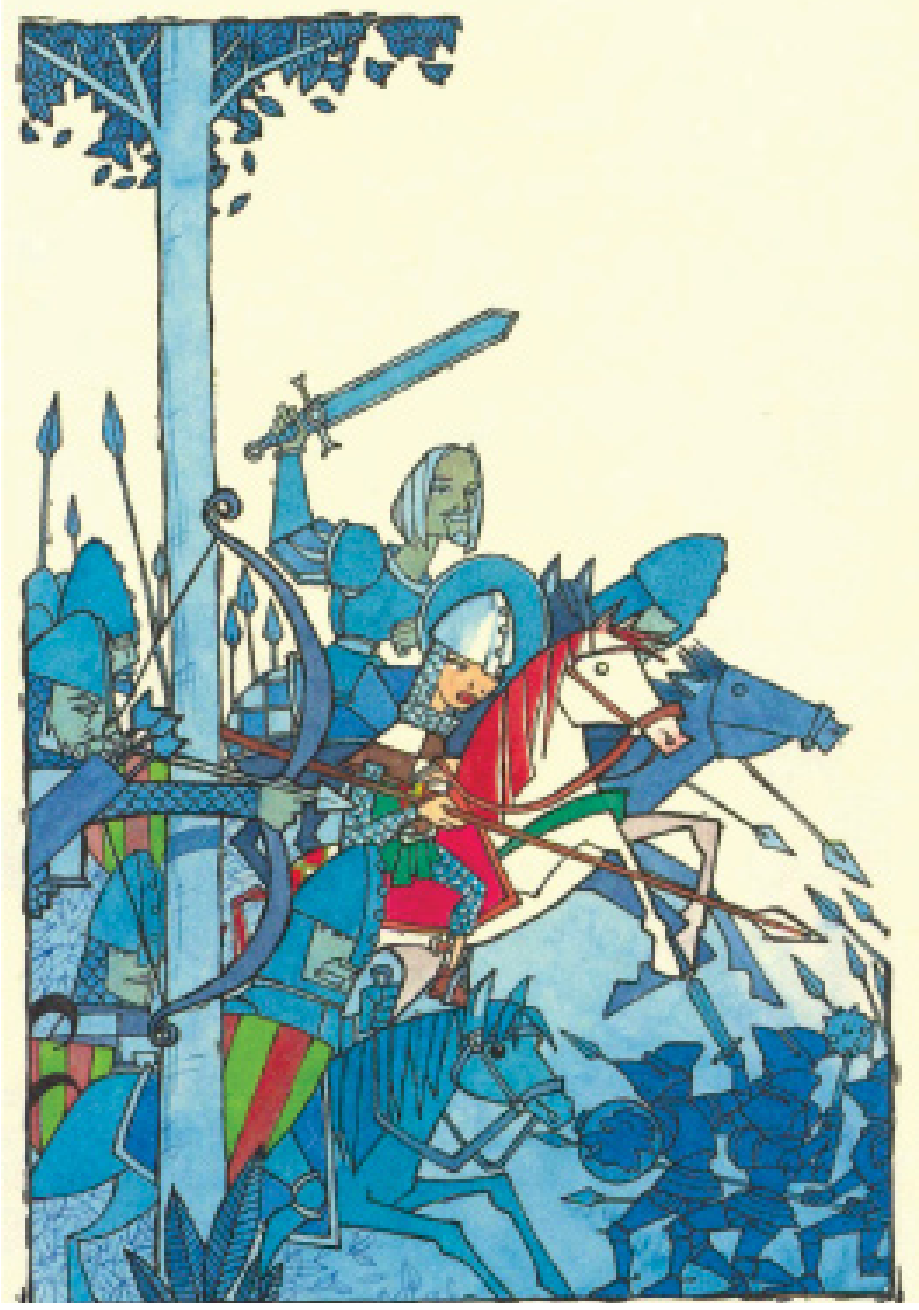

Fig. 34. La doncella guerrera. 
118 Otras formas de contar: los paratextos en el discurso narrativo infantil

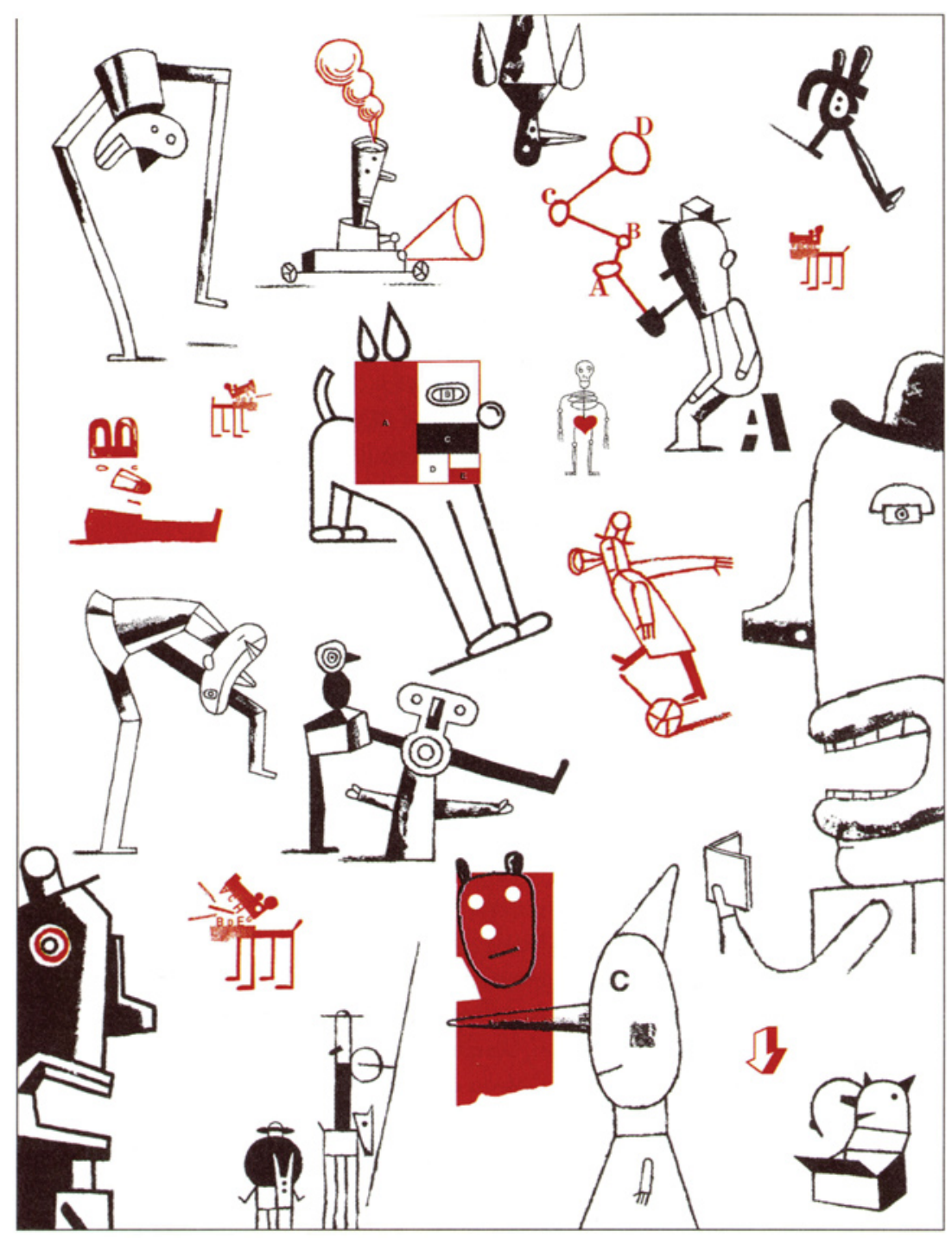

Fig. 35. El alfabeto que no llegaba a la $i$ 
En algunas ocasiones, el texto de la contracubierta no es tan explícito en los mensajes enviados al adulto responsable de la mediación. Se opta, sin embargo, por resumir el argumento, de principio a fin, ofreciendo, de esta forma, un texto en el que la enseñanza que el adulto suele buscar se infiere sin mayores complicaciones. Reproducimos a continuación dos ejemplos de diferentes editoriales de paratextos:

¡Sapete y Pajarita están en peligro! Sólo podrán salvarse si aprenden a mirarse. (A partir de 4 años) Bruño. Chiqui Cuentos (Puncel y López, Barquichuelo de papel).

Quedarse dormido solo no es tan fácil. Menos mal que papá acude rápido a la llamada de peligro. Da igual que sean los tiburones que rodean el barco pirata, o una legión de momias o de monstruos, o seres terroríficos y animales salvajes, con sus "terribles» amenazas. Todos se alejan ante la presencia de papá. Entonces llega el sueño tranquilo (Cano y Giménez, iiiPapááá...!!!).

¡Ay, si los padres de Fernando no estuvieran siempre tan ocupados!... Se quedarían asombradísimos al saber qué cosas tan extrañas ocurren en su propia casa... (McKee, Ahora no, Fernando).

Al pequeño Salustiano le dan de cenar temprano. Y papá juega con Flor que es la hermana mayor. $\mathrm{Y}$, mientras, ¿qué hace Julieta? Esperar y estarse quieta (Wells, jJulieta, estáte quieta!).

No discutimos la presencia de un receptor infantil pero subrayamos, sin duda, la recepción adulta en la que se inscriben estos textos. Explícitamente el editor o el director de la colección no se dirigen al receptor adulto; sin embargo, el contenido de lo que allí se expresa interesa sobremanera a la persona que va a recomendar el libro o que lo va a comprar.

En las obras recomendadas a los lectores de seis años en adelante, los textos de las contracubiertas no presentan resúmenes de argumentos sino que plantean el punto de partida de los mismos generando en el lector ciertas expectativas que pueden o no cumplirse. A este tipo de texto se añade una breve nota biográfica del autor en la que se insiste en los premios literarios que ha obtenido y en la trascendencia de su obra en el ámbito de la narrativa infantil. 


\section{CONTRACUBIERTAS}

Arnold Lobel. Nació en Los Ángeles, California, en 1933. Estudió en Nueva York y se casó con Anita, otra prestigiosa ilustradora. Con la serie Sapo y Sepo, Lobel se ha convertido en un clásico de la literatura infantil. Por ella, recibió en 1973 la importante medalla Caldecott.

A Sapo y a Sepo, una vez más se les ocurren las cosas más inesperadas: desde llenarse la cabeza de ideas para que a Sepo le quede a medida el sombrero que Sapo le regaló el día de su cumpleaños, hasta elevar una cometa a voces. Eso sí, ocurra lo que ocurra, la amistad entre ambos es inquebrantable (Lobel, Días con Sapo y Sepo).

Pancheta tiene seis años y es hija única. Tiene muchísimas ganas de ir a la escuela y conocer a sus compañeros. Pero Pancheta también es bruja. Por eso, tendrá que esforzarse mucho si quiere tener amigos. (Alcántara, ;Huy, qué miedo!).

El padre de Ana se quedó boquiabierto cuando su hija le pidió dinero para comprarse una goma de borrar. Y la verdad es que Ana tenía trescientas veintidós gomas: en forma de plátano, de limón, de coco, de caramelo, de chocolate, de chirimoya... Pero la goma que ella quería era una goma muy, muy especial.

PILAR MATEOS cuenta con una larga actividad en el mundo infantil tanto en el terreno de los libros como a través de la radio y de la televisión. En 1981 consiguió el premio «El Barco de Vapor» y en 1982 el premio "Lazarillo».

De esta autora, Ediciones SM ha publicado: Historias de Ninguno, Jeruso quiere ser gente, Capitanes de plástico, Lucas y Lucas, Molinete, La bruja Mon y La isla menguante, en la colección «Barco de Vapor», y Zapatones, en la colección «Cuentos de la Torre y la Estrella» (Mateos, Quisicosas).

Ha publicado libros de poemas, cuentos y ensayos, y es muy conocido como novelista. En 1973 empezó a escribir libros para niños que se caracterizan por la actualidad de su problemática y su autenticidad. 
Karli pierde a sus padres y es educado por su abuela. Tanto Karli como la abuela tienen que cambiar para adaptarse y convivir sin tensiones. Pero vencen las dificultades y acaban siendo muy buenos amigos. Este libro recibió el Deutscher Jungedbuchpreis en 1976 (Härtling, La abuela).

Mientras un ojo sueña, el otro se mantiene abierto a la realidad y al absurdo. GABRIEL JANER MANILA, Premio Nacional de Literatura y nominado para el Premio Andersen, nos ofrece una serie de relatos, cuentos breves, incisivos y mágicos, bellamente explicados. Ágilmente escritos y sugestivos, estos cuentos cosntituyen una invitación al mundo poético, irónico y humano, líricamente lúdico, del propio autor (Janer Manila, Cuentos para los que duermen con un ojo abierto).

ROALD DAHL nació en 1916 en el País de Gales. Ingenioso, divertido, dotado de una explosiva imaginación, está considerado como un indiscutible maestro de la literatura infantil. Su libro Charlie y la fábrica de chocolate obtuvo el número 1 en una encuesta realizada por el Sunday Times para elegir los diez mejores libros de todos los tiempos.

Matilda es genial. Sin haber cumplido los cinco años ha leído ya a numerosos autores y atesora unos asombrosos conocimientos. Sus mediocres padres, sin embargo, la consideran una inútil. Por eso, decide desquitarse. Y cuando empieza a ir a la escuela y se enfrenta a la terrible señorita Trunchbull, entonces la niña hace algo maravilloso... (Dahl, Matilda).

En estas edades la historia se deja planteada a la espera de que comience a desarrollarse el nudo. Una vez más consideramos que el doble destinatario es ineludible. En primer lugar, las noticias acerca del autor interesan más al adulto que al lector infantil que prescinde del currículum del autor. En segundo lugar, tanto en el primer texto como en el tercero, los valores que se trabajan en el libro, tales como la amistad o la integración, quedan patentes en los discursos de la contracubierta. Por otra parte, el receptor infantil de estas edades pocas veces consulta la contracubierta del libro, a no ser que en ella se encuentre la respuesta a ciertas cuestiones propuestas en los comentarios de texto. 
Conforme se va avanzando en la edad de los receptores, se insiste, dentro de este peritexto que estamos analizando, en cuestiones de estilo y temática más que en el perfil biográfico del autor. Se adelantan, de esta forma, el subgénero en el que la obra se enmarca, la temática que el autor trabaja generalmente y un breve resumen del planteamiento de la acción destacando las características del personaje principal. La mayor competencia del lector, así como la mayor exigencia del adulto mediador, permite adentrarse en rasgos de definición del personaje. El receptor adulto juzgará por las informaciones que en el texto de contracubierta se insertan si la narración se adecua a sus necesidades.

Los paratextos que acabamos de reproducir se centran, por una parte, en cuestiones de estilo del autor y adelantan, como ya es habitual, el planteamiento de la historia. Una vez más, el doble destinatario se adivina en los contenidos de los textos de la contracubierta. El lector infantil se interesará, sobre todo, por la presentación de la trama — Karli es educado por su abuela; Matilda se enfrenta a sus padres y a su profesora-. El lector adulto, en cambio, fijará su atención en la línea educativa trazada implícitamente por el argumento - respeto a los mayores, binomio educativo abuela-nieto (cf. Soriano, 1995); mundo poético; presencia de una niña prodigio que ha atesorado a su edad numerosas lecturas.

Sin duda el reflejo del doble destinatario es evidente en el texto de contraportada que aducimos a continuación:

Manolito Gafotas es un niño de Carabanchel que mira el mundo desde su barrio y cuenta todo lo que ve con las palabras que atrapa de los mayores, de las películas y de la televisión. Con su abuelo Nicolás, su hermanito El Imbécil, sus amigos Orejones López, Yihad y Susana, Manolito Gafotas es capaz de vivir los hechos cotidianos como aventuras estupendas: leyéndolas se comprende que la infancia es el mejor momento de la vida (Lindo, Manolito Gafotas).

Aunque la edad del receptor se escape de los límites de este trabajo, nos ha parecido de sumo interés la presentación de este paratexto indiscutiblemente pergeñado para el lector infantil-juvenil y para el receptor adulto, al que se dirigen especialmente las dos últimas frases que aluden indirectamente al recuerdo de la infancia perdida.

Del mismo modo, es digno de reseñar el texto que aparece en la contracubierta de la obra No quiero el osito de McKee, texto en el que se sugie- 
ren posibles y variadas lecturas que indudablemente no pertenecen únicamente a la interpretación del receptor infantil:

La rivalidad que establecen dos niños sobre sus osos le sirve de pretexto al autor para ofrecer unas inquietantes imágenes de su entorno. El libro tiene otras posibles lecturas, un poco surrealistas, de la realidad circundante que el lector tendrá que recomponer como un puzzle, a partir de una lectura de imágenes muy creativa.

Al texto que acabamos de ofrecer hay que añadir un fragmento de la misma narración en el que el editor, dentro del peritexto que estamos analizando, presenta al autor de la obra incluyendo frases textuales del propio autor que contribuyen a dirigir la interpretación de la obra por parte de un receptor adulto:

David McKee ha publicado muchos libros para niños. Algunos han tenido tanto éxito que el autor ha hecho películas de dibujos animados para la televisión. «Me gusta el humor encubierto y surreal. En los libros que ahora estoy haciendo me gusta dejar cada vez más cosas sin decir pues así hay más de una manera de interpretarlas». Este libro es un buen ejemplo de ello.

Sólo nos resta aludir, para terminar la referencia a los textos de la contracubierta, a su ausencia en el álbum ilustrado. En este tipo de obras lo más que aparece en la contracubierta es una lista de obras publicadas en la misma colección —Donde viven los monstruos, ;Adiós, pequeño!- Lo normal es que aparezcan ilustraciones referentes al contenido del álbum $-T \dot{u}$ y yo, osito, ;Papá! - L Los editores respetan en estas obras el poder persuasivo del componente icónico que, como hemos señalado anteriormente, influye sobremanera en el receptor adulto y, de esta modo, se insiste en el marco experimental de propuestas muy abiertas —emisión, mensaje y recepción- en el que se mueve este subgénero que, por otra parte, suele corresponder a la emisión de un solo autor que crea texto verbal e ilustración simultáneamente.

Los prólogos y las dedicatorias son paratextos que dependen asimismo de la mano del editor o del director de la colección. En el caso de la narrativa infantil, estos textos no suelen aparecer, tal como señala Lluch (1998: 92). Aparentemente los prólogos suelen dirigirse al lector infantil a través de una estructura imprecativa, aunque el destinatario último sea el adulto. Así, la editorial Bruño en la colección denominada Altamar inicia 
todas las obras con una ficha bibliográfica del autor, seguida de una dedicatoria a manera de prólogo escrita por el propio autor.

\section{PRÓlOGOS Y DEDICATORIAS}

Para ti

Coge un poema y súbelo, verso a verso, hasta llegar a la intención del poeta. Abre una novela y camínala, página a página, hasta que te sientas parte de las desventuras de un hambriento o de la fama del capitán que volvió de las estrellas.

Carga con tus dudas y entra en la biblioteca. Ahí están las respuestas de que dispone el hombre. No son todas las que el hombre quisiera, pero de momento es lo que hay.

Lee, muchacho, llena las maletas, pero no por eso dejes de correr, brincar y reír, cantar y enamorarte. La vida también es un buen libro y merece la pena vivirlo con alegría (Farias, Los apuros de un dibujante de historietas).

Querido amigo:

Cuentos para los que duermen con un ojo abierto es una invitación al juego de vivir la apasionante aventura del sueño. Un sueño que se extiende sobre las cosas cotidianas, sobre la vida.

Uno de los ojos sueña, mientras el otro se mantiene abierto a la realidad y al absurdo.

Vacas que escriben cartas de amor, palabras que se pierden, princesas que querrían vivir en el corazón de una manzana, trenes que parten por caminos insospechados, velas que se convierten de súbito en una paloma blanca...

Casi un delirio, una nave de locos es este libro.

Una propuesta incitante que te invita a participar en el juego de ver las cosas, discretamente con un ojo abierto.

Vuelve la hoja, amigo iy adelante!

(Janer Manila, Cuentos para los que duermen con un ojo abierto). 
Estos prólogos que, en realidad, constituyen una persuasiva y didáctica animación a la lectura, muy cercana a lo que la retórica antigua denominaba captatio benevolentiae, van acompañados de una serie de actividades que versa sobre el comentario de la narración. Sorprendentemente, en el primer caso, el número de páginas que ocupa el relato — 50 páginases menor que el número dedicado al comentario de texto —60 páginas-. Además, las actividades que se proponen desvirtúan el valor literario del texto utilizándolo como pretexto con una finalidad espuria. Extrañará, sin embargo, al lector que planteemos en el siguiente capítulo la existencia de otro tipo de prólogos cuya responsabilidad atribuimos únicamente al autor y que, por lo tanto, adquieren una dimensión especial en la recepción de la obra. Justificamos nuestro criterio basándonos en el diseño de la colección. Los prólogos a los que nos hemos referido en este apartado constituyen para el autor que los firma un requisito ineludible exigido por el diseño de la colección y, como se habrá podido comprobar, aluden vagamente al contenido de la obra tomándola como pretexto para recomendar la actividad de la lectura.

Tanto las dedicatorias como las actividades propuestas están dirigidas no a cualquier lector sino a los maestros, de acuerdo con la búsqueda y persecución del mercado escolar que tan rentable resulta. El maestro asimismo es, junto al librero y bibliotecario, el receptor elegido para las actividades de promoción y difusión de la lectura.

\subsubsection{Los catálogos}

Los catálogos, en la línea de promoción y difusión de la lectura, son los paratextos que más nos interesan. Este tipo de documentos pertenecería a lo que Genette (1987: 316) denomina epitexto.

Cualquier catálogo de narrativa infantil que llegue a nuestras manos insistirá no en la vertiente literaria de los títulos presentados sino en la función educativa: una vez más, es el circuito escolar el que la mayoría de los editores persigue. Consideramos, pues, de suma importancia para el análisis de la narrativa infantil desde el punto de vista pragmático la profundización en estos documentos de promoción a los que las editoriales reservan una parte de su presupuesto digna de tener en cuenta. Con esta finalidad, hemos analizado catálogos correspondientes a editoriales representativas - no queremos decir con ello que estén todas- en el área de 
literatura infantil en nuestro país. En algunos casos, hemos seleccionado unas publicaciones que desempeñan la función de catálogos de una forma más ambiciosa, puesto que acaban convirtiéndose en verdaderos manuales de auxilio para los adultos. No piense el lector que aquí están representadas todas las editoriales ni siquiera las mejores. Asimismo, no podemos dejar de insistir en que este tipo de epitexto es efímero puesto que, en principio, suele generarse cada año con la finalidad de comercializar los productos editoriales.

En lo que concierne al formato de los documentos escogidos, es necesario destacar que todos ellos constituyen publicaciones muy cuidadas en su presentación, muy atractivas visualmente y, como es de rigor, las ilustraciones basadas en las portadas de los libros presentados presiden todos los comentarios que sobre los textos se realizan. Excepto en la publicación de SM, el papel satinado y los múltiples colores en las portadas son las notas características de este tipo de libros.

Todos los documentos examinados comienzan con una «declaración de intenciones» de la editorial en la presentación de las diferentes colecciones. En ellas se adivina que el receptor de los catálogos no es el niño, ni mucho menos, sino el mediador adulto, en forma de librero, maestro o padre. Es destacable, por otra parte, el interés por adentrarse en el mercado escolar de algunos de los textos que introducen las colecciones presentadas.

Pero EDITORIAL BRUÑO no ha querido hacer una oferta más entre las que existen en el mercado. Su perspectiva es diferente e innovadora porque en sus colecciones ofrece a los lectores además del placer de su lectura, la posibilidad del disfrute de un mayor enriquecimiento intelectual y cultural al combinar perfectamente lo lúdico con lo educativo.

Para llevar a cabo este "proyecto interesante y atrevido", según los críticos, ha contado con la ilusión, el esfuerzo y la profesionalidad de un gran número de escritores e ilustradores de primera fila que han puesto y siguen poniendo su confianza en este planteamiento que ha sabido captar la realidad de nuestras aulas (Catálogo de publicaciones generales. Bruño. 1993-1994: 3).

Se insiste, por lo tanto, en la necesidad de combinar los elementos lúdicos y didácticos, por una parte, y en la recepción del elenco de lecturas por parte de los maestros, lo cual queda todavía más claro en la presentación de la colección Altamar, la más vinculada a las obras de creación literaria: 
Recoge obras de actuales y prestigiosos autores españoles y extranjeros en los distintos géneros literarios. Incluye en cada libro una ficha informativa coleccionable de cada escritor y una dedicatoria personal del autor. Aporta un amplio comentario de los textos para que el lector adquiera, con un método activo, el hábito de la lectura inteligente, desarrolle su capacidad crítica y descubra los valores que las obras literarias encierran (Catálogo de publicaciones generales. Bruño. 1993-1994: 22).

La editorial Edebé insiste en las mismas líneas que la anteriormente citada. Aunque en la introducción se declara la finalidad de que «los niños y jóvenes no sólo descubran la lectura, sino que se entusiasmen con ella», en la presentación de cada una de las colecciones, se insiste implícitamente en la adaptación de las obras a las necesidades de las aulas, de tal manera que cada colección va acompañada de fichas dedicadas a cada una de las obras que se presentan. La estructura de las fichas es la siguiente: formato, edad recomendada, biografía del autor, biografía del ilustrador, argumento $\mathrm{y}$ actividades en forma de aportaciones y sugerencias.

FICHA EDITORIAL

EL FANTASMA DE LA ESCUELA de H. Towson.

Cubierta: a cuatro colores.

Ilustraciones: en blanco y negro.

$N .^{\circ}$ de páginas: 68.

Edad recomendada: a partir de 7 años.

Autora: noticia biográfica.

Ilustrador: Tony Ross. Noticia biográfica.

Argumento: introducción extensa. 


\section{ACTIVIDADES}

\section{Aportaciones:}

Parece que siempre pagan justos por pecadores, porque en este caso el pobre vigilante de la escuela recibe todos los porrazos. Sin embargo, al final vence la justicia, ya que Basil Nibbs no se libra totalmente del fantasma.

La falta de respeto por parte de un alumno hacia el maestro ha hecho que este último enloquezca. Unos años más tarde, un descendiente de aquel muchacho repite la misma historia sin saberlo. ¿Somos herederos del carácter de nuestros mayores?

El señor Browne ha tenido que vencer el miedo para poder expulsar de la escuela al fantasma pero lo paga muy caro. Esperemos que una heroicidad como ésta se vea recompensada.

\section{Sugerencias:}

El miedo. Todos hemos pasado miedo alguna vez; seguro que tú también. Explica la vez que más te has asustado.

El disfraz. Cuando hablamos de fantasmas, siempre pensamos en una sábana blanca con una bola de hierro, pero no sólo hay fantasmas así. También hay fantasmas que se pueden quitar la cabeza, fantasmas con forma de perro, fantasmas miedosos, etc. Invéntate un fantasma y haz una lista del material necesario para disfrazarte. Si te vistes así en Carnaval, seguro que sorprenderás a todo el mundo.

Valga la ficha anterior como modelo de todas las que se presentan en el catálogo de la editorial Edebé para evidenciar el receptor al que van dirigidas estas publicaciones, que no es otro que el maestro, quien, a su vez, si lo considera oportuno, recomendará a sus alumnos la obra propuesta para trabajarla en clase posteriormente.

En esta línea se presenta el libro titulado 100 nuevos Barcos de Vapor (1990), publicación destinada, tal como reza el prólogo, «a cuantos se dedican al mundo del niño y el libro: padres, educadores, responsables de 
grupos juveniles, bibliotecas, animadores, etc.». Una vez más, son los adultos los receptores elegidos. Cada una de las fichas analíticas, organizadas por edades según la enseña de la sección, incluye una nota biográfica acerca del autor, una sinopsis argumental y dos apartados dedicados al interés del libro y a las actividades que a partir de él se pueden plantear. En lo que se denomina «interés del libro» se refleja el tratamiento de los valores temáticos más sobresalientes, destacados, sobre todo, por la función didáctica.

LA REINA CALVA de M. Company.

Interés del libro. El libro nos transmite la preocupación de una reina por tener pelo, pero esta preocupación no está rodeada por la fatalidad o la desgracia, sino por la ilusión y la esperanza.

Es importante el tratamiento que se da a la justicia. La reina recompensa a todos con algo que les hace ilusión y con su premio no pretende que su hijo se case sin estar enamorado, ya que ella valora mucho el amor (100 nuevos Barcos de Vapor, 1990: 68).

Susaeta, en este sentido, presenta sus colecciones destacando la edad a la que van dirigidas y la finalidad que persiguen, además de la asequibilidad del precio.

Colección Duende: De 5 a 12 años.

Especial calidad de texto e ilustración. Color en todas las páginas. Autores e ilustradores, españoles y extranjeros, de gran prestigio. Contenidos atractivos y cercanos al niño. Libros que enseñan a vivir. Precio muy asequible.

La editorial Alfaguara, en el catálogo titulado Tendencias (1992), mostraba ya una línea diferente de la que hemos comentado hasta ahora. Los criterios expuestos en el prólogo no parecen tan orientados hacia el mercado escolar sino más bien a la oferta de una literatura de calidad guiada por unos parámetros no únicamente educativos.

Los criterios básicos para la formación del fondo de libros Alfaguara para niños han sido históricamente tres: el primero, atender a la calidad literaria por encima de cualquier tentación de facilidad presuntamente "comercial»; el segundo es que la literatura infantil es tan sólo un término convencional para agrupar una serie de obras que, ante todo y sobre todo, son literatura, o, lo que es lo mismo, que sólo hay una literatura sea cual sea el grupo de lectores que se interese por ella o que interese al escritor en cada caso; el tercer criterio es la fidelidad a una política editorial de autor, por lo que se pretende la publicación del máximo de obras de un mismo escritor de forma que éste quede incorporado esencialmente al sello editorial (Tendencias, 1992: 3). 
Obligado es detenernos en el análisis de este texto por la trascendencia de lo que en él se afirma. Nada debemos objetar a los criterios primero y tercero esgrimidos por la editorial. Es necesario, sin embargo, analizar con cierto detenimiento el segundo criterio. No nos parece muy adecuado aludir a la convencionalidad del término literatura infantil, puesto que resulta obvio que toda etiqueta que pretende facilitar una clasificación es convencional. Estamos de acuerdo, no obstante, con la idea, evidente por otra parte, de que la literatura infantil es ante todo literatura. Es necesario recordarlo puesto que la industria editorial de la actualidad, tal como hemos reseñado, se muestra preocupada por ofrecer productos de mercado que faciliten la tarea al maestro, escogiendo asimismo las obras publicadas en función de la finalidad didáctica, finalidad que no siempre es compatible con los parámetros propios de la calidad literaria. De este modo, la editorial que acabamos de mencionar no ofrece prólogos de diseño de colección, ni listas interminables de ejercicios para realizar en las aulas, etc., al menos no los adjunta a la edición de la obra. Se podrá discutir la elección de los títulos publicados - traducciones muchos de ellos - pero no los criterios en los que se sustenta esta colección que está orientada preferentemente, como se infiere de los análisis de los catálogos y de las cadenas de distribución, hacia las bibliotecas y librerías, aspecto que coincide con los canales por los que camina la literatura para adultos. Sí observamos, en cambio, una orientación al mercado escolar en el catálogo que la misma editorial ofrece en el curso 2000-2001. El catálogo al que hacemos referencia presenta las diversas series que Alfaguara ofrece en el mercado orientadas a la educación primaria: verde — primeros lectores-, amarilla — desde 6 años—, morada — desde 8 años—, naranja — desde 10 años—, azul —desde 12 años—, Alfaguay ${ }^{20}$ e Historias de Siempre. ${ }^{21}$ En el

20 Hemos comentado en el primer capítulo cómo la literatura infantil no ha adquirido todavía la categoría que le corresponde. A este respecto, no resulta superfluo referir textos como el de presentación de la colección Alfaguay: «Alfaguay es literatura de calidad de la mano de los grandes escritores españoles de hoy: Manuel Rivas, Lindo, Montero, Sierra i Fabra, E. Antolín, Plans, Juan Madrid... Alfaguay es diversión, aventura y acción... para los lectores más exigentes a partir de los diez años de edad» (Catálogo 2000-2001. Primaria. Contigo creamos lectores: 42). ¿Quiere esto decir que los demás libros referidos en el catálogo no son de calidad?

21 Observamos, no sin sorpresa, que la editorial presenta en el catálogo de educación primaria la serie azul — desde 12 años—, correspondiente a la educación secundaria. 
prólogo de la publicación analizada se exponen los presupuestos de los que parte la editorial, que esta vez se orienta fundamentalmente al ámbito escolar:

\section{Prólogo CATÁlogo EDitorial}

Entre las iniciativas de Alfaguara para apoyar al profesor en su labor docente, tenemos los siguientes materiales para los profesores que deseen utilizarlos:

- Carpetas temáticas, que surgen del compromiso adoptado por la Editorial Alfaguara con la sociedad y la educación. En ellas se agrupan los títulos más indicados para tratar en profundidad temas que nos afectan. [...] En la carpeta temática, el profesor encontrará, como en campañas anteriores, fichas con las que obtener el mayor rendimiento educativo de cada uno de los títulos, con actividades relacionadas con el tema.

- Este año ofrecemos nuevos programas de actividades con un enfoque curricular completo; fáciles de utilizar y llenas de ideas para estimular el placer lector en el aula y el aprovechamiento del libro en todas sus facetas: vinculado a áreas, con unos objetivos claros, con el tratamiento de temas transversales, juegos, etc. (Catálogo 2000-2001. Primaria. Contigo creamos lectores: 2).

Por otra parte, cada serie está introducida por un cuadro en el que se reflejan las diferentes áreas transversales (educación para la convivencia, para la salud, para la paz, del consumidor, no sexista, ambiental y multicultural) trabajadas en cada uno de los títulos referidos. Cada título va acompañado por un resumen del argumento y una referencia a los temas, áreas, ejes transversales y celebraciones a las que se vincula. Los títulos seleccionados para el proyecto Leer, leer, leer... Contigo creamos lectores parecen ser aquellos que destacan por su calidad literaria a criterio de la editorial.

Una vez más, los receptores del catálogo son los adultos, sobre todo los maestros que llevan a cabo la elección de las lecturas implicadas en cada curso escolar. 
Además del mencionado anteriormente, los catálogos del curso 2000$2001^{22}$ presentan las mismas características que los anteriormente analizados. Continúan siendo ediciones muy cuidadas en las que las colecciones y cada uno de sus títulos van acompañados de fotografías e ilustraciones propias del material presentado. La orientación de este tipo de catálogos sigue siendo acentuadamente escolar y se insiste sobremanera en el formato de los libros y en la ilustración de los mismos.

Por eso queremos que nuestro catálogo sea algo más que un listado de colecciones, títulos, formatos y premios. Sin duda, todo eso es una información importante que interesa conocer. Pero junto a ella queremos transmitir una pequeña parte de esa vida que llevan los libros en su interior: temas, ilustraciones, diseño y tantas cosas más que constituyen una parte vital del libro que trata de transmitirse y que sólo se completa cuando el lector la recibe y la incorpora a su andadura (Libros infantiles y juveniles. SM. Introducción, Madrid, SM).

La atención al lenguaje icónico se extrema en estos catálogos adaptándose de este modo a un receptor acostumbrado al mundo de la imagen como corresponde a los nuevos tiempos.

En los catálogos que ofrece la editorial Anaya se insiste en la introducción de los títulos publicados en el ámbito escolar. Con este fin presenta de cada una de las obras el objetivo que se persigue, además de un apartado dedicado a las actividades sugeridas. Presentamos a continuación un ejemplo de lo que se adjunta a cada libro.

22 Han sido consultados los catálogos correspondientes al curso 2000-2001 de las editoriales SM y Anaya (Libros infantiles y juveniles, Madrid, SM, 2000; Leer. Lecturas recomendadas, Educación Infantil. Curso 2000-2001; Leer. Lecturas recomendadas. Primaria. Primer ciclo. Curso 2000-2001; Leer, Lecturas recomendadas. Primaria. Segundo ciclo. Curso 2000-2001; Leer. Lecturas recomendadas. Primaria. Tercer ciclo. Curso 2000-2001, Madrid, Anaya), Juventud (2001. Catálogo general, Madrid, Juventud), Alfaguara (Catálogo 2000-2001. Primaria. Contigo creamos lectores, Madrid, Alfaguara) y Noguer (Literatura Infantil y Juvenil. Noguer crea lectores, Barcelona, Noguer). Obsérvese que los catálogos se estructuran temporalmente siguiendo los períodos marcados por el desarrollo de un curso.

Los catálogos consultados con posterioridad a esas fechas no han introducido modificaciones considerables. Por esta razón hemos considerado que la incorporación de los mismos no aportaba - excepto en algún caso- nada nuevo. 
D. McKee, ELMER Y EL TIEMPO

\section{LA LECTURA}

Todos percibimos desde temprana edad los cambios de tiempo y las incomodidades propias de cada fenómeno que se produce en la atmósfera. Pero, en esta ocasión, los pequeños tendrán la oportunidad de conocer los aspectos más positivos porque, al igual que Elmer, pueden aprender a pasarlo bien.

A Elmer le gusta el viento, la lluvia, la tormenta, la niebla, la nieve... y es que cada circunstancia se presta a un tipo de juego, y él es un elefante tan divertido que da gusto estar con él.

\section{Algunas actividades sugeridas}

- Antes de leer, observaremos la cubierta. ¿Qué está haciendo Elmer? ¿Qué clase de gafas lleva? ¿De qué puede tratar el cuento?

- Podemos hablar de los lugares de veraneo (playa, montaña), y qué hacen (si están más tiempo con sus padres, con otros familiares...). Comentaremos las diferencias con lo que hacen en invierno: qué les gusta y qué no les gusta de estas dos estaciones del año tan opuestas.

- Después de leer el texto y observar las ilustraciones, entre todos, comentaremos diferentes formas de diversión para cuando llueve, hace viento, se produce una tormenta o calienta demasiado el sol.

- Repasaremos el cuento para imaginar cosas que dice Elmer en cada doble página del cuento.

(Lecturas recomendadas. Educación Infantil. Curso 2000-2001, Madrid, Anaya). 
El erizo de mar de Iela Mari

\section{Orientación pedagógica}

La forma de un objeto reproduce, mediante el proceso de abstracción de un niño pequeño, la paulatina transformación en otras cosas a partir de los elementos gráficos que sirven para identificar el objeto inicial. La vuelta al punto de partida (el erizo) imita el mecanismo de los juegos infantiles, donde prevalece la fantasía.

\section{ACTIVIDADES}

Antes de leer, cada niño dibujará una forma geométrica sencilla y la transfomará en un objeto o animal.

Haremos un mural en el que, a partir de una figura, cada niño vaya señalando una transformación (dibujada por él mismo o con ayuda del profesor). Luego contaremos la historia con esa secuenciación de figuras (el maestro/a deberá mostrar un ejemplo previo) (Anaya. Educación Infantil. Lecturas recomendadas, 2004).

En lo que concierne a los catálogos de Primaria de la misma editorial, la perspectiva escolar es, si cabe, bastante más clara, puesto que las lecturas se distribuyen siguiendo el orden de los cursos académicos por colecciones - El duende verde y Sopa de libros — y cada una de las obras, además de sugerir actividades para desarrollar en el aula, remite a un cuaderno anexo que versa sobre las posibilidades académicas de la obra en cuestión. De esta manera, se facilita la labor al maestro hasta extremos insospechados.

Bajo este planteamiento lo que subyace es una concepción de la literatura infantil como recurso educativo, como una actividad de base para acercarse a otras áreas de conocimiento. Estamos de acuerdo con la idea de que la literatura enseña, puesto que toda creación constituye siempre un pretexto para la reflexión. Sin embargo, creemos que la narrativa infantil, en ocasiones, se sujeta excesivamente a finalidades espurias.

No podemos terminar este capítulo sin referirnos a la creación de portales virtuales en los que se establecen guías de lectura y recomendaciones 
diversas. Así por ejemplo, SOL (Servicio de Orientación de Lectura. Ministerio de Educación, Cultura y Deporte. Federación de Gremios de Editores de España y Fundación Germán Sánchez Ruipérez) intenta desde el medio virtual ofrecer una selección de lecturas orientada a maestros, bibliotecarios y familias. Una vez más se vuelve a insistir en los valores educativos del discurso en detrimento de los puramente literarios. De hecho, las búsquedas son principalmente temáticas y cronológicas.

Después de lo expuesto hasta aquí, quizá conviniera a este respecto recordar las palabras de Savater (1988: 10):

En la literatura lo único inapelable y duramente instructivo es el deleite mismo. [...] Algo que hace disfrutar ya está enseñando algo y algo infinitamente difícil y precioso, lo más básico para vivir cuerdamente: está enseñando a pasarlo bien.

El epitexto editorial que hemos analizado posiblemente nos muestre el aspecto menos «literario» del discurso narrativo infantil. En él encontramos esas finalidades espurias de las que hemos tratado a lo largo de las líneas anteriores. La necesidad de enseñar, el componente comercial de mercado, la insistencia en el mediador adulto son factores que indudablemente contribuyen a caracterizar a un discurso que, en ocasiones, se muestra más pendiente de la mediación educativa y comercial que de la recepción última. $\mathrm{Y}$ es difícil que los autores se sustraigan a estos condicionamientos en la generación de su obra, claro está. Debemos insistir: es de literatura de lo que estamos tratando. 


\section{CAPÍTULO 3 DE CONTADORES, CUENTOS Y CONTADOS}

Vamos a intentar definir las claves del discurso narrativo infantil desde los presupuestos del enfoque comunicativo, puesto que la lectura de una obra literaria se realiza en presencia de un contexto específico, el de la situación comunicativa literaria (García Landa, 1998: 267). Así, Pratt (1977: 122) critica las definiciones intrínsecas del hecho literario porque ignoran que los textos ya llegan a manos del lector valorados por el juicio de lectores cualificados que les confieren el estatus de literarios. Desde la intencionalidad del autor, pasando por el camino de la aceptación social, llegamos a la acción individual del lector, puesto que algunos estudiosos han vinculado extremadamente la esencia de lo literario a una manera de leer el libro y no a una manera de escribirlo. ${ }^{1}$ En suma, la literatura es el uso de un texto, es la actuación conjunta de instancias como el emisor, el receptor y el contexto en el que la emisión y la recepción o interpretación se producen, siempre a través de un pacto narrativo que contribuye a definir el acto de comunicación. Es una práctica discursiva.

Pese entender de esta manera el hecho literario quizá lo primero que se debería plantear es el concepto de literatura. Evidentemente, no es éste el lugar para llevar a cabo tal empresa aunque recordemos a este respecto que conceptos como los de función poética, función lúdica, ficción, verosimilitud o género $^{2}$ contribuyen a definir la construcción referencial que llamamos literatura.

1 Cf. Adams, 1985: 9; y a este respecto: Lázaro Carreter, 1987: 153; Schmidt, 1987: 202.

2 Estudios como los de Ynduráin (1974), Eguren Gutiérrez (1987), Bousoño (1981), Pelegrín (1984), Todorov (1975), Aguiar e Silva (1997), García Landa (1998) abordan estos asuntos que resultan de especial relevancia en las aproximaciones a la literatura infantil. 
Por otra parte, ineludiblemente la creación de un mundo posible implica cierta visión de los valores humanos. Es utópico creer en la neutralidad ética del artista, como muy bien señala Ricoeur (1984: 94), ya que «impediría una de las funciones más antiguas del arte, a saber, la de constituir un laboratorio en el cual los artistas con la ayuda de la ficción llevan a cabo un experimento con los valores». En el caso de la literatura infantil, la presencia de la valoración ética es, si cabe, más tangible que en la literatura para adultos por las características del receptor al que va dirigida.

Centrándonos ya en el género narrativo, hablaremos de narración o discurso narrativo cuando denominemos un discurso que nos transmite un relato. Es el producto lingüístico de la actividad de un narrador. Aunque en algunas ocasiones nos referiremos a lo que en los niveles de análisis se denomina acción o relato, nuestra actividad se centrará prioritariamente en el estudio del discurso, ${ }^{3}$ puesto que, como señala Pozuelo Yvancos (1988: 245), «los personajes, las secuencias de acción, la perspectiva o las estructuras temporales del mundo narrado y del relato pasan a ser así elementos textuales, estructuras discursivas». Compartimos asimismo con García Landa (1998: 258) la idea de que el estudio del discurso debe remitir a las figuras del enunciador y de su receptor, así como a la situación comunicativa en la que se produce la narración. De este modo, el estudio de la enunciación narrativa debe incluir la enunciación efectiva — autor real y receptor real-y no sólo la enunciación ficticia del narrador, como ocurre en teorías narratológicas como las de Genette (1987a) o Bal (1995), que excluyen de sus exposiciones la enunciación y recepción efectivas además de las imágenes textuales del emisor y del receptor.

3 Adoptamos las definiciones que de los conceptos acción, relato y discurso ofrece García Landa (1998: 19-20): «En una definición provisional diremos que la acción consiste en la serie de acontecimientos narrados, y que el discurso narrativo es el proceso semiótico que elabora o transmite la narración. El relato es el terreno común entre ambos: la acción tal como aparece en el discurso. El relato es la representación de la acción en cuanto ésta es transmitida narrativamente, y el discurso narrativo (hay, claro está, muchos otros tipos de discurso) es la representación del relato. También podemos considerar al discurso narrativo la estructura superficial del relato y a éste la estructura superficial de la acción narrada. Inversamente, un relato es la estructura profunda de un discurso narrativo y una acción es la estructura profunda de un relato». Cf. Bal (1995) y la distinción que realiza entre fábula, historia y texto; y Garrido Domínguez (1993) con una diferenciación de niveles bastante menos clara. Al fin y a la postre, son tres los niveles de abstracción en este sentido: el material narrativo (los acontecimientos y situaciones), su combinación en una historia narrativa y la plasmación lingüística que se identifica con el discurso. 
Antes de definir en qué consiste la narración literaria, tomamos como base la descripción de la narración:

\footnotetext{
La narración es una realización lingüística mediata que tiene como objeto comunicar a uno o más interlocutores una serie de acontecimientos, para hacer participar a los interlocutores de dicho conocimiento, ampliando su contexto pragmático (Segre, 1985: 298).
}

La clave de esta definición se encuentra en la mediatez de la comunicación: lo narrativo se diferencia de lo dramático en la implicación de la ausencia o más bien en la presencia mediata. El narrador desempeña las funciones de intermediario entre el lector y el mundo narrado. Tanto la narrativa natural como la artificial, ${ }^{4}$ desde la teoría de los actos de habla, se definen como textos de exhibición (display texts). Son generalmente textos desligados de la situación de enunciación inmediata cuya reconstrucción debe realizarse a partir del propio texto, sin que el receptor posea más datos que los que provengan de su propia enciclopedia. Este hecho implica que el receptor observe un papel activo en el uso comunicativo del texto. De este modo, Eco (1987: 435) afirma que «la comprensión del texto se basa en una dialéctica de aceptación y rechazo de los códigos del emisor y de propuesta y control de los códigos del destinatario». El mismo estudioso (1987: 100), comparando la narrativa artificial con la natural, señalaba que la primera «abarca simplemente una cantidad mayor de cuestiones de tipo extensional». Si bien es cierto que los dos tipos de narración parten de los mismos conceptos básicos (modalidad narrativa, descripción, exposición, discurso directo o indirecto, voz, etc.), no es igual la distribución de los mismos. La narración literaria desarrolla estructuras que le son peculiares en su combinación.

En el marco de la narrativa infantil compartimos con Wall (1991) la idea de que en el estudio del discurso literario es necesario contemplar los seis términos esenciales de la comunicación literaria: autor/lector reales, autor/lector implícitos, narrador/narratario. Sólo trataremos de las dos últimas instancias mencionadas ya que la profundización en la pareja autor/lector reales implica una vertiente antropológica y sociológica que, si bien contribuye a cimentar el análisis del discurso literario infantil, implica la presencia insoslayable de parámetros contextuales que requerirían aisladamente un tratado aparte.

4 Cf. Pratt, 1977: 69; Ruthrof, 1981: 22. 


\subsection{El autor}

Habitualmente se tiende a identificar la figura del narrador con la del autor, sobre todo cuando se trata de una autobiografía. La reivindicación del autor surge en el siglo XX cuando las corrientes norteamericanas intentaron abolir la figura del narrador y, por ende, la del autor. Forster (1927), en un principio, y Booth (1974) trataron de salvar los fueros del autor a través de la elaboración de un nuevo concepto —el de autor implícito o autor textual- que se distingue tanto del autor real como del narrador. Según Booth (1974), se identifica con la imagen que el autor real proyecta de sí mismo dentro del texto. Se trata, pues, de una realidad intratextual, como señala Garrido Domínguez (1993: 116) —aunque no siempre explícitamente representada-, elaborada por el lector a través del proceso de lectura, que puede entrar en abierta contradicción con el narrador en algunos casos.

Autor y lector textual son inmanentes a la creación e interpretación de la obra, a su uso en tanto que discurso históricamente situado. García Landa (1998: 391-392) hace referencia a la falsa simetría, sólo justificable desde su presencia en el texto, que se establece entre autor implícito o textual y lector implícito o textual. Segre (1985: 19) contempla, en virtud de su naturaleza diferida, el circuito de la comunicación literaria. En la escritura de la obra el autor sólo dispone de la mitad del contexto, mientras que la circunstancia se invierte en el proceso de lectura, en el cual el lector real únicamente accede a la imagen textual del autor. Las parejas, atendiendo a cómo se reflejan en el fenómeno literario, son autor/lector textual y autor textualllector.

En el momento en que el receptor comprende la obra, se interpreta no sólo el acto ilocucionario directo del narrador sino también el acto ilocucionario indirecto del autor. El autor textual es una imagen del autor real que sufre una reducción descriptiva impuesta por la naturaleza misma del texto (Adams, 1985: 33). En este sentido, Booth (1974) ha propuesto la figura del autor implícito como la figura construida por el lector para dar cuenta del todo artísticamente completo de la obra. Así pues, de aquí en adelante, utilizaremos el término autor textual para dejar claro que este componente del acto comunicativo no siempre es una voz implícita sino que puede aparecer en el texto explícitamente. En definitiva, el autor textual es el producto de una estrategia interpretativa del receptor; es la imagen que el texto ofrece de su 
productor que sólo se modifica mediante la alteración del propio texto. En este capítulo trataremos únicamente del autor textual que se desprende de una obra y no de la totalidad de su producción, objetivo que exigiría un estudio monográfico. Nos interesa el análisis del autor textual en la medida en que contribuye a caracterizar la especificidad del discurso narrativo infantil literario. El autor textual suele mantener una ideología semejante a la del autor real pero no por ello debemos pensar en una coincidencia forzosa entre autor real y autor textual. Hay autores reales que deliberadamente se diferencian de su imagen textual.

Algunos estudiosos como Genette (1987, 1989a y 1998) o Bal (1995) niegan, aun aceptando su existencia, la necesidad de contemplar la presencia del autor textual en el estudio pragmático del discurso de ficción. Estimamos, sin embargo, que el análisis del autor textual es necesario, puesto que entendemos esta instancia como una estrategia interpretativa del discurso literario. Por tanto, el autor textual debe ser contemplado ya que en él radica una de las instancias discursivas que lo diferencian de la narrativa para adultos.

Cómo se manifiesta el autor textual en el texto es una de las cuestiones que debemos abordar. Es necesario desligar esta figura del plano del narrador. Algunos estudiosos (Adams, 1985: 60) niegan que el autor textual disponga de otro recurso que no sea el de la selección de lo narrado. Sin embargo, entendemos que, en la mayor parte de los casos, esa tarea corresponde al narrador. Títulos, prólogos, epígrafes, índices corresponden al marco en el que se desarrolla esta instancia enunciativa.

El autor textual puede presentarse en el texto de una forma más esquiva y difícil de discriminar a través de la ironía como procedimiento constructor del discurso, estrategia basada en que el destinatario ha de reconocer en el enunciador una falta de adhesión a su comportamiento lingüístico. ${ }^{5}$

La ironía del autor textual puede desembocar en la parodia y para ello es preciso que el lector esté vinculando constantemente el objeto paródico a la norma del objeto parodiado. ${ }^{6}$

5 Cf. Frye, 1957: 40; Lozano, Peña-Marín y Abril, 1982: 160.

6 Cf. Segre, 1985: 137; Genette, 19896. 


\subsubsection{Los títulos en el discurso narrativo infantil literario}

El título de las obras literarias es, según Pratt (1977: 61), el equivalente funcional del abstract y obedece a la estructura profunda del texto. En la narrativa de nuestros días, en la que el comentario explícito del autor no está de moda, el título adquiere gran importancia por ser la única manifestación explícita de la voz del autor (cf. Booth, 1974: 198).

Es de rigor matizar que no siempre el productor del título es el propio autor. Existe, sin duda, cierta responsabilidad del editor en este aspecto (Genette, 1987: 71). A pesar de todo, preferimos conferir la paternidad del título de la obra no al editor sino al autor, puesto que, en última instancia, es el autor quien asume jurídica y pragmáticamente la responsabilidad del mismo. En el caso de la narrativa infantil, es verdad que los diseños de las colecciones obligan a cumplir ciertas condiciones tanto en el desarrollo del discurso como en lo que concierne a los elementos paratextuales. Aunque el autor sea fiel irremediablemente a las consignas propuestas por el editor, es él quien firma la obra y a él le corresponde, en definitiva, el consentimiento último dentro de unas premisas con las que parece estar de acuerdo.

El título funciona como un elemento fronterizo entre texto y paratexto por la noción de accesoriedad que acompaña a este último y que es discutible en lo que respecta al título. Por otra parte, estamos de acuerdo con Genette (1987: 72) en que el receptor del título no son sólo los lectores sino también los compradores - que no necesariamente coinciden con los lectores-, los editores, los críticos, etc. De tal modo que el título funciona como carta de presentación y primer puente entre la obra y su público (Martínez Arnaldos, 2003). En lo que concierne a la narrativa infantil, hemos señalado que el discurso está sujeto a más mediadores y más condicionantes desde el punto de vista pragmático que el discurso narrativo literario dirigido a los adultos. En este caso, pues, el título adquiere dimensiones que no se contemplan en la literatura para adultos. Además de designar, seducir y persuadir (Genette, 1987: 73-74), el título funciona como una clave interpretativa que genera ciertas expectativas que el receptor confronta en el desarrollo del discurso (Eco, 1983: 10).

En lo que concierne a la narrativa infantil, Lluch (1998: 86-89) menciona la presencia de títulos basados en el nombre únicamente o en el 
nombre y en una frase explicativa que añade información sobre el mismo (Matilda, Jordi Túrmix, aprenent de pirata), la abundancia de títulos genéricos (La abuela) o de títulos compuestos por frases comunes en la comunicación entre padres e hijos (Ahora si que la he hecho buena). Pocas veces los títulos temáticos ${ }^{7}$ poseen un valor metafórico y los de carácter remático no son muy comunes en el campo de la narrativa infantil.

Així doncs, la literatura per a infants utilitzà majoritàriament els títols construits a partir del tema o del protagonista central de l'obra, que esdevenen una clau interpretativa del text, una informació important sobre com enfocarne la lectura (Lluch, 1998: 89).

Lluch, fiel a las propuestas de Genette (1987), no contempla explícitamente la existencia del autor textual, de tal modo que el título es observado únicamente desde la perspectiva paratextual. Estimamos, sin embargo, que el título es uno de los elementos desde los que se infiere la presencia del autor textual definido como estrategia interpretativa. Es necesario establecer, antes de adentrarnos en el análisis de los diferentes títulos, cómo en el discurso narrativo literario infantil hay que contar con el diseño de la cubieta compuesta siempre por ilustraciones que fundamentan la estrategia interpretativa llevada a cabo por el lector en la recepción del título. Así, las diferentes reseñas que versan sobre estas obras o los catálogos de las diferentes colecciones (Barco de Vapor, Los piratas, etc.) adjuntan al comentario sobre la obra la fotografía de la cubierta ilustrada. Es decir, la ilustración de la cubierta desempeña, a través de un código diferente, la función descriptiva, connotativa y persuasiva que Genette (1987: 84-89) reclama para el título.

Como se ha señalado anteriormente, los títulos temáticos dominan el panorama de la narrativa infantil. La norma habitual no es la presencia de un solo nombre, como Matilda. Lo más frecuente es que en los casos en los que aparece el nombre del protagonista, este se haga acompañar de un sintagma nominal que aporte mayor información —Munia y el cocolilo

7 Utilizamos la clasificación de Genette (1987: 77-85), quien distingue, aplicando criterios formales, entre títulos temáticos — títulos que versan sobre el contenido de la obra—, títulos remáticos — aquellos que aluden a la forma del discurso literario- y mixtos — los constituidos por elementos temáticos y remáticos conjuntamente-. Dentro de los primeros diferencia los propiamente temáticos de otras clases entre las que incluye los títulos que él denomina metonímicos, metafóricos e irónicos. 
naranja, Munia y la luna, La casa de Maisy, Danny, campeón del mundo, Charlie y la fábrica de chocolate, El pequeño Nicolás, Fray Perico y su borrico, La estupenda mamá de Roberta, etc.-, o bien forme parte de una oración - Te quiero, Valero, Oliver Button es un nena, iJulieta, estáte quieta!, Nana Bunilda come pesadillas-. En el caso de que el nombre aparezca aisladamente en la composición del título, este sugiere desde su vertiente fonética más de lo que significa en el aspecto conceptual: Momo, Veva, o, como ocurre en Elvis Karlsson, el nombre connota más de lo que denota:

En el salón, sobre el tocadiscos, hay una fotografía de un cantante. Tiene el pelo fuerte y negro cayendo en bucles. Mamá tiene muchos discos de él y los pone muchas veces. Uno no tiene ni idea de lo que canta, porque canta en inglés, pero lo hace muy fuerte. Algunas veces mamá hasta baila con su música. Cuando está contenta y recuerda otros tiempos, antes de casarse. Cuando él era el «ídolo» al que ella admiraba.

El ídolo se llama Elvis, y por esa razón él también se llama Elvis, para que se pareciera al auténtico Elvis de la fotografía. Pero no resultó así. Su pelo es castaño y tieso como un cepillo. Además tiene la voz ronca y no canta nunca. O sea, que es lógico que mamá tenga preocupaciones (Gripe, Elvis Karlsson: 24).

Todos los títulos que acabamos de mencionar hacen referencia al nombre de un niño o niña o de un animal que realiza las veces de representante de la infancia. De este modo nos encontramos con diminutivos - Charlie, Julieta, Danny —, hipocorísticos — Veva - o nombres que por sus acompañantes sintagmáticos llevan al lector a deducir un contexto infantil —La estupenda mamá de Roberta, El pequeño Nicolás, Oliver Button es un nena-. En estos ejemplos el título alude a la presencia de un protagonista infantil con el que el lector, reclamado por el autor textual, se puede identificar fácilmente.

A partir de los años setenta, comienzan a aparecer en las narraciones literarias infantiles títulos que hacen referencia a frases que se asocian con el mundo de la infancia, frases que, por otra parte, aportan una gran dosis de complicidad con el receptor infantil y que, de alguna forma, implican también a los adultos que realizan la función de mediadores: ;Adiós, pequeño!, ;Huy, qué miedo!, iiiPapááá!!!, jPapá!, Esto que ves es el mar, Ahora no, Fernando, Oliver Button es un nena, No nos podemos dormir, iJulieta, estáte quieta!, No sé, Yo las quería, Porque te quiero. Estos títulos son frases que el niño está muy acostumbrado a oír y que, en la mayoría de las ocasiones, son pronunciadas por adultos muy cercanos al niño - Ahora no, Fernan- 
do, iJulieta, estáte quieta! - o bien se trata de imprecaciones que vinculan al adulto — iHuy, qué miedo!, iilPapááá!!!, ;Papá!, No nos podemos dormir, No sé, Yo las quería-. La voz del adulto y la del niño se oyen desde el título de la obra y generan en el receptor unas expectativas que se desarrollan en líneas muy concretas. ¿A qué obedecen estos títulos? Esta sería la pregunta que cualquier estudioso se puede formular al comprobar que paulatinamente van siendo abandonados los títulos temáticos tradicionales, cercanos al cuento popular y, en algunos casos, prolépticos - El bosque de piedra, El hombrecito vestido de gris, La reina calva, Años dificiles, La rebelión de las lavanderas, Sapo y Sepo, inseparables, Fray Perico y su borrico, El pequeño vampiro, La estupenda mamá de Roberta.

Del mismo modo, es destacable la presencia en el corpus seleccionado de títulos que resultan provocadores y que, en cierta manera, suponen un desafío del mundo infantil hacia el mundo de los adultos que se erige como mantenedor de las normas establecidas. Cuentos en verso para niños perversos —una traducción muy acertada—, El libro apestoso, ;Qué asco de bichos!, Un culete independiente, Diecisiete cuentos y dos pingüinos y Hasta (casi) cien bichos pueden servir de ejemplos de lo anteriormente afirmado.

El autor textual que descubren estos títulos se está haciendo eco de una sociedad que nace a partir de los años setenta, en la que se gestan los valores propios de las sociedades actuales. En el campo de la literatura infantil, especialmente en el de la narrativa, se tiende a reaccionar contra las corrientes realistas que habían predominado en las artes desde la segunda guerra mundial, cuestionando así los valores pedagógicos que había exhibido la narrativa infantil hasta entonces. ${ }^{8}$

La complejidad de los conflictos, los cambios de perspectivas, la ambigüedad de los sentimientos se reflejarán en las narraciones dirigidas al mundo infantil. No está de moda ya el niño perfecto propio de otras épocas al que se refiere Jan (1985: 108):

En otras palabras, los niños de los cuentos de Père Castor son niños pretexto para la demostración pedagógica. Sólo la pedagogía ha cambiado. Ahora, en lugar de ser dóciles, razonables y caritativos, son activos, despiertos y generosos, pero no son dramáticos y, cosa más grave, incluso no son divertidos, han de tener esa ambigüedad que les hace imperfectos.

8 Cf. Jan, 1985: 36; Sáiz Ripoll, 1993; Colomer, 1999: 108. 
El nuevo receptor y, por ende, el nuevo autor textual van a reflejar esa nueva concepción de la narración literaria dedicada al niño. Desde el título, el autor textual a partir de los setenta expresa esa confianza en una sociedad que ha recibido la denominación de posindustrial, una sociedad en la que coexisten discursos distintos que anulan la existencia de un modelo externo de comportamiento bien delimitado. La ideología que se esconde en los títulos que acabamos de mencionar, sobre todo en los de carácter provocador, tiende a reivindicar el derecho individual a la libertad en detrimento del ciego sometimiento a las convenciones sociales jerarquizadas y a establecer, a través de la implicación del adulto, unas relaciones de complicidad con el mismo (cf. Colomer, 1999: 109).

En el entorno social que acabamos de describir aparece un autor textual que desde los títulos mencionados se acerca a una nueva perspectiva de la narrativa infantil, con un receptor al que se le ofrece toda clase de temas partiendo de que el niño de la sociedad actual sufre conflictos y angustias que desea ver reflejadas en los libros que a él se dirigen. La infancia ya no se contempla como un estado idílico desde la perspectiva adulta sino que muestra sus intereses, sus problemas, su derecho a la libertad y al placer, al ocio, en detrimento de una narrativa que hasta ahora se había visto invadida por la función educativa.

No le gustaban los libros en que, con malhumor y de forma avinagrada, se contaban acontecimientos totalmente corrientes de la vida totalmente corriente de personas totalmente corrientes. De eso había ya bastante en la realidad y, ¿por qué había que leer además sobre ello? Por otra parte, le daba cien patadas cuando se daba cuenta de que lo que querían era convencer de algo. Y en esa clase de libros, más o menos claramente, siempre lo querían convencer a uno de algo (Ende, La historia interminable, 1982: 27-28).

Destacable, en esta misma línea, es la presencia, en los últimos años, de títulos intertextuales que aluden a hipotextos con los que se pretende jugar y trabajar de esta forma lo que se ha dado en llamar la fantasía moderna (Colomer, 1999: 130-132). Una vez más nos encontramos ante una de las vías por las que ha transcurrido la renovación de la literatura infantil en la última década. Se camina hacia el juego metaliterario incardinado en una sociedad en la que predomina la posmodernidad, como contemplación de un individuo en permanente construcción. 
Desde los títulos se observa esta concepción del autor textual que confía en la competencia literaria del receptor y lo introduce en un mundo en el que todo se relativiza y subvierte. Títulos como Perro y gato, Cuando los borregos no pueden dormir, Por el hilo se saca el ovillo, Quisicosas, El lobo feroz, Pelotieso y Ricitos de Oro, Los osos de Ni-se-sabe, Libro de las M'Alicias, etc. constituyen una muestra de este tipo de autor textual que avanza en la cubierta cuál es el sistema del que parte. Es significativo que sea el álbum la modalidad que se adentre mayoritariamente en este campo, coincidiendo con un ámbito de mayor experimentalidad, tal como hemos señalado en el capítulo anterior. La transtextualidad suele ir acompañada —no siempre lo hace — de la desmitificación y de la vía humorística como procedimientos por los cuales el receptor se distancia del mensaje.

Así el Libro de las M'Alicias anuncia desde el título compuesto por un calambur el proceso de deconstrucción al que se somete la obra de Alicia en el pais de las maravillas desde la imagen y desde el texto con una intención irónica que desemboca en una crítica social.

En definitiva, los títulos de la narrativa infantil de nuestros días manifiestan el cambio que se ha producido en el último cuarto del siglo XX: desde los realistas e incluso prolépticos, pasando por los que suponen una mayor implicación del receptor, hasta llegar a la experimentalidad metaliteraria que caracteriza parte de la narrativa infantil de nuestros días.

\subsubsection{Los intertítulos}

El intertítulo, al contrario que el título, no es accesible, en toda su significación, para el público en general sino para el lector comprometido con el texto y, por otra parte, no es indispensable su presencia en el texto (cf. Genette, 1987: 271).

El autor textual se manifiesta del mismo modo en los títulos de los capítulos, como ya se ha mencionado. Aclaremos que estamos tratando de la configuración de capítulos no dependiente del narrador sino del autor. Necesitamos distinguir entre los títulos que forman parte del ámbito del narrador y los que pertenecen al autor textual. En principio, entendemos que los encabezamientos de los capítulos que desempeñan la función de resumen y que no se encuentran inmersos en el discurso son responsabilidad del autor textual. No corresponden al mismo, sin embargo, aquellos que, 
aun funcionando como síntesis del capítulo que introducen, estructuran el discurso desde dentro ubicándose de esta forma en el ámbito del narrador. Así por ejemplo, si nos acercamos a la obra Me importa un comino el rey Pepino, de Nöstlinger, o a Querida abuela, tu Susi, de la misma autora, distinguiremos con cierta claridad cuáles son los títulos que pertenecen a la esfera del narrador. Tanto en uno como en otro libro la estructuración del discurso es responsabilidad del narrador. Así en Me importa un comino el rey Pepino, Wolfgang, el niño que cuenta o, mejor dicho, escribe la historia, va narrando en primera persona la historia que ha presenciado y lo hace como si fuera una redacción de clase, siguiendo los consejos del profesor de lengua. De esta forma justifica Wolfgang la fragmentación de la narración:

\author{
Prólogo \\ Mi abuelo ha dicho que uno de nosotros tiene que escribir la historia. Y \\ en eso, el abuelo tiene razón. \\ Martina dijo que lo haría ella, pero lo único que ha hecho hasta ahora \\ ha sido comprar un montón de papel rosa y una cinta verde para la máquina \\ de escribir. Dice que no ha empezado a escribir todavía porque la estructura \\ de la historia es muy difícil. La dificultad de una historia radica en la estruc- \\ tura, ha dicho su profesor de Lengua. \\ A mí me tiene sin cuidado la estructura. Y como ahora tengo un pie \\ enyesado y no puedo ir a nadar, pues la escribo. \\ CAPÍTULO PRIMERO o N. ${ }^{\circ} 1$. \\ SEGÚN LA ESTRUCTURA DEL PROFESOR DE LENGUA \\ Describo quiénes somos. \\ Lo que apareció de repente en la cocina. \\ El redactor jefe no quiere saber nada. \\ Las cámaras de fotos tampoco quieren a pesar de que hay cinco. (Nös- \\ tlinger, Me importa un comino el rey Pepino: 10-11). \\ ÉSTE ES EL ÚLTIMO CAPÍTULO. \\ EL DECIMOQUINTO \\ Está bien que se termine ya esta historia, porque mañana me quitan el \\ yeso y ya no tendría tiempo para escribir. En este último capítulo cuento cómo \\ Nik nos saca del apuro. (Nöstlinger, Me importa un comino el rey Pepino: 114).
}

A juzgar por el ejemplo propuesto, los títulos de los capítulos corresponden en esta narración a la voz del narrador justificada desde el prólogo. De la misma forma, en Querida abuela, tu Susi los encabezamientos de las cartas que Susi escribe a su abuela sirven como encabezados a los diferentes fragmentos de la narración. En estos intertítulos, como señala Genette (1987: 278), el héroe-narrador se convierte no sólo en instancia narrativa sino en instancia literaria, en autor responsable de la constitución del texto. 
Los intertítulos que pertenecen al autor textual suelen estar constituidos por una frase que resume el contenido del capítulo. Dejamos de lado los títulos que, dentro de una misma obra, corresponden a diferentes narraciones puesto que consideramos que cada cuento constituye una obra independiente. Así por ejemplo, los libros de Sapo y Sepo están compuestos por una serie de aventuras que corren los dos personajes, cada una con un principio y un final independiente de las demás: La lista, El sombrero, El sapo de las Tinieblas, El invierno, etc. Nos referimos en este momento a los epígrafes de los capítulos que componen una obra. Estos no aparecen en los álbumes infantiles ni en la narrativa dirigida a niños a partir de 5 años. Están presentes, sin embargo, en las obras que requieren la presencia de un destinatario mayor de 8 años, es decir, en lo que hemos dado en llamar novela para niños. En este tipo de creación se parte de la idea de que el niño puede acercarse a historias más extensas que las que implica el álbum o el cuento, sin llegar a la estructura propia de la novela juvenil. En la novela para niños el lector se aproxima al concepto de capítulo dentro de las andanzas de un personaje que inicia un camino fragmentado en diferentes secuencias. Cada capítulo suele constituir una unidad, relacionada con los demás capítulos, con un inicio y un final propios dentro del argumento general. No es inusual la ausencia en las unidades de epígrafes verbales, que son sustituidos por números que ordenan en el tiempo y en el espacio la sucesión de las unidades narrativas. Así ocurre en iQue me parta un rayo!, de Barrena; La reina calva, de Company; El ladrón de sombras, de Cela; Fantasmas de día, de Baquedano, entre otras obras. Lo más común es, sin embargo, la presencia de intertítulos que marcan concisamente, como corresponde a la narrativa del siglo XX, a través de un sintagma u oración simple, el contenido de la unidad. De esta manera, rezan epígrafes como «La hoja de begonia» $\mathrm{o}$ "El mudito loco» en Las manos en el agua, de Murciano; «La cosa en la ventana» o «Sabiduría de padres» en El pequeño vampiro, de Sommer-Bondenburg; «Hombre al cielo» o "Paréntesis» en El planeta de los árboles de Navidad, de Rodari; «El primer día de colegio» o "La moda de los huevos duros» en Ramona empieza el curso, de Cleary; «El verde silencio de las estatuas de piedra» o «El viejo guerrero» en $E l$ bosque de piedra, de Alonso; «Adela» o "La redacción» en Mi hermano mayor, de Company, entre otras obras.

En realidad, se trata de destacar el motivo principal del capítulo, lo que correspondería, mutatis mutandis, al tópico. De esta forma, se generan 
unas expectativas en el receptor y se establecen unas claves de interpretación del texto. Estos epígrafes no son responsabilidad del narrador como en los casos anteriormente comentados y tampoco se consideran parte del peritexto editorial. En ellos se vuelve a reflejar el autor textual. En primer lugar, como se puede comprobar en los ejemplos aducidos, la estructura más común es la del sintagma nominal que, en varios de los casos, hace referencia a un mundo fácilmente identificable por el receptor, ya que se trata de conceptos vinculados al niño del siglo XX. Además el autor textual refleja una preocupación por interesar al receptor con lemas atractivos que facilitan la comprensión del discurso, tal como corresponde a un lector que va adquiriendo una competencia literaria progresiva. No hay que olvidar además que la fragmentación de la narración en capítulos se realiza asimismo en aras de un destinatario que todavía necesita poder establecer pausas en la recepción y una ayuda para organizar el relato en el tiempo.

No siempre los intertítulos observan la forma que acabamos de comentar. Encontramos en el corpus seleccionado un tipo de epígrafe no demasiado común que obedece a un autor textual digno de comentario. De este modo, en La abuela, de Härtling, cada capítulo es introducido por una frase que resume la situación principal de la que parte el discurso: «De cómo Karli fue a parar a casa de la abuela", "Cuando la abuela se pone a contar cosas», "La abuela discute con el televisor», «La abuela cae enferma», "Karli cumple los diez». En algunas ocasiones, intertítulos como estos recuerdan los encabezados de la novela picaresca y, cómo no, del Quijote, de carácter cómico y popular, incluso irónico, con ese afán de señalar detalladamente el contenido del capítulo no en la voz del narrador sino en la de la enunciación del autor. Lo que es destacable en este tipo de títulos, de la misma forma que en El pequeño Nicolás, de Goscinny, donde aparecen epígrafes como «Un recuerdo que nos gustará» o "Ensayamos para el ministro", es la presencia de la focalización propia de la narración ya en estos subtítulos. Realmente, desde el punto de vista formal, estos enunciados, aun funcionando como síntesis del contenido de los capítulos, observan la misma voz y la misma perspectiva de la narración. No obedecen a ninguna estructura previamente justificada sino que el autor textual adopta la voz del narrador utilizando un recurso, el de la ironía, en la línea de la narración. Una vez más, el intertítulo se considera una estrategia de acercamiento al texto presidido por la misma perspectiva que se utiliza en el transcurso de la narración. 
Un recuerdo que nos gustará

Esta mañana llegamos todos a la escuela muy contentos, porque van a sacar una foto de la clase, que será para nosotros un recuerdo que nos gustará toda la vida, como ha dicho la maestra. También nos dijo que viniéramos muy limpios y bien peinados.

Cuando yo entré en el patio de recreo llevaba la cabeza bien llena de brillantina. Todos los compañeros estaban ya allí y la maestra riñéndole a Godofredo, que había venido vestido de marciano. Godofredo tiene un papá muy rico que le compra todos los juguetes que se le antojan. Godofredo le decía a la maestra que quería fotografiarse de marciano, y que si no se iría (El pequeño Nicolás: 11).

Cómo no recordar, al hilo del ejemplo anterior, el tono de los epígrafes que encabezan cada capítulo de Manolito Gafotas, de Lindo:

\footnotetext{
El último mono

No sabrán quién es Manuel, ni Manolo, ni Manuel García Moreno, ni el nuevo Joselito, pero todo el mundo te dará pelos y también señales de Manolito, más conocido a este lado del río Manzanares como Gafotas, más conocido en su propia casa como "Ya ves tú quién fue a hablar: El Último Mono» (Manolito Gafotas: 12).
}

En definitiva, sean los epígrafes de los capítulos como fueren, la imagen del autor textual que se infiere de los mismos es la de un emisor que entiende que las expectativas generadas en el receptor hay que cubrirlas y que este necesita ciertas claves interpretativas para acercarse al discurso. A través de los epígrafes descubrimos en el discurso narrativo infantil a un autor textual preocupado por atraer la atención del receptor y por establecer una fragmentación que facilite la recepción de la obra por parte de un sujeto que está elaborando su competencia literaria. ¿Desconfianza en las capacidades del receptor, quizá?

Hay que mencionar también la presencia de índices, bien al principio, bien al final de la obra, que contribuyen a ofrecer una idea del contenido del transcurso de la narración. Estos índices orientan al receptor infantil, por una parte, y, por otra, suponen una guía de contenido que el adulto puede consultar al acercarse a la obra. Los índices suelen ser muy útiles a los maestros en el caso de que la novela permita la lectura aislada e independiente de cada uno de los capítulos, como ocurre en El pequeño Nicolás, de Goscinny, o en Fray Perico y su borrico, de Muñoz Martín.

Todo lo que hemos expuesto hasta ahora es válido en lo que concierne al discurso literario infantil que no corresponde al álbum. Así, en los 
álbumes de una extensión considerable los intertítulos desaperecen, aunque no lo haga el concepto de capítulo. Por ejemplo, el Libro de las M'Alicias o La carta de la señora González optan por la numeración en cada uno de los fragmentos capitulares de la historia. Indudablemente, en este tipo de obra ya no es tan necesario que desde los intertítulos se establezcan las claves de interpretación, puesto que la imagen contribuye ex aequo a la construcción de los significados; por tanto, interpreta el texto.

En el caso de La carta de la señora González, los números que introducen cada capítulo forman parte de la simbología de la que se nutre toda la obra (Carranza, 2002).

\subsubsection{Los prólogos y dedicatorias}

Ya en el capítulo anterior se mencionó la existencia de prólogos que venían firmados por el autor pero que obedecían al diseño de la colección; por lo tanto, eran impuestos por la editorial y todos ellos constituían una animación a la lectura en abstracto sin llegar a aplicarse directamente al discurso que introducía. Comprobamos entonces que el receptor de los mismos no era otro que el adulto mediador. Nos interesan aquí los prólogos firmados por el autor, los denominados por Genette (1987: 169) préfaces auctoriales, los que, de algún modo, contribuyen a forjar la imagen del autor textual. No son estos elementos muy comunes en la narrativa infantil pero cuando aparecen son altamente significativos.

Así, Mendo (El vendedor de agujeros: 3 ) inicia su obra con un prólogo en el que expone cuál es el origen de su obra:

El vendedor de agujeros es una pequeña novela de aventuras. La idea de escribirla me surgió a partir de una noche de esas que estás con los amigos charlando y diciendo tonterías (y creo que muchas cosas interesantes surgen de ese tipo de tonterías). Entre las muchas que se dijeron a mí se me ocurrió que podría estar muy bien que en vez de utilizar taladradoras, uno pudiese ir a la ferretería y comprar «agujeros» del ancho y la profundidad deseada, como actualmente se va a la papelería a comprar letras adhesivas. En fin que sería divertido que hubiese agujeros-pegatina.

A partir de esa bobada surgió este libro que tienes en las manos [...].

En este prólogo — no demasiado habitual— se descubre la imagen de un autor textual que trata de justificar ante el receptor la trama de la obra que ha escrito. Asimismo adivinamos una necesidad de explicar que supe- 
ra los límites de lo exigido. Expresiones como pequeña novela o esa boba$d a$ parecen esconder una ausencia de fe en lo que se ha escrito. Esta actitud, no tan extraña como desearíamos, ${ }^{9}$ nada ha favorecido el desarrollo de la narrativa infantil. A no ser que tales expresiones obedezcan a lo que la retórica clásica denominaba excusatio propter infirmitatem, que correspondía al tópico de la falsa modestia.

Sin corresponder al prólogo exactamente e identificándose de algún modo con la antigua práctica del prefacio integrado en el discurso, el autor textual a veces se refleja en el propio discurso literario acercándose a lo que Genette (1987: 168) denomina prólogo auctorial ficticio — préface auctoriale fictive-, a través de comentarios como el que sigue:

No sé si el cuento que ha venido a entristecerme es para niños; puede ser un cuento de niños para padres o para que un padre y su hijo lo escuchen cogidos de la mano. Empieza así:

Hace muchos, muchos años, en la antigua China, en una ciudad de papel y barro, blanca de caolín, entre plantas de arroz y té, un niño igual que todos los niños volaba su cometa (Farias, "La larga siesta de papá», en Algunos niños, tres perros y más cosas: 11).

No es la voz del narrador la que escuchamos aquí sino la del autor textual, quien, en primera persona, muestra su confusión al configurar la identidad del destinatario de su cuento. Con esta introducción el autor textual genera en el receptor ciertas expectativas y claves de interpretación del cuento por parte del destinatario. Una vez más, se podría interpretar esta intervención del autor textual en la línea de la justificación de lo que va a continuación.

Härtling, en el prólogo de Ben quiere a Anna, se expresa en forma de una declaración de intenciones, en el marco de lo que Genette (1987: 213) denomina prólogos esquivos:

9 No es este el lugar para exponer cuáles son las premisas de las que el autor real parte en el momento de acercarse a la narrativa infantil. Sin embargo, podemos apuntar que no es inusual el caso de aquellos que intentan, a causa de ciertos "complejos», alejarse de la etiqueta de narrativa infantil atribuyendo a las editoriales la responsabilidad de haber imbricado sus obras en colecciones infantiles o juveniles (cf. a este respecto Argüeso, 2000: 44-51). Todavía en nuestros tiempos debemos luchar contra esta falta de dignidad que le atribuyen a la narrativa infantil, incluso personas que se dedican a ella. Convendría a este respecto analizar todo lo que concierne al epitexto editorial definido por Genette (1987: 316). 
Esto no es ningún prólogo. Sólo quiero explicar, en pocas frases, por qué cuento la historia de Benjamin Körbel y Anna Mitschek. A veces los adultos les dicen a los niños: vosotros no tenéis edad para saber lo que es el amor. Hay que ser mayor para saberlo.

Eso significa que han olvidado muchas cosas, no tienen ganas de hablar con vosotros o se hacen los tontos.

Yo recuerdo perfectamente cómo me enamoré por primera vez a los siete años. Ella se llamaba Úrsula. No es la Anna de este libro. Pero al hablar de Anna pienso también en Úrsula. Ben quiso mucho a Anna. Y Anna a Ben (Ben quiere a Anna: 5).

Se inserta de esta manera el autor textual en la referencia a un nuevo receptor que exige la ruptura del tabú social vinculado a la existencia del amor y de la sexualidad infantil y juvenil. ${ }^{10}$ Un nuevo receptor, una nueva narrativa y un nuevo autor textual.

Similar, aunque no igual, es el contenido del prólogo de Años dificiles, de Farias. En esta narración el prólogo no es firmado por el autor pero hay un momento del mismo en el que se puede adivinar la presencia del autor textual:

Así que Juan Farias tomó la decisión de contar a los niños que hay guerras y muerte y lo que pasa en la guerra y lo que sufren los que la hacen y los que se resisten a hacerla y hasta los que no tienen nada que ver con ella (Farias, Años dificiles: 3 ).

Se trata, en definitiva, de justificar la presencia de temas que hasta ahora habían sido vetados para la infancia.

A modo de prólogo, constituyendo asimismo una clave interpretativa dirigida al receptor, es necesario comentar una costumbre que se ha extendido en los últimos años del siglo y es la introducción de intertextos en lugar del prólogo y de la dedicatoria, es decir, se incluyen textos de otros autores que funcionan a modo de guía-resumen del sentido de la obra. Valgan como ejemplos los textos que introducen Años difíciles, de Farias; Las manos en el agua, de Murciano; y El bosque de piedra, de Alonso:

La guerra que vendrá no es la primera. Hubo otras guerras. B. Brecht (Años difíciles: 5$)$.

Pájaro del agua, / ¿qué cantas, qué encantas? Juan Ramón Jiménez (Las manos en el agua: 6).

10 Cf. Elizagaray, 1997; Colomer, 1998. 
Sistema, poeta, sistema. / Empieza por contar las piedras, / luego contarás las estrellas (El bosque de piedra: 9).

Existen asimismo prólogos que consignan el orden de lectura de lo que viene a continuación. Así, los libros que forman parte de la colección de Elige tu propia aventura presentan un prólogo en el que se explica cómo se ha de leer la narración que figura a continuación:

\footnotetext{
¿Lee esto primero!

La mayoría de los libros se refieren a otras personas. Éste, en cambio, trata sobre ti y sobre los fantasmas que habitan la Torre de Londres.

Lo que te ocurra en esta historia dependerá de las decisiones que tomes.

No leas el libro seguido, desde el principio hasta el fin. En lugar de ello, empieza en la página 1 y lee hasta que llegues a la primera elección. Decide entonces qué opción quieres tomar. Luego, busca la página señalada y verás lo que ocurre.

Cuando llegues al final de la historia, vuelve a empezar y toma otra decisión. Cada elección te llevará a una nueva aventura.

¿Estás preparado para explorar la Torre de Londres? Entonces pasa a la página $1 . .$. y ¡ buena suerte! (La torre de Londres: VII).
}

Aunque adquieren diversas formas, los prólogos en narrativa infantil desempeñan dentro del discurso la función de captar la benevolencia del receptor.

¿Por qué son escasos los prólogos en el discurso narrativo infantil si sus funciones principales son las de conseguir lectores y proponer cómo se ha de leer el discurso? Parecería, por tanto, una consecuencia previsible que el discurso narrativo literario infantil contara con el prólogo como un elemento inexcusable. Sin embargo, no es así. La escasez de este elemento puede justificarse por el hecho de que el autor textual se preocupa en exceso por llegar al mediador adulto, que, en definitiva, es el que va a recomendar la obra al receptor infantil. A este mediador se dirigen, por otra parte, los textos de las contracubiertas, lo cual, en cierta forma, anula la función del prólogo tradicional.

Otra cuestión es, como ocurre, por ejemplo, en El grito de la grulla, de Alonso, la presencia de prólogos que justifican desde el punto de vista contextual el relato. Se trata de prólogos impensables en la literatura para adultos, que cumplen, sin embargo, una función de guía en la intrepretación posterior: 
Entre 1939 y 1945, hubo una terrible guerra en la que estuvieron implicados muchos países. Se la recuerda como la segunda guerra mundial [...]. La historia que os voy a contar se desarrolla allí, en Nagasaki, en aquella fecha ( $E l$ grito de la grulla: 7-8).

En lo que respecta a los álbumes, el prólogo dependiente del autor textual es casi inexistente puesto que no se hace necesaria la guía de interpretación que supone el elemento textual del que estamos tratando. La imagen suple esta función, como se puede comprobar en obras como Mamá fue pequeña antes de ser mayor, La carta de la señora González, Los tres erizos, por citar algunos ejemplos.

En cuanto a las dedicatorias, podemos señalar que es común que las narraciones analizadas presenten dedicatorias privadas (Genette, 1987: 123); generalmente, se trata de dedicatorias dirigidas a niños que mantienen una relación con el autor real —hijos, sobrinos, etc.- - No son extrañas las dedicatorias que combinan un destinatario concreto con uno de extensión general que se identifica con el lector que paulatinamente se va construyendo como referente implícito:

Este libro es para Burghardt Bodenburg, quien, con sus blandos dientes, nunca podría llegar a ser un vampiro, y para Ada-Verena Gass, que domina magistralmente la mirada del vampiro, y, además, para Katja, que sabe gritar «iliiih, un vampiro!» de forma tan admirable, ¡y para todos aquellos a los que les gusta tanto como a mí leer historias de vampiros! Sommer-Bodenburg ( $E l$ pequeño vampiro: 9).

La función de la dedicatoria, sea como fuere, es destacar una relación entre el actor y el destinatario de ella:

Le dédicataire est toujours de quelque manière responsable de l'oeuvre qui lui est dédiée, et à laquelle il apporte, volens nolens, un peu de son soutien, et donc de sa participation. Ce peu n'est pas rien: faut-il rappeler encore que le garant, en latin, se disait auctor? (Genette, 1987: 127).

Las palabras de Genette subrayan la filiación que se establece entre el autor y el destinatario de la dedicatoria de la obra. De tal modo que dedicatorias como la que aparece en la obra de Obiols y Calatayud titulada Libro de las M'Alicias - A Lewis Carroll- se convierten en una de las claves para la interpretación del texto que, en el caso que nos ocupa, se anuncia ya desde el título. 
De la misma forma, se establecen pautas para la interpretación de la fuente del discurso en dedicatorias como la de El pequeño Nicolás — «Para Henri Amouroux, padrino de este Nicolás»—o más explícitamente con referencias al personaje protagonista en Yo las quería - "A nuestros padres Joan y María, Ferrán y Matilde, la de los cabellos color del cobre».

\subsection{El narrador}

Una de las categorías discursivas fundamentales en el análisis del discurso narrativo es, sin duda, el narrador. Los valores de una historia dependen, en principio, de la autoridad de quien la cuenta así como de la forma de contar. En principio nos vamos a centrar en el análisis del narrador como categoría discursiva y, en aras de la claridad expositiva, nos referiremos, en algunos momentos, al narrador como categoría del relato, concretamente en lo que concierne al concepto de perspectiva. De este modo, teniendo en cuenta que la cuestión de la perspectiva es fundamental en el discurso narrativo infantil y que el saber del narrador está condicionado por su relación con la acción, hemos optado por estudiar este punto dentro de lo referente al narrador como categoría discursiva. Por otra parte, la distancia, otra de las categorías modales que distingue Genette (1989: 220), aparecerá en el momento en que tratemos la narración.

El narrador constituye el elemento fundamental del relato. A él se supeditan las demás categorías que componen el mundo narrativo. Tradicionalmente se han relacionado narrador y sabiduría. En principio, la voz narrativa es la voz del autor, la voz «autorizada» de la épica clásica. Con la aparición del espíritu burgués, la posición discursiva del narrador se subjetiviza y resulta desempeñar diferentes funciones. Ya desde Platón, en el caso de la narración homodiegética, se empezó a observar que el «yo» del texto puede remitir a un enunciador que no coincide con el autor (cf. García Landa, 1998: 280-281). Hay que esperar al siglo XX para que esta observación se extienda a la narración heterodiegética. La crítica de la primera mitad de este siglo aún sigue confundiendo en ocasiones los campos del autor y del narrador en la narración heterodiegética. Así, Croce o Vossler (cf. Martínez Bonati, 1972: 154) definían la obra literaria como la expresión de la subjetividad del autor. Las corrientes del formalismo ruso y del estructuralismo reaccionaron contra estas consideraciones reivindi- 
cando para el narrador el eje central del discurso puesto que a él le atribuyen la responsabilidad de organizar y filtrar el material narrativo. Para los narratólogos franceses, el narrador se comporta como un «sabedor» y se define por el grado de conocimiento de la realidad presentada. Este grado dependerá, en algunos casos (Pouillon, 1970: 23; Todorov, 1975: 65), del punto de observación elegido por el narrador, en otros, de la presencia o ausencia de un filtro (Genette, 1989a: 244-245; 1998: 29).

Dentro de la tradición anglo-norteamericana (Lubbock, Friedman, cits. por Garrido Domínguez, 1993: 107), se opta por identificar al narrador con el papel de un callado observador, cuanto más silencioso mejor, de tal forma que parezca que el relato se cuenta a sí mismo.

Por último, las corrientes de inspiración lingüística definen al narrador como hablante o locutor. El enunciado narrativo es un mensaje que requiere un sujeto de la enunciación que no es otro que el narrador (Benveniste, 1966; Bajtin, 1989). Posteriormente las teorías de inspiración pragmática incorporarán a esta definición del discurso la presencia del receptor y del contexto en que el enunciado se produce. La teoría de Benveniste, sin embargo, contempla como posibilidad la existencia de un relato sin narrador.

Ante los intentos expuestos de erradicar al narrador, reaccionaron, en primer lugar, Booth (1974) y después, los narratólogos franceses - Barthes (1966), Todorov (1975), Genette (1989a)—, que consideraron que no es posible una enunciación sin la existencia de un sujeto enunciador, como no lo es la existencia de un relato sin narrador.

Prescindiendo del enfoque por el que queramos optar, el narrador se define como aquella categoría que, dentro del discurso narrativo, asume el papel de sujeto de la enunciación, y, por lo tanto, tiene como función primordial la de contar (cf. Sánchez Rey, 1991: 249).

Cuando nos referimos al narrador, es necesario discernir con Genette (1989a: 241-242) entre el narrador como sujeto de la percepción — ¿quién ve? - y como enunciador — ¿quién habla?- El narrador, en tanto que narrador, tiene una competencia modal respecto de la acción y de sus interlocutores y cuando nos referimos al modo, aludimos asimismo a la distancia y a la perspectiva. Señala García Landa (1998: 291) que el narrador no puede definirse únicamente en cuanto a su hacer sino que, además 
de comunicar su mensaje, se comunica a sí mismo. Por tanto, es necesario definir también su ser, deber, querer, poder y saber. La propuesta del narratólogo francés (1989a y 1998), con algunas precisiones como las señaladas, será la que nos sirva de marco, siempre flexible, para abordar una de las instancias enunciativas fundamentales en el campo que nos ocupa. El narrador es el intermediario entre el autor y el receptor del discurso y en el caso de que no exista un narrador ficticio es el autor textual el que asume directamente la narración. ${ }^{11}$ Paradójicamente, el receptor tiene la impresión de que es el narrador el responsable del discurso, cuando es este el que va siendo construido e identificado por el propio discurso. No olvidemos, además, que el narrador va pergeñando un narratario a su medida, lo cual en el caso del discurso narrativo infantil puede adquirir una importancia decisiva. ${ }^{12}$

Narrador y narratario serán instancias textuales que estudiaremos con la finalidad de establecer unos parámetros que contribuyan a caracterizar la especificidad del discurso narrativo literario infantil. Variados han sido los estudios que han versado sobre la instancia enunciativa del narrador y todos ellos han intentado definir el papel desempeñado por el narrador desde cinco aspectos fundamentales: identidad del narrador — ¿quién es?-, grado de información — ¿cuánto sabe?_, posición desde la que narra — ¿desde dónde narra?_-, momento en el que narra — ¿cuándo narra?-y su implicación — ¿cómo narra?- (Spang, 1993).

\subsubsection{La identidad del narrador}

A pesar de que algunos estudiosos como Tacca (1973: 69) nieguen cualquier identidad al narrador, son varios los enfoques que contribuyen a aquilatar el ser del mismo. La identidad del narrador puede definirse desde su participación o no en la historia, desde su número y desde sus funciones. Estos tres aspectos contribuirán a definir quién es el narrador del discurso. El narrador aporta cierta visión del mundo, ciertas peculiaridades ideológicas o lingüísticas, etc.

11 Cf. Tomashevski, 1982: 278; Friedman, 1972: 125; Booth, 1974: 151; Genette, 1966: 162; Dijk, 1972: 302; Tacca, 1973: 35; y Segre, 1985: 26.

12 Cf. a este respecto Eco, 1987: 88; Greimas y Courtés, 1990: 125; y Lozano, PeñaMarín y Abril, 1982: 42 y 90. 


\subsubsection{La participación en la historia}

El narrador ocupa el nivel extradiegético respecto a su narración y el personaje el nivel intradiegético. Una narración dentro de la narración principal será una narración intradiegética o un relato intradiegético (méta-récit, en la terminología de Genette, o hypo-récit, en Bal). El personaje protagonista de una narración intradiegética ocupa el nivel intradiegético en segundo grado. El narrador de este relato ocupa una posición extradiegética respecto del propio relato, pero su posición respecto del relato principal es intradiegética. Habiendo aclarado estos términos, nos referiremos al narrador en dos sentidos: uno, relativo, respecto a su propia narración; otro, absoluto, respecto a la narración principal.

\section{A) El narrador participante}

El narrador participante se define asimismo como narrador figural, es decir, participa en la historia como protagonista o como figura secundaria. De todos modos, recordamos que el personaje-narrador es intradiegético, así como es extradiegético en lo que respecta a su narración. En principio, pues, todo narrador figural es intradiegético en su vinculación al personaje y extradiegético o intradiegético en su vinculación a la narración.

El narrador como personaje de la historia apenas aparece en las narraciones dirigidas a los más pequeños. Como excepciones, se pueden reseñar los álbumes No sé, de Piérola; Ha sido el pequeño monstruo, de Cooper; y iiiPapááá...!!!! de Cano, obras en las que el narrador se identifica con el protagonista y corresponden a un tipo de narración de corte psicológico:

No sé dónde estuve antes de estar aquí. No sé por qué somos tantos. O tan pocos. No sé quién mueve el sol desde tan alto o dónde se enchufa la luna (No sé: 4-11).

Me gustaba más cuando éramos sólo tres: mamá, papá y yo, y estábamos tranquilos en casa... casi siempre. Pero un día, antes de ir al hospital, mamá me hizo un regalo. Llevaba una etiqueta que decía: este pequeño monstruo quiere ser tu amigo. Y lo fue. Me quería mucho... (Ha sido el pequeño monstruo: $3-5)$.

Todas las noches, cuando estoy a punto de caer de la tabla de un barco pirata y ser devorado por los tiburones... Cuando el Séptimo de Caballería nos tiene rodeados a mí y a toda mi tribu... Cuando una legión de momias me persigue pirámide arriba y no tengo escapatoria... (iiiPapááá...!!!: 5-11). 
El panorama se modifica, sin embargo, cuando el receptor se acerca a la edad de 6 años. En este tipo de narraciones no es infrecuente la presencia de narradores figurales que se identifican con la primera persona fundamentalmente, unas veces protagonista, otras veces como figura secundaria. Es el caso, por ejemplo, de los narradores de obras como No nos podemos dormir, de Stevenson; "Escalofríos» en Días con Sapo y Sepo, de Lobel; Querida abuela, tu Susi, de Nöstlinger; El pequeño Nicolás, de Goscinny, o Las brujas, de Dahl, por citar algunos ejemplos.

A mí una vez me pasó lo mismo. Fue hace muchos años. Tendría yo vuestra edad. No hacía más que dar vueltas en la cama. Conté ovejas. Y como si nada. Así que me levanté, me vestí y salí a la calle. Quizá caminar me fuera bien (No nos podemos dormir: 2-4).

Sapo hizó té y sirvió dos tazas. Se sentó y empezó a contar un cuento: - Una vez, cuando yo era pequeño, mi madre, mi padre y yo salimos a merendar al campo. Al volver a casa nos perdimos. Mi madre se apuró mucho ( Escalofríos», en Días con Sapo y Sepo: 34).

Yo mismo tuve dos encuentros distintos con brujas antes de cumplir los ocho años. Del primero escapé sin daño, pero en la segunda ocasión no tuve tanta suerte. Me sucedieron cosas que seguramente te harán gritar cuando las leas. No puedo remediarlo. Hay que contar la verdad. El hecho de que aún esté aquí y pueda contártelo (por muy raro que sea mi aspecto) se debe enteramente a mi maravillosa abuela (Las brujas: 16).

Cuando me morí, no lo entendí muy bien. Quiero decir que no supe cómo había sido. Ni siquiera sabía que estaba muerto, y cuando oí decirlo a los otros me dio rabia no haberme enterado de cómo me había muerto. Por eso empecé a pensar en lo ocurrido el día anterior, desde que me encontré con Seve (Fantasmas de día: 7).

Más frecuente es el narrador protagonista que el que se identifica con un personaje secundario. Sin embargo, podemos aludir a un tipo de narrador que aparece con cierta asiduidad, como es el que participa en una colectividad que en los textos suele figurar referencialmente como «nosotros». Así ocurre en Me importa un comino el rey Pepino o en El pequeño Nicolás de Sempé:

Empezó mucho antes. Pero no nos dimos cuenta hasta el pasado domingo de Pascua, a la hora del desayuno. Primero hizo un ruido. Yo creí que se había caído algo en la cocina. Mamá fue a ver, y cuando volvió, temblaba y nosotros... Pero, probablemente, tengo que contar primero quiénes somos. Somos el abuelo, papá, mamá, Martina, Niki y yo (Me importa un comino el rey Pepino: 11). 
Esta mañana llegamos todos a la escuela muy contentos, porque van a sacar una foto de la clase, que será para nosotros un recuerdo que nos gustará toda la vida, como ha dicho la maestra. También nos dijo que viniéramos muy limpios y bien peinados (El pequeño Nicolás: 11).

Este tipo de narrador que se identifica dentro de un «nosotros» y no acaba de individualizarse obedece a una presencia muy habitual en la narrativa infantil dirigida a niños a partir de 10 años, lo que responde al tipo de vivencias que en ese momento cronológico el receptor suele experimentar. El protagonista grupal, por otra parte, arranca en el siglo XIX de la mano de autoras como Blyton y las aventuras de Los cinco y llega hasta nuestros días de la mano de El equipo Tigre, por ejemplo.

\section{B) El narrador no participante}

El narrador que no participa en la historia se identifica con lo que Genette denomina, en lo que concierne a los niveles narrativos, narrador extradiegético (1989a: 284) en relación a su propia narración (cf. García Landa, 1998: 301-304). En principio, todo narrador se define como extradiegético en su vinculación con su propia narración. Ahora bien, el narrador que no participa en la historia que cuenta puede optar por presentarse como un narrador personal e individualizado, puede aparecer como una instancia totalmente despersonalizada o bien puede adquirir la forma de un narrador cámara, lo que supondría, por otra parte, un camino hacia la anulación del narrador como categoría enunciativa. Este último en el campo de la narrativa infantil no existe si nos referimos al texto exclusivamente. No podríamos decir lo mismo de la ilustración, que, en algún caso, como ocurre en No quiero el osito, de McKee (cf. capítulo II: 30), se identifica con la funcionalidad de este narrador cámara que acabamos de mencionar.

En lo que concierne al discurso que nos ocupa, lo más común es la presencia de un narrador despersonalizado, es decir, no individualizado, no marcado, tanto en los álbumes infantiles, en los cuentos, como en la novela infantil. Este narrador no marcado, que siempre se suele identificar con un ser masculino, a no ser que en la cubierta aparezca el nombre de una autora, suele ser reconstruido en función del autor de la obra.

Quizá con demasiada frecuencia Marta siente ganas de llorar; tiene bien ganada fama de llorona. Pero los demás no se dan cuenta de las sutiles diferencias de sus llantos, que no siempre son iguales, aunque pueda parecerlo (Martínez Vendrell, Yo las quería: 6). 
Munia tenía miedo de los cocodrilos y tenía miedo de los cocodrilos desde que se le cayeron los dientes de delante. Un día se le cayó uno, y, al poco, se le cayó el otro (Balzola, Munia y el cocolilo naranja: 3).

Una mañana Sepo se sentó en la cama. - Tengo muchas cosas que hacer — se dijo-. Las escribiré todas en una lista para que no se me olviden. Sepo escribió en una hoja de papel: Lista de cosas que tengo que hacer hoy. Luego escribió: Despertarme (Lobel, Sapo y Sepo, inseparables: 6).

Un día Ernestina Laburnum, la bella bibliotecaria, fue raptada por unos malvados bandidos. Acababa de salir a pasear por el bosque, situado en las proximidades de la ciudad, cuando los bandidos la asaltaron y se la llevaron (Mahy, El secuestro de la bibliotecaria: 5).

Era sábado: el día en que sus padres salían de casa por la noche. —¿A dónde vais hoy?- quiso saber Anton por la tarde, cuando su madre se estaba poniendo los rulos en el baño. [...] Afortunadamente, su madre había vuelto a la tarea de rizarse el pelo, de modo que ya no podía ver cómo el rostro de Anton se ponía colorado (Sommer-Bodenburg, El pequeño vampiro: 15).

Ahora bien, en el caso del discurso narrativo infantil, este autor - no marcado - recuerda, en algunas ocasiones, ayudado por la introducción de fórmulas de inicio propias de los cuentos populares, al narrador que se erige en voz de la colectividad, narrador que, por otra parte, es familiar al receptor infantil desde sus primeros años:

Así es como empieza esta historia. En una oscura, oscura colina, había una oscura, oscura ciudad. En la oscura, oscura ciudad, había una oscura, oscura calle. En la oscura, oscura calle, había una oscura, oscura casa. En la oscura, oscura casa, había una oscura, oscura escalera. Bajo la oscura, oscura escalera, había un oscuro, oscuro sótano. Y en el oscuro, oscuro sótano... (Hnos. Ahlberg, ;Qué risa de huesos!: 3).

Hubo una vez largo tiempo atrás siete lavanderas. Cada día iban a la orilla del río con sus cestas de ropa sucia sobre la cabeza. Se llamaban Mariana, Robustiana, Benita, Paquita, Pepita, Adela y Carmela. Las siete se entendían muy bien. Cuando llegaban al río descargaban la ropa, la separaban y la hundían en el agua (Yeoman, La rebelión de las lavanderas: 3-6).

Había una vez un sombrero. Un sombrero de copa negro, reluciente como el satén, y ceñido por una cinta de seda de color magenta. El sombrero vivía feliz en la cabeza de un hombre rico. Un día, circulando a gran velocidad en un coche descubierto, el sombrero voló (Ungerer, El sombrero: 2-4).

Este tipo de narrador, remedo del que aparece en el cuento popular, es más común en la narrativa dirigida a los primeros años que en las obras dirigidas a edades superiores a los 10 años. 
El narrador personal, es decir, el narrador individualizado, aparece en menor medida que el narrador mencionado anteriormente. Su presencia suele coincidir con el ámbito de la narración dentro de la narración (narración intradiegética) y no es infrecuente que el papel del narrador lo desempeñe algún animal, en la línea de la fidelidad a la tradición oral, del respeto al animismo que preside la visión infantil y del distanciamiento que implica la uitilización de este tipo de trasunto:

«Papá, ya estamos en la cama» — dijeron los ratoncitos. «Anda, cuéntanos un cuento.» "Mejor que eso» — dijo Papá. «Os contaré siete cuentos, uno para cada uno, si me prometéis dormiros en cuanto acabe». «Sí, sí, nos dormiremos» — dijeron los ratoncitos. Y Papá empezó... (Lobel, Historia de ratones: 8-10).

Abuela Osa se sentó en el cenador y Osito le pidió:

- Cuéntame un cuento de cuando Mamá Osa era una osezna pequeñita. El de Mamá Osa y el petirrojo me gusta mucho. - Muy bien - dijo la Abuela Osa. Y empezó a contar: Un día de primavera cuando Mamá Osa era pequeña, encontró un polluelo de petirrojo en el jardín (Minarik, La visita de Osito: 22-24).

Dentro de la categoría del narrador extradiegético, nos podemos encontrar con un narrador personalizado, que se presenta en el inicio de la narración, y que utiliza la tercera persona en la narración intradiegética. Es el caso del narrador de Algunos niños, tres perros y más cosas, de Farias:

No sé si el cuento que ha venido a entristecerme es para niños; puede ser un cuento de niños para padres o para que un padre y su hijo lo escuchen cogidos de la mano. Empieza así: Hace muchos, muchos años, en la antigua China, en una ciudad de papel y barro, blanca de caolín, entre plantas de arroz y té, un niño igual que todos los niños volaba su cometa (11).

No es difícil, por otra parte, adivinar la identificación del narrador en primera persona con el autor textual, aspecto ya comentado anteriormente.

\subsubsection{Narrador único o narrador múltiple}

Es también sugerente, al adentrarse en el discurso narrativo literario infantil, el análisis del número de narradores que se responsabiliza de la narración. En este sentido, se puede distinguir la presencia de uno o varios narradores. 
En el ámbito que nos ocupa es bastante generalizada la presencia de un solo narrador. Así en la narración dirigida a los más pequeños, este tipo de narrador suele ser bastante habitual. Perro y gato, de Alcántara y Asensio; Munia y el cocolilo naranja, de Balzola; Matrioska, de Inkiow y Rius; o jJulieta, estáte quieta!, de Wells, constituyen ejemplos de lo que acabamos de exponer. No obstante, la presencia de varios narradores que comparten la misma narración no es inusual en la narrativa infantil. En todo caso, en el momento en que aparecen varios narradores, estos no comparten el mismo nivel de ficción sino que uno de ellos se identifica con un narrador intradiegético. De este modo, se define el narrador en obras como La visita de Osito, de Minarik; No nos podemos dormir, de Stevenson; o Historia de ratones, de Lobel. En todos los casos expuestos se trata de una narración intradiegética, es decir, de una narración dentro de otra narración.

En lo que respecta a la narrativa dirigida a receptores de 8 años en adelante, es común la presencia del narrador único: Querida abuela, tu Susi, de Nöstlinger; La reina calva, de Company; Charlie y la fábrica de chocolate, de R. Dahl; El vendedor de agujeros, de Mendo; o Elvis Karlsson, de Gripe, por citar algunos ejemplos. Del corpus utilizado, así como de las indicaciones que se desprenden de las últimas publicaciones preocupadas por la lectura de calidad (cf. Barrena, 2000), se infiere que la utilización de varios narradores en el mismo nivel de ficción no es la norma común. Obras como La abuela, de Härtling; De Victoria para Alejandro, de Molina; o El cuarto de las ratas, de Gómez Cerdá son paradigmas aislados de estos narradores que comparten nivel de narración. En La abuela se combinan el narrador en tercera persona despersonalizado con las reflexiones de la abuela en primera persona. De la misma forma, en De Victoria para Alejandro, la narración en tercera persona deja paso en el final de cada capítulo a las cartas que Victoria dirige a Alejandro. En El cuarto de las ratas, el narrador en tercera persona, también despersonalizado, se complementa con las reflexiones interiores de la protagonista en segunda persona, a través de las cartas enviadas a Rocío.

Karli no comprende que la abuela hable siempre de otros tiempos. A la abuela no le interesa gran cosa lo que le pasó ayer mismo, pero de las cosas que le ocurrieron hace treinta o cuarenta años sigue acordándose perfectamente. [...] Este chico tiene que saber cómo eran las cosas antes, cuando yo era joven, por ejemplo, y no me llamaba todavía Erna Bittel sino Erma Mauermeister, mi nombre de soltera (La abuela: 29 y 34). 
Si bien es verdad, sin ánimo de generalizar, que la presencia de un narrador múltiple en el mismo nivel de ficción comienza a apuntar en obras que, a nuestro juicio, abren caminos nuevos en la narrativa de los últimos tiempos. Nos referimos, por ejemplo, a El grito de la grulla, de Alonso. En ella se combinan tres narradores y tres formas de narrar: la primera persona correspondiente al protagonista, la tercera que remeda la voz tradicional y un narrador neutro - a medio camino entre la primera y la tercera- que cede la palabra a los personajes sin inmiscuirse en la acción. Los tres narradores contribuyen a ofrecer diferentes realidades que, al fin y a la postre, dibujan un mundo en continua evolución:

Anoche soñé que mil grullas volaban por el cielo de mi habitación. Soñé que sus grandes y puntiagudas alas me abanicaban y que sus picos habían enmudecido y ya no graznaban ruidosas como siempre (El grito de la grulla: 9).

Érase una vez un hombre muy pobre que vivía en Japón. Se llamaba Kikuchi y era tan pobre que sólo comía el poco arroz que daban sus tierras y con eso se conformaba (El grito de la grulla: 41$)$.

Tenemos que doblar — siguió el maestro con su explicación de cómo hacer la grulla - por las líneas de rayas de las esquinas 6 y 7 hasta el centro. Y después, doblaremos la esquina 5 (El grito de la grulla: 49).

Más habitual es la presencia de varios narradores que pertenecen a niveles de narración diferentes. Así una narración marco que engloba a las demás marca este tipo de narrador múltiple. De este modo, ocurre en $E l$ león mariposa, de Morpurgo; Romanies, de M. Osorio; Si quieres pasar miedo, de Sommer-Bodenburg; o Las telarañas de Carlota, de White, en las que una narración marco introduce a los demás narradores que pertenecen a un nivel de ficción de segundo grado. Del análisis expuesto se puede inferir que el narrador múltiple, en su variante intradiegética, está presente en los libros dedicados a los primeros lectores y en las narraciones dirigidas a receptores mayores de 10 años. Por otra parte, el narrador múltiple en el mismo nivel de ficción sólo se contempla en casos aislados, más bien excepcionales, en la narrativa que se acerca a la literatura juvenil.

Además de estas funciones que llaman la atención sobre el hecho mismo de contar, hay que aludir a la presencia de la función persuasiva y, por extensión, docente en los textos que muestran este tipo de narrador. La mayor parte de ellos no sólo pretende distraer sino también persuadir, convencer y enseñar: 
Había una vez un ratón muy alto y un ratón muy bajo que eran buenos amigos. Cuando se encontraban Ratón Muy Alto decía: «Hola, Ratón Muy Bajo!». Y Ratón Muy Bajo decía: «Hola, Ratón Muy Alto!». Los dos amigos solían ir a pasear juntos. Cuando paseaban Ratón Muy Alto decía: «Hola, pájaros!». Y Ratón Muy Bajo decía: «¡Hola, escarabajos!». [...] Pronto pasó la tormenta. Los dos amigos corrieron a la ventana. Ratón Muy Alto aupó a Ratón Muy Bajo para que pudiese ver. «iHola, arco iris!», dijeron los dos juntos (Lobel, Historia de ratones: 27 y 32-33).

Aunque en algún caso pueden coincidir con las funciones asignadas a la narración intradiegética en los relatos dirigidos a los primeros lectores, las narraciones de este mismo tipo que aparecen en las obras destinadas a los receptores a partir de 10 años —en principio— no cumplen la misma función. Casi todas ellas obedecen más bien a la función explicativa; se trata de relatos homodiegéticos que comparten con el primer nivel de ficción personajes y acciones. Así, por ejemplo, ocurre en Romanies, de Osorio, obra en la que la abuela cuenta a Loles su propia historia que en realidad se convierte en una defensa de las costumbres y de las tradiciones de un colectivo social muchas veces marginado. La función explicativa, sin embargo, en muchas ocasiones, comparte su lugar con la función persuasiva. La razón por la cual se produce esta circunstancia puede coincidir con lo que define Colomer (1998: 263) como "protección del destinatario", es decir, existe una preocupación por parte de los emisores por el hecho de que el lector no se pierda en el transcurso de la narración. A ello habría que añadir la desconfianza en la competencia del receptor. Por eso, en el caso de las narraciones dirigidas a los más pequeños es común la presencia de un narrador único y, si es múltiple, siempre obedece a niveles de ficción en distintos grados con una función, como ya hemos definido, obstructiva o distractiva y además persuasiva. En lo que respecta a las narraciones destinadas a niños mayores de 10 años, la presencia de un narrador múltiple no es la norma habitual. En las obras en las que se encuentra, este tipo de narrador obedece a la función explicativa en combinación con la persuasiva. El emisor, en estas circunstancias, parece confiar más en la competencia del destinatario y, por esta razón, ofrece relatos más complejos desde la perspectiva de los niveles y de las funciones que las narraciones metadiegéticas desempeñan.

En lo que concierne a las narraciones que implican un lector entre $8 \mathrm{y}$ 10 años, la presencia del narrador múltiple constituye una excepción. La razón por la que se explica esta ausencia como norma habitual puede estar 
vinculada a que las narraciones que están dirigidas a receptores de la edad mencionada suponen un tipo de narración transicional que mantiene un narrador a medio camino entre la narrativa de los bloques anterior y posterior. Se opta entonces por un narrador único responsable de una historia más extensa, menos fragmentada, en la que la introducción de un narrador intradiegético con una función explicativa complicaría sobremanera la técnica del relato. Por otra parte, el narrador intradiegético propio de la narración para primeros lectores fragmentaría excesivamente la narración convirtiéndola en pequeños cuentos independientes que destruirían la línea del relato.

La interferencia entre los niveles narrativos u ontológicos, la metalepsis (Genette, 1989a: 289, y 2004), en el discurso narrativo literario infantil no es demasiado común. Encontramos, sin embargo, ejemplos de la utilización de este recurso que extraña al receptor. De este modo, se produce la transgresión tanto de niveles como de estatus ontológico en tres obras de las que aparecen en el corpus: ¡Papá!, de Corentin; Los osos de Nise-sabe, de Varvasovszky; y Los apuros de un dibujante de historietas, de Farias. En la primera narración se produce una transgresión de la frontera entre el mundo real del protagonista-niño y el mundo posible que protagoniza el monstruo. No es el texto el que marca la ruptura sino la ilustración la que sugiere tal recurso. En Los osos de Ni-se-sabe la ruptura es de nivel narrativo y una vez más la ilustración desempeña un papel fundamental en el desarrollo de este recurso:

Pero cuando abro la puerta se me cae el cigarrillo del susto. Porque en la habitación de al lado se han instalado veinte cocodrilos que han devorado todos mis libros. Inmediatamente vuelvo a cerrar la puerta y echo el cerrojo. Tendré que explicarle al niño que, en semejantes condiciones, hoy no puedo leerle su cuento. Estoy seguro de que lo comprenderá. Así es que para que no se dé cuenta, tomo un libro de notas en el que todavía no he escrito nada y leo: Los osos blancos del país de Ni-se-sabe tienen visita. Tengo ante mí solamente unas hojas en blanco. Pero invento un episodio nuevo del cuento cada vez que paso una página... Y eso mismo es lo que esta vez estoy haciendo con este libro, sólo que esta vez escribo la historia y, al mismo tiempo, le pongo dibujos. [...] En este momento el niño me interrumpe, ¡Ah!, por cierto, se me olvidaba deciros que se llama Julián (2-4).

El narrador crea un niño imaginario —Julián—, quien, a su vez, desempeña el papel de destinatario del cuento. Este personaje, sin embargo, opina sobre el desarrollo del cuento e incluso desea intervenir cuando 
los osos blancos se encuentran en peligro aunque el narrador se lo prohíbe. La ilustración del libro también lleva a cabo la misma ruptura de niveles.

Por último, en la narrativa ya dirigida a niños de mayor edad, Los apuros de un dibujante de historietas se basa en la ruptura de niveles narrativos y de estatus ontológico:

Jacobo era dibujante de historietas y escritor de cuentos. También dibujaba tarjetas de Navidad y escribía las cartas de negocios a un señor analfabeto. [...] Aquel día, como tantos, Jacobo se sentó delante de su tablero, cogió el lápiz y entonces se dio cuenta de que no sabía por dónde empezar. [...] Entonces vio a un niño descalzo y despeinado y lleno de preocupaciones. De vuelta a casa, ya en su estudio, Jacobo dibujó al niño que había visto. Después, para hacerlo sonreír, preguntó: —¿Te gustaría ir a cazar grillos? El niño dijo: —Antes quiero saber dónde estoy (9 y 11).

Los dos últimos textos aducidos versan sobre la creación y apoyan la ruptura en el código de la imagen, que trabaja el mismo recurso. En principio, la utilización de este tipo de técnica podría resultar no demasiado adecuada a la recepción infantil, puesto que implica la existencia de un receptor con una competencia literaria más desarrollada. La ilustración desempeña un papel fundamental en estos textos. En Los osos de Ni-sesabe se encarga de dirigir la narración y el texto funciona como guía, tal como hemos señalado al tratar los álbumes ilustrados. En el discurso de Farias - libro ilustrado- la ilustración apoya la lectura del texto de tal forma que el receptor puede utilizarla como guía en el desarrollo de la acción. Las rupturas de marco, que siempre constituyen un recurso expresivo muy atractivo, cuando aparecen en el ámbito que estamos analizando, implican una actuación simultánea de los dos códigos que intervienen en el libro infantil. La imagen, en estos casos, se convierte en un elemento no subsidiario sino indispensable en la recepción e interpretación del discurso.

De este modo, ocurre en El libro que tenía un agujero, obra en la que se juega con los diferentes niveles de ficción a través de la complicidad que establecen texto e imagen nuevamente. Así, el juego metaficcional se define como una de las tendencias de parte de la literatura infantil de nuestros días. Este tipo de discurso implica una colaboración del receptor en la construcción de significados y redunda en la línea de la posmodernidad tan característica de los últimos años en el ámbito del libroálbum. 


\subsubsection{Las funciones del narrador}

Contribuyen asimismo a definir la identidad del narrador las funciones que desarrolla el mismo dentro del discurso. Es una vez más Genette (1989a: 308 y ss.) quien, basándose en los elementos de la situación comunicativa distinguidos por Jakobson, determina las posibles funciones del narrador: función narrativa — transmisión de la acción-, función administrativa — construcción del discurso-, función comunicativa - establecimiento de una orientación hacia el narratario-, función testimonial - relaciones entre narrador y acción- y función ideológica — comentarios que el narrador realiza sobre la acción.

Las dos primeras funciones mencionadas son obligadas en toda narración y el discurso narrativo infantil no escapa a esta máxima. Es el narrador, a veces confundido con el autor textual que se encuentra detrás de él, quien transmite la acción y construye y organiza el texto. ${ }^{13}$ En este sentido, hay que destacar en el discurso narrativo infantil la presencia de la primera persona identificada con un narrador infantil que organiza y elabora eficazmente su narración cuando a él se le supone, por su edad, una limitación en el uso de ciertos recursos expresivos. Ocurre esto en obras como No sé, de Piérola; iiiPapááá...!!!!, de Cano; Ha sido el pequeño monstruo, de Cooper; Fantasmas de día, de Baquedano; El vendedor de agujeros, de Mendo; El pequeño Nicolás, de Goscinny; o en Las brujas, de Dahl, por citar algunos ejemplos que antes hemos mencionado al hablar de la primera persona.

13 Algunos autores (Sánchez Rey, 1991: 264) entienden la función de rección como una reflexión metatextual. Aun concibiendo de esta forma extrema lo que Genette define como función rectora, aparecen textos infantiles como Los osos de Ni-se-sabe que desarrollan hasta el extremo la reflexión del relato sobre sí mismo. De este modo, el narrador de Me importa un comino el rey Pepino, de Nöstlinger potencia esta función en su esfuerzo por escribir de acuerdo con las instrucciones del profesor de lengua:

«EN EL DECIMOTERCER CAPÍTULO NO HAY MUCHO QUE ESTRUC-

TURAR. Esperamos. Seguimos esperando. Además naturalmente, leemos. Y como todo esto es muy poco para un capítulo, cuento también lo que pasó la día siguiente en el colegio. Lo que pasó fue algo que dejó a todos asombrados» (113).

No obstante, en el transcurso de la exposición hablaremos de función de rección en un sentido más amplio que el que supone la vinculación a una relación metatextual. Cf. asimismo Booth, 1974: 155; Prince, 1982: 12; y Tacca, 1973: 113 y ss. 
No sé dónde estuve antes de estar aquí. No sé por qué somos tantos. O tan pocos. No sé quién mueve el sol desde tan alto o dónde se enchufa la luna. No sé dónde aprendió el lápiz a hacer dibujos. O por qué las nubes se dibujan solas. No sé por qué cuando me caigo, me bailan puntos rojos bajo la piel. O por qué se me eriza cuando voy al baño. No sé por qué no tengo pelos como tú, o por qué no camino con mis cuatro patas. No sé qué gigante llora al mar. O por qué los ríos tienen tanta azúcar (No sé: 5-10).

En narrativa infantil cuando aparece la primera persona como narradora suele identificarse con el niño, sea éste protagonista o no. En el texto que acabamos de proponer extraído del álbum de Piérola, el narrador es un niño de muy corta edad, tal como nos lo muestra la ilustración. Las imágenes que ofrece el texto verbal — «enchufar la luna», "gigante que llora al mar»- observan el principio de verosimilitud propio del lenguaje infantil; se encuentran en la línea del pensamiento animista y mitológico propio de la psique infantil en los primeros años. Sin embargo, no podemos atribuir al narrador la pensada elaboración del discurso que se hace eco de las principales preguntas del niño ante lo que observa a su alrededor. Esto se le atribuye al narrador real, al autor textual, que es quien, en última instancia, administra la retórica del texto aunque delegue parte de ella en un personaje de ficción. Cualquier narración infantil que opte por presentar un narrador en primera persona identificado con un personaje infantil debe analizarse en la misma línea. Incluso en las obras en las que se pretende observar la omnipresencia del narrador infantil en la elaboración del discurso, como puede ocurrir en las que se articulan a través de la técnica epistolar como Querida abuela, tu Susi, de Nöstlinger, es necesario contar con la actuación del autor textual como elaborador último del discurso.

Aunque se encuentre en la frontera del marco cronológico de recepción que nosotros hemos elegido, es obligado comentar, en este sentido, Manolito Gafotas, de Lindo. En esta obra se cuida en extremo todo lo referente al lenguaje que utiliza Manolito para contar todo aquello que le sucede en su entorno; no obstante, la elección de las acciones, la fragmentación en capítulos, en definitiva, la organización y la disposición del orden de los sucesos se deben al autor textual:

Al empezar septiembre mi madre nos mandó a mi abuelo y a mí a comprar un cuerno que me faltaba en la trenca. Me lo arrancó el año pasado el Orejones López de un mordisco, un día que no le quise dar bocadillo. Él se rompió un diente y yo me quedé sin cuerno. A él le consoló su madre y a mí 
la mía me dio una colleja de las de efecto retardado, de las que te duelen a la media hora aproximadamente. Ese día aprendí que si quieres meterte una madre en el bote es mucho mejor que te rompas algo de tu propio cuerpo a que te rompas algo de la ropa (Manolito Gafotas: 13).

Expresiones como «de un mordisco» o "colleja de las de efecto retardado» son muy propias de los niños de la edad del narrador; sin embargo, la elaboración ulterior del discurso no se le debe al narrador sino al autor textual, que, en algunos casos, delega en el protagonista infantil. Desde luego, hemos de reconocer que la mayor parte de los narradores infantiles que aparece en las obras de los últimos años del siglo XX resulta verosímil en la utilización que realizan de su lenguaje y de las imágenes que en él se vierten. Por señalar un punto de referencia, comprobemos qué diferencia existe entre la verosimilitud de Manolito y de Veva, protagonista de la obra que lleva el mismo título, de Kurtz:

Yo sé que Buela está esperando el domingo para ver a mis padres desayunarse juntos y sentados a la mesa; los otros días lo hacen en la cocina y al vuelo. El olor del café con leche y de los croissants es delicioso. Yo me quedo con la Buela, en la cocina mientras los papás se desayunan. Quique, a menudo, lo hace con ellos. Alberto llega cuando casi han terminado y Natacha es siempre la última. Se sienta a la mesa desgreñada, bostezando con la bata tirada sobre los hombros. Buela no dice ni pío, pero aquello no le gusta nada. A ella nunca la he visto en bata (Veva: 40).

Veva, a pesar de ser una niña dotada de unas cualidades especiales, no se expresa como correspondería a una niña sino como un adulto. La verosimilitud, pues, no se observa, rasgo que, por otra parte, se lleva a los extremos, dentro de lo posible, en la narrativa infantil de los últimos años del siglo XX. Así pues, la verosimilitud que reclamaba Aristóteles en su Poética se presenta como uno de los criterios valorables a la hora de enfrentarse al discurso infantil de nuestros días (cf. Colomer, 2002c: 80-81). Es necesario hablar de verosimilitud puesto que la imitación nos llevaría al absurdo en el caso de los narradores infantiles, a un discurso incomprensible.

La función comunicativa, es decir, el establecimiento en el discurso de una orientación hacia el narratario, junto a la función testimonial e ideológica, son definidas por Genette (1989a: 309) como opcionales, en el sentido de que algunos las llevan a cabo y otros no. Estamos de acuerdo, no obstante, con las consideraciones que al respecto realiza García Landa (1998: 299) cuando manifiesta que «toda narración contiene inevitable- 
mente de modo implícito una orientación hacia el narratario o hacia la acción y una ideología». Si las funciones que establece Genette contribuyen a definir la identidad del narrador, pensamos que es conveniente distinguir entre la función narrativa y la administrativa como esenciales en la identificación del narrador y tratar la función comunicativa en el apartado dedicado al narratario, que en el ámbito del discurso narrativo literario infantil adquiere una importancia decisiva. En lo que concierne a las funciones testimonial e ideológica, por su propia trascendencia en el ámbito que nos ocupa, serán estudiadas más adelante. Si en la narrativa para adultos las cinco funciones pueden ser tratadas de forma conjunta, estimamos que en el discurso narrativo infantil es conveniente separar unas de otras, ya que la función ideológica permanece directamente vinculada al grado de implicación del narrador.

\title{
3.2.2. El grado de información del narrador
}

\begin{abstract}
El narrador adquiere implícita o explícitamente una serie de deberes frente al narratario en lo que se refiere a la transmisión del relato o a la actividad discursiva en general. Estos deberes son los deberes de todo interlocutor en una conversación, definibles por las máximas de P. Grice (García Landa, 1998: 292)
\end{abstract}

Las máximas a las que se refiere García Landa son las que Grice (1989: 26-27) resume en lo que él denomina principio de cooperación. ${ }^{14} \mathrm{El}$ narrador puede o no cumplir con las máximas comunicativas, lo que en el discurso literario adquirirá especial trascendencia estilística.

Dentro de la naturaleza ficticia de la narración, la palabra del narrador posee una validez especial puesto que es el único asidero que tiene el lector para instalarse en el mundo ficticio. Como señala Martínez Bonati (1972: 65), en principio el narrador merece el crédito total del receptor. Parece, por mera lógica, que el narrador autorial heterodiegético es más fiable que la narración homodiegética. Sin embargo, es necesario distinguir dentro de lo que Booth (1974: 159) denomina unreliability - unreliable narrator - entre la ignorancia y la mala fe. El narrador puede incumplir sus responsabilidades con el narratario y puede llegar a ser un

14 Las máximas que distingue Grice (1989: 26) son las siguientes: de cantidad, de cualidad, de relación y de modo. 
narrador incompetente, siempre que detrás de él se esconda una autor textual competente. En este momento es cuando la actividad interpretativa del lector textual se hace decisiva.

En el caso de la narrativa infantil, lo más extendido es la presencia de un narrador fiable que cumple con todos sus deberes, clara herencia de la narrativa popular que opta por un narrador heterodiegético totalmente competente. Este ha sido el lugar común de la narrativa dirigida al público infantil hasta los últimos años del siglo XX, años en los que, como señala Colomer (1999: 112), el juego de experimentación literaria tanto conceptual como formal ha proliferado. El narrador omnisciente que conoce el pasado, presente y futuro de sus criaturas es el que puede leer la mente de los personajes ${ }^{15}$ lo cual implica un estudio detallado de la focalización.

El narrador omnisciente es el narrador con autoridad propio de la narrativa tradicional, que se mantiene hasta nuestros días en el discurso narrativo infantil, sobre todo en las obras que respetan la estructura del cuento popular maravilloso:

En Dormilandia, lo principal para todo el mundo es el dormir. Por eso se llama así el país. Y no es lo más importante cuántas horas pueda uno llegar a dormir, sino lo bien que duerma. Porque existe una diferencia entre dormir y dormir bien. En opinión de los dormilandeses, quien duerme bien es de carácter amable y tiene la cabeza clara. Por eso nombran rey a quien más profundamente logre dormir (Ende, El tragasueños: 4).

Había una vez un niño pequeño que no tenía mamá. Vivía completamente solo en una casa. Él solo se preparaba la comida y él solo se bañaba. Y hasta se tenía que cambiar los pañales él solo. Era muy triste. Una noche, después de acostarse él solo y cuando todavía estaba despierto, pensó: «Soy demasiado pequeño para hacer todo esto. Necesito una mamá». Así que al día siguiente, por la mañana temprano, se marchó a su casa para buscarse una mamá (Hnos. Ahlberg, jAdiós, pequeño!: 5-7).

Pues así calva como la luna llena, era la soberana de un pequeño reino situado entre Valle Chico y Valle Grande. Ya nadie recordaba el nombre de su majestad, puesto que todo el mundo la conocía como «la reina Calva». La reina estaba muy apenada por su calvicie. Todos sus afanes por encontrar una solución fracasaron estrepitosamente (Company, La reina calva: 7-8).

Durante las tardes que siguieron, la señora Phelps apenas quitó ojo a la niñita sentada hora tras hora en el gran sillón del fondo de la sala, con el libro

15 Cf. Kayser, 1985: 274; Friedman, 1972: 121; Stanzel, 1955: 49; Tacca, 1973: 73 y ss.; Lozano, Peña-Marín y Abril, 1982: 134; y Lanser, 1981: 161. 
en el regazo porque era demasiado para sujetarlo con las manos, lo que significaba que debía sentarse inclinada hacia delante para poder leer. Resultaba insólito ver aquella chiquilla de pelo oscuro, con los pies colgando, sin llegar al suelo, totalmente absorta en las maravillosas aventuras de Pip y la señorita Havishman y su casa llena de telarañas dentro del mágico hechizo que Dickens, el gran narrador, había sabido tejer con sus palabras (Dahl, Matilda: 18-19).

Los ejemplos mencionados atestiguan la presencia de un narrador que lo sabe todo, que domina el mundo ficticio que él ha creado. Ahora bien, en las dos últimas décadas del siglo XX se ha asistido a la aparición de narradores que muestran ciertas carencias o desconocimientos y que exigen una actitud cooperante del receptor. En estos casos, la actividad cooperativa del lector se hace decisiva. Así en Mamá fue pequeña antes de ser mayor, de Larrondo y Desmarteau, el narrador comenta lo modélico que fue el comportamiento de mamá cuando era niña. Sin embargo, el lector descubre, a través de la ilustración, que la madre se comportó de la misma forma que su retoño.

Del mismo modo, en iPapá!, de Corentin, el narrador, esta vez en tercera persona, presenta un juego de perspectivas a través del cual el receptor se convence de que el narrador cuenta menos de lo que debería contar con la intención de provocar el extrañamiento. La ilustración, una vez más, ayuda al receptor a interpretar el sentido último del cuento. El narrador se limita a repetir las mismas palabras y a exponer las mismas acciones sin informar del sujeto que las emite o realiza. Su posible incompetencia se resuelve a través de las imágenes que, al menos, aclaran la identidad del personaje al que el narrador se refiere.

Lo mismo ocurre en No quiero el osito, de Mckee, álbum en el que el narrador sólo cuenta una de las muchas historias que el libro expone, la que se refiere a la discusión que entablan dos niños acerca de las virtudes excepcionales de sus ositos. La ilustración, sin embargo, expone otras muchas historias que el receptor tendrá que recomponer con la ayuda de las imágenes y a través de sus propias inferencias.

Hasta aquí hemos propuesto ejemplos de narradores no demasiado fiables en los álbumes infantiles. Hasta cierto punto, la presencia de un nivel mayor de experimentalidad basado en el poder expresivo de la imagen es previsible en este tipo de libros. De igual manera, No sé, de Mabel Piérola, incide en este tipo de narrador poco fiable, y que, a su vez, presenta una visión parcial de la realidad utilizando de punto de apoyo la ima- 
gen. Ahora bien, no es desconocida en el discurso narrativo literario infantil la presencia de varios narradores que ofrecen distintas versiones de la historia central. Así en La abuela, de Härtling, existe un narrador en tercera persona que corresponde a la perspectiva del niño protagonista y un narrador en primera persona, distinguido tipográficamente por dos líneas horizontales que encuadran las intervenciones de este narrador subrayadas asimismo por la utilización de la letra cursiva:

Karli no podía imaginarse que la abuela cayera enferma. No lo estuvo durante mucho tiempo pero poco antes de que Karli cumpliera los diez años sucedió aquello que él temía en secreto. Durante varios días la abuela trató de ocultarlo. Se quedaba más tiempo que de costumbre en la cama, le pedía que se hiciera él mismo el desayuno, apenas repartía prospectos, enviaba a Karli a la panadería — hacía, en resumen, un montón de cosas raras-. [...]

Esto se acaba, Erna Bittel, pensé. Y cuando el muchacho se fue corriendo a buscar al médico volvieron a desfilarme por la cabeza todas esas cosas. ¿Qué iba a ser de él? ¿Quién iba a recogerlo? ¿Iría Karli a parar a un asilo? Hubiera querido levantarme tan sólo para que nadie notara nada, pero me sentía terriblemente mal y pensaba en la muerte (Härtling, La abuela: 91 y 100).

En principio, el receptor se encuentra ante un problema de focalización, por una parte, y ante una cuestión atingente a la voz, por otra. Cada uno de los narradores muestra al receptor acciones diferentes que corresponden a la misma historia. El receptor construye la historia a partir de dos visiones distintas, más o menos fiables las dos, pero complementarias. Ninguno de los dos narradores acaba de contar la historia completa sino que ofrecen versiones diferenciadas de los mismos hechos con el fin de que el lector construya su propio significado.

Asimismo, es necesario contemplar la existencia de narradores no demasiado fiables como el de Fantasmas de día, de Baquedano, que narra la historia de unos niños que creían estar muertos y luchan por la liberación de sus almas, hasta que, al final, se dan cuenta de que nada era como ellos habían creído:

No puedo explicármelo, pero nos veían. Nos veían todos, y fue inútil intentar hacerles comprender que éramos fantasmas. Nadie lo creía. Todos nos habían visto entrar en sus casas, y su asombro no se debía a que se abrieran y cerraran las puertas y ventanas sino a nuestras payasadas (Fantasmas de día: 80).

No se trata en ningún caso de narradores ignorantes, puesto que, como muy bien determina Prince (1982: 149), la narratividad y la igno- 
rancia no suelen ir en unión y el narrador está vinculado al conocimiento. Presentan estos narradores un grado de conocimiento menor que el que corresponde al narrador omnisciente ${ }^{16}$ por antonomasia y exigen una cooperación mayor por parte del receptor; de tal modo que podríamos establecer que a menor conocimiento por parte del narrador, mayor colaboración se le exige al lector en la interpretación de la obra. En principio, como hemos señalado anteriormente, el narrador homodiegético en primera persona es menos fiable, en cuanto a conocimientos se refiere, que el narrador autorial que, en buena lógica, conoce más acerca de la acción y de sus protagonistas. En el discurso narrativo infantil de los últimos años la presencia del narrador homodiegético infantil es bastante frecuente, es decir, el discurso se aleja de la fiabilidad del narrador autorial para ofrecer un narrador no tan fiable, más sesgado, pero mucho más cercano al receptor a quien, por otra parte, se facilita el proceso de identificación por proximidad de apreciaciones y, en algunos casos, el distanciamiento humorístico que justifica la referencia a aspectos excesivamente comprometidos. Obviamente nos estamos acercando al aspecto de la focalización, aspecto que vamos a tratar en el próximo apartado.

\subsubsection{La situación del narrador}

La posición que observa el narrador para contar contribuye a la definición del narrador. Además de la identidad y del grado de conocimiento, todo lo concerniente al lugar en el que se ubica el narrador para contar adquiere suma importancia en el estudio del narrador. Este puede caracterizarse desde el lugar que ocupa respecto de la historia o respecto de las figuras.

\subsubsection{La situación del narrador respecto de la historia}

No han sido escasos los intentos de obtener una tipología de las narraciones utilizando como referencia el uso de las personas gramaticales.

16 Obviando el rechazo de la oportunidad del reconocimiento de la omnisciencia propugnado por Genette (1998: 56) o por Bal (1995: 126-132) y dejando claro que en el campo del saber el narrador se mueve entre la ignorancia y la omnisciencia, es necesario señalar que existen estudiosos que tratan de precisar el grado de conocimiento del narrador utilizando expresiones como «omnisciencia selectiva» (Friedman, 1972: 128) u «omnisciencia confinada a un personaje» (Humphrey, 1954: 34). Aunque las expresiones resulten sugerentes, optaremos en este trabajo por mencionar la omnisciencia del narrador, aun conociendo que entre el narrador ignorante y el omnisciente se establecen varios grados. 
Así, se habla de relatos en primera persona, relatos en tercera persona e incluso de relatos en segunda persona. ${ }^{17}$ No es demasiado eficaz la distinción de narraciones atendiendo a la categoría de persona puesto que, como han señalado Genette (1989a: 67 y 1998: 298), Stanzel (1984: 48) o Bal (1985: 187), toda narración por el hecho de serlo remite a un mediador entre el receptor y el mundo representado, es decir, todo discurso narrativo expresa a su narrador y este siempre hace referencia a sí mismo en primera persona. La distinción, pues, entre relato en primera persona y relato en tercera persona es demasiado vaga.

Consideramos con Genette que lo verdaderamente significativo para el análisis del discurso no es la utilización de la persona gramatical sino la elección de actitudes del narrador ante la historia. En esta línea, distinguiremos entre el narrador heterodiegético —ausente en la historia - y el narrador homodiegético — presente en la historia—. La elección de una actitud u otra implicará, sólo como consecuencia, la opción por una persona u otra. Dentro de la narración homodiegética, el narrador se puede identificar con el personaje protagonista (narración autodiegética) o con un simple observador. Cada una de estas situaciones motivará perspectivas o focalizaciones distintas. De todos modos, la frontera entre la narración homodiegética y la heterodiegética no es clara sino bastante confusa. A este respecto, como menciona García Landa (1998: 312), resulta muy útil la propuesta de Lanser (1981: 159) de contemplar la narración autodiegética y la heterodiegética como dos extremos entre los que es posible la distinción de gradaciones diversas. Normalmente, la narración homodiegética resulta más verosímil e incluso más realista que la heterodiegética, ya que no rompe abiertamente los límites de la credibilidad.

En lo que concierne al discurso literario narrativo infantil, el narrador homodiegético no es poco habitual. El narrador homodiegético en primera persona identificado con el protagonista, es decir, el autodiegético, es bastante menos frecuente que el heterodiegético. El narrador autodiegético aparece en menor medida en la narrativa destinada a las primeras edades - No sé, de Piérola; Ha sido el pequeño monstruo, de Cooper; y iiiPapááá...!!!!, de Cano- y es más frecuente a medida que nos acercamos a la

17 Cf. Booth, 1974: 150; Füger, 1972: 272 y ss.; Kristeva, 1974: 134. 
novela infantil: Fantasmas de día, de Baquedano; Las brujas, de Dahl; El pequeño Nicolás, de Goscinny; El vendedor de agujerosm de Mendo; $\mathrm{Me}$ importa un comino el rey Pepino, de Nöstlinger.

En principio, el predominio del narrador que cuenta la historia desde fuera no parecería estar de acuerdo con el proceso de interiorización psicológica al que asiste la narrativa actual. ${ }^{18}$ Además de la justificación a través de la protección del destinatario (Colomer, 1998: 263), creemos que es necesario observar en el discurso literario infantil las instancias narrativas propias del proceso enunciador. Como el discurso literario destinado a los adultos, el discurso narrativo dirigido a los niños se puede justificar desde las instancias enunciativas del propio discurso. Hemos mencionado más arriba que el narrador homodiegético, sobre todo el autodiegético, es más verosímil que el narrador heterodiegético. Esta razón puede explicar el predominio del último sobre el primero en el discurso que estamos analizando. Puesto que lo previsible, dado el elevado índice de presencia de los personajes infantiles (Colomer, 1998: 237-242) en las obras narrativas destinadas a los niños, es la presencia de un narrador autodiegético identificado con el destinatario, el discurso exigiría asimismo una elaboración y organización acorde con el sujeto que la lleva a cabo. Sin embargo, esto no ocurre con los narradores infantiles que se inmiscuyen en la historia que cuentan, ya que ceden la responsabilidad contraída con el discurso al autor textual o al autor que se encuentra detrás o encima de ellos. Se desvirtúa de este modo la esencia del narrador autodiegético en aras de la interpretación del texto por parte del receptor. Si recurrimos, por ejemplo, al álbum Ha sido el pequeño monstruo, de Cooper, podemos comprobar cómo la disposición y ulterior organización del discurso no obedece al narrador sino al autor implícito que se manifiesta como responsable último:

Durante semanas, por la noche, el bebé no quiso dormir. El ruido duró todo el invierno y el Pequeño Monstruo tenía pesadillas. Por eso nos despertábamos y nos íbamos... a ver a mamá. Una noche la cama quedó empapada.- ¡Ha sido el Pequeño Monstruo! - dije. Y era verdad. Había vaciado la bolsa de agua caliente (Ha sido el pequeño monstruo: 11-14).

18 Todo lo que concierne a las innovaciones temáticas en la narrativa infantil de los últimos años ha sido estudiado por Colomer (1998: 224-230). Esta autora comenta con detalle la omnipresencia de los conflictos psicológicos y sociales en las narraciones como elemento característico del discurso que estamos analizando. 
La focalización del relato, además, está constreñida por un personaje y unas características físicas (cf. Stanzel, 1955: 93); lo cual en el caso que acabamos de mencionar en el que la protagonista y narradora es una niña -a juzgar por la ilustración - de unos tres o cuatro años complica todavía más la verosimilitud del discurso en lo que se refiere al narrador responsable y a la interpretación por parte del destinatario. La focalización actorial en la narración autodigética, como hemos comprobado, elimina cualquier intrusión por parte de otro narrador. En los álbumes que presentan un narrador autodiegético es la ilustración la que ofrece las claves de interpretación del texto. Así en la obra Ha sido el pequeño monstruo, la ilustración ofrece imágenes que coinciden con los sucesos relatados por la narradora salvo en un pequeño detalle: las diferentes «trastadas» que se atribuyen al Pequeño Monstruo no constituyen una iniciativa de este sino de la niña protagonista. La ilustración, una vez más, facilita la experimentación literaria en las primeras edades. Por otra parte, en lo que concierne a la narrativa destinada a edades más avanzadas (ocho o diez años), la presencia de narradores autodiegéticos suele combinarse con la de otros narradores adultos que contribuyen a eliminar las exigencias de la focalización actorial, tal como ocurre en ; Que me parta un rayo!, de Barrena, obra en la que se combinan las voces de dos narradores con sus diferentes perspectivas:

¡Que me parta un rayo! Eso es lo que espero que me suceda. Al fin y al cabo, es una muerte natural. No se le había ocurrido nunca una idea mejor a mi único nieto: «Que te parta un rayo, abuelo Perico!» Precioso, el niño, sí. Pero con los padres que tiene, qué se le puede pedir (7).

Mi abuelo es imbécil y mis padres dos idiotas. Sólo se salva mi tía Magda. Ella sí que me hace regalos bonitos, como el chandal italiano. Casi me dan ganas de ponérmelo ahora. Pero cualquiera sale de la cama a estas horas, con la ventana completamente abierta, como le gusta que esté a mi padre. Además, en cuanto encienda la luz, Perico se levanta a ver qué me pasa. Quiere que esté con él todo el día, pero me cansa (10).

Dentro de la esfera del narrador homodiegético, es necesario aludir a un tipo de narrador que, en realidad, resulta ser el autor asumiendo de manera explícita el discurso como obra suya. Esta figura que asume el discurso como suyo, que comenta su propia ficcionalidad y que, en tanto que habla como autor, supone una interacción comunicativa con el lector, se encuentra en algunas obras, como La larga siesta de papá, de Farias; El planeta de los árboles de Navidad, de Rodari; Te quiero, Valero, de Lalana; Pelo- 
tieso y Ricitos de Oro, de Monreal y Lalana; o Caramelos de menta, de Vázquez-Vigo.

No sé si el cuento que ha venido a entristecerme es para niños; puede ser un cuento de niños para padres o para que un padre y su hijo lo escuchen cogidos de la mano. Empieza así: Hace muchos, muchos años, en la antigua China... (La larga siesta de papá en Algunos niños, tres perros y más cosas: 11).

Todo esto ocurrió si es que en verdad ocurrió hace unos mil años siglo más, siglo menos. En una época tan lejana que aún era posible encontrar dragones en libertad; y no como ahora, que viven todos atrapados entre las páginas de libros como éste. Nuestro protagonista, precisamente, es un dragón. Un dragón auténtico, con su fuego y sus escamas. ¿Que cómo se llamaba? ¡Bah! Los dragones no tienen nombre no lo necesitan. Pero para entendernos - sólo para entendernos - lo llamaremos Valero. Aunque si Valero no te gusta, puedes llamarlo Ángel o Lorenzo a mí me da igual. A Valero le encantaba ahacer excursiones a pie por su territorio que, casualmente, también es el nuestro (Te quiero, Valero: 6-9).

La primera vez que conté esta historia, nada más oír la palabra «trinóculo», se me acercó un señor y me dijo en voz baja: - Mal comenzamos, jovencito. ¿Hombre al cielo? ¡Vaya coladura! Hasta los niños saben que se dice "iHombre al agua!». [...] Pero cerremos ya el paréntesis y volvamos al principio (El planeta de los árboles de Navidad: 8 y 10).

Tenía la cabeza grande, las patas cortas y el rabo indeciso, porque apenas iniciaba una gallarda curva hacia arriba, volvía a caer como si le hubieran hecho un nudo en medio. Pero hemos de decir en su favor, porque es cierto, que tenía una expresión inteligente y simpática, como de perro golfo que era (Caramelos de menta: 8).

El autor del que estamos tratando, el autor-narrador (García Landa, 1998: 321), no coincide con el autor real sino que se identifica con el autor textual explícitamente presente en el discurso. Comprobaremos, al hablar del narratario, cómo este tipo de narrador que establece contacto directo con el receptor del discurso no es ajeno a la narrativa infantil sino más bien todo lo contrario. ¿Remedo de la tradición oral? No hay que descartar la posible influencia de esta tradición en lo referente a la narrativa, sobre todo, en la dirigida a las primeras edades. Sin embargo, creemos oportuno profundizar un poco más en este tipo de narrador, que no se puede explicar sólo desde la perspectiva de la influencia de la cuentística popular, aun siendo cierto que el narrador-autor recuerda al contador de cuentos en la situación de enfrentarse a un público presente que va a retroalimentar el acto de la narración con su cooperación in situ. Este narrador 
resulta muy cómodo en la construcción del discurso narrativo infantil puesto que establece un marco desde la primera persona, ajena a lo que va a contar, para pasar después a la tercera, que se responsabiliza del grueso del discurso sin que por ello el narrador-autor tenga ningún inconveniente en inmiscuirse en la historia cuando lo crea oportuno, a manera de paréntesis, desde una perspectiva verosímil. Este narrador que se muestra en el discurso explícitamente como autor es siempre un adulto, lo cual abunda todavía más en el principio de verosimilitud y facilita la intromisión de ciertos comentarios al hilo del desarrollo de la historia:

El doctor refunfuñó algo a media voz, se alisó la raya de los pantalones, recordó entonces que tenía algo que hacer y desapareció en la oscuridad de la noche sin esperar a oír el resto de la historia. ¡Peor para él! (El planeta de los árboles de Navidad: 10).

Los maestros lo pasan muy mal teniendo que escuchar tonterías de padres orgullosos, pero normalmente se desquitan cuando llega la hora de las notas finales de curso. Si yo fuera maestro, imaginaría comentarios genuinos para hijos de padres imbéciles. «Su hijo Maximilian», escribiría, «es un auténtico desastre. Espero que tengan ustedes algún negocio familiar al que puedan orientarle cuando termine la escuela, porque es seguro, como hay infierno que no encontrará trabajo en ningún sitio" (Dahl, Matilda: 11-12).

Por último, es de reseñar que la forma epistolar, muy común en la narración autodiegética, aparece en la narrativa infantil de nuestros días aportando verosimilitud al relato (Sotomayor, 1998). Así ocurre en Querida abuela, tu Susi, de Nöstlinger, narración epistolar en la que el autor textual se hace cargo de la organización del discurso sin necesidad de acudir a figuras propias de la narrativa para adultos como la del editor.

Mención aparte, en este sentido, merece la obra de Atxaga Las bambulisticas historias de Bambulo. Primeros pasos, obra en la que el narrador-autor es fiel al criterio de verosimilitud y justifica cómo han llegado a sus manos los papeles que transcribe introduciendo un prólogo firmado por el secretario de Bambulo, que es la voz escogida por el autor, y dos dedicatorias, una de ellas firmada por el secretario y otra por el propio Bambulo. Este narrador-autor, que escoge como intermediario al secretario, cede en el transcurso de la narración su voz a Bambulo, quien, a su vez, relata sus experiencias en documentos que se identifican con los diarios: 
Prólogo sobre Bambulo escrito por su secretario

Querido lector: el recorrido vital de nuestro personaje ha sido completamente redondo. No quiero decir con ello, de ningún modo, que no haya tenido defectos o no haya dejado lugar a alguna que otra duda, sino que simplemente, comenzó en un punto, dio una gran vuelta y regresó. [...]

Lee, pues, lector, las diversas historias (Las bambulísticas historias de Bambulo. Primeros pasos: 5).

Segundo prólogo. Cómo consegui los papeles y documentos de Bambulo.

Como se sabe, Bambulo vive ahora en su ciudad natal, Bilbao, y allí fue donde le visité. [...] Ya lo he indicado antes. Bambulo es caprichoso. Pero, claro, también es inteligente y honrado. En vez de olvidarse de su promesa, se apresuró a cumplirla. En un par de días, todas las cajas de su desván estaban en mi oficina.

Así fue como comenzó todo. Así fue posible la publicación de estas bambulosas o bambulísticas historias (Las bambulísticas historias de Bambulo. Primeros pasos: 9 y 21 ).

El secretario, pues, ocupa el nivel extradiegético de la narración puesto que él narra lo que se desprende de los documentos de Bambulo. Reorganiza y dispone, en tercera persona, los papeles que el personaje protagonista le ha cedido y salpica la narración de la transcripción de los pensamientos que pertenecen a su diario íntimo, además de documentos, a manera de intertexto, relatados por otros personajes. Se combinan las naturalezas heterodiegética y homodiegética del narrador, dando paso a narradores distintos según la ocasión. En definitiva, la narración se convierte en un juego de voces, como señala Watson al tratar la novela epistolar. ${ }^{19}$

Tratando de justificar la veracidad de la obra, tal como corresponde a unas memorias históricas, el texto resulta introducido por dos dedicatorias, remedando de ese modo la manera clásica propia de los libros de memorias:

Primera dedicatoria. El secretario que tan duramente ha trabajado en este libro dedica su esfuerzo a Bambulo: Apreciada individualidad, querídisimo perro, admirado Bambulo de mi corazón, este libro es vuestro de cabo a rabo; mas no únicamente por tenerle como tema y contar su historia y la de su familia, sino también por ser suyo lo poco, o lo poco y pico, que yo he puesto en él. Segunda dedicatoria. Dictada por el propio Bambulo: A todos los que llevan un ancla sobre su espalda (Las bambulisticas historias de Bambulo. Primeros pasos: 22).

19 Cf. asimismo García Landa, 1998: 317-318. 
El tono paródico ${ }^{20}$ de las memorias auténticas es insoslayable. De la misma forma, los títulos propuestos por el secretario, a muy pocos pasos del autor textual, son fieles al espíritu de la obra:

Primer libro. Los primeros pasos. Bambulo visita la biblioteca de su ciudad natal y aprende algo que no sabía (algo bastante importante, por cierto) (Las bambulisticas historias de Bambulo. Primeros pasos: 23).

\subsubsection{La perspectiva del narrador. La focalización}

Hemos mencionado anteriormente cómo el concepto de perspectiva o focalización no constituye una categoría del discurso sino del relato. Sin embargo, hemos optado por tratarlo en este momento porque consideramos que en la narrativa infantil es un aspecto esencial en la configuración del relato como texto y en la definición del concepto de narrador.

El concepto de punto de vista está vinculado al de percepción. De este modo lo definía Ortega y Gasset (1923: 102-103):

El error inveterado consistía en suponer que la realidad por sí misma, e independientemente del punto de vista que sobre ella se tuviera, tenía una fisonomía propia. Pensando así, claro está, toda visión de ella desde un punto de vista determinado no coincidiría con ese su aspecto absoluto y, por tanto, sería falsa. Pero es el caso que la realidad, como un paisaje, tiene infinitas perspectivas, todas ellas igualmente verídicas y auténticas. La sola perspectiva falsa es esa que pretende ser la única.

Ortega (1923: 155-158) además insiste en que la única forma de acceder al conocimiento de la realidad es a través de la apariencia que ésta ofrece a quien la contempla y la apariencia es una cualidad objetiva de lo real, aunque siempre es una cualidad relativa a quien la percibe.

La categoría de perspectiva o punto de vista aplicada al discurso literario se fundamenta, pues, en la epistemología del siglo XX. Es James (Garrido Domínguez, 1993: 124-125) uno de los primeros en recuperar esta categoría para el relato literario con el afán de erradicar a un narrador omnipresente. También los formalistas rusos (Tinianov, Vinogradov, Eichenbaum) (cf. García Berrio, 1973: 249) con su teorización sobre el Skaz recogieron la importancia de esta noción. Sin olvidar, en este senti-

20 Asimismo, en Memorias de una vaca, Atxaga utiliza parecidos resortes narrativos. 
do, la importancia de las aportaciones de teóricos como Ingarden (1931: 197-206), Lotman (1978), Uspensky (1973) y, sobre todo, de Bajtin (1989), que sostiene que la perspectiva del locutor es la responsable última del carácter polifónico del discurso narrativo. Asimismo, los narratólogos alemanes (Füger o Stanzel) (cf. Garrido Domínguez, 1993: 131) concedieron a la teorización sobre el punto de vista un lugar de honor en sus consideraciones. No obstante, es a los narratólogos franceses a quienes se atribuye el hecho de haber otorgado la madurez a la doctrina sobre el punto de vista en la narración literaria. Pouillon (1970), Todorov (1975) y, por supuesto, Genette (1989a) insisten en este aspecto hasta ofrecer, sobre todo el último, el cuerpo básico de la doctrina de la que parten los estudios posteriores. Los tres teóricos coinciden en que el concepto de perspectiva está directamente relacionado con el lugar - externo o interno- en el que se sitúa el sujeto perceptor y con la cantidad de información que este tiene a su disposición.

Genette (1989a: 245-252) opta por apartarse de los peligros de una terminología marcadamente visual y define el concepto que estamos estudiando como focalización, para distinguir entre el sujeto de la percepción (modo) y el de la enunciación (voz). De esta manera, el término focalización funciona como sinónimo de filtro informativo cuya mayor o menor abertura depende del lugar en el que se sitúa el foco perceptor. Así, se distingue entre relatos con focalización cero (relatos no focalizados en los que el narrador no está sujeto a ninguna restricción en el ámbito del saber), relatos con focalización interna (relatos en los que el punto de observación se sitúa en el interior del personaje para percibir el universo representado a través de sus ojos) y narraciones con focalización externa (narraciones en las que el narrador está sujeto a mayores restricciones por su posición externa). Sin duda, la teoría de Genette, a pesar de las críticas recibidas, ${ }^{21}$ ha sido la que mayor potencial explicativo ha presentado al acercarse al discurso literario y será la que apliquemos al estudio de la focalización en el ámbito del discurso narrativo literario dirigido a los niños, recordando, eso sí, que la focalización en un relato no tiene por qué ser fija sino que puede variar en el transcurso del mismo.

21 La teoría de Genette sobre la focalización y sus tipos suscitó reacciones polémicas respecto del propio concepto y de sus modalidades. Entre ellas cabe destacar las de Bal (1985: 108), quien distingue entre sujeto focalizador y objeto focalizado y extiende el papel de focalizador al personaje, y Vitoux (1982: 359-362) y Rimmon-Kenan (1983: 74). 
La focalización se muestra como uno de los rasgos más difíciles de interpretar en lo que concierne al discurso narrativo infantil.

No hablaremos aquí de estadísticas sino de tendencias que se observan en el mercado a partir de los años ochenta y que se consolidan en los años noventa, para dar paso al siglo XXI. Por una parte, la focalización cero o falta de focalización aparece en las obras que, de alguna forma, se basan en un hipotexto de tipo tradicional proclive en las primeras edades al juego literario. Así relatos no focalizados como El cartero simpático, de los hermanos Ahlberg; Rastro de Dios, de Del Amo; La reina calva, de Company; Cuentos en verso para niños perversos, o ; Qué asco de bichos!, de Dahl; La larga siesta de papá, de Farias; La escoba de la bruja, de Asensio y Company; Te quiero, Valero, de Lalana; El lobo feroz o Pelotieso y Ricitos de Oro, de Monreal y Lalana, por citar algunos ejemplos, se desarrollan a través del juego metaliterario que implica por parte del destinatario el conocimiento del hipotexto tradicional para dar lugar a versiones desmitificadoras y humorísticas en gran número de casos. La falta de focalización en estas obras es exigida por la focalización inherente al hipotexto que funciona como texto subyacente. De este modo, obras como El cartero simpático, La reina calva, El lobo feroz, Pelotieso y Ricitos de Oro, Cuentos en verso para niños perversos o ; Qué asco de bichos! se basan en el conocimiento de cuentos populares del tipo de Caperucita Roja, Jack y las habichuelas mágicas, Ricitos de Oro y los tres ositos, Los tres cerditos o simplemente, como ocurre en ;Qué asco de bichos!, en toda la tradición de cuentos de animales. La focalización, pues, en estos textos, viene definida por el sustrato en el que se basan los diferentes relatos. Además, en estas versiones el narrador interviene cuando lo cree oportuno, desvelando sus conocimientos sin ninguna constricción proveniente de la focalización.

$$
\begin{aligned}
& \text { Cuando murió la madre de Blanquita } \\
& \text { dijo su padre, el Rey: «Esto me irrita. } \\
& \text { ¿Qué cosa tan pesada y tan latosa! } \\
& \text { Ahora tendré que dar con otra esposa...» } \\
& \text { —es, por lo visto, un lío del demonio } \\
& \text { para un Rey componer su matrimonio-. }
\end{aligned}
$$
versos: 13$)$.

(Dahl, Blancanieves y los siete enanos, en Cuentos en verso para niños per- 
La focalización cero aparece, pues, en relatos que presentan una vinculación a la narrativa de carácter tradicional. No queremos decir con esto que constituya una regla sin excepciones sino que es una tendencia general de la narrativa del último cuarto del siglo XX. Optando además por esta falta de focalización, el receptor adquiere una posición distanciada respecto de lo que el relato expone.

La focalización externa es un tipo de focalización bastante frecuente en la narrativa infantil de finales del XX y principios del XXI. Obras como ¿Qué risa de huesos!, de los hermanos Ahlberg; 'Papá!, de Corentin; Sapo y Sepo, inseparables, Días con Sapo y Sepo, y Sapo y Sepo, un año entero, de Lobel; ;Ahora no, Fernando! y No quiero el osito, de Mckee; Tú y yo, osito, de Waddell y Firth; iJulieta, estáte quieta!, de Wells; Barquichuelo de papel, de Puncel y López; u Osito y La visita de Osito, de Minarik, constituyen ejemplos de este tipo de focalización. Todos ellos, los que acabamos de mencionar, corresponden a álbumes o libros en los que la imagen es altamente significativa. La focalización externa supone que el narrador sólo cuenta aquello que hacen y dicen los personajes sin ahondar en lo que ellos piensan o sienten. ¿Por qué aparece este tipo de perspectiva en las obras dedicadas a los más pequeños? Colomer (1998: 266) justifica su presencia aludiendo al distanciamiento humorístico en temas de especial dureza, por una parte, y a la accesibilidad del texto. La focalización externa en el relato supone una presencia continua del diálogo en estilo directo, muy pocas descripciones y una falta de intromisión del narrador en el fondo de los personajes. Estos sólo se dan a conocer por lo que dicen y por lo que hacen. La narración es, por tanto, muy ágil y rápida, sin apenas pausas. En algunos de los ejemplos propuestos dentro del corpus que hemos seleccionado, la focalización externa reduce las narraciones a un diálogo rápido muy cercano al género dramático o cinematográfico en el que el receptor, ayudado por el código de la imagen, se convierte en un mero espectador de la historia, muy cercana, por otra parte, a la dinámica de las viñetas que van marcando el desarrollo del texto y desempeñan el papel de guía de lectura. Así ocurre en algunos cuentos de los que forman parte del libro titulado Osito, de E. Minarik. Sirva como ejemplo La sopa de cumpleaños, relato en el que, a través de la estructura propia del cuento de nunca acabar, el narrador va presentando a los diferentes personajes que acuden a la fiesta de cumpleaños del protagonista, que se ve obligado a preparar él mismo la sopa de cumpleaños ante la imprevista 
ausencia de su madre. El relato concluye con la llegada de ésta con una tarta para homenajear a Osito.

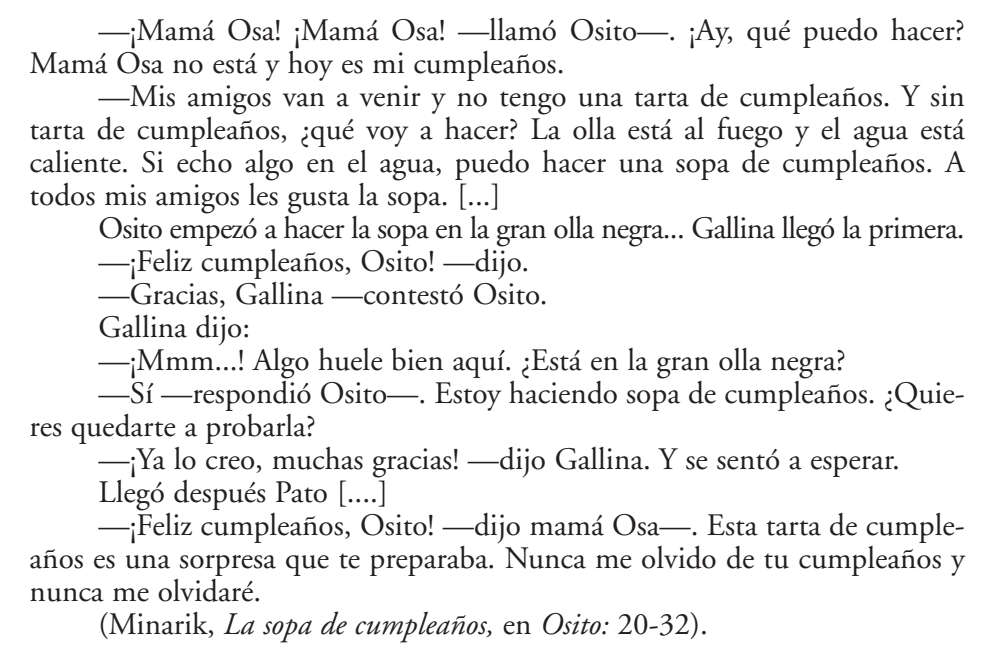

La recurrencia de las situaciones y el final totalmente cerrado, además de las ilustraciones que desempeñan la función de guía en la lectura del texto, facilitan el acceso del receptor a las claves de lectura de esta historia lineal.

La focalización externa se presenta en otro tipo de relatos en los que las claves de la interpretación del texto no residen en el propio texto sino que vienen facilitadas por la imagen. En estos casos, se trata sobre todo de álbumes, la ilustración constituye un elemento inexcusable para confirmar o rechazar las hipótesis o inferencias que el lector va realizando. Ésta es la técnica que utiliza ¡Papá!, de Corentin. En este álbum el narrador opta por presentar desde el texto dos historias casi idénticas con muy pocas variaciones:

En la cama, se lee. Pero también se duerme. ¡Buenas noches! Pero de repente... ¿Eh? ¿Qué? ¿Qué es eso? ¡Papá! «¡Papá! ¡Papá! ¡Hay un monstruo en mi cama!» «Tranquilízate! ¡Has tenido una pesadilla, eso es todo! Ven, vamos a ver a mamá. Está en el salón con unos amigos». «¿Qué le pasa a este hombrecito?», se extraña uno de los invitados. "Ha tenido una pesadilla», dice papá. "Ven, vamos a dormir. Da las buenas noches a todo el mundo», dice mamá. «¿Y sabes por qué has tenido una pesadilla, más que bobo? Porque has comido demasiada tarta de patas de ciempiés. ¡Eso es lo que pasa!» «¿Te has lavado los dientes? ¡Bien! ¿Has hecho pipí? ¡Así me gusta! Venga, pichoncito, a dormir» (Corentin, jPapá!: 7-17). 
Este es el texto que se vuelve a repetir en la segunda parte de la historia con una variación relevante: la "tarta de ciempiés», destacada en negrita en el texto, se convierte posteriormente en «tarta de manzana». Es la única clave textual que se ofrece al receptor para que este infiera que el suceso ocurre a dos personajes diferentes —el monstruo y el niño- La ilustración camina por el mismo sendero que el texto y desarrolla dos veces la misma historia con personajes diferentes que al final se encuentran y llegan a una solución común. La imagen constituye el pilar en el que se basa la obra en cuanto a su interpretación. Aun así, el receptor de esta obra debe colaborar en la interpretación última de ella, debe construir su significado a partir de las claves que texto e imagen ofrecen de forma conjunta. En ejemplos como el que hemos expuesto, la ilustración se mueve en la misma línea de sugerencia ambigua que el texto. La ilustración dirige pero no mediatiza y la obra se convierte en un cúmulo de sugerencias al albur del receptor. ${ }^{22}$ Una gran parte de los ejemplos de focalización externa pertenece a álbumes o a libros ilustrados. Como ya se ha señalado, el álbum ilustrado está sujeto a una recepción no demasiado definida cronológicamente, de tal manera que se le supone un destinatario natural como el que corresponde a los prelectores y a los primeros lectores y, además, un destinatario sin edad como consecuencia del atractivo que se desprende de la conjunción, en muchas ocasiones experimental, de los diferentes códigos. El narrador cuenta lo que ve sin profundizar en los sentimientos de los personajes, sin opinar sobre lo que está sucediendo en las imágenes. La historia da la impresión de contarse sola, únicamente el autor textual dispo-

22 Con el ánimo de comprobar las posibilidades que ofrece esta obra en su interpretación, se llevó a cabo la lectura apoyada en las imágenes de este libro en dos aulas, una de $3 .^{\circ}$ de educación infantil y otra de $10^{\circ}$ educación primaria, es decir, niños de 5, 6 y 7 años. Las interpretaciones de la obra han sido diversas dentro de las diferentes claves que ofrece la obra. Las más significativas son las siguientes: 1) el monstruo tiene miedo del niño y el niño tiene miedo del monstruo; 2) los monstruos tienen papás como los niños; 3) el niño y el monstruo se hacen amigos y comparten el osito en la cama.

Por otra parte, se comentó el libro en el transcurso de una optativa del plan de estudios de la Diplomatura de Magisterio denominada Narrativa Infantil y las interpretaciones fueron también muy diversas, esta vez por parte de los adultos mediadores, aunque todos coincidieron en que la finalidad de la obra era conjurar el miedo de los niños a la oscuridad y a la soledad. Se discutieron sugerencias de la historia en la línea de la tolerancia, de respetar a los que son diferentes, de preservar los miedos infantiles como una forma de reivindicar la especificidad de la infancia e incluso se trabajó la sugerencia del concepto de percepción: un niño le es tan extraño a un monstruo como el monstruo lo es para el niño. 
ne la organización de la narración a través de la insistencia recurrente y deja al lector que recoja las sugerencias y las incorpore a su propia experiencia. Quizá el receptor que todavía no posee mayor enciclopedia (Eco, 1987) que la cedida por la tradición oral y popular constituya un destinatario idóneo para el juego experimental en el que la sugerencia queda en la obra en espera de que alguien la recoja. Por otra parte, si tenemos en cuenta que el acceso del niño a este tipo de libros se realiza con la colaboración del adulto, es de suponer que su lectura, en el caso de los prelectores, consista en la visualización de imágenes y en la explicación de las propuestas de las mismas. Este tipo de obras se acerca sobremanera al campo de la experimentalidad basándose en el poder sugeridor de la imagen, dejando líneas abiertas en la interpretación de la obra y prescindiendo, al menos aparentemente, del direccionismo propio de la focalización interna o de la falta de focalización.

A pesar de que la conjunción de texto e imagen muestre las claves de interpretación de la obra, la colaboración solicitada al lector dista de la que se requiere en otro tipo de relatos mediatizado por la presencia de un narrador que dirige la percepción del destinatario. La razón por la que esto se produce en la narrativa destinada, con reservas, a los primeros lectores no radica, pues, en el hecho de facilitar el acceso al texto escrito sino en la presencia de un narrador menos preocupado por una línea argumental explícita, con mayor libertad para jugar con los significados y confiado en la mediación del adulto quien, de este modo, pasa a formar parte de la estrategia pergeñada por la obra. En la misma línea de experimentalidad se encontraría No quiero el osito, de McKee.

La focalización externa no sólo se limita a los álbumes ilustrados sino que también se encuentra en narraciones, destinadas asimismo a los primeros lectores, en las que la imagen ya no desempeña un papel tan destacado sino que más bien acompaña al texto ofreciendo informaciones complementarias en lo que hemos denominado libro ilustrado. En este tipo de narraciones, la focalización externa implica mayores dificultades en la interpretación. Las historias se presentan a través del diálogo y el narrador cuenta únicamente lo que sucede, sin ninguna intromisión más. Sin embargo, no se trata de historias basadas en el hipotexto popular sino que son sucesos que caminan por el sendero del distanciamiento humorístico a través del desarrollo de la comicidad situacional. Son pequeñas historias que desarrollan situaciones accesibles al destinatario. Cualquiera de los 
relatos que pertenecen a los libros protagonizados por Sapo y Sepo de Lobel puede servir para ilustrar este tipo de narración. En estos relatos predomina la focalización externa que contribuye a dar a la narración el aspecto de una sucesión rápida de diálogos. Así, en el caso de Colina abajo, Sapo intenta enseñar sin éxito a Sepo lo bonito y divertido que es el invierno. Después de quedarse solo en el trineo y acabar chocando contra un árbol, Sepo se enfada y se va:

Sapo llegó corriendo colina abajo. Sacó a Sepo de la nieve.

-Lo he visto todo - dijo Sapo.

Lo hiciste muy bien tú solo.

-No es verdad — dijo Sepo.

Pero hay una cosa que puedo hacer yo solo.

—:Cuál? - preguntó Sapo.

- Puedo irme a casa — dijo Sepo-. Quizá el invierno sea hermoso pero la cama es mucho mejor (Colina abajo, en Sapo y Sepo, un año entero: 18).

La ilustración en estos relatos complementa la información obtenida a través del texto. ¿Qué claves, pues, se ofrecen para que el lector interprete el sentido de la historia? Creemos que la interpretación del texto se basa en la presentación recurrente de unos personajes caracterizados esquemáticamente a partir de la imagen y de sus actos: Sapo siempre es el que toma la iniciativa ante cualquier situación, el más activo, y Sepo es el más perezoso e ingenuo. Los personajes reaccionan siempre de acuerdo con el carácter marcado tal como se muestra en Las pastas o El jardin, de Sapo y Sepo, inseparables, o Solo, de Días con Sapo y Sepo, por citar algunos ejemplos. La ironía presente en todos estos cuentos, que suponen un ensalzamiento de la amistad, es un recurso que atrae a los adultos y dificulta la interpretación última del receptor infantil. Una vez más, estimamos que cada una de las historias está basada en el poder de la sugerencia de los personajes y de las situaciones presentadas, acompañadas por las ilustraciones que contribuyen a cimentar la caracterización de los personajes y de las acciones. No olvidemos que cada una de las historias es iniciada por la presencia del título — responsabilidad del autor textual—, que contribuye a centrar la narración. La comicidad para los más pequeños viene suscitada por la confrontación de los dos personajes y por las ingenuas torpezas, todas ellas situacionales, cometidas por Sepo, que son las que, al fin y a la postre, desencadenan el nudo de la historia y su posterior resolución. 
Como hemos comprobado, pues, en este tipo de historia no sirve justificar la presencia de la focalización externa por razones de simplicidad y rapidez en la narración, sino que más bien la presencia de este tipo de perspectiva denota una confianza en el poder sugeridor de la obra y en la capacidad del lector de inferir interpretaciones no excesivamente dirigidas. ¿Nos encontramos ante el doble destinatario que, en opinión de críticos como Shavit (1986) y Wall (1991), define la especificidad de la literatura infantil? Creemos que sí. Según Shavit (1986), el fenómeno del doble destinatario constituye el principal motor de innovación de la literatura infantil y en este sentido interpretamos la presencia en nuestro corpus de obras como las que hemos expuesto.

A partir de los ocho años la presencia de la focalización externa se reduce notablemente, quizá por el hecho de que el receptor con una mayor enciclopedia va buscando en este momento líneas argumentales más complejas y menos sugerentes. Además, los autores parecen estar más preocupados por conseguir que el niño se identifique con los protagonistas, niños en su mayor parte (cf. Gómez del Manzano, 1987), y comparta con ellos su visión del mundo.

La focalización interna, además de estar en las obras con un narrador autodiegético, posee una presencia significativa en las obras que utilizan un narrador heterodiegético y que se dirigen a lectores mayores de ocho años. Ello no obsta para que tal focalización aparezca en obras con narradores heterodiegéticos dirigidas a destinatarios menores de ocho años, tal como ocurre en Perro y gato, de Alcántara y Gusti, en Munia y el cocolilo naranja, de Balzola, o en Yo las quería, de Martínez i Vendrell y Solé Vendrell.

Obras como Elvis Karlsson, de Gripe; Los apuros de un dibujante de historietas, de Farias; o Ramona empieza el curso, de Cleary, entre otras, son ejemplos del narrador heterodiegético focalizado en el protagonista.

No podemos afirmar, no obstante, que la focalización interna sea la predominante, aunque constituya una tendencia muy sólida. Lo que interesa en estas narraciones no es tanto lo que se cuenta sino la perspectiva desde la que se cuenta. Si seguimos el criterio que propone Stanzel, ${ }^{23}$ reco-

23 Este crítico (1984: 5) propone que en cada una de las situaciones básicas — primera persona, autorial, actorial — domina una determinada categoría: la voz, la perspectiva y el modo. Cit. por García Landa, 1998: 315. 
gido y puntualizado a su vez por García Landa (1998: 315), podemos intuir que en la narrativa en primera persona se motiva la narración y, subordinada a ella, la perspectiva; en cambio, en una narración heterodiegética lo que se motiva es la perspectiva. Así la potenciación de la perspectiva es clara en fragmentos como los que se ofrecen a continuación:

Elvis sabe que él es el origen de todas las preocupaciones de mamá. Él no ha salido como ella esperaba. En el salón sobre el tocadiscos, hay una fotografía de un cantante, tiene el pelo fuerte y negro cayendo en bucles. Mamá tiene muchos discos de él y los pone muchas veces. Uno no tiene ni idea de lo que canta, porque canta en inglés, pero lo hace muy fuerte. Algunas veces mamá hasta baila con su música. Cuando está contenta y recuerda otros tiempos, antes de casarse. Cuando él era el ídolo al que ella admiraba.

El ídolo se llama Elvis, y por esa razón él también se llama Elvis, para que se pareciera al auténtico Elvis de la fotografía. Pero no resultó así. Su pelo es castaño y tieso como un cepillo. Además tiene la voz ronca y no canta nunca. O sea, que es lógico que mamá tenga preocupaciones.

Otro de los problemas es que haya nacido niña, las niñas son más tranquilas y se les puede hacer vestidos, pero a los niños no vale la pena hacerles nada. Y como además mamá no va a tener más hijos no va a poder conseguir una niña, ya tiene a Elvis. Otra cosa buena de las niñas es que son más amables y más fáciles de educar, por lo menos eso es lo que dicen las amigas del teléfono.

Muchas personas tienen teléfonos blancos, pero el de ellos es negro, a lo mejor porque mamá le cuenta tantas preocupaciones y problemas. Es un aparato de tristezas. Elvis también sabe que es desobediente, terrible y muchas cosas más. El ser así también es una desgracia para él, pero parece que nadie se para a pensarlo (Gripe, Elvis Karlsson: 17).

Ramona miró a la señora Kemp, que sonrió y siguió haciendo ganchillo. ¿Por qué Ramona tenía que jugar con Guillermina y Bea no? Porque era más pequeña. Por eso. Ramona estaba deseperada ante semejante injusticia. Como era más pequeña, siempre tenía que hacer cosas que no quería hacer: irse a la cama antes, ponerse la ropa que se le había quedado pequeña a Bea y que su madre le había guardado, ir a coger cosas que estaban lejos, porque tenía las piernas más jóvenes y porque Bea siempre estaba haciendo deberes. Ahora tenía que llevarse bien con Guillermina — su familia entera dependía de elloy Bea no (Cleary, Ramona empieza el curso: 40).

Quizás con demasiada frecuencia Marta siente ganas de llorar; tiene bien ganada fama de llorona. Pero los demás no se dan cuenta de las sutiles diferencias de sus llantos, que no siempre son iguales, aunque puedan parecerlo. Y si lo parecen, es porque siempre el río incontenible de las lágrimas que pugnan por salir de sus ojos, color de miel, quizás no lleguen a darles paso a todas (Martínez i Vendrell y Solé Vendrell, Yo las quería: 7).

No es tan importante lo que el narrador cuenta sino la perspectiva desde la que contempla el mundo. De este modo, en narraciones que 
optan por la primera persona que focaliza el relato internamente, lo que en realidad importa es el suceso en detrimento de la potencialización de la perspectiva. Obras como Fantasmas de día, de Baquedano, o Las brujas, de Dahl, pueden ilustrar nuestra afirmación.

Yo mismo tuve dos encuentros distintos con brujas antes de cumplir los ocho años. Del primero escapé sin daño, pero en la segunda ocasión no tuve tanta suerte. Me sucedieron cosas que seguramente te harán gritar cuando las leas. No puedo remediarlo. Hay que contar la verdad. El hecho de que aún esté aquí y pueda contártelo (por muy raro que sea mi aspecto) se debe enteramente a mi maravillosa abuela (Dahl, Las brujas: 16).

Vine al mundo en otoño.

Nadie me preguntó si quería nacer o si prefería quedarme en ese lugar sin nombre, pero que seguramente existe. Es como una esfera, llena de oportunidades, parecida al bombo de la lotería. De pronto sale tu bola y no sabes si eres el premio gordo, el segundo, el tercero, o la pedrea, con la diferencia de que la lotería termina en cuanto la bola cae en el cesto, mientras la vida empieza justo en ese momento. Una gran aventura, si puedo expresarme como los mayores. Hasta ahora he tenido tanto trabajo que me ha sido imposible poner en orden mis memorias. A los nueve meses que acabo de cumplir, los niños empiezan a ser algo. No quiero perder ni un minuto de mi tiempo y voy a relatar lo vivido (Kurtz, Veva: 11).

No se trata, pensamos, de vincular únicamente la focalización interna en tercera persona a los conflictos externos (Colomer, 1998: 262) sino de justificarla a tavés de la potenciación de la perspectiva en detrimento de lo que el narrador relata; mientras que en la narración en primera persona con focalización interna prima el suceso sobre la perspectiva. Además, coincide en algunas obras la presencia de la primera persona focalizada internamente con la utilización del humor como elemento distanciador. Este hecho viene a corroborar nuestra hipótesis de que tanto en una focalización como en otra, tanto en la utilización de la primera persona como en la de la tercera, los narradores se distancian de aquello que cuentan. En el caso de la narración en primera persona focalizada internamente, es la perspectiva humorística la que contribuye a mitigar la dureza de algunas de las situaciones narradas, como ocurre en obras del tipo de El pequeño Nicolás, de Goscinny y Sempé o en Manolito Gafotas, de Lindo; en el caso de la narración en tercera persona focalizada actorialmente, es la utilización de la tercera persona la que distancia al receptor de la obra de los conflictos que en ella se exponen. 
No hay que olvidar que uno de los caminos por los que en la actualidad ha transcurrido la narrativa infantil es la psicologización de los conflictos, ${ }^{24}$ lo cual supone que la focalización es uno de los aspectos que deben ser tenidos en cuenta a la hora de analizar la cualidad del narrador en el discurso literario narrativo infantil. Tanto en la focalización externa como en la interna ${ }^{25}$ es relevante el factor del distanciamiento, para provocar que el lector se aleje, en la medida de lo posible, de aquello que se cuenta. ¿Una vez más aparece la protección del destinatario? Posiblemente sí. Además, la focalización interna redunda en el efecto de verosimilitud tan solicitado en la narrativa infantil de los últimos tiempos y en un narrador poco fiable que cuenta los hechos desde su perspectiva.

\subsubsection{El momento en el que se narra}

Contribuye a caracterizar al narrador el momento en el que este narra la acción. No nos referimos a la fecha en la que se escribe que, desde luego es importante, sino a la ubicación temporal del narrador respecto de lo narrado. Genette (1989a: 279-283; 1998: 54-57) distingue cuatro posibilidades: ulterior (posición de la narración en el pasado), anterior (relato predictivo), simultánea (relato en presente contemporáneo de la acción) e intercalada (entre los momentos de la acción).

La voz ulterior es, sin duda, la más frecuente en el tipo de discurso que estamos analizando. La utilización del tiempo pasado implica irremediablemente la posición ulterior del narrador. ${ }^{26}$ En lo que concierne a la narración en primera persona, autodiegética, la ulterioridad produce un efecto muy cercano a la omnisciencia, puesto que el narrador conoce la sucesión de los hechos y sabe mucho más que el personaje protagonista que, al fin y a la postre, es el mismo en momentos temporales diferentes:

24 Cf. Colomer, 1998: 222-232; 1999: 126-129.

25 No estudiamos la focalización múltiple puesto que sólo la hemos encontrado reflejada en La abuela, de Härtling, y i Que me parta un rayo!, de P. Barrena. Tanto en una obra como en otra, las perspectivas de los personajes protagonistas se van alternando para dar lugar al lector a contemplar la historia desde la perspectiva de los diferentes personajes.

26 La utilización del pretérito como signo inequívoco de ulterioridad no es una apreciación unánime. Hay autores (Hamburger, Barthes) que han defendido la vinculación del pretérito a la ficción, tal como expone y discute Genette en su Nuevo discurso del relato (1998: 54-55). 
Una nueva luz temblaba en sus pupilas. Sus ojos fríos, tan azules, se volvieron cálidos. Incluso al mirarme a mí lo hacía con ternura no fingida. El tiempo era hermosísimo y me decidí a decir "papá» y «mamá» sin tartamudear. $\mathrm{Y}$ otras muchas cosas. Lo tomaron bien, claro que extremé las precauciones para no preocupar a los papás.

Por supuesto nadie se extrañó de que empezara a corretear por la casa. Había precedentes (Kurtz, Veva: 104).

No es ajeno en estas narraciones el desdoblamiento entre el yo narrador y el yo personaje, de tal modo que el relato está focalizado en el yo personaje, lo cual implica un alejamiento del efecto de omnisciencia:

Estaba convencido de que no me negaría una rebanada de pan con mermelada cuando se lo pidiera al día siguiente, ni al otro, ni al otro... ¡Y qué buena mermelada hace!

Por otra parte, Aniceto estaba muy nervioso. Teníamos claro que hizo como si no nos viera cuando lo encontramos robando las nueces y que ahora estaba asustado (Baquedano, Fantasmas de día: 91).

Ahora bien, aunque la voz ulterior sea la más utilizada tal como ocurre en el érase una vez que se era, ${ }^{27}$ propio de la narrativa tradicional e hipotexto de bastantes obras de la narrativa infantil actual, no es desconocida en el ámbito que nos concierne la voz simultánea. En las obras de los últimos años del siglo XX y en las de principios del XXI, la narración simultánea aparece con cierta asiduidad ofreciendo al relato un aspecto de inmediatez propio del reportaje. Genette (1989: 276) observa que este recurso puede funcionar en direcciones opuestas: o bien potencia la historia sobre el discurso - relatos objetalistas_-, o bien el discurso acaba por borrar la historia. En el discurso narrativo infantil, creemos, se oscila entre estos extremos sin atrevernos a afirmar la preponderancia de uno sobre otro. Obras como iJulieta, estáte quieta!, de Wells; Osito, de Minarik; Los osos de Ni-se-sabe, de Varvasovszky; El cartero simpático, de los hermanos Ahlberg; el Libro de las M'Alicias, de Obiols; ;Papá!, de Corentin; Cuando era peque$\tilde{n} a$ (Las nuevas historias de la bruja aburrida), de Capdevila; Yo las quería, de Martínez i Vendrell y Solé Vendrell; o La torre de Londres, de Saunders, constituyen ejemplos de la narración simultánea, además, claro está, de todos los libros-juego reseñados en el corpus seleccionado. En Diecisiete

27 Referencias a la significación de este pretérito se encuentran en estudios como los de Szertics, 1967: 69; Gili Gaya, 1972: 27; Hernández, 1973: 169; Rojo, 1974: 118; Gilman, 1981: 111; Durand, 1982: 255; o López Tamés, 1985: 101-104. 
cuentos y dos pingüinos, de Nesquens, varias de las historias utilizan la voz simultánea con la idea de solicitar la colaboración del receptor en la generación de significados y en la línea de presentar una realidad en constante evolución, como corresponde a la posmodernidad. Así pues, los ejemplos de voz simultánea no son aislados sino que comienzan a ser significativos (Colomer, 1998: 262). En el análisis que hemos realizado de las narraciones que presentan este tipo de voz, hemos llegado a encontrar algunos factores comunes. En primer lugar, casi todas ellas teóricamente presentan un narrador heterodiegético; sin embargo, el hecho de que el narrador se encuentre en la posición de contemporáneo lo convierte en una especie de testigo e introduce en el relato una dosis de homodiegeticidad. De la misma forma, en relatos heterodiegéticos narrados en pasado pero encabezados o terminados en presente se produce la misma introducción de un carácter parcialmente homodiegético, como ocurre en Las brujas, de Dahl, o en La Cenicienta (Cuentos en verso para niños perversos), del mismo autor. Con la creación de esta sensación de cercanía del narrador respecto de lo que se cuenta, se contribuye asimismo a aproximar al receptor. De igual manera, uno de los narradores de El grito de la grulla utiliza la voz simultánea, alejándose relativamente de la ominisciencia y solicitando la colaboración de un receptor que debe construir el mundo de ficción con las informaciones que le procuran las diferentes fuentes.

Como no podía ser de otra manera, en todas las obras mencionadas más arriba como ejemplo de voz simultánea, la ilustración desempeña un papel fundamental en la construcción de la narración. Se produce, en este sentido, una complementariedad entre texto e imagen, una de las vías por las que transcurre el discurso infantil de nuestros días. El uso del presente en la narración acentúa esta colaboración entre los dos códigos, de tal modo que se produce a veces la sensación de que la imagen es una viñeta a la que el texto añade ciertas informaciones, muy en la línea del receptor actual acostumbrado al discurso propio de los medios audiovisuales. Así, en El libro que tenía un agujero, el texto en presente se apoya en la imagen casi a manera de cómic. Y cómo no recordar a este respecto obras como Ahora no, Fernando, de McKee, o ¡Qué risa de huesos!, de los hermanos Ahlberg, anteriores en el tiempo e innovadores en muchos aspectos.

En bastantes casos, la narración simultánea coincide con la focalización externa, lo cual nos conduce una vez más al camino de la experimentalidad — que en el siglo XXI ya no lo es tanto-, muy propia de la 
narrativa infantil de los últimos años, narrativa en la que el receptor tiene que colaborar en un juego constructivo compartido.

Al pequeño Salustiano le dan de cenar temprano. Y Papá juega con Flor porque es la hermana mayor. Salustiano debe echar su aire después de cenar. Y, mientras, ¿qué hace Julieta? Esperar y estarse quieta... «iPues ya no me da la gana!» y da un golpe en la ventana. Organiza en un momento un ataque violento: Tira los dulces de Flor, pega un portazo de horror... Y Papá y Mamá: "Julieta, por favor, estáte quieta...» (Wells, iJulieta, estáte quieta!: 6-11).

Alicia se cansa de estar junto al ordenador, sin tener nada que hacer, y decide salir; pero no sabe qué ponerse. Abre el frigorífico. En su interior hay una cazuela con conejo y, en un plato blanco, una oreja izquierda con un pendiente de oro en forma de estrella. Nada más. De pronto recuerda que anoche no sacó nada para que se descongelara. Su madre le dice que va bien vestida para salir con amigos. Pero ella insiste en que quiere cambiarse. Va a tener que pornerse todo congelado. ¡No importa! (Obiols, Libro de las M'Alicias: cap. 1).

Este verano, tus padres y tú os vais de viaje a Inglaterra. En Londres pasas unos días en casa de Rodney, el chico inglés con el que mantienes correspondencia. Rodney y su familia viven en un sitio muy especial en un apartamento construido dentro del recinto de la Torre de Londres (Saunders, La torre de Londres: 1).

En definitiva, tanto la voz simultánea, como la focalización externa son líneas características de las obras que han marcado los últimos años del siglo XX y los principios del siglo XXI, de tal modo que da la sensación de que la innovación del hasta ahora tradicional ámbito de la narrativa infantil se realiza a través del fomento de una confianza mayor en el receptor al que se le ofrecen discursos en los que tiene que colaborar, y al que se le aprecia una capacidad interpretativa apta para el juego experimental.

\subsubsection{La implicación del narrador}

Como hemos señalado anteriormente, el grado de implicación del narrador frente a lo narrado se relaciona con lo que Genette (1989: 308 y ss.) define como funciones testimonial e ideológica del narrador. Estas dos funciones, como afirma García Landa (1998: 299), son inherentes al narrador:

Estas tres últimas funciones - se refiere a las funciones comunicativa, testimonial e ideológica - son opcionales en el sentido de que algunos narradores las desempeñan deliberadamente y otros no. Sin embargo, toda narración contiene inevitablemente de modo implícito una orientación hacia el narratario o hacia la acción, y una ideología. 
En lo que concierne a las funciones testimonial e ideológica, el narrador puede optar por una neutralidad aséptica, propia del narrador cámara o por una implicación más o menos cercana al conflicto o a sus figuras. La primera posibilidad aparece en la narrativa infantil de la mano del narrador que focaliza externamente y utiliza el presente en el discurso. El narrador se muestra en estos casos distante y frío ante la historia que expone. Ello no implica que el discurso se encuentre desprovisto de ideología sino que la función ideológica es desempeñada por otra instancia discursiva como el autor textual o el propio autor. En este sentido, no estaría de más analizar las implicaciones ideológicas presentes en las ilustraciones que, como ya hemos señalado, suelen formar parte inexcusable de los relatos focalizados externamente. Obras como el Libro de las M'Alicias, de Obiols, reproducen la subversión de la infancia tanto desde el texto como desde la imagen que acompaña a cada uno de los fragmentos. El autor textual en estas ocasiones desempeña lo que se denomina función testimonial y, sobre todo, ideológica.

La segunda posibilidad de las señaladas, es decir, la del narrador que se implica en la acción, que la comenta o que se compromete de algún modo con los personajes es bastante común en el narrador propio de este tipo de discurso. La ideología debe, sin embargo, contemplarse en un contexto más general del que dibujan estas páginas. No obstante, podemos acercarnos a algunas de las líneas comunes de las que parten los narradores que se implican en el discurso.

En primer lugar, el discurso narrativo dirigido a los niños en los últimos años del siglo XX, tal como hemos expuesto en el apartado anterior, ha optado, como tendencia significativa, por presentar un narrador que focaliza internamente en el protagonista. A este narrador le interesa la cosmovisión del protagonista que en la mayor parte de los casos es un niño que se identifica con el receptor. ${ }^{28} \mathrm{~A}$ través de esta focalización el narrador se adentra en el protagonista-niño y en la visión del mundo que le rodea. En la línea de complacer a un lector que asiste a la aparición de una nueva constelación

28 Colomer (1998: 237) presenta los resultados del análisis de las obras que ha seleccionado como base de su trabajo:

Protagonistas humanos: 79,60. Infantiles: 56,71. Adultos: 30,85.

Protagonistas animales: 8,46

Protagonistas fantásticos: 11,94. 
de valores, el narrador de este tipo de discurso intentará adaptarse al nuevo receptor inmerso en una sociedad que defiende valores hasta ahora desconocidos, como la verbalización de los problemas y la anulación de algunas fronteras entre el mundo infantil y el adulto (Colomer, 1998: 109).

En una sociedad como la que se acaba de describir, el narrador, sobre todo a través de la focalización interna, va a potenciar la necesidad de salvaguardar los derechos del niño, en especial el derecho a la libertad y al placer. Se huye del didactismo explícito, propio de la literatura infantil desde sus orígenes, para dar paso a un narrador menos «adulto» que valore la autonomía de la infancia. Este narrador va a optar por diferentes posibilidades: adentrarse en la vía fantástica como ocurre en Matilda, de Dahl, o Harry Potter, de Rowling, caminar por la vía del realismo psicológico -Elvis Karlsson, de Gripe- o utilizar el humor como medio de distanciamiento - Manolito Gafotas, de Lindo-. El mundo infantil subraya su autonomía y las incoherencias que descubren en los comportamientos y actitudes de los adultos. Con esta finalidad, el narrador es en ocasiones el que lleva a cabo el discurso moral:

Ya es malo que haya padres que traten a los niños normales como postillas y juanetes, pero es mucho peor cuando el niño en cuestión es extraordinario, y con esto me refiero a cuando es sensible y brillante. Matilda era ambas cosas pero, sobre todo, brillante (Dahl, Matilda: 14).

Sin embargo, no es poco común el hecho de que el narrador, al enfrentarse al discurso moral, ceda su voz a algún personaje adulto. Así, en La historia de Ernesto es la madre la que desarrolla el discurso didáctico:

Sí que te amaban pero para hacer de padres no basta sólo con amar. Hacer de papá y mamá es, también, limpiarte los mocos, anudarte los cordones de los zapatos y sostenerte la mano cuando la caquita sale dura. Es ponerte supositorios si te duele la tripa o tienes fiebre (¿te acuerdas cuando tuviste paperas?). Y es llevarte a la escuela e irte a buscar. Es darte unos pequeños azotes y reñirte si te portas mal o haces travesuras (Company, La historia de Ernesto: 31-33).

En La abuela, de Härtling, el narrador cede la voz a la abuela para que exponga sus valorables experiencias:

Es raro que me inquiete todavía pensar en ella. En realidad no estaba mal. Y era una buena madre. Lo único que pasa es que lo hacía todo de forma diferente a la mía. No se preocupaba tanto del niño. Decía siempre que tenían 
que aprender a arreglárselas solos. Eso sí, pero hay que ayudarles. Así decía que lo hacía ella también. A mí me parecía que no. No nos entendíamos, es cierto. Me crispaba los nervios. Y yo a ella seguro que también (Härtling, La abuela: 28).

Como se podrá comprobar, sobre todo en el primer ejemplo, el discurso moral se hace demasiado explícito y, a pesar de idear estrategias que diluyan la presencia de ese didactismo que ha acompañado a la literatura infantil desde los comienzos, la finalidad docente queda al descubierto tal como ocurre en algunas de las obras que pertenecen a la corriente denominada psicoliteratura, línea a la que, por supuesto, pertenece La historia de Ernesto.

En todo caso, con la finalidad de que el discurso moral no resulte tan forzado no resulta extraño ceder la voz al protagonista infantil de tal forma que sea él mismo quien muestre sus reflexiones al receptor. De este modo ocurre en Fantasmas de día, de Baquedano; El pequeño Nicolás, de Goscinny; Manolito Gafotas, de Lindo; o Querida abuela, tu Susi, de Nöstlinger:

Mi padre parecía cada vez más enfadado. No sé por qué no me creía si yo casi nunca digo mentiras. Ya me veía todo el verano sin paga y sin salir de casa y, por si fuera poco, sin la bici del abuelo. Pero los mayores son extraños. Se olvidaron de nosotros y empezaron a agruparse alrededor de don Genaro, que parecía muy emocionado, y no hacía más que decir: «No nos hagamos ilusiones, es posible que no sea la nuestra... Pero ¿y si lo fuera?» (Baquedano, Fantasmas de día: 84-85).

Nos habría gustado quedarnos para ver a papá y al señor Blédurt divertirse y hacer el payaso; pero no pudimos, porque mamá nos llamó a merendar, y depués fuimos a mi cuarto a jugar con el tren eléctrico. Lo que yo no sabía es que a papá le gustase tanto jugar a cow-boys. Cuando bajamos, por la noche, el señor Blédurt se había marchado hacía un buen rato, pero papá seguía atado al árbol, gritando y haciendo muecas. lás: 24).

¡Es formidable saber divertirse así, uno solo! (Goscinny, El pequeño Nico-

La madre del Orejones mola un pegote porque está divorciada, y como se siente culpable nunca le levanta la mano al Orejones para que no se le haga más grande el trauma que le está curando la señorita Esperanza que es la psicóloga de mi colegio. Mi madre tampoco quiere que me coja traumas pero, como no está divorciada, me da de vez en cuando una colleja, que es su especialidad (Lindo, Manolito Gafotas: 9).

¡Imagínate abuela! La mamá de Paul nos pidió que no le contásemos nada al papá de Paul. Si se entera castigará a Paul tres días encerrado en su cuarto de hotel. ¡No le contamos nada, claro! Pero resulta gracioso que ellos dos le escondan cosas. ¿¿No te parece? (Nöstlinger, Querida abuela, tu Susi: 46-48). 
Una de las razones por las que el narrador autodiegético aparece en la narrativa infantil identificado con el protagonista-niño es la de intentar eliminar el excesivo didactismo tan propio de la literatura infantil.

Nos hemos detenido, en lo que concierne a la función ideológica, en la necesidad de los autores de reafirmar los valores propios de la infancia, de destacar su especificidad frente al mundo de los adultos y, para ello, hemos insistido en las estrategias retóricas utilizadas por el narrador para implicarse en la acción como son la focalización interna actorial, la cesión de la voz a un personaje adulto y la identificación del narrador con el protagonista-niño. Las tres estrategias, sobre todo la primera y la tercera, buscan no sólo conseguir que el receptor infantil se identifique con la cosmovisión reflejada sino también establecer lazos de unión con el adulto mediador que va a valorar el libro en su adecuación al público infantil. El adulto, de este modo, se ve reflejado en la narración a través de los ojos de la infancia. Ejemplos evidentes de esta duplicidad de recepción a la que tiende el narrador implicado en la acción aparecen en obras como $E l$ pequeño Nicolás, de Goscinny; Manolito Gafotas, de Lindo; Matilda, de Dahl; Elvis Karlsson, de Gripe; Ha sido el pequeño monstruo, de Cooper; o Las brujas, de Dahl, por citar algunos ejemplos.

Todo el mundo se había levantado y gritaba menos Clotario, que seguía llorando en su rincón, y Agnan, que se había ido al encerado y recitaba $L a$ zorra y el cuervo. La maestra, el inspector y el director gritaban: «Ya basta!». Nos lo pasamos bomba.

Cuando la cosa se paró y todos nos sentamos, el inspector sacó su pañuelo y se secó la cara, se llenó todo de tinta, y es una lástima que no tengamos derecho a reírnos, porque habrá que aguantarse hasta el recreo, y no va a ser muy fácil. El inspector se acercó a la maestra y le estrechó la mano.

- Cuenta usted con todas mis simpatías, señorita. Nunca hasta hoy, he comprendido hasta qué punto nuestra profesión es un sacerdocio. ¡Continúe! ¡Ánimo! ¡Muy bien!

Y se marchó a toda prisa con el director. Nosotros queremos mucho a nuestra maestra, pero ella ha sido realmente injusta. ¡Gracias a nosostros la han felicitado y nos ha castigado a todos sin salir! (Goscinny, El pequeño Nicolás: 43-44).

El hecho de que hayamos insistido en las estrategias del narrador actual para disfrazar las valoraciones morales no quiere decir que hayan dejado de existir los narradores tradicionales omniscientes que opinan frecuentemente sobre el desarrollo de la acción y sobre las acciones de los personajes. Este tipo de narrador sigue existiendo, tal como señala Colo- 
mer (1998: 292), en muchas de las obras seleccionadas como Charlie y la fábrica de chocolate, de Dahl, o El tragasueños, de Ende, por citar algunos ejemplos. Lo que hemos intentado reflejar es el hecho de que la introducción de comentarios por parte del narrador ha llevado a los autores a reflexionar sobre el peligro que supone decir en lugar de mostrar dejando que el significado emane de la acción, del relato y de su posterior configuración en el discurso. Los comentarios pueden convertir al narrador en un predicador que cierra el contenido del discurso en un tono didáctico, tal como le ha pasado al discurso infantil en los inicios de su andadura. Esto es lo que, con diferentes artificios, intentan evitar los narradores de finales del siglo XX. Pensamos, además, que ésta es una de las razones por las que se está extendiendo la presencia de la focalización externa en el discurso que nos ocupa, en la línea de abandonar las marcas propias de la literatura oral de gran influencia en la narrativa infantil, para dar paso a una literatura escrita permeable a las formas de experimentación moderna. En estos casos, la valoración moral, que no desaparece del discurso dirigido a los niños, es realizada por el autor textual. Obras como La carta de la señora González, de Lairla y Lartitegui, entienden que la explicitación es una de las características de las que es necesario huir para observar criterios de calidad literaria. Obras como Palabras de caramelo, o Besos del Sáhara, de Moure, o El grito de la grulla, de Alonso, constituyen ejemplos de una literatura comprometida con la realidad social sin necesidad de abusar de la «moralina» tan propia del discurso de otros tiempos.

La ideología de una obra no sólo es responsabilidad del narrador sino que se desprende también de los personajes elegidos, del transcurso de la acción, de los temas reflejados, etc. Nosotros sólo hemos analizado cuál es el papel que desempeña el narrador en el aspecto ideológico, uno de los más complejos en el ámbito de la literatura infantil.

En definitiva, el narrador sigue implicándose ideológicamente en un discurso que no acaba de caminar solo. Si en ocasiones se ha hablado de la posibilidad de la desaparición del narrador en el discurso que nos ocupa (Díaz-Plaja, 1998), por lo que hemos expuesto, se podrá comprobar cómo el narrador sigue dominando el discurso literario infantil, teniendo en cuenta además que la focalización constituye una estrategia retórica del narrador y como tal hay que entenderla. 


\subsection{El narratario}

En este apartado vamos a tratar de exponer todo lo relativo a una instancia del discurso que nos parece de vital importancia en la caracterización pragmática del discurso narrativo infantil. En primer lugar, vamos a definir cuál es el concepto de narratario del que partimos y posteriormente nos centraremos en el análisis de esta instancia en el ámbito que nos ocupa.

El narratario se define como el destinatario de los actos de habla realizados por el narrador. El narratario, en tanto que aparece como una figura independiente, se constituye como un personaje interno a la ficción. ${ }^{29} \mathrm{El}$ caso no marcado es su identificación con el lector textual y, por tanto, la ausencia en él de rasgos definitorios. Prince (cit. por García Landa, 1998: 385) expone la presencia de un "narratario grado cero» que satisfaría el mínimo de condiciones comunicativas para desempeñar adecuadamente su papel: conocer el idioma del narrador, ignorar la historia, saber llenar las presuposiciones del narrador, seguir el relato ordenadamente, etc.

Toda desviación del grado cero construirá la imagen de un narratario individualizado. El narratario no es una voz del texto y, por lo tanto, no se le puede conocer por lo que dice si el narrador no lo describe, sin embargo, su imagen emana de la estructura de la narración. El narratario no es accesible a través de un indicio propio, pero sí es accesible la imagen que el narrador tiene del narratario, a través de los elementos apelativos contenidos en la narración: pronombres de segunda persona o de primera del plural, tipo de lenguaje utilizado, estructura informativa del mensaje, etc. En suma, es el narrador el que ofrece la imagen del narratario, por lo tanto, la caracterización es indirecta y será fiable en tanto en cuanto el narrador lo sea.

El narratario puede constituirse a veces como una motivación de ciertas actitudes discursivas dirigidas al lector, puede solicitar posibles aclaraciones o asegurar la veracidad de las afirmaciones, tal como expone García Landa (1998: 387). De todos modos, la figura del narratario siempre existe como posición teórica en un discurso narrativo; su estatus puede identificarse con una mera convención retórica (cf. Prince, 1973: 187 y ss.) en 
narraciones que no presentan un interlocutor ficticio o llegar a la individualización extrema como instancia comunicativa. De este modo, puede asimilarse al propio narrador, a un personaje o incluso al protagonista de la narración.

El narratario asimismo desempeña un papel activo en la recepción del relato. Cuanto más personalizado esté, más activo se mostrará en el desarrollo del discurso. Cuanto menos personalizado se encuentre el narratario, se corre el riesgo de que este pierda sus rasgos diferenciadores y se confunda con el lector textual.

\subsubsection{El narratario en el discurso narrativo literario infantil}

Pocas veces se ha tratado con detalle la presencia del narratario en el discurso literario infantil. Colomer (1998: 291-298), cuando se acerca a este elemento del discurso, parte de la hipótesis de que el narratario podría desaparecer, puesto que se trata de una reminiscencia de la comunicación literaria oral, y la narrativa infantil actual debería tender a reflejar los recursos propios de un género de raigambre escrita.

Partimos de la consideración del narratario como una instancia enunciativa inherente al discurso: el narratario siempre existe ya sea como una mera convención retórica o como interlocutor ficticio individualizado. Intentaremos, pues, una clasificación de los narratarios que aperecen en el discurso que nos ocupa utilizando como criterios la identidad y el grado de conocimiento de la acción vinculado a la perspectiva.

Aunque el narratario, como hemos expuesto anteriormente, admite las mismas modalidades que el narrador, hemos optado por ofrecer una clasificación de esta instancia enunciativa utilizando como referencia únicamente los dos criterios expuestos más arriba, soslayando de este modo referencias - narratario único o múltiple, peronalidad fija o variable- que, en lo que respecta a la narrativa infantil, no nos han parecido significativas.

\subsubsection{La identidad del narratario}

Distintos son los grados de individualización en los que se muestra el narratario: desde los narratarios identificados con personajes de la historia, hasta los casos no marcados en que narratario y lector textual coinciden en casi todo menos en su posición estructural. 
El narratario individualizado que se identifica con un personaje de la historia suele coincidir con la presencia de un narrador intradiegético que se dirige a un personaje de la historia y que establece un puente entre esta y el lector textual. Ejemplos que ilustren esta modalidad pueden ser Historias de ratones, de Lobel, o No nos podemos dormir, de Stevenson. Tanto en un caso como en otro, los narratarios necesitan dormir y las historias que les cuenta el narrador cumplen la función de relajar al destinatario. Los narratarios se identifican con los hijos, en Historias de ratones, y los nietos del narrador, en No nos podemos dormir:

«Papá ya estamos todos en la cama» - dijeron los ratoncitos. «Anda, cuéntanos un cuento». «Mejor que eso» — dijo Papá. «Os contaré siete cuentos, uno para cada uno, si me prometéis dormiros en cuanto acabe.» «Sí, sí, nos dormiremos» - dijeron los ratoncitos. Y Papá empezó... (Lobel, Historias de ratones: 1 - 2)

-No nos podemos dormir — dijo Luisito.

— ¿Y eso? - dijo el abuelo- ¿ ¿Qué os pasa?

— Hace demasiado calor y hay demasiado silencio — dijo Ana Mary.

— Hay demasiado viento y demasiado ruido — dijo Luisito.

- Hay demasiada luz.

-Está muy oscuro.

-Me siento muy solo.

—Es que no nos podemos dormir — dijo Ana Mary.

—QQué raro! —dijo el abuelo—. A mí una vez me pasó lo mismo. Fue hace muchos años. Tendría yo vuestra edad.

(Stevenson, No nos podemos dormir: $1-3$ ).

El narratario justifica aquí la presencia de las historias que, por supuesto, se adaptan a él y a su necesidad de dormirse, lo cual implica que las historias sean recurrentes en su composición. El grado de individualización de este narratario viene dado por su identificación con los personajes de la historia, es decir, el receptor conoce sus características físicas y su relación con el narrador. Este narratario es muy propio de las obras dirigidas a los primeros lectores que responden a esquemas tradicionales.

Dentro de la narrativa dirigida a estos primeros lectores encontramos obras que se adentran en la vía experimental y renovadora a través del juego con las personalidades del narrador y del narratario, tal como ocurre en El cartero simpático, de los hermanos Ahlberg, obra en la que un cartero va repartiendo cartas a diferentes personajes provenientes de la narrativa tradicional: 
El cartero jovial, que está un poco mareado, se acerca a una extraña «abuela» que luce dientes muy largos. (Una abuela francamente sospechosa, ¿verdad?) ${ }^{30}$

La carta va dirigida... ;Ooooh!

Sr. D. Lobo M.

C/ o Cabaña de la Abuela

Los Avisperos

MÁS, MENOS Y MUCHOS ABOGADOS, S. A.

Edificio Mercurio, Calle del que Venga, Tfno. 12345

Estimado Sr. Lobo:

Le escribimos en nombre de nuestra clienta, la señorita Caperucita Roja, a propósito de su abuela. La señorita Caperucita Roja nos dice que está usted ocupando la cabaña de su abuela y se pone ropas sin el consentimiento de dicha señora.

Sírvase tomar buena nota de que si esta situación continúa avisaremos al Leñador Mayor y si es preciso a todos los hombres del rey.

Por otra parte, debemos informarle de que los Sres. Tres Cerditos, S. L., están firmemente resueltos a ponerle un pleito por daños y perjuicios. Su oferta de compartir las ganancias en un robo de coles o lechugas ha sido desestimada, y no le servirá de nada perseverar en su presunta actitud.

Suyo afmo.

H. Más.

En ocasiones, el narratario individualizado se muestra más activo en la elaboración de la historia, de tal modo que se convierte en un ayudante del narrador en la gestión de la historia. De esta manera se conducen el narratario de Los osos de Ni-se-sabe, de Varvasovszky. En esta obra, el narrador se imagina a un niño llamado Julián que es el receptor de la historia que está escribiendo. Julián le realiza constantemente puntualizaciones acerca de lo que está oyendo y, de este modo, resuelve las posibles ambigüedades, ayuda al receptor en su interpretación y se adelanta a este en muchas de sus consideraciones:

En este momento el niño me interrumpe. ¡Ah!, por cierto, se me olvidaba deciros que se llama Julián.

— Esto no es un cuento de verdad!

- ¿Y por qué, vamos a ver?

-Un cuento de verdad empezaría así: HABÍA UNA VEZ SIETE

OSOS BLANCOS QUE VIVÍAN EN LA ISLA DE NI-SE-SABE...

- ¿Siete? ¿Y por qué siete?

- Has dibujado siete, ¿̨no?

30 El narrador, puesto que se adentra en el juego metaliterario, realiza comentarios que ayudan al lector a gestionar la acción. Esto suele ocurrir en todas aquellas obras dirigidas al receptor infantil que se adentran en los caminos de la experimentalidad. 


\footnotetext{
—Es verdad. Uno por cada día de la semana. Lunes.

—Entonces ya sabemos sus nombres. El pequeño de la izquierda se llama

—De acuerdo — le digocon los días de la semana.

- ¿Y qué? Los siete osos blancos se llamarán así: Lunes, Martes, Miércoles, Jueves, Viernes, Sábado y Domingo (Varvasovszky, Los osos de Ni-se-sabe: 9-10).
}

El narratario, en este caso, plantea las cuestiones pertinentes para facilitar al narrador la organización de la historia y al lector la comprensión de esta última. Igualmente se mueve la presencia del narratario en Si quieres pasar miedo, de Sommer-Bodenburg. En dicha obra, el protagonista, Florián, está enfermo y solicita a sus padres y a su abuela que le cuenten historias para poder sobrellevar el aburrimiento. Florián, en su papel de narratario, formula continuas preguntas acerca de la realidad y la ficción:

— ¿Te ha gustado la historia? — preguntó.

- Sí — dijo Florián-. Pero, ¿te ha pasado de verdad?

Su padre sonrió.

-Tú querías oír una historia de miedo y yo te la he contado.

Florián pensaba cómo podría sacarle la verdad. las cuentas.

_Es cierto que ibas a repetir curso? Mamá dice siempre que haces bien

— iClaro! Harry me enseñó.

- Entonces, ¿existió Harry en realidad?

-Y... ¿Era un vampiro?

—Quizá... En todo caso, yo logré pasar de clase, que para mí era lo importante — contestó el padre y se levantó (Sommer-Bodenburg, Si quieres pasar miedo: 51-52).

Del mismo modo, Company en La historia de Ernesto coloca a Ernesto en la posición estructural del narratario para que el niño plantee, desde la perspectiva infantil, las diferentes cuestiones que pueden formularse en torno a esta situación:

Ernesto ha quedado pensativo. Luego, mirándola abiertamente, pregunta: - ¿Y aquellos señores no querían hacer todo esto por mí?

—No es que no quisieran — responde el padre—, es que no podían. Porque para tener un hijo no basta con tener dinero y una casa donde vivir. Es necesario disponer de tiempo y de la posibilidad de estar con él, de poderlo educar en un ambiente donde el hijo crezca feliz y seguro. Y también, vencer nuestros propios egoísmos de adultos. Y no es nada fácil, ¿¿sabes? A veces hay que renunciar a muchas cosas para ser padres. ¿Lo entiendes? (Company, La historia de Ernesto: 42-43). 
Este tipo de narratario suele ser muy común en el ámbito de lo que hemos denominado psicoliteratura puesto que ofrece las pautas necesarias para dar paso al discurso didáctico.

Narratario también individualizado, pero esta vez ajeno a la historia, es el propio de las narraciones epistolares. Así Nöstlinger en Querida abuela, tu Susi presenta este tipo de narratario como destinatario de las cartas que la protagonista escribe cada día a su abuela desde su lugar de vacaciones. El personaje de la abuela no se desarrolla puesto que sólo ocupa la posición estructural del narratario en el discurso, lo cual asemeja el contenido de la obra a un diario. La abuela, pues, adquiere los rasgos propios de un personaje tipo y el receptor sólo la conoce por lo que la protagonista dice de ella. Susi expone en sus cartas lo que le sorprende del mundo que la rodea buscando la aquiescencia de su abuela:

Tras la reconciliación, volvimos a pelearnos. Quería convencerme de que los niños A.A. eran tontos y de que no debía hablar más con ellos. ¡Entonces sí que me disparé! ¡Fue la puntilla! ¡Yo tengo que entender que él no me quiera sólo a mí, pero él no puede comprender que a mí me gusten otros, aparte de él! (Nöstlinger, Querida abuela, tu Susi: 97).

Encontramos el mismo procedimiento al final de cada capítulo en la obra De Victoria para Alejandro, de Molina.

Como hemos podido comprobar, excepto en las dos últimas obras mencionadas, el narratario individualizado se identifica con un destinatario - preferentemente un niño- que o bien desempeña las funciones propias de recepción de la narrativa tradicional, actuando como marco en el que se inscriben las demás narraciones, o bien ayuda a interpretar la narración en el caso en que ésta se adentre en el camino de la experimentalidad. De todos modos, el narratario que acabamos de exponer como individualizado sólo obedece a esta individualización por identificarse con un personaje. En ningún caso se puede hablar de narratarios desarrollados como personajes. Caso extremo de la individualización del narratario puede considerarse el de los narradores que se identifican con los narratarios tal como ocurre en ; Que me parta un rayo!, de Barrena, obra en la que el abuelo y el nieto desarrollan monólogos alternos:

Dudo si estoy en el limbo, en el purgatorio, en el cielo o en el infierno, ni si terminaré de saberlo algún día. Me da lo mismo; no se está nada mal como estoy. Mi hijo, mi nieto y ella se lo merecen un poco; sí, se merecen mi 
muerte, que la lleven a cuestas. De eso me di cuenta en el momento de caer al río, o antes quizá. Me pregunto si podía haberlo evitado. [...] ¡Je, je, je, me gusta esto de estar muerto!

El abuelo está dormido ahora, pero se ha puesto muy contento con nuestra visita. Magda y yo hemos venido a verle a otro hospital de Zaragoza, después de que me han dado el alta a mí en el mío. Mamá y papá se fueron esta mañana (Barrena, ;Que me parta un rayo!: 130- 133).

Más común que el narratario individualizado es el no individualiza$d o$, el que se presenta en el discurso a través de los elementos apelativos en la narración. Martínez Bonati (1972) aludía a esta posibilidad mencionando que lo apelado intrínseco se convierte en oyente implícito. De entre las posibles marcas discursivas la más evidente es la presencia de pronombres de segunda persona (cf. Prince, 1982: 18), además de otros factores que desarrollaremos más adelante.

La presencia de un narratario en el texto a través de su alusión en segunda persona es el procedimiento más común en el discurso que nos ocupa. Desde las obras destinadas a los prelectores hasta las narraciones dirigidas a los mayores, dentro del corpus seleccionado, la aparición de esta marca textual es generalizada.

En los libros dirigidos a los prelectores, que se desarrollan en un nivel totalmente interactivo, el narratario debe colaborar en el transcurso de la obra. La segunda persona, pues, es ineludible en la petición de la colaboración del narratario:

En el manzano hay muchos pájaros, iy alguien se va a asomar! Pero... ¿dónde está el osito de Kiper? ¡Si lees este libro seguro que lo descubrirás! El ratoncito tiene muchos amigos. Y estos, muchos más. ¿ No habéis visto al osito de Kiper? No paramos de buscar (Inkpen, ¿Dónde está el osito de Kiper?: 1-3). ${ }^{31}$

¿Cómo llamas a un gorila con un plátano en cada oreja? Como quieras porque no te va a oír.

¿Cómo sabes si hay un elefante bajo tu cama? Porque toca el techo con su trompa (Faulkner y Spender, Bromas de animales).

31 Recordamos que los libros dirigidos a los prelectores suelen basarse en la ilustración y en la manipulación de solapas. Por esta razón, en el texto aparecen mostraciones que no se comprenden si no es en relación con la imagen a la que acompañan. A este respecto se puede consultar todo lo relativo a la presencia de sistemas no verbales desarrollado en el capítulo 2 . 
En este tipo de libros el narrador solicita la participación del narratario presente en el discurso para llevar a cabo las propuestas que se le realizan. Del contenido del texto y de las presuposiciones realizadas por el narrador se infiere que el narratario es un niño cercano al mundo de los personajes que allí se muestran. ${ }^{32}$

La presencia de la segunda persona en apelación al narratario es también muy común en libros de carácter interactivo no tan marcado. En algunos casos, el narratario es clara reminiscencia de la oralidad de la que nace la narrativa infantil y que funciona como hipotexto en algunas de las obras que presentamos:

Ya conocéis a Nana Bunilda; es la que se lleva las pesadillas que no os dejan dormir en paz, y luego las transforma en chocolate. Pero no sabéis cómo consiguió su maravillosa máquina-especial-come-pesadillas, ¿verdad?

Fue toda una aventura. ¿Queréis que os la cuente? Pues... (Company y Asensio, La escoba de la bruja: 4).

¿Conocéis el cuento de Ricitos de Oro y los tres Ositos? ¿Sí? Pues, acercaos, acercaos, porque os voy a contar la historia de Pelotieso, el hermano metemiedos de Ricitos de Oro, la niña de ese cuento (Monreal y Lalana, Pelotieso y Ricitos de Oro: 8).

Sin embargo, no toda presencia del narratario en la narrativa dirigida a estas edades puede interpretarse en clave de reminiscencia de la literatura oral, aunque resuenen lejanos ecos. Así, en la mayor parte de las obras seleccionadas el narratario pertenece al ámbito de la literatura escrita a juzgar por las alusiones a otros códigos:

Y para que todos los demás niños puedan llamar al Tragasueños si lo necesitan, el rey mandó escribir e imprimir toda la historia en forma de libro, con los versos y todo. Y aquí lo tenéis (Ende, El tragasueños: 28).

¿Has pensado cuántas cosas son de veras apestosas? En los botes y en las bolsas hay basuras asquerosas. Olor a col y a pescado y olor a queso pasado para un fétido estofado (Cole, El libro apestoso: 1- 6).

¿Vais a creer lo que sucedió? La voz repitió exactamente las palabras secretas, sin olvidar ninguna. Y la bruja Mon, por arte de magia, se convirtió en un pez (Mateos, La bruja Mon: 62).

32 Cf. Piaget, 1971; Vigotski, 1982. 
Estoy contenta porque mamá me acompaña. ¿Os gustaría que vuestra madre tuviera un vehículo como éste? (Capdevila, Las nuevas historias de la bruja aburrida. Cuando era pequeña: 27).

Es también habitual la presencia de pronombres y verbos que delatan la estructura apelativa del discurso en su proyección del narratario en las obras dirigidas a niños a partir de los ocho años.

Todos los forasteros que acudían al reino enmudecían de sorpresa porque... . Podéis imaginaros a una reina que tenga cara de reina, vestidos de reina, castillo de reina, un puñado de súbditos y sólo siete pelos en su reluciente cabeza? Pues así, calva como la luna llena, era la soberana de un pequeño reino situado entre Valle Chico y Valle Grande (Company, La reina calva: 7).

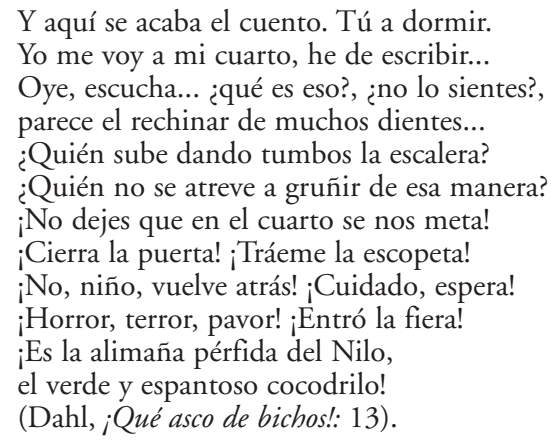

Los batautos son unos seres verdes, con orejas al principio de la cabeza y pies al final del cuerpo. Viven, viven... Bueno, seguro, no sé dónde viven. Quizás en mitad de una de esas selvas americanas que todavía no han sido exploradas, o quizás en algún desierto de África. También es posible que haya batautos en el planeta Marte, o en el de Júpiter, o quizás debajo de vuestra cama. (Mirad por si acaso.) Pero lo mejor y más seguro que podéis hacer si queréis conocer a los batautos es leer este libro. Está lleno de batautos. ¡Os lo digo yo! (Armijo, Los batautos: 6-7).

Interpretar esta presencia en la narrativa infantil únicamente en clave de oralidad no nos parece lo más acertado. Sin duda, la presencia de este tipo de recurso verbal llama la atención del lector y reclama su presencia y colaboración. Sin embargo, no podemos olvidar que la narrativa de los últimos años del siglo XX y principios del siglo XXI se dirige hacia un receptor activo que colabora en la construcción del discurso. Este narratario, por tanto, debe interpretarse asimismo en el contexto de esta directa complicidad que implica su presencia. 
Desde la perspectiva de la oralidad, sería previsible que, conforme se fuera avanzando en edad de recepción, las marcas textuales de segunda persona desaparecieran. Sin embargo, no es así. El narrador sigue optando por una relación directa con el narratario que asegura una recepción colaboradora:

Yo mismo tuve dos encuentros distintos con brujas antes de cumplir los ocho años. Del primero escapé sin daño, pero en la segunda ocasión no tuve tanta suerte. Me sucedieron cosas que seguramente te harán gritar cuando las leas. No puedo remediarlo. Hay que contar la verdad. El hecho de que aún esté aquí y pueda contártelo (por muy raro que sea mi aspecto) se debe a mi maravillosa abuela (Dahl, Las brujas: 16).

Este es Charlie. ¿Cómo estás? Y tú ¿̨cómo estás?

Charlie se alegra mucho de conoceros. [...]

Esto era para él mucho, mucho peor que ver las tabletas de chocolate en los escaparates de las tiendas o contemplar cómo los demás niños masticaban cremosas chocolatinas ante sus propios ojos. Era la cosa más torturante que podáis imaginaros, y era ésta:

¡En la propia ciudad, a la vista de la casa en la que vivía Charlie, había una ENORME FÁBRICA DE CHOCOLATE!

¿Os lo imagináis? (Dahl, Charlie y la fábrica de chocolate: 14 y 18).

En Carabanchel, que es mi barrio, por si no te lo había dicho, todo el mundo me conoce por Manolito Gafotas. Todo el mundo me conoce, claro. Los que no me conocen no saben ni que llevo gafas desde que tenía cinco años. Ahora, que ellos se lo pierden (Lindo, Manolito Gafotas: 7).

La historia que os voy a contar se desarrolla allí en Nagasaki, en aquella fecha (Alonso, El grito de la grulla: 8).

Esta recepción colaboradora puede llegar a extremos insospechados como ocurre en la colección Elige tu propia aventura, colección en la que el protagonista es el propio narratario, o en Aventuras de "la mano negra», obra en la que el narratario debe resolver los enigmas que se plantean en cada página:

Este verano, tus padres y tú os vais de viaje a Inglaterra. En Londres pasas unos días en casa de Rodney, el chico inglés con el que mantienes correspondencia.

Rodney y su familia viven en un sitio muy especial: un apartamento construido dentro del recinto de la Torre de Londres. El padre de Rodney es un yeoman warder, o sea, un guardián de la Torre. Él te explica que la Torre no es sólo una torre, sino un conjunto de 22. En ellas puedes encontrar todo tipo de cosas: torreones, mazmorras, fosos, etc., sin contar las Joyas de la Corona, los cuervos y los fantasmas (Saunders, La torre de Londres: 1). 


\begin{abstract}
Las aventuras de «la mano negra» habían comenzado un año antes en el aeropuerto. En este libro verás cómo se hicieron detectives aquellos chicos.

Busca la solución en cada dibujo y anótala en un papel siempre que hayas acertado. Encontrarás la respuesta en el texto de la página siguiente. Lee texto y dibujos con atención y cuando termines el libro, suma todos los aciertos. En la página 134 tienes la clave para poder evaluar si eres un buen detective o... si necesitas afinar tus dotes de observación (Press, Aventuras de «la mano negra»: 13).
\end{abstract}

El narratario no individualizado no se manifiesta en el discurso únicamente a través de las formas de segunda persona, sino que, como hemos expuesto anteriormente, también se infiere a través de otras marcas como pueden ser el lenguaje utilizado, las pseudopreguntas que el narrador se formula a sí mismo y, sobre todo, la estructura informativa del mensaje.

En lo que se refiere al lenguaje utilizado, el discurso narrativo literario infantil de los últimos años suele tender a utilizar, siempre en boca del narrador, un lenguaje muy cercano al niño, dependiendo, claro está, de la edad en la que se sitúe la recepción más apropiada. El lenguaje infantil y familiar se manifiesta no sólo en los giros sino también en las comparaciones que se establecen. El lenguaje nos hace inferir, en la línea de la complicidad antes mencionada, la presencia de un narratario que se identifica con el narrador en su manera de percibir y expresar la realidad... o la ficción (cf. Vigotski, 1982).

Cada vez que César Pompeyo se portaba mal, su mamá le daba un par de azotes en el culete regordete. Y cada vez que César Pompeyo desobedecía a su mamá, su mamá le daba un par de azotes en el culete regordete (Cortés y Avi, Un culete independiente: 4-7).

Al otro lado del bosque vivía una bruja que era más que mala: era remala. Por las noches se dedicaba a recorrer las granjas vecinas. [...] La bruja, que no se imaginaba lo que le iba a pasar, salió al cabo de un rato dispuesta a hacer de las suyas. Cogió la escoba, montó en ella y... jziuuuuuuuuuu... PLAF! ¡Se clavó la nariz en el suelo! (Company, La escoba de la bruja: 23-25).

Oso Pequeño jugó a dar saltos de oso, Oso Pequeño jugó a deslizarse como un oso. Jugó a columpiarse como un oso y a hacer trucos de oso con ramitas para osos. Oso Pequeño jugó a oso patas-arriba. Y Oso Grande cerró los ojos para descansar un poquito (Waddell y Firth, Tú y yo, osito: 17-19).

Pues acercaos, acercaos porque os voy a contar la historia del hermano metemiedos de Ricitos de Oro, la niña de este cuento (Monreal y Lalana, Pelotieso y Ricitos de Oro: 8). 
Y, sí, sí, un día que estaba en la clase de matemáticas quiso probar el invento y cuando el maestro le preguntó: «Dime, Filomena, ¿cuántas son diez más doce?», Filomena, de forma muy extraña y sin pensarlo dos veces le soltó:

—Culo y cola (Obiols, ;Ay, Filomena, Filomena!: 4).

Como se puede comprobar, en este tipo de discurso es muy común la presencia de términos escatológicos, estructuras recurrentes, giros familiares, coloquialismos y diminutivos afectivos, en un esfuerzo claro de adaptación al receptor último.

Conforme va avanzando la edad de este último receptor, desaparecen los términos puramente infantiles para dejar paso a un lenguaje más coloquial:

En el edificio de correos del pueblo de Bela Kabela, que era muy pocho, así como medio verde medio amarillo. Bueno, pues, en esa casa que era como un limón podrido, nada disgustaba tanto a sus habitantes como la llegada de una carta gorda (Atxaga, Nikolasa: aventuras y locuras: 7).

Era a trozos color chocolate y a trozos color chorizo. O, dicho más seriamente, entre marrón y colorado. Tenía la cabeza grande, las patas cortas y el rabo indeciso, porque apenas iniciaba una gallarda curva hacia arriba, volvía a caer como si le hubieran hecho un nudo en medio (Vázquez-Vigo, Caramelos de menta: 8).

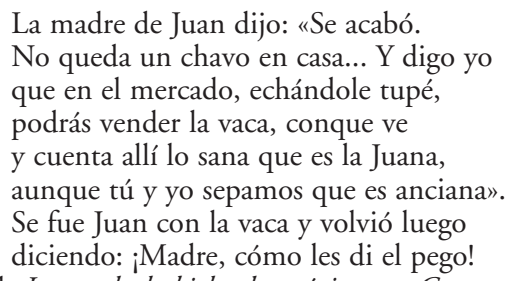

(Dahl, Juan y la habichuela mágica, en Cuentos en verso para niños per-

Lo que le pasó al señor Turell no suele pasar todos los días. Era un hombre meticuloso y ordenado como pocos. Casi nunca rompía su rutina y..., patapaf, un buen día se perdió o le robaron su sombra, vaya usted a saber. Aquella tarde hacía un sol de campeonato. Todo el mundo sudaba la gota gorda (Cela, El ladrón de sombras: 7).

En el momento en que nos vamos acercando a la etapa de transición hacia la novela juvenil —aproximadamente a partir de diez años—, se siguen utilizando expresiones coloquiales y términos escatológicos como en las etapas anteriores, y quizá lo más destacable sea una sintaxis muy relajada, muy cercana al lenguaje oral, en algunos casos: 
¿Cómo dejar a Bambulo en la sima del olvido? ¿Cómo dejar a Bambulio, Bambulko, Bambulias, Bambulides y demás antepasados en la oscuridad de la historia? No, de ninguna manera. Claro que no. No y no. En absoluto. La gente debe saber. Al fin y al cabo, para eso está la gente, para aprender lo que no sabe y para recordar lo que ha olvidado (Atxaga, Las bambulisticas historias de Bambulo. Primeros pasos: 8).

Algunos padres van aún más lejos. Su adoración llega a cegarlos y están convencidos de que su vástago tiene cualidades de genio.

Bueno, no hay nada malo en ello. La gente es así. Sólo cuando los padres empiezan a hablarnos de las maravillas de su descendencia es cuando gritamos: «iTráiganme una palangana! ¡Voy a vomitar!» (Dahl, Matilda: 11).

Mi abuelo no pudo salir corriendo detrás de él porque como está de la próstata pues es como el que tiene un tío en Alcalá, que ni tiene tío, ni tiene ná. Las gafas estaban tan altas que tuvimos que bajarlas a base de tirar piedras. Así que nos volvimos a casa. Mi madre primero me abrazó cuando vio cómo me había puesto el ojo y luego me dio una colleja cuando vio cómo me habían puesto las gafas (Lindo, Manolito Gafotas: 41).

Cuanto más se adentra el narrador en el nivel de la experimentación literaria, como ocurre, por poner un ejemplo, en Los apuros de un dibujante de historietas de Farias, la sintaxis es más sencilla, quizás con el objetivo de no complicar demasiado el discurso. Así, desde el punto de vista tipográfico, esta obra que juega con dos niveles de ficción distingue uno de ellos a través de la cursiva.

En las ocasiones en las que se remeda la escritura, la sintaxis se simplifica, más de lo que sería previsible, en aras de los principios de la verosimilitud, tal como ocurre en Me importa un comino el rey Pepino, de Nöstlinger:

\author{
Describo quiénes somos. \\ Lo que apareció de repente en la cocina. \\ El redactor jefe no quiere saber nada. \\ Las cámaras de fotos tampoco quieren, a pesar de que hay cinco. \\ Empezó mucho antes. Pero no nos dimos cuenta hasta el pasado domin- \\ go de Pascua, a la hora del desayuno. Primero hizo un ruido. Yo creí que se \\ había caído algo en la cocina. Mamá fue a ver y, cuando volvió, temblaba y \\ nosotros... (Nöstlinger, Me importa un comino el rey Pepino: 11).
}

Insistimos en la sintaxis de este tipo de obras, no porque en los demás niveles no se simplifique sino porque lo previsible en estas narraciones sería la complicación. Es evidente que la sencillez de la sintaxis —oraciones simples, estructuras de sujeto, verbo, objetos directo, indirecto y cir- 
cunstanciales, yuxtaposición- es una de las características de estilo común al discurso que estamos estudiando.

Desde el punto de vista del lenguaje, pues, podemos concluir en que este se intenta adaptar a la competencia teórica del narratario que, en muchos de los casos, coincide con el lector textual en lo que a este ámbito se refiere.

La estuctura apelativa del discurso y su orientación hacia el narratario se manifiesta también en las pseudopreguntas que el narrador se formula a sí mismo. El discurso narrativo infantil literario, sin distinción de edades de recepción, presenta abundantes muestras de este tipo de recurso que solicita la participación del narratario en la realización de inferencias y, a su vez, contribuye a modelarlo:

¡Por favor, por favor!, tállame un bebé. Uno pequeñito. ¡Por favor, por favor! ¿Qué debía hacer el pobre maestro? Nunca hasta entonces había hecho un bebé para el bebé de una muñeca (Inkiow, Matrioska: 44).

Salustiano, aunque no quiera, debe entrar en la bañera. Flor prepara en la cocina pasteles con miel y harina. Papá seca con cuidado a Salustiano empapado. Y, mientras, ¿qué hace Julieta? Esperar y estarse quieta... (McKee, iJulieta, estáte quieta!: 13-16).

Quedó colgado cabeza abajo, mientras agitaba los brazos como si intentara alzar el vuelo. De momento había conseguido salvar el pellejo. Pero... ¿cuánto tiempo resistirían las ramas? (Alcántara, ;Huy, qué miedo!: 34).

Ramona se quedó tan atónita que ni siquiera intentó oír la respuesta de la señora Larson. ¡Graciosita! ¡Latazo! ¿Qué creía la señora Ballenay, que se había cascado un huevo crudo en la cabeza para hacerse la graciosita? Y que su profesora decía que era un latazo cuando no lo era. ¿O sí lo era? Ramona no había pretendido romperse el huevo encima de la cabeza. La culpa la tenía su madre. ¿Se habría convertido en un latazo por lo del huevo? (Cleary, Ramona empieza el curso: 51).

Un buen vino, unos choricitos, una tortilla de cebolla y un helado de vainilla y jadelante con la reflexión! ¿Quién podía estar interesado en robar una sombra? ¿Habían desaparecido otras? ¿Para qué podía servir una sombra? (Cela, El ladrón de sombras: 58).

Por fin entramos y... ¿Qué era aquello? Algo había pasado. El suelo estaba lleno de frascos rotos, papeles estrujados, estanterías volcadas. Había fuego en la mesa de la izquierda. Las llamas crecían por momentos... Porfirio salió por la puerta como una exhalación, sin decir nada, mientras yo seguía allí, paralizado, incapaz de mover un solo dedo (Mendo, El vendedor de agujeros: 50). 
Pero ¿cómo es que eran dos? ¡Rüdiger siempre había venido solo! ¿Sería, quizá, una trampa? ¿Habrían quizá llegado a saber dónde vivía? Pero ¿`no le habría prevenido entonces Rüdiger? No, reflexionó Anton, era mucho más probable que fuese el propio Rüdiger..., pero ¿̇a quién podía haber traído consigo? (Sommer-Bodenburg, El pequeño vampiro: 94).

Pero, en realidad, ella no estaba de acuerdo. En primer lugar, no creía que un chico de siete años tuviera tanta necesidad de un padre. $Y$ en segundo lugar, de necesitar un padre, ¿por qué uno tan aburrido, tan tontaina como Egon? (Nöstlinger, Konrad o el niño que salió de una lata de conservas: 47$)$.

Así pues, las marcas apelativas en el discurso que nos ocupa son muy abundantes. Los ejemplos son numerosos en todas las obras seleccionadas, lo cual nos lleva a destacar que el narrador de este tipo de discurso busca constantemente la participación directa del narratario. Preguntas como las que hemos expuesto tienden a llamar la atención del narratario para que construya sus propias hipótesis sobre el desarrollo de la narración, hipótesis que serán confirmadas o revisadas por el propio texto.

\subsubsection{El grado de conocimiento del narratario. La perspectiva}

Hasta ahora hemos expuesto cómo los diferentes narradores van creando la imagen de su narratario, unas veces más individualizado, otras veces en el camino de la coincidencia con el lector textual, a través de un proceso de suposiciones que solicitan del destinatario su colaboración. Una vez estudiada la identidad del narratario, necesitamos saber cuál es el grado de conocimiento que el narrador presupone en el narratario.

Nos interesa sobremanera a este respecto retomar las cuestiones de grado de información del narrador y la focalización por parte de este. En los casos en que nos acercamos a la focalización cero, el narrador, generalmente omnisciente, presume un narratario que desconoce parte de la historia, aunque conoce las bases de las que parte:

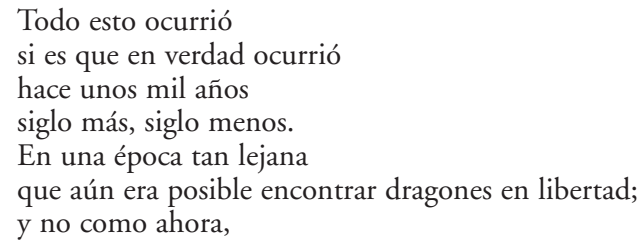




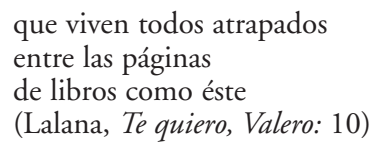

Ya conocéis a Nana Bunilda; es la que se lleva las pesadillas que no os dejan dormir en paz y luego las transforma en chocolate. Pero no sabéis cómo consiguió su maravillosa máquina-especial-come-pesadillas, ¿̇verdad? ¿Queréis que os la cuente? (Company y Asensio, La escoba de la bruja: 4).

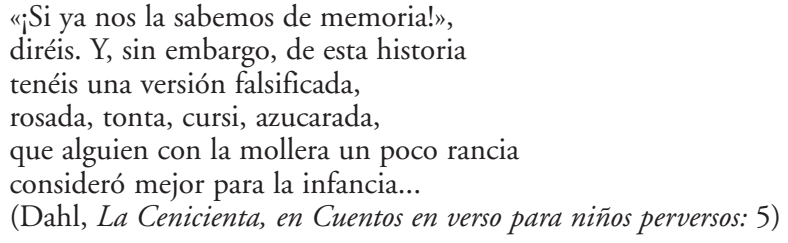

Filomena era una niña que tenía mucha imaginación, tanta imaginación que cuando explicaba alguna cosa, la gente mayor no la entendía porque hablaba de manera diferente y todos se hacían un verdadero lío al oírla. Cuando Filomena se ponía a parlotear, siempre acababan diciendo lo mismo:

—Ay, Filomena, Filomena!

— Qué disparates estás diciendo!

- Niña, cuando te pones a hablar, te quedas sola.

Pero ella no les hacía ni caso puesto que su lenguaje era secreto y sólo se lo había enseñado a los otros niños, y así toda la pandilla acabó hablando como Filomena. Y entre ellos, jya lo creo que se entendían! (Obiols, ;Ay, Filomena, Filomena!: 3).

Distinto es el caso de los narradores que optan por la focalización interna y presuponen la existencia de un narratario que conoce y comprende la acción al mismo nivel que el narrador, un narratario que coincide en su percepción del mundo y acepta la fiabilidad del mismo. De este modo, se fomenta una solidaridad, casi siempre irónica, entre el autor textual y el lector textual. El narrador y el narratario no poseen los mismos conocimientos que el autor y el lector textuales, ignoran, como mínimo, todos los elementos metatextuales de la obra tales como el título, las referencias editoriales, los prólogos, etc. Ejemplos como los de Munia y el cocolilo naranja, o Munia y la luna, de Balzola; Ha sido el pequeño monstruo, de Cooper; Fantasmas de día, de Baquedano; El pequeño Nicolás, de Goscinny; Manolito Gafotas, de Lindo; o Ben quiere a Anna, de Härtling, por citar algunos, pueden servir para ilustrar esta posibilidad. 
Mamá nos llamó para ver si podíamos ser todos amigos. Pero el Pequeño Monstruo no quería.

— ¿No podríamos devolver al bebé? —pregunté.

Mamá contestó que no.

- Nos necesita para que lo cuidemos. ¿Qué haría él solito?

"¿Qué haría él solito?», pensé.

Después le ayudé a secarse los pies. Y le conté cuentos hasta que se durmió. Al pequeño Monstruo no le gustó nada. Me vino a buscar y me sacó de allí (Cooper, Ha sido el pequeño monstruo: 22-25).

Yo al principio le tenía mucho miedo y hasta lloraba, pero me convencí de que Aspirador es bueno y lo que pasa es que el pobre tiene mucha hambre. $\mathrm{Y}$ es bien considerado, pues lo único que quiere es comerse las migas de pan y de galleta que yo he ido tirando por el césped del castillo, que ellas, las dos, la bruja y el hada, llaman, moqueta (Martín, Yo viví con una bruja: 16).

Tenemos mucha suerte en el metro porque, aunque vaya muy lleno, mi abuelo y yo juntos damos mucha pena y siempre nos dejan el sitio. Mi abuelo da pena porque es viejo y está de la próstata. La próstata no se le ve pero sí se le ve que es viejo. A lo mejor yo doy pena porque llevo gafas, no te lo puedo asegurar.

Cuando la gente nos deja el sitio nos vemos en la obligación de poner cara de pobres desgraciados, porque si, por ejemplo, te dejan el sitio y vas y te sientas y te partes de risa inmediatamente la gente se mosquea. Así que mi abuelo y yo siempre entramos en el metro como hechos polvo y siempre nos da resultado. Pruébalo, pero tampoco se lo vayas contando a todo el mundo, a ver si al final se corre la voz y se nos acaba el chollo (Lindo, Manolito Gafotas: $14-15)$

Nos dispusimos sobre el campo. Como no éramos más que siete a cada lado, aparte los porteros, no era muy fácil. En cada equipo se empezó a discutir. Había montones que querían ser delantero centro. Joaquín quería ser extremo derecho, pero era porque la moneda había caído en aquella esquina y quería seguir buscándola mientras jugaba.

En el equipo de Godofredo la cosa se arregló pronto, porque Eudes dio montones de puñetazos y los jugadores se pusieron en sus sitios sin protestar y frotándose la nariz. ¡Pega muy duro este Eudes!

En mi equipo no conseguíamos ponernos de acuerdo hasta que Eudes dijo que vendría a darnos puñetazos en la nariz a nosostros también; entonces nos colocamos (Goscinny, El pequeño Nicolás: 35 ).

La extensión de las citas nos permite comprobar cómo el narrador, a través de su actitud interlocutiva, se define a sí mismo y define a un narratario con el que establece una relación de complicidad comprensiva. Este hecho facilita, como hemos señalado más arriba, que el lector textual se solidarice irónicamente con el autor textual y se establezca asimismo un desdoblamiento del receptor en dos destinatarios: el narratario y el lector 
textual. Aunque no esté individualizado, el narratario es una instancia construida por el narrador en cuanto que comparte su percepción de la historia, y el lector textual, mucho más informado que el narratario, es el receptor infantil, por una parte, y el adulto, por otra. Sólo de esta forma, desde el propio discurso, podemos justificar la presencia del doble destinatario en la narrativa infantil. En este sentido, el discurso narrativo literario infantil retóricamente opta por presentar al lector dos frentes en su interpretación: el del narratario y el del lector textual.

Así, en lo que respecta a los ejemplos aducidos, descubrimos, por ejemplo en Manolito Gafotas o en El pequeño Nicolás, cómo el narratario comparte la visión de los protagonistas, sin ir más alla, y el lector textual, sin embargo, accede a la ironía que se desprende del texto al descubrir las intenciones del autor textual, responsable de la disposición del texto, de su organización y de varios de los elementos metatextuales que recogen las múltiples fuerzas ilocucionarias que se despliegan en el mismo discurso. La ironía que se desprende de estos textos parte de la diferenciación entre narratario y lector textual. Diferenciación que se muestra evidente en los casos en que el narrador realiza una serie de presuposiciones sobre el narratario que no se corresponden con los conocimientos de este, tal como acontece en Las bambulisticas historias de Bambulo. Primeros pasos, de Atxaga:

Mucho se ha escrito sobre la personalidad del verdadero descubridor de América. Unos dicen que fue un soldado vikingo; otros, que un marinero vasco de Villarreal de Urretxua; otros más, la mayoría, que el genovés Cristóbal Colón. Pues bien: no fue ninguno de los tres. Fue Bambulegui, uno de los perros con más vista del continente (Atxaga, Las bambulisticas historias de Bambulo. Primeros pasos: 62).

En lo que concierne a los discursos en los que el narrador opta por una focalización externa, característica muy frecuente en la narrativa dirigida a las primeras edades, el narrador tiende a confundirse con el autor textual, de la misma forma que el narratario se puede confundir con el lector textual. Aun así, creemos que el propio discurso retóricamente exige el desdoblamiento del destinatario. Ejemplos, entre otros, como el de Ahora no, Fernando, de McKee, o las historias de Sapo y Sepo, de Lobel, podrían ilustrar la afirmación que acabamos de realizar. En estos casos, el narratario se va construyendo a través del lenguaje utilizado por los personajes en los omnipresentes diálogos, a través de la organización de la información, 
mediante la colaboración de las imágenes, etc. Además casi todas las obras en las que predomina la focalización externa, por otra parte, son de extensión muy breve, lo cual, en principio, las acerca a un narratario que comienza a leer. Ahora bien, este narratario que se identifica con los protagonistas asiste a la sucesión lineal de diálogos y de imágenes sencillas y sugerentes a la vez. El problema que se nos plantea es que, en los discursos con estas características, la ironía es una clave de interpretación. Quiere esto decir que se establece, una vez más, por encima del narratario, una complicidad entre autor textual y lector textual. Así por ejemplo, en el cuento titulado La sorpresa perteneciente a la obra Sapo y Sepo, un año entero, de Lobel, Sapo decide dar una sorpresa a Sepo y barrer todas las hojas que el viento del otoño ha esparcido por su césped y Sepo, a su vez, decide realizar la misma labor en la casa de Sapo, pero...

\footnotetext{
Se levantó viento. Sopló removiéndolo todo. El montón de hojas que Sapo había barrido para Sepo voló por todas partes. El montón de hojas que Sepo había barrido para Sapo voló por todas partes.

Cuando Sapo llegó a casa dijo:

- Mañana limpiaré las hojas que cubren todo mi césped. ¡Qué sorpresa se habrá llevado Sepo!

Cuando Sepo llegó a casa dijo:

- Mañana me pondré a trabajar y barreré todas mis hojas. ¡Qué sorpresa se habrá llevado Sapo!

Esa noche, a la hora de apagar la luz para dormirse, Sapo y Sepo, los dos, se sentían tan felices... (Lobel, La sorpresa, en Sapo y Sepo, un año entero: 52-55).
}

Como se podrá comprobar, el narrador no mediatiza con sus comentarios la acción sino que expone simplemente lo que los personajes hacen y dicen. La ingenuidad de los personajes y su optimismo corresponden a la línea de actuación habitual de unos caracteres ya muy marcados. La sencillez de la línea argumental desarrollada mediante diálogos paralelos construye un narratario infantil. Únicamente la entonación suspensiva constituye una marca textual que adentra al destinatario en el ámbito de la comicidad irónica. Autor y lector textuales se ponen en contacto en otro sentido del discurso que no siempre descubre el narratario infantil. El narratario, pues, en estas obras, asiste a la sucesión de acciones, y el narrador presume en él el mismo grado de conocimiento que el suyo; de este modo construye el destinatario su propio significado.

Lo mismo ocurre en Ahora no, Fernando de McKee, narración en la que la ilustración desempeña un papel más importante que en el ejemplo 
anterior. Una vez más el narrador propone una sucesión de diálogos como explicación de cada una de las imágenes que aparecen en la obra a modo de viñetas:

\footnotetext{
«Hola, papá», dijo Fernando. «Ahora no, Fernando», dijo su padre.

«Hay un monstruo en el jardín y me va a comer», dijo Fernando. «Ahora no, Fernando», dijo su madre.

El monstruo se comió a Fernando enterito. No dejó ni una pizca. Luego el monstruo entró en la casa. "GRRR...», hizo el monstruo detrás de la madre de Fernando. "Ahora no, Fernando», dijo la madre de Fernando.

El monstruo mordió la pierna del padre de Fernando. "Ahora no, Fernando", dijo el padre de Fernando.

"Tu cena está lista», dijo la madre de Fernando. Y puso la cena delante de la televisión. El monstruo se comió la cena de Fernando. Luego miró la televisión. Después leyó alguna de las historietas de Fernando. Y rompió alguno de sus juguetes.

«Vete a la cama. Te he llevado un vaso de leche», gritó la madre de Fernando. El monstruo subió las escaleras. "Pero si soy un monstruo...», dijo el monstruo.

«Ahora no, Fernando», le contestó la madre de Fernando.
}

Este álbum desarrolla una línea argumental muy sencilla, basada en las recurrencias y en la ruptura del horizonte de expectativas del narratario, narratario al que se le exige una construcción del significado a partir de las sugerencias que conjuntamente elaboran texto e imagen. La mediación del adulto, pues, se convierte en indispensable. Por otra parte, el adulto se identifica con los padres reconociendo en ellos muchas de las actitudes habituales provenientes de la falta de comunicación con los hijos. El autor textual no sólo se comunica con el narratario sino que establece una complicidad con el lector textual, que engloba tanto al niño como al adulto que colabora en la interpretación.

En definitiva, el narratario comparte o debe compartir la misma perspectiva que el narrador, quien a su vez va construyendo la imagen del narratario. Este, en principio, nunca posee la misma información que el autor y el lector textuales.

Así pues, retóricamente conviene diferenciar al narratario del lector textual, tanto en su identidad como en lo que concierne al grado de conocimiento de la acción, aun cuando el narratario no se encuentre demasiado individualizado, como ocurre en algunos casos. Aunque puedan parecerlo, narratario y lector textual no son siempre identificables y, como 
hemos expuesto, en esta falta de identificación radica una de las principales e innovadoras características del discurso narrativo infantil de finales del siglo XX.

\subsection{El lector textual ${ }^{33}$}

El lector textual desempeña un papel estructural respecto del autor que es comparable en algunos aspectos al papel del autor textual respecto del lector. El lector textual o implícito es el receptor previsto por el autor en la elaboración de su mensaje. Ya que todo discurso requiere la existencia de un lector textual o implícito, no es de sorprender, como explica García Landa (1998: 416), que las raíces de este concepto se hayan encontrado en Aristóteles (cf. Ricoeur, 1983: 50), aunque no explícitamente formulado.

En el siglo XX múltiples han sido los autores que han estudiado este concepto $^{34}$ básicamente definido como el catalizador de todos los mecanismos utilizados para instalar al lector real en el texto. En la definición del lector textual desempeña un papel muy importante el concepto de enciclopedia:

En el caso de las actividades discursivas complejas como la literatura, es más adecuado hablar de sistemas de códigos. En efecto, cualquier código significativo es capaz de contribuir al significado de una obra literaria, ya sea a nivel de mundo narrado [sic] y acción, de relato o de discurso. La "competencia literaria» está pues constituida por el dominio de los códigos significativos de una cultura dada en función de esta capacidad de relevancia para la literatura. Naturalmente cada interlocutor tiene su propia competencia literaria, con lo cual la significación de la obra para autor y lector puede variar en mayor o menor grado. No se trata de una gramática inflexible que permitiría dar un sentido único a cada texto. Es preferible el término de «enciclopedia» o «enciclopedias». Una enciclopedia se caracterizaría, frente a una gramática, por

33 Utilizaremos habitualmente en nuestra exposición el término lector textual como sinónimo de lector modelo (Eco, 1987) con la única finalidad de asimilarse a lo que hemos denominado autor textual y destacar, de este modo, la virtualidad de las dos instancias enunciativas.

34 Cf. Kayser (1985), Ayala (1984), Tacca (1973), Eco (1987), Lanser (1981), Lozano, Peña-Marín y Abril (1980) y Villanueva (1984), entre otros. Por el contrario, algunos autores, entre los que destaca Adams (1985), niegan la pertenencia de este concepto al contexto pragmático de la comunicación literaria. 
incluir todos los códigos y datos a disposición del hablante, organizados según los esquemas semánticos y situacionales que les permiten activarlos para su actuación en el mundo (García Landa, 1998: 420-421).

Es la constante referencia al lector, a sus conocimientos enciclopédicos de todo tipo lo que permite la comprensión del texto. Eco (1987: 166167) señala que los "paseos inferenciales" guiados por el propio texto, a través de la enciclopedia del destinatario, son los que, en última instancia, permiten la comprensión del discurso. De este modo, el lector recibe cada obra en función de su enciclopedia literaria personal de acuerdo con una serie de convenciones cultural y socialmente elaboradas. Por otra parte, el autor presupone la competencia literaria del lector modelo y, a su vez, contribuye a modificarla e instituirla. En algunos casos, la competencia «instituida" por la obra es de validez provisional, tal como ocurre en las obras de fantasía. La competencia literaria implica una competencia lingüística en la que se integran los códigos del diccionario básico y las reglas de correferencias postuladas por Eco (1987); una competencia genérica - hipercodificación retórica y estilística-; una competencia intertextual; y una competencia o hipercodificación ideológica. En este sentido, el concepto de intertexto lector de Mendoza (2001 y 2004) vendría a aplicar a la formación del lector literario y al proceso de interpretación las ideas ya expuestas por Kristeva, Riffaterre, Genette y el propio Eco.

\subsubsection{El lector textual en la narrativa infantil}

Pocos estudios han versado sobre el análisis del lector textual o modelo en la narrativa infantil. El más exhaustivo es el de Lluch (1998) referido, sobre todo, a la narrativa infantil catalana. Esta estudiosa parte en su libro del concepto de lector modelo y lo aplica a la producción literaria infantil catalana mayoritariamente. Establece asimismo una diferenciación entre el lector de la narrativa oral y el lector de los textos paraliterarios con los que la narrativa infantil presenta, en su opinión, bastantes concomitancias que, a nuestro entender, son meramente formales. Se analizan en la obra los diferentes conceptos de autores, desde el instructor hasta el autor actual, y el papel que desempeñan los agentes de transformación —educativos, institucionales y editoriales-. Los paratextos, los códigos y subcódigos y los diversos tipos de competencia requerida en el lector completan este trabajo. Insiste Lluch (1998) en la influencia que sobre el discurso narrativo 
infantil ejercen los medios de comunicación y lo que se denomina «agentes de transformación», es decir, los criterios institucionales, editoriales y educativos.

Otros estudios han tratado del lector modelo de una forma más somera. Así, Colomer (1998: 144-146) como hipótesis de su estudio establece las características del nuevo lector al que se intenta adaptar la literatura infantil y juvenil del último cuarto de siglo. Este nuevo lector que define la estudiosa citada presenta las siguientes características:

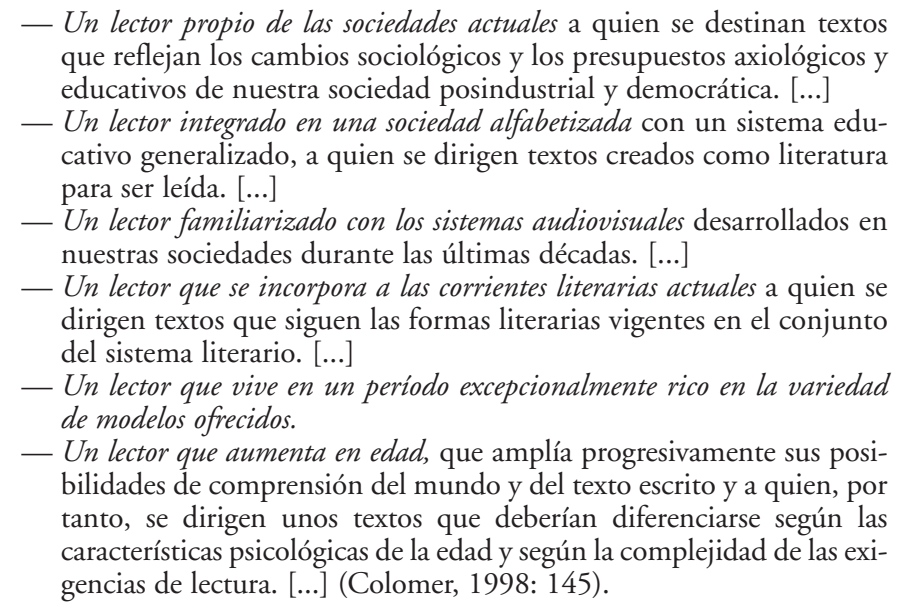

Este tipo de lector que constituye una estrategia interpretativa se ha reflejado en el transcurso de estas páginas. Estamos de acuerdo con las características que ofrece Colomer, a pesar de que entendamos que en los primeros años del siglo XXI algunos factores se hayan perfilado un poco más.

Así, la incorporación de la literatura infantil al currículum educativo ha facilitado definitivamente su consolidación en el mercado editorial, aunque, por otra parte, haya sacrificado algunos de los principios de la calidad literaria en aras de fines totalmente espurios. Nos referimos al didactismo soterrado de algunas de las publicaciones y a la desmesurada influencia de la mediación editorial, comercial, en la mayor parte de los casos. Asimismo, la entrada en el ámbito escolar ha facilitado la asimilación de nuevas tendencias literarias puesto que la mediación del adulto — maestros, grupos de lectura, etc. - asegura las nuevas posibilidades. 
En lo que respecta al lector familiarizado con los sistemas audiovisuales, es inexcusable mencionar la consolidación de este aspecto que, sin duda, constituye uno de los principales cauces de innovación, por una parte, y de reivindicación de una confianza en la competencia literaria del receptor, por otra. Obras, en este sentido, como La carta de la señora González, de Lairla y Lartitegui, y Hasta (casi) cien bichos, de Nesquens y Arguilé, corroboran la presencia de un nuevo receptor.

Por otra parte, el siglo XXI abre paso a una literatura fudamentalmente escrita, no sujeta a la recepción colectiva y que, sin embargo, considera que la «lectura en voz alta» por parte del adulto es, sin duda, uno de los mejores procedimientos para fomentar los hábitos lectores en las primeras edades. En esta línea, tal como hemos mencionado anteriormente, el siglo XXI se abre con nuevas formas de contar, nuevas formas de oralidad que implican la apertura a nuevos códigos.

Aunque el lector textual requeriría un monográfico por sí mismo, vamos a desarrollar someramente los aspectos textuales a nuestro entender más relevantes en lo que respecta a esta instancia enunciativa.

\subsubsection{La intertextualidad. Tejiendo textos}

La estructura informativa del mensaje, la sucesión de temas y remas, ${ }^{35}$ es uno de los elementos a través de los cuales el discurso construye su propio lector. Sobre el telón de fondo de lo conocido se propone la información nueva. Así, el narrador distribuye la información de tal modo que va formando la imagen del lector textual. El narrador da por supuestos ciertos conocimientos del narratario sobre acciones, lugares, objetos, personajes y explica aquello que el narratario, se supone, desconoce. En definitiva, estamos interpretando la cooperación textual como una actividad que se realiza entre dos estrategias discursivas y no entre dos sujetos individuales. Es decir el narrador, el narratario, el autor textual y el lector textual no son individuos sino estrategias que emanan del propio discurso, tal como percibe Eco (1987: 91).

En lo que respecta a la narrativa infantil, sería muy difícil determinar una línea general para definir qué es lo que se le solicita al lector en el

35 Estos conceptos fueron introducidos por la escuela de Praga. Equivaldrían a lo que la crítica anglosajona se denomina topic y comment (cf. Segre, 1985: 41). 
ámbito de la información. Esto supondría un análisis pormenorizado de cada una de las narraciones seleccionadas. No obstante, podemos establecer algunos rasgos generales que suponen la adquisición previa de cierta «enciclopedia» por parte del lector para poder interpretar la obra. A este respecto, es conveniente recordar las palabras de Eco (1987: 76):

Así pues, el texto está plagado de espacios en blanco, de intersticios que hay que rellenar; quien lo emitió preveía que se los rellenaría y los dejó en blanco por dos razones. Ante todo, porque un texto es un mecanismo perezoso que vive de la plusvalía de sentido que el destinatario introduce en él y sólo en caso de extrema pedantería, de extrema procupación didáctica o de extrema represión el texto se complica con redundancias y especificaciones ulteriores. En segundo lugar, porque, a medida que pasa de la función didáctica a la estética, un texto quiere dejar al lector la iniciativa interpretativa, aunque normalmente desea ser interpretado con un margen de univocidad. Un texto quiere que alguien lo ayude a funcionar.

En la línea de contemplar el texto como una máquina (Eco, 1987: 39), la narrativa infantil de los últimos años, con la finalidad de conseguir un destinatario constructor de significados y de alejarse de la función didáctica, ha utilizado como procedimiento generalizado las inferencias intertextuales. Así el narrador presume en el lector unos conocimientos literarios sin los cuales el discurso se desarticula. Nos referimos a la presencia de la hipertextualidad, clase de transtextualidad que Genette (1989b: 15) define como toda relación que une un texto B (hipertexto) con un texto anterior A (hipotexto), de tal forma que no se puede llegar a interpretar el primer texto en toda su extensión si no se conoce previamente la base de la que parte. En estos casos, el narrador presupone en el lector el conocimiento del hipotexto sin el que el hipertexto carece de sentido. La hipertextualidad, en muchos casos, ofrece ejemplos de intertextualidad cuando las alusiones textuales son literales en el hipertexto (Genette, 1989b: 11). ${ }^{36}$ En esta línea y como hemos señalado al referirnos a la educación literaria, el concepto de intertexto lector acuñado por Mendoza (2001 y 2004) viene a concretar el proceso de la recepción. Ejemplos de esta práctica encontramos en algunos de los textos seleccionados den-

36 Las relaciones transtextuales han sido estudiadas por Kristeva (1976: 273-306) y por Riffaterre (1971). En nuestra exposición utilizamos los términos acuñados por Genette (1989b) que no siempre coinciden en su definición con los utilizados por los dos estudiosos citados anteriormente. 
tro de los tres bloques diferenciados por edades. Así en El cartero simpático, la alusión a los cuentos tradicionales es constante. Sería imposible interpretar el sentido de la carta que Ricitos de Oro envía a los Tres Osos sin conocer previamente el cuento popular:

Queridos Sr. y Sra. Oso y el pequeño también:

Lo siento mucho. Estube [sic] en su casa y me comí la papiya del osito. Mamá dice que soi mala porque no me como la papiya que ella ace. Papá dice que arreglará la silla.

Un beso de Rizosdeoro (Hnos. Ahlberg, El cartero simpático).

Del mismo modo, la obra de Te quiero, Valero, de Lalana, basa su sentido en el conocimiento de la leyenda de San Jorge y toda la serie de Las tres mellizas sólo se comprende a través de las múltiples referencias a la historia en la que se introducen, tal como ocurre en las Las tres mellizas y la Cenicienta. Así como el Libro de las M'Alicias sólo se interpreta en su relación con la obra de Carroll, o los Cuentos en verso para niños perversos adquieren su último sentido en el conocimiento de la tradición cuentística:

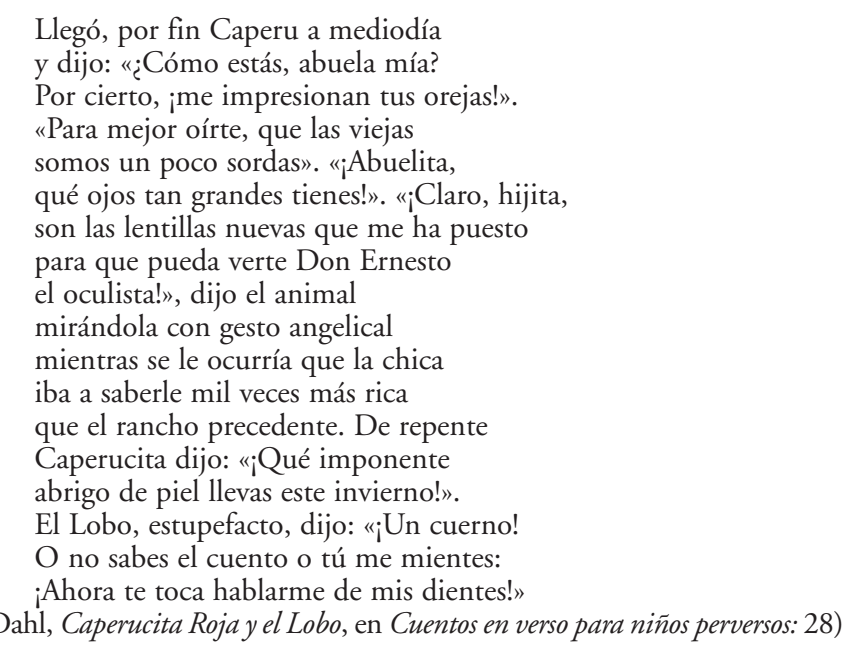

De este modo, el hipotexto se manifiesta también como base explícita e implícita en una obra como Yo viví con una bruja, de Martín:

El otro día, ipor fin!, conseguí entrar sola en el torreón de «Irás y no volverás». Allí descubrí algo sorprendente, que cuando os lo diga no vais a creer que 
sea verdad. Resulta que el pájaro Plumero, cuando el hada no lo saca a volar, no vive en una jaula de oro como todos los pájaros de los castillos, vive en una especie de pasadizo secreto que hay en el torreón (Martín, Yo viví con una bruja: 30).

No siempre las alusiones al hipotexto son tan directas y expresas como las que acabamos de exponer. En otras ocasiones, el hipotexto se desarrolla en la línea de los tópicos acuñados por la tradición que los niños conocen desde los primeros años. En este sentido, es destacable la presencia en la narrativa infantil de la desmitificación como procedimiento muy utilizado que desemboca generalmente en el humor como recurso distanciador. La desmitificación se basa en el extrañamiento del horizonte de expectativas del lector, lo cual implica, claro está, que el horizonte de expectativas del lector debe responder a las previsiones realizadas por el narrador. De este modo, el discurso ofrece brujas buenas —iHuy, qué miedo!, de Alcántara; La escoba de la bruja, de Company; ¡Papá!, de Corentin-, dragones inofensivos - Te quiero, Valero, de Lalana-, cocodrilos pacíficos y amables — Munia y el cocolilo naranja, de Balzola-, lobos incomprendidos - El lobo feroz, de Monreal y Lalana-, monstruos juguetones —Donde viven los monstruos—, madres desordenadas y niños harto responsables - Konrad o el niño que salió de la lata de conservas-, ladrones que se vuelven buenos - El secuestro de la bibliotecaria-, etc. La desmitificación implica en el lector haber interiorizado los tópicos propios de la tradición literaria popular.

Este procedimiento no se basa únicamente en el extrañamiento de los personajes sino que también se extiende a la historia. Así el niño acostumbrado a la narrativa tradicional como género que basa su atractivo en la autoconfirmación, ${ }^{37}$ en no defraudar las expectativas del oyente, tanto en lo que respecta a las funciones como en lo que concierne a los actantes y actores, se encuentra en la narrativa objeto de nuestro análisis con narraciones como la de La reina calva, de Company, o El tragasueños, de Ende, obras en las que las funciones tradicionales son desempeñadas por personajes que nada tienen que ver con ellas.

Muy vinculado a la desmitificación está el procedimiento de la parodia (cf. Genette, 1989b: 22 y ss.) que supone en el lector la interiorización de ciertos esquemas procedentes de la tradición popular y el extrañamien-

37 Cf. Lotman, 1970; Propp, 1971. 
to de los mismos a través de la presentación de personajes que, respondiendo a los tópicos, no acaban de desempeñar completamente su función. Así en La bruja Mon, de Mateos, la protagonista, a pesar de ser, como corresponde, una bruja mala, no consigue que sus hechizos surtan el efecto deseado sino justamente el contrario:

Y la voz, sin acobardarse, le devolvió la amenaza:

- Voy a convertirte en un pez tonto!

—iA mí? —dijo la bruja Mon-. ¡Y un jamón! Agitó su polvorienta varita y dijo, rápidamente las palabras secretas [...]. ¿Vais a creer lo que sucedió? La voz repitió exactamente las palabras secretas, sin olvidar ninguna. Y la bruja Mon, por arte de magia, se convirtió en un pez. El otro día la vi dentro de la pecera. ¡Y estaba roja de rabia! (Mateos, La bruja Mon: 60-63).

En El pequeño vampiro, de Sommer-Bodenburg, Rüdiger es un vampiro que se asusta de la oscuridad y en Las brujas, de Dahl, las protagonistas son terroríficas pero adquieren la presencia de una mujer normal si no fuera porque continuamente se rascan la cabeza y están torturadas por los zapatos de tacón ya que no tienen dedos en los pies.

De parodia podemos tildar asimismo la obra de Atxaga titulada Las bambulísticas historias de Bambulo. Primeros pasos. En esta narración el secretario del protagonista recoge y publica las memorias de Bambulo, remedando una estructura propia de las memorias de un personaje histórico solvente e importante, acreditando fragmentos de un supuesto diario, adjuntando prólogos y epílogos, etc. Solamente un detalle nos lleva a interpretar la obra en clave de parodia: Bambulo es un perro y la narración camina en esa línea puesto que la perspectiva es la de ese animal:

Querido lector: el recorrido vital de nuestro perro Bambulo ha sido completamente redondo. No quiero decir con ello, de ningún modo, que no haya tenido defectos o no haya dejado lugar a alguna que otra duda, sino que, simplemente, comenzó en un punto, dio una gran vuelta y regresó. Él mismo lo declaró en una entrevista: «He andado de ciudad en ciudad y de biblioteca en biblioteca, he caminado por medio mundo, y, al final, ;con qué me encuentro? Pues con el mismo hueso que enterré en mi juventud». Una verdad como un templo.

En su juventud, cuando aún vivía en Bilbao, Bambulo era una individualidad desconocida, desconocidísima, y la gente que se lo cruzaba por la calle pensaba "qué buen perro parece» o "qué inteligente y valiente debe de ser", pero no llegaba a oler la verdadera realidad, la verdad de las verdades: que se trataba de una individualidad importante, importantísima, y que pertenecía a una familia extraordinaria, presente en casi todos los acontecimientos de la historia (Atxaga, Las bambulísticas historias de Bambulo. Primeros pasos, 5). 
Además de la hipertextualidad muy presente en la narrativa de los últimos años y que, como hemos comprobado, exige del lector unos conocimientos inexcusables de la tradición literaria para interpretar el discurso, el narrador realiza alusiones a referentes culturales — sociohistóricos, sociolingüísticos, etc.- que deben ser conocidos por el lector para acceder al sentido de la narración. Puesto que esto ocurre en todas las obras que hemos seleccionado, propondremos únicamente los ejemplos más destacables. En lo que concierne al primer bloque distinguido en el corpus, podemos referirnos a la narración que lleva por título Matrioska, de Inkiow, narración que explica cómo nacieron las muñecas rusas que todos conocemos por ese nombre. En el cuento titulado Nochebuena, que pertenece a la obra Sapo y Sepo, un año entero, de Lobel, existen también referencias a la Navidad y a las celebraciones propias de esas fechas que el lector debe conocer para comprender el discurso. En el mismo bloque, en el ámbito sociolingüístico, podemos aludir a un ejemplo ya estudiado como es el de Perro y gato, narración en la que subyace la expresión "llevarse como el perro y el gato» o a un cuento más sorprendente en cuanto a su comprensión por el destinatario como es el de La esquina, perteneciente al conjunto de narraciones Sapo y Sepo, un año entero de Lobel. En este último, Sapo cuenta una historia a Sepo acerca de la primavera. En verdad, el cuento se basa en el juego que se establece entre el significado literal y figurado de la frase «estar a la vuelta de la esquina»:

\footnotetext{
-Cuando yo era pequeño, no mucho mayor que un renacuajo — dijo Sapo-, mi padre me dijo: «Hijo, hoy es un día frío y gris, pero la primavera está a la vuelta de la esquina».

Yo quería que llegara la primavera. Salí afuera para encontrar esa esquina. Caminé por un sendero del bosque hasta que llegué a una esquina. Di la vuelta a la esquina para ver si la primavera estaba al otro lado (Lobel, La esquina, en Sapo y Sepo, un año entero: 22-23).
}

En el bloque siguiente - a partir de 8 años-, encontramos un ejemplo destacable en ¡Qué asco de bichos!, de Dahl, obra en la que se solicita del lector el conocimiento de los referentes culturales concernientes a los animales que allí aparecen. Mención aparte merece la narración de Lalana titulada Te quiero, Valero en la que las referencias a la cultura zaragozana y aragonesa constituyen la base del humor de la historia. Así el dragón se llama Valero, en honor del patrón de Zaragoza, o Ángel o Lorenzo, en honor de los patrones de Teruel y Huesca, respectivamente. 
En lo que respecta a las obras dirigidas a receptores mayores de 10 años, ejemplos como el de La abuela de Härtling pueden confirmar la presencia de esos referentes socioculturales que el lector debe identificar. En esta obra, existen pasajes en los que es necesario conocer algunos entresijos administrativos para entender la situación:

Así que la solicitud seguía su curso legal, como suele decirse. Más que seguir su curso legal lo que hacía, en realidad, era arrastrarse por los despachos. La abuela necesitaba el permiso para que le concedieran el subsidio de orfandad de Karli. Y eso, para ella, era importante, porque la abuela, al fin y al cabo era pobre y Karli — según decía ella— se la estaba comiendo viva (Härtling, La abuela: 23-24).

En este mismo bloque, se encuentra una obra en la que el lector debe compartir referentes socioculturales con el narrador. Nos referimos a Manolito Gafotas, obra en la que el espacio y el tiempo en que se inscribe la acción resultan factores decisivos en la interpretación de la obra. Manolito es un niño que vive en Carabanchel, con lo que ello implica:

En mi barrio, que es Carabanchel, hay de todo, hay una cárcel, autobuses, niños, presos, madres, dogradictos y panaderías, pero no hay cuernos para las trencas; así que mi abuelo Nicolás y yo cogimos el metro para ir al centro (Lindo, Manolito Gafotas: 14).

Sólo esta localización explica alusiones como la que viene a continuación:

Y nos lo dijo cuando estábamos esperando a que nos recibiera la psicóloga del colegio, a que nos recibiera uno a uno, porque a los tres juntos no nos aguanta nadie, porque de aquí a tres años lo más tardar vamos a acabar siendo unos delincuentes. Eso no lo digo yo, lo dice mi sita Asunción que además de maestra es futuróloga porque ve el futuro de todos sus alumnos (Lindo, Manolito Gafotas: 26).

En esta obra las alusiones a los medios de comunicación, a la publicidad, a las preocupaciones sociales, etc., son constantes:

Igual que yo me merezco que mi abuelo me llame: Manolito, el Nuevo Joselito. Porque mi abuelo me enseñó su canción preferida, que se llama Campanera, y que es una canción muy antigua, de cuando no había wáter en la casa de mi abuelo y la televisisón era muda. Algunas noches jugamos a Joselito, que era el niño antiguo que la cantaba en el pasado, y yo le canto la canción y luego hago que vuelo y esas cosas, porque si no jugar a Joselito, una vez que acabas 
de cantar Campanera, se convierte en un rollo repollo. Además, a mi abuelo se le saltan las lágrimas por lo antigua que es Campanera y porque el niño antiguo acabó en la cárcel (Lindo, Manolito Gafotas: 11).

Mi abuelo, que acababa de llegar, dijo:

-Esto lo tenía que haber visto Alfred Hitchcock para hacer Los Pájaros. Segunda parte (Lindo, Manolito Gafotas: 108).

En ocasiones, las alusiones se refieren a la propia comunicación literaria, tal como ocurre en Me importa un comino el rey Pepino de Nöstlinger, obra en la que el narrador sigue la estructura marcada por el profesor de lengua:

\author{
CAPÍTULO SEXTO O N. ${ }^{\circ} 6$ \\ SEGÚN LA ESTRUCTURA DEL PROFESOR DE LENGUA \\ Trato de explicar cómo están las cosas entre Haslinger y yo y por qué el asun- \\ to es tan deseperado. Como es tan complicado y tan dificil, voy a necesitar un capi- \\ tulo entero (Nöstlinger, Me importa un comino el rey Pepino: 45). \\ CAPÍTULO DÉCIMO O N.o 10 \\ SEGÚN LA ESTRUCTURA DEL PROFESOR DE LENGUA \\ Voy hasta el fondo del asunto. El fondo estapá muy profundo. Los viejos \\ juguetes de playa de Nik resultan imprescindibles. (En el verdadero sentido de la \\ palabra: Que ahora no se puede prescindir otra vez de ellos) (Nöstlinger, Me \\ importa un comino el rey Pepino: 70).
}

En definitiva, el narrador, a través de las suposiciones que realiza va construyendo la imagen del narratario del lector textual como instancia enunciativa del discurso.

Hasta ahora hemos propuesto cómo los diferentes narradores van creando la imagen de su narratario, unas veces más individualizado, otras veces en el camino de la coincidencia con el lector textual, a través de un proceso de suposiciones que solicitan del destinatario su colaboración.

\title{
3.4.3. La duplicidad del destinatario
}

Para comenzar, no está de más recordar algunas declaraciones de autores como Lindo (Argüeso, 2000: 44-51) o Del Amo (Hiriart, 2000) que niegan escribir únicamente para niños:

Yo no elijo a mis lectores, escribo para buenos lectores de tres a noventa y tres años. [...] El criterio del editor es el que fija la edad de los posibles lecto- 
res. Pero como yo recalco siempre, con la fórmula: «A partir de», los cinco, o los diez años, o los que aparezcan en la contraportada. Hacia arriba, no hay tope. Yo discrepo en ocasiones de la edad señalada como mínimo en la contraportada. Más que los años o el nivel de conocimientos, influye la sensibilidad del lector o la experiencia lectora. Sabiendo que cualquier libro literariamente logrado tiene múltiples posibilidades de interpretación y que el lector adulto puede gozar y enriquecerse en la lectura de libros de literatura infantil, sobre todo de cuentos cargados de contenidos simbólicos (Hiriart, 2000: 62-63).

Interesante a este respecto es el paréntesis que introduce Hiriart (2000: 63) aduciendo unas declaraciones de la escritora Rowling, autora de las aventuras de Harry Potter:

«Yo, realmente, no pensé que era un libro para niños. Escribía para mí acerca de cosas que me parecían graciosas, que me gustaban». La crítica añade: «Ha trabajado mucho para entregar a sus lectores historias bien construidas en cada libro». Pienso que no es necesario añadir otra palabra (Hiriart, 2000: 63-64).

Definitivas resultan las palabras que Gómez Cerdá pronunciaba hace ya unos años y que constituyeron una premonición de lo que hemos definido como doble destinatario:

Una obra literaria será más rica cuanto más podamos descubrir aspectos que a primera vista pasaban desapercibidos, cuanto más nos permita profundizar en ella. Una obra tendrá más interés —además de por su calidad literaria- cuanto más rico y complejo sea lo que en ella se expresa.

El hablar de cosas serias, de cosas importantes, se olvida a menudo en la literatura infantil — también en la literatura en general-y nos encontramos con libros que no pasan de ser anecdóticos.

Es difícil interesar a niños y adultos, a la vez, pero ésta debería ser una meta de la nueva literatura infantil (cit. por Sáiz Ripoll, 1991: 56).

Uno de los aspectos que en la actualidad más preocupa a la crítica es la consideración de la calidad de los libros ofrecidos a la infancia. Ante la ingente cantidad de publicaciones, es necesario establecer unos criterios que permitan discriminar los «buenos libros» de los de peor calidad, la «literatura canónica» (Shavit, 1986) de la que no lo es. Sin duda, es el adulto el que sanciona este tipo de literatura que, en principio, sólo en principio, no está dirigida a este tipo de lector. Esto supone una contradicción que construye la base del discurso literario infantil de nuestros días. Los autores deben crear obras que estén dirigidas a la infancia y que, al mismo tiempo, obtengan el beneplácito de los adultos. Es decir, hay que 
satisfacer las exigencias de dos tipos de lectores muy diferentes en lo que concierne a necesidades y competencia. No es, en este sentido, extraño leer fragmentos como el que se presenta a continuación:

Escribir corto y conciso es una necesidad para seducir a los niños-lectores de la cultura publicitaria de la tele. Un buen libro para niños es también un texto y un texto que fluye bien. Si usted comienza a leer uno y no consigue «engancharse», si se siente tentado a simplificar, a explicar, cambiar las palabras, acortar... entonces elija otro porque a los niños no les gusta la improvisación. Quieren escuchar las mismas expresiones, el mismo ritmo de las frases en cada lectura (Delahie, 1998: 114; cit. por Ruiz Campos, 2000: 40).

Así pues, los propios críticos se hacen eco de ese doble destinatario: si un libro no satisface al adulto, no lo "engancha», no es un libro bueno para el niño. El discurso literario infantil está sujeto a la valoración de los adultos, tal como muestra el procedimiento de evaluación de libros infantiles, según el protocolo de la Unesco presentado por Ruiz Campos (2000: 4247). En este procedimiento diseñado por la Unesco aparecen reseñados los siguientes items:

TíTulo. Propiedad del mismo.

Edición. Cuanto más reciente sea, mejor reflejará la sociedad en la que vive el receptor.

CONTENIDO

A. Materia de lectura

- Se basa en experiencias, intereses y necesidades de significación vital para los niños.

— Estimulación de las actividades de los niños.

- Relación con las actividades de la comunidad.

- No se observan elementos discriminatorios y sexistas.

- Tiene otros elementos fundamentales: sorpresa, sentido del humor, brevedad, diálogo, novedad.

- Fomenta la convivencia humana.

- Sugiere ideales de vida.

- Desarrolla y estimula la higiene mental.

- Cómo facilita la enseñanza del contenido. 
B. Organización del contenido

— Está organizado en unidades o centros de interés.

— Tiene desarrollo psicológico.

C. Vocabulario

- Se expresan las ideas con claridad.

- Hay secuencia lógica en el desarrollo de las ideas.

- Tiene estilo conversacional y natural. Oralidad.

- Apela a lo sensorial.

- Tiene belleza.

E. Objetivos

- Cumple con los objetivos de lectura de la época actual.

ASPECTO MeCÁNICO

A. Cubierta

- Tiene color brillante.

- Tiene tamaño conveniente.

B. Ilustraciones

- Son suficientes.

- Están relacionadas con el material de lectura. ¿¿Aportan contenido al texto?

— Sugieren acción y movimiento.

- Tienen colores adecuados.

- Dan la sensación de la época o ambiente que describen.

- Requieren la imaginación del niño.

C. Impresión

— Tienen tipos adecuados.

- Las líneas tienen longitud apropiada.

- Las oraciones están divididas en frases.

— Tiene márgenes adecuados.

D. Encuadernación

— Es duradero. Está bien cosido.

E. Papel

- Es grueso y duradero. 
Todos los aspectos reflejados en esta tabla de valoración desempeñan un papel de especial relevancia en el discurso que hemos estudiado. Sin embargo, es necesario destacar que el reflejo es meramente relativo, puesto que se prescinde, en gran medida, del valor literario del discurso. Una vez más corremos el riesgo de valorar los libros infantiles sólo por lo que exponen y no por cómo lo exponen. La función educativa que facilitó en el siglo XVIII (cf. Colomer, 1998: 134) la aceptación social del libro dedicado a los niños sigue imperando en evaluaciones como la que acabamos de exponer. Como ya hemos expuesto en los comienzos de este trabajo, la función literaria se ha ido abriendo paso en las creaciones dedicadas a los niños, de tal manera que en la actualidad los críticos intentan defenderla en detrimento de la omnipresencia de la función educativa. Buen ejemplo de ello es gran parte de las obras que componen el corpus seleccionado. No queremos decir con esto que la función educativa haya sido relegada sino que no se le confiere la importancia de antaño. De este modo, algunos autores, como Shavit (1986), han denominado «literatura canónica» infantil a aquella literatura que cumple con las dos funciones tradicionales que desde los tiempos de Horacio recibieron el nombre de enseñar y deleitar - delectare y docere-. En última instancia, quien sanciona la calidad de las obras infantiles es el adulto. Sin embargo, lo que no siempre se tiene en cuenta en las consideraciones que acabamos de exponer es que el discurso, además de cumplir con la adecuación al destinatario infantil, debe también agradar al adulto. No estamos hablando únicamente de la mediación, labor fundamental, sino del deleite del propio adulto.

Algunos autores (Shavit, 1986; Wall, 1991, entre otros) han señalado que el estatus ambivalente del destinatario propio de este discurso define la especificidad del discurso literario infantil frente al discurso literario dirigido a los adultos. Éste es, sin lugar a dudas, el principal motor de innovación de la literatura que estamos estudiando. No negamos, sin embargo, que esta característica haya de contemplarse en el marco de una dinámica de cambios más general, cambios en los que la literatura para adultos parece exportar modelos periclitados, tal como señala Colomer (1998: 139). Como hemos mencionado en el transcurso de estas páginas, la narrativa infantil ha creado sus propios modelos literarios independientemente de los que aparecen en la literatura para adultos, quizá para atraer a los niños al mundo de la literatura en directa competencia con fenóme- 
nos culturales como la televisión, los videojuegos o el cine, fenómenos que, por otra parte, han influido en el discurso literario infantil.

Sea como fuere, lo que nos interesa en este apartado es destacar la duplicidad de destinatarios en el discurso que estamos estudiando. El lector textual o modelo construido por este discurso es doble y contribuye a marcar sobremanera las diferencias entre la narrativa infantil y la narrativa para adultos. No vamos a entrar en definir cuáles son los rasgos propios de este lector textual, ${ }^{38}$ sino que vamos a subrayar, a manera de resumen, los aspectos enunciativos que nos hacen inferir esta doble recepción que condiciona el discurso narrativo infantil desde el principio hasta el final. En lo que concierne a los paratextos, tal como se ha estudiado en el capítulo anterior, es necesario distinguir entre los sistemas no verbales y lo que se denomina peritexto editorial. La ilustración, su presencia y las vías de experimentalidad que ésta ha abierto son elementos dignos de comentario.

Los libros infantiles de los últimos años han incorporado la imagen a la construcción del discurso, de tal forma que sólo a través de la conjunción de texto e ilustración el receptor puede interpretar la obra, basada, en la mayor parte de los casos, como ya se ha expuesto, en la sugerencia conjunta de los dos códigos. Por otra parte, la imagen ha incorporado las tendencias pictóricas del momento construyendo así un producto atractivo visualmente tanto para el adulto como para el niño. Las ediciones cada vez son más cuidadas, lo cual atrae a los coleccionistas adultos en algunos casos. Los aspectos materiales de la edición, además, buscan satisfacer a ese doble receptor desde la sugerencia de obras en las que el niño es acompañado por el adulto como mediador y como receptor en segundo grado (Viala, 1987).

En lo que concierne al peritexto editorial, las informaciones van dirigidas al adulto sancionador, tanto en prólogos como en contracubiertas y en catálogos de las editoriales. De este modo, el lector textual o modelo en su vertiente adulta introduce la impronta en la concepción de las obras analizadas. El peritexto editorial adquiere, en este sentido, mayor importancia en la narrativa infantil que la que presenta en la narrativa para adultos.

38 Cf. a este respecto Lluch, 1998. 
En lo que respecta a las instancias de autor textual, narrador y narratario y lector textual, se establece una comunicación interna entre narrador y narratario, de tal manera que el narrador cuenta, en algunos casos, únicamente con el narratario como instancia textual que se identifica con el receptor infantil y atiende la presencia de un receptor adulto que se materializa en el lector textual. En los casos en los que el narratario ignora parte de la información que el autor dedica al lector textual se establece una lectura "por encima» que se refleja claramente en la presencia de la ironía como estrategia textual. El lector textual, por otra parte, como ha quedado expresado de una manera insistente, aglutina tanto al receptor infantil como al adulto que realiza las veces de mediador y, por tanto, de receptor como estrategia generadora del discurso. Esta duplicidad constituye, sin duda, una de las causas por las que el discurso narrativo infantil ha ido acuñando modelos propios, diferenciados de los propuestos desde la literatura para adultos. 


\section{CODA}

Nuevas y viejas formas de contar, nuevos y viejos contadores, nuevos y viejos "contados», porque el receptor de los umbrales del siglo XXI es un receptor que nace al son de los ecos de la tradición oral para aproximarse con naturalidad a un discurso imbuido de las notas de la sociedad en la que se desarrolla.

La contemplación, pues, del texto en el interior del acto de la comunicación, tratando de este modo al receptor y el contexto de producción del mismo, nos acerca a un discurso marcado por la existencia de un destinatario diferente del que presume la literatura para adultos, un receptor que incluye a este último y al niño; en definitiva, un lector textual definido por la duplicidad y la ambivalencia. Por otra parte, este lector que inicia el siglo XXI corresponde a las condiciones propias de una sociedad posindustrial, democrática, inserta en un marco legal que ha proporcionado un sistema de educación obligatorio, una sociedad en la que las lecciones ya no tienen demasiado sentido porque todo resulta relativo, una sociedad en la que los medios audiovisuales imprimen nuevos modos de aproximación a los mensajes.

Así pues, las formas de contar han ido evolucionando y se han adaptado al nuevo milenio. El contador tradicional ha sido sustituido por la ilustración; las recepciones ya no son colectivas sino individuales; los autores no sólo son los escritores sino también los ilustradores; la imagen presta nuevos cauces a la creación; y los valores educativos marcan la línea temática de parte de las obras, generando, en ocasiones, un discurso explícitamente didáctico. Bien es verdad que, por otra parte, comienza a despuntar un discurso más arriesgado, con nuevas propuestas y, sobre todo, con mayor confianza en la competencia del receptor. 
Desde la perspectiva paratextual, la imagen desempeña un papel decisivo en las dos últimas décadas. El álbum se muestra como la clase de libro que mejor se adentra en las líneas de innovación a los que obliga la presencia del doble destinatario. Así, el texto camina sin las constricciones de antaño, cediendo a la ilustración un lugar de honor en el universo de la interpretación.

Sorprende, sin embargo, cómo un discurso que se manifiesta menos supeditado a la función educativa vierte la mayor parte de ese didactismo soterrado en el aparato peritextual que no deja de obedecer, en algunos casos, a las exigencias de un mercado en el que el libro se contempla como producto editorial dependiente de las necesidades docentes.

En fiel correspondencia a estas características, este discurso que solicita cada vez más la participación del lector como estrategia textual, opta por un narrador que se aleja de la omnisciencia tradicional para dejar paso a uno más proclive al juego textual.

Así pues, comienzan a aparecer narradores no tan «sabedores», preferentemente autodiegéticos, que, en principio, son menos fiables que los tradicionales puesto que poseen menos información. De este modo, los relatos focalizados internamente en los protagonistas infantiles son bastante habituales ya que implican una potenciación de la perspectiva sobre el contenido de la narración que se muestra de vital importancia por la presencia de la psicologización de los conflictos como línea argumental desarrollada desde el distanciamiento.

En definitiva, el narrador que controla el mensaje y lo mediatiza, tan característico de otras épocas, va dejando las riendas a un narrador menos informado que potencia la focalización interna y externa de la narración, que establece "huecos vacíos», en espera de que el narratario los «rellene» a través de las claves textuales; un narrador que se distancia de lo narrado declinando parte de su responsabilidad en el autor textual. El didactismo rígido y explícito, propio de otros tiempos, ya no se centra en el narrador sino que se diluye, en el peor de los casos, en la presencia de otras instancias enunciativas que resultan menos agresivas para la calidad literaria de la obra.

La ironía que emana de muchos de los discursos que hemos analizado, y que atrae sobremanera al receptor adulto, solamente se puede justi- 
ficar desde el punto de vista discursivo por medio de la complicidad que se establece entre autor/autor textual y lector textual que superan la relativa ignorancia de las instancias enunciativas de narrador y narratario. Así se justifica el deleite del adulto ante la lectura de obras dirigidas, en principio, al receptor infantil. Esta duplicidad permite, asimismo, los diferentes juegos transtextuales característicos de las últimas décadas.

Caminamos, pues, en los umbrales del siglo XXI hacia un discurso literario más arriesgado en sus propuestas, más innovador en las realizaciones, que incorpora modelos de la literatura para adultos y que acuña los propios en aras de un receptor doble que le es característico. Múltiples son, sin embargo, los factores que pueden frenar este desarrollo, desde el mercado editorial o el descuido de la educación literaria hasta la necesidad de orientar y de enseñar de una forma explícita a un receptor en el que no se acaba de confiar. El futuro parece apostar por la calidad literaria, por la creación de lectores competentes, al menos en parte de lo que hoy se muestra al lector del nuevo siglo. Eso sí, existe otro tipo de oferta, quizá más rentable, que no augura unos tiempos tan saludables. Pero, esa es otra historia... 


\title{
ANEXO \\ DISTRIBUCIÓN POR EDADES \\ DE OBRAS MENCIONADAS
}

\author{
Desde 5 hasta 8 años ${ }^{1}$ \\ Ahlberg, A., y J. Ahlberg, ;Adiós, pequeño! \\ Ahlberg, A., y J. Ahlberg, El cartero simpático. \\ Alcántara, R., y Gusti, ;Huy, qué miedo! \\ Alcántara, R., y Gusti, Perro y gato. \\ Asensio, G., y M. Company, La escoba de la bruja. \\ Balzola, A., Munia y el cocolilo naranja. \\ Balzola, A., Munia y la luna. \\ Browne, A., El túnel. \\ Calatayud, M., El pie frito. \\ Cano, C., y P. Giménez, iiiPapááá...!!!! \\ Capdevila, R., Las nuevas historias de la bruja aburrida. \\ Cole, B., El libro apestoso. \\ Cole, B., Lo malo de mamá. \\ Company, M., La historia de Ernesto. \\ Company, M., y R. Capdevila, Las tres mellizas. \\ Cooper, H., Ha sido el pequeño monstruo. \\ Corentin, Ph., iPapá! \\ Cortés, J. L., y Avi, Un culete independiente. \\ Cousins, L., La casa de Maisy. \\ Da Coll, I., Pies para la princesa.
}

1 En este bloque, la doble recepción es clara. Por tanto, la etiqueta cronológica sólo marca el inicio en la recepción. 
Dautremer, R., Enamorados.

Domitille, y J. O. Héron, El libro que tenía un agujero.

Ende, M., y A. Fuchsuber, El tragasueños.

Faulkner, K., y N. Spender, Bromas de animales.

Grejniec, M., A qué sabe la luna.

Inkiow, D., y R. Rius, Matrioska.

Inkpen, M., ¿Dónde está el osito de Kiper?

Inkpen, M., Juega al escondite con el cerdito Wibbly.

Jandl, E., y N. Jung, Ser quinto.

Kitamura, S., Cuando los borregos no pueden dormir.

Kitamura, S., Por el hilo se saca el ovillo.

Lairla, S., y A. Lartitegui, La carta de la señora González.

Lalana, F., Te quiero, Valero.

Larrondo, V., y C. Desmarteau, Mamá fue pequeña antes de ser mayor.

Lobel, A., Historia de ratones.

Lobel, A., Días con Sapo y Sepo.

Lobel, A., Sapo y Sepo, inseparables.

Lobel, A., Sapo y Sepo, un año entero.

Machado, A. M., Niña Bonita.

Mari, I., El erizo de mar.

Martínez i Vendrell, M., y C. Solé Vendrell, Yo las quería.

Mateos, P., La bruja Mon.

Mateos, P., Quisicosas.

McKee, D., No quiero el osito.

McKee, D., Ahora no, Fernando.

McKee, D., El libro sorpresa de Elmer.

Minarik, E. H., La visita de Osito.

Minarik, E. H., Osito.

Minilibros para soñar (Carballeira, P., y B. Barrio, Paco; Méndez, R., y O. Villán, Los dos jorobados).

Monreal, V., y F. Lalana, El lobo feroz.

Monreal, V., y F. Lalana, Pelotieso y Ricitos de Oro.

Paola, T. de, Oliver Button es un nena.

Piérola, M., No sé.

Puncel, M., y N. López, Barquichuelo de papel.

Rapapport, G., 10 soldados.

Romances, introducción de A. Pérez Lasheras. Ilustración de D. Guirao.

Sáez Castán, J., Los tres erizos.

Sendak, M., Donde viven los monstruos.

Sierra, J., y M. Piérola, El soldado y la niña.

Stevenson, J., No nos podemos dormir. 
Stilton, G., El libro de la paz.

Teulade, P., y J. C. Sarrazin, Porque te quiero...

Ungerer, T., El sombrero.

Varvasovszky, L., Los osos de Ni-se-sabe.

Vaugelade, A., De cómo Fabián acabó con la guerra.

Ventura, A., y P. Amargo, No todas las vacas son iguales.

Ventura, A., y P. Amargo, Osos de cuento.

Waddell, M., y B. Firth, Tú y yo, osito.

Wells, R., jJulieta, estáte quieta!

Wells, R., La estupenda mamá de Roberta.

Wishinsky, F., y C. Thompson, Onga Bonga.

Young, E., Siete ratones ciegos.

\section{A partir de 8 años}

Alonso, F., El hombrecito vestido de gris y otros cuentos.

Armijo, C., Los batautos.

Atxaga, B., Nikolasa: aventuras y locuras.

Baquedano, L., Fantasmas de día.

Bermejo, V., y M. Gallardo, Cuentos sólo para niñas.

Bermejo, V., y M. Gallardo, Cuentos sólo para niños.

Cela, J., El ladrón de sombras.

Cleary, B., Ramona empieza el curso.

Company, M., La reina calva.

Company, M., Mi hermano mayor.

Dahl, R., iQué asco de bichos!

Dahl, R., Cuentos en verso para niños perversos.

Farias, J., Algunos niños, tres perros y más cosas.

Innocenti, R., Rosa Blanca.

Mahy, M., El secuestro de la bibliotecaria.

Martín, M. T., Yo vivi con una bruja.

Matute, A., El saltamontes verde.

Muñoz Martín, J., Fray Perico y su borrico.

Nesquens, D., y E. Urberuaga, Diecisiete cuentos y dos pingüinos.

Nesquens, D., y A. Gamón, Operación J.

Nöstlinger, C., Querida abuela, tu Susi.

Obiols, M., y M. Calatayud, Libro de las M'Alicias.

Obiols, M., jAy Filomena, Filomena! y otros cuentos.

Sommer-Bodenburg, A., Si quieres pasar miedo.

Vázquez-Vigo, C., Caramelos de menta.

Yeoman, J., La rebelión de las lavanderas. 


\section{A partir de 10 años}

Alonso, S., El grito de la grulla.

Atxaga, B., Las bambulisticas historias de Bambulo. Primeros pasos.

Atxaga, B., Memorias de una vaca.

Barrena, P., ; Que me parta un rayo!

Bliesener, K., Las aventuras de los detectives del faro.

Carroll, L., Alicia en el pais de las maravillas.

Company, M., Mi hermano mayor.

Dahl, R., Charlie y la fábrica de chocolate.

Dahl, R., Danny, campeón del mundo.

Dahl, R., Las brujas.

Dahl, R., Matilda.

Ende, M., Momo.

Farias, J., Los apuros de un dibujante de historietas.

Farias, J., Años difíciles.

Gómez Cerdá, A., El cuarto de las ratas.

Goscinny, R., El pequeño Nicolás.

Gripe, M., Elvis Karlsson.

Härtling, P., Ben quiere a Anna.

Härtling, P., La abuela.

Kafka, F., La metamorfosis, ilustraciones de Scafati.

Kurtz, C., Veva.

Las mil y una noches, ilustraciones de Serrano, Ranucci, Arguilé, Riera y Odriozola.

Lindo, E., Manolito Gafotas.

Mendo, M. A., El vendedor de agujeros.

Molina, M. I., De Victoria para Alejandro.

Morpurgo, M., El león mariposa.

Moure, G., El beso del Sáhara.

Nesquens, D., y E. Arguilé, Hasta (casi) cien bichos.

Nöstlinger, C., Konrad o el niño que salió de una lata de conservas.

Nöstlinger, C., Me importa un comino el rey Pepino.

Osorio, M., Romanies.

Press, H. J., Aventuras de "La mano negra».

Puente, L. A., y F. Lalana, Hubo una vez otra guerra.

Rodari, G., El planeta de los árboles de Navidad.

Saunders, S., La torre de Londres.

Sommer-Bodenburg, A., El pequeño vampiro.

Steer, D., y P. Ludlow, Hadas malvadas.

Stevenson, R. L., La isla del tesoro.

White, E. B., Las telarañas de Carlota. 


\section{BIBLIOGRAFÍA}

\section{Obras de creación mencionadas}

Ahlberg, A., y J. Ahlberg (1982a), jAdiós, pequeño!, Madrid, Altea (col. Altea Benjamín). [Trad. de Bye Bye, Baby, 1986.]

- y J. Ahlberg (1982b), ;Qué risa de huesos!, Madrid, Altea (col. Altea Benjamín). [Trad. esp. de Funnybones, 1980.]

- y J. Ahlberg (1991), El cartero simpático, Barcelona, Destino. [Trad. de The Jolly Postman, 1986.]

- y J. Ahlberg (1992), El cartero simpático en Navidad, Barcelona, Destino. [Trad. de The Jolly Christmas Postman, 1991.]

AlCÁNTARA, R. (1992), ;Huy, qué miedo!, Barcelona, Edebé, 2. a ed. [Ilustraciones de Agustín Asensio (Gusti). Serie Tucán.]

- y Gusti (1998), Perro y gato, Barcelona, La Galera.

Alonso, F. (1997), El hombrecito vestido de gris y otros cuentos, Madrid, Alfaguara, 1. ${ }^{\text {a ed., 7. }}{ }^{\text {a }}$ reimpr. [Ilustraciones de U. Wensell.]

Alonso, S. (2003), El grito de la grulla, Zaragoza, Edelvives. [Ilustraciones de T. Gatagán.]

Armijo, C. (1983), Los batautos, Valladolid, Miñón. [Ilustraciones de M. Balaguer.]

Asensio, G., y M. COMPANy (1990a), Nana Bunilda come pesadillas, Madrid, SM.

- y M. Company (1990b), La escoba de la bruja, Madrid, SM.

AtXagA, B. (1989), Nikolasa: aventuras y locuras, Barcelona, Ediciones B (col. Mar Abierto: 21). [Ilustraciones de J. C. Eguillor.]

- (1992), Memorias de una vaca, Madrid, SM.

- (1998), Las bambulísticas historias de Bambulo. Primeros pasos, Madrid, Alfaguara. [Ilustraciones de M. Valverde.]

Balzola, A. (1982a), Munia y el cocolilo naranja, Barcelona, Destino.

- (1982b), Munia y la luna, Barcelona, Destino.

Baquedano, L. (1997), Fantasmas de dia, Madrid, SM (col. El Barco de Vapor), 19. a ed. [Ilustraciones de T. Gatagán.] 
Barrena, P. (1991), ¡Que me parta un rayo!, Barcelona, Edebé. (col. Periscopio: 4). [Ilustraciones de L. Bernal.]

Bermejo, V., y M. Gallardo (2004a), Cuentos sólo para niñas, Barcelona, El Aleph.

- y M. Gallardo (2004b), Cuentos sólo para niños, Barcelona, El Aleph.

BLIESENER, K. (1986), Las aventuras de los detectives del faro, Madrid, Espasa (col. Espasa Juvenil: 64). [Trad. de Schumuggler auf der Fähre y Alter Trödel, faule Tricks, 1980.]

Browne, A. (1999), El túnel, México, Fondo de Cultura Económica.

Calatayud, M. (2004), El pie frito, Alicante, Ediciones de Ponent.

CANo, C., y P. Giménez (1999), iiiPapááá...!!!, Madrid, Anaya.

CAPDEVILA, R. (1999), Las nuevas historias de la bruja aburrida. Cuando era peque$\tilde{n} a$, Barcelona, Salvat.

CARroll, L. (2000), Alicia en el país de las maravillas, Barcelona, Lumen.

CELA, J. (1990), El ladrón de sombras, Madrid, SM (col. Catamarán: 21), 3. a ed. [Ilustraciones de Lluïsot. Trad. de El lladre d'ombres, 1989.]

CleARY, B. (1997), Ramona empieza el curso, Madrid, Espasa-Calpe, 7. a ed. [Ilustraciones de A. Tiegreen. Trad. de Ramona Quimby, age 8, 1981.]

Cole, B. (1988), Lo malo de mamá, Madrid, Altea (col. Altea Benjamín). [Trad. de The trouble with Mum, 1983.]

- (1994), El libro apestoso, México, Fondo de Cultura Económica.

Company, M. (1985), Mi hermano mayor, Barcelona, La Galera. [Ilustraciones de F. Rovira. Trad. de El germà gran, 1985.]

- (1988), La reina calva, Madrid, SM (col. El Barco de Vapor: 135). [Ilustraciones de M. Arànega. Trad. de La reina Calba, 1988.]

- (1990), La historia de Ernesto, Madrid, SM (col. El Barco de Vapor: 105), 5. ${ }^{a}$ ed. [Ilustraciones de J. M. Lavarello. Trad. de La història de l'Ernest, 1985.]

- y R. Capdevila (1986), Las tres mellizas y la Cenicienta, Barcelona, Arín. [Trad. de Les Tres Bessones i la Ventafocs, 1986.]

COOPER, H. (1999), Ha sido el pequeño monstruo, Barcelona, Juventud. [Trad. de Little Monster did it!, 1995.]

Corentin, Ph. (1999), ¡Papá!, Barcelona, Corimbo. [Trad. de Papa!, Paris, L'École des Loisirs, 1995.]

Cortés, J. L. y Avi (1992), Un culete independiente, Madrid, SM (colección Los Piratas).

Cousins, L. (1995), La casa de Maisy, Barcelona, Serres.

DA Coll, I. (2002), Pies para la princesa, Madrid, Anaya.

DAHL, R. (1990), Matilda, Madrid, Alfaguara, 1. ${ }^{\mathrm{a}}$ ed., 2..$^{\mathrm{a}}$ reimpr. [Ilustraciones de Q. Blake. Trad. de Matilda, 1988.]

- (1991), Las brujas, Madrid, Alfaguara (col. Alfaguara Juvenil: 147), 12. ${ }^{a}$ reimpr. [Ilustraciones de Q. Blake. Trad. de The Witches, 1983.] 
DAHL, R. (1993a), ¡Qué asco de bichos!, Madrid, Alfaguara. [Ilustraciones de Q. Blake. Trad. de Dirty Beats, 1978.]

- (1993b), Danny el campeón del mundo, Madrid, Alfaguara, 4.a reimpr. [Ilustraciones de J. Bennett. Trad. de Danny the Champion of the World, 1975.]

- (1995a), Charlie y la fábrica de chocolate, Madrid, Alfaguara (col. Alfaguara Juvenil), 1.a ed., 34. ${ }^{a}$ reimpr. [Ilustración de F. Jacques. Trad. de Charlie and the Chocolat Factory, 1975.]

- (1995b), Cuentos en verso para niños perversos, Madrid, Altea (col. Altea Benjamín). [Ilustraciones de Q. Blake. Trad. de Revolting rhymes, 1982.]

DAUTREMER, R. (2003), Enamorados, Madrid, Kókinos.

Domitille, y J. O. Héron (2002), El libro que tenía un agujero, Barcelona, Lumen.

Ende, M. (1996), Momo, Madrid, Alfaguara (col. Alfaguara Juvenil: 15). 1. ${ }^{a}$ ed., 48. ${ }^{a}$ reimpr. [Trad. de Momo, 1973.]

- y A. Fuchsuber (1980), El tragasueños, Barcelona, Edigraf. [Trad. de Das Traumfresserchen, 1978.]

FARIAS, J. (1981), Algunos niños, tres perros y más cosas, Madrid, Espasa, 2. ${ }^{a}$ ed. [Ilustraciones de A. Lobato.]

- (1983), Años difíciles, Valladolid, Miñón. [Ilustraciones de R. Díaz.]

- (1988), Los apuros de un dibujante de historietas, Madrid, Bruño (col. Altamar). [Ilustraciones de J. R. Alonso.]

FAULKNER, K., y N. SPENDER (1999), Bromas de animales, Madrid, SM. [Trad. de What do you call a gorilla with a banana in each ear?, 1999.]

GÓMez CerdÁ, A. (1998), El cuarto de las ratas, Madrid, SM (col. El Barco de Vapor: 105).

GoscinNY, R. (1985), El pequeño Nicolás, Madrid, Alfaguara (col. Alfaguara Juvenil: 161). [Ilustraciones de J. Sempé. Trad. de Le petit Nicolas, 1960.]

Grejniec, M. (1999), A qué sabe la luna, Pontevedra, Kalandraka.

GrIPE, M. (1994), Elvis Karlsson, Madrid, Alfaguara (col. Alfaguara Juvenil: 18). [Ilustraciones de H. Gripe. Trad. de Elvis Karlsson, 1972.]

HärTling, P. (1986), Ben quiere a Anna, Madrid, Alfaguara (col. Alfaguara Juvenil: 49). [Ilustraciones de S. Brandes. Trad. de Ben liebt Anna, 1984.]

- (2000), La abuela, Madrid, Alfaguara (col. Alfaguara Juvenil: 17). [Ilustraciones de I. Mizsenko. Trad. de Oma, die Geschichte von Kalle, der seine Eltern verliert und von seiner Grossmutter aufgenommen wird, 1975.]

InKiow, D., y R. Rius (1987), Matrioska, Madrid, SM (colección El Barco de Vapor: 18) [Trad. de Die Puppe, die ein Baby haben wollte, Viena-Múnich, Jugend und Volk Verlag, GmbH., 1974.]

INKPEN, M. (1997), Juega al escondite con el cerdito Wibbly, Barcelona, Timun Mas. [Trad. de Everyone hide from Wibbly Pig, 1997.]

- (1998), ¿Dónde está el osito de Kiper?, Barcelona, Grupo Editorial Ceac. Timun Mas, 1984. [Trad. de Where, oh where, is Kipper's bear?, 1984.] 
InNoCenti, R. (2002), Rosa Blanca, Salamanca, Lóguez Ediciones.

JANDL, E., y N. Jung (2002), Ser quinto, Salamanca, Lóguez Ediciones.

KAFKA, F. (2004), La metamorfosis, Barcelona, Hipòtesi. [Ilustraciones de Scafati.] KitAmuRA, S. (1998), Cuando los borregos no pueden dormir, Madrid, Altea, 2. a ed. [Trad. de When Sheep Cannot Sleep, 1986.]

- (1999), Por el hilo se saca el ovillo, Madrid, Altea. [Trad. de Sheep in wolves' clothing, Andersen Press, 1995.]

KurTZ, C. (1994), Veva, Barcelona, Noguer, 15.a ed. [Ilustración de O. Kurtz. 1.a ed., 1980.]

Lairla, S., y A. Lartitegui (2000), La carta de la señora González, México, Fondo de Cultura Económica.

Lalana, F. (1994), Te quiero, Valero, Zaragoza, Diputación General de Aragón. [Ilustraciones de I. Ferrer.]

Larrondo, V., y C. Desmarteau (2001), Mamá fue pequeña antes de ser mayor, Madrid, Kókinos.

Las mil y una noches, Madrid, Anaya, 2001. [Ilustraciones de Serrano, Ranucci, Arguilé, Riera y Odriozola.]

Lindo, E. (1994), Manolito Gafotas, Madrid, Alfaguara (col. Alfaguay). [Ilustraciones de E. Urberuaga.]

Lobel, A. (1978), Historia de ratones, Madrid, Alfaguara (col. Alfaguara Infantil. Álbumes de bolsillo: 12). [Trad. de Mouse Tales, 1972.]

- (1998), Días con Sapo y Sepo, Madrid, Alfaguara (col. Alfaguara Infantil). [Trad. de Days with Frog and Toad, 1979.]

- (1999), Sapo y Sepo, inseparables, Madrid, Alfaguara (col. Alfaguara Infantil). [Trad. de Frog and Toad together, 1971.]

- (2000), Sapo y Sepo, un año entero, Madrid, Alfaguara (col. Alfaguara Infantil). [Trad. de Frog and Toad all year, 1971.]

Machado, A. M.a (2003), Niña Bonita, Caracas, Ekaré.

MaнY, M. (1999), El secuestro de la bibliotecaria, Madrid, Alfaguara (col. Alfaguara Infantil). [Ilustraciones de Q. Blake. Trad. de The Librarian and the Robbers, 1978.]

MARI, I. (1999), El erizo de mar, Madrid, Anaya.

Martín, M.a T. (1995), Yo viví con una bruja, Barcelona, Edebé (col. Tucán: 60). [Ilustraciones de V. Monreal.]

Martínez i Vendrell, M., y C. Solé Vendrell (1984), Yo las quería, Barcelona, Destino. [Trad. de Jo les volia, 1984.]

Mateos, P. (1984), La bruja Mon, Madrid, SM (col. El Barco de Vapor: 9). [Ilustraciones de V. Escrivá.]

- (1988), Quisicosas, Madrid, SM (col. El Barco de Vapor: 138). [Ilustraciones de P. Núnez.] 
MAtute, A. (1994), El saltamontes verde, Barcelona, Lumen, 10. ${ }^{\mathrm{a}}$ ed. [Ilustraciones de M. Piérola, 1972.]

McKee, D. (1984), Ahora no, Fernando, Madrid, Altea (col. Altea Benjamín). [Trad. de Not now, Bernard, 1980.]

- (1986), No quiero el osito, Madrid, Espasa-Calpe. [Trad. de I hate my teddy bear, 1982.]

- (1997), El libro sorpresa de Elmer, Barcelona, Timun Mas. [Trad. de The Elmer pop-up book, 1996.]

Mendo, M. A. (1990), El vendedor de agujeros, Valladolid, Miñón, 3. ${ }^{\text {a ed. [Ilus- }}$ traciones de A. Esteban, 1987]

Minarik, E. H. (1980), Osito, Madrid, Alfaguara, 27. a ed. [Ilustraciones de M. Sendak. Trad. de Little Bear, 1957.]

- (1982), La visita de Osito, Madrid, Alfaguara Infantil, 27. ${ }^{a}$ ed. [Ilustraciones de M. Sendak. Trad. de Little Bear's Visit, 1960.]

Minilibros para soñar, Pontevedra, Kalandraka (P. Carballeira y B. Barrio, Paco; R. Méndez y O. Villán, Los dos jorobados), 2002.

Molina, M. I. (1994), De Victoria para Alejandro, Madrid, Alfaguara (col. Alfaguara Juvenil).

Monreal, V., y F. Lalana (1999a), El lobo feroz, Madrid, Bruño.

- (1999b), Pelotieso y Ricitos de Oro, Madrid, Bruño.

Morpurgo, M. (1998), El león mariposa, León, Everest (col. Montaña Encantada. Serie Naranja). [Trad. de The Butterfly Lion, 1996.]

Moseley, K., y I. Craig (1998), Robinson ratón, Barcelona, Destino. [Trad. de Robinson Mouse, 1997.]

Moure, G. (1998), El beso del Sáhara, Madrid, Alfaguara.

Muñoz Martín, J. (1989), Fray Perico y su borrico, Madrid, SM (col. El Barco de Vapor: 8) 13. a ed. [Ilustración de A. Tello.]

Nesquens, D., y E. Urberuaga (2000), Diecisiete cuentos y dos pingüinos, Madrid, Anaya.

- y E. Arguilé (2001), Hasta (casi) cien bichos, Madrid, Anaya.

- y A. Gamón (2003), Operación J, Valencia, Diálogo.

Nöstlinger, C. (1984), Me importa un comino el rey Pepino, Madrid, Alfaguara (col. Alfaguara Juvenil: 100). [Trad. de Wir pfeifen auf den Gurkenkönig, 1972.]

- (1989), Querida abuela, tu Susi, Madrid, SM (col. El Barco de Vapor: 115), 5. ${ }^{a}$ ed. [Ilustración de C. Nöstlinger Jr. Trad. de Liebe Oma, deine Susi, 1985.]

- (1996), Konrad o el niño que salió de una lata de conservas, Madrid, Alfaguara (col. Alfaguara Juvenil: 25), 2. ${ }^{\mathrm{a}}$ ed., 6. ${ }^{\mathrm{a}}$ reimpr. [Ilustraciones de F. Wittkamp. Trad. de Konrad oder Das Kind aus der Konservenbüchse..., 1975.] 
Obiols, M. (1989), ;Ay Filomena, Filomena! y otros cuentos, Barcelona, Juventud, 4. ${ }^{\mathrm{a}}$ ed. [Ilustraciones de U. Mestre.]

- y M. Calatayud (1990), Libro de las M'Alicias, Madrid, SM (col. Los Ilustrados del Barco de Vapor).

Osorio, M. (1988), Romanies, Madrid, Anaya (col. El Duende Verde: 22). [Ilustraciones de C. Molinos.]

PaOla, T. de (1996), Oliver Button es un nena, Madrid, Susaeta, 6. ${ }^{\mathrm{a}}$ ed. [Trad. de Oliver Button is a Sissy, 1979.]

Pascual, E. (2003), Días de Reyes Magos, Madrid, Anaya. [Ilustraciones de J. Serrano.]

Piérola, M. (1998), No sé, Madrid, SM (col. Los Piratas).

Press, H. J. (1997), Aventuras de "La mano negra», Madrid, Espasa (col. Espasa Juvenil: 21). [Trad. de Die Abenteuer der «schwarzen Hand», 1965.]

Puente, L. A., y F. Lalana (1989), Hubo una vez otra guerra, Madrid, SM.

Puncel, M., y N. López (1996), Barquichuelo de papel, Madrid, Bruño (col. Chiquicuentos).

RAPAPPORT, G. (2003), 10 soldados, Zaragoza, Edelvives.

RODARI, G. (1994), El planeta de los árboles de Navidad, Madrid, SM (col. El

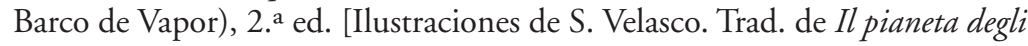
alberi di Natale, 1962.]

Romances, introducción de A. Pérez Lasheras, Zaragoza, Prensas Universitarias de Zaragoza, 2003. [Ilustraciones de D. Guirao.]

Sáez CASTÁn, J. (2003), Los tres erizos, Barcelona, Ekaré.

SAUnders, S. (1987), La torre de Londres, Barcelona, Timun Mas (col. Elige tu propia aventura de El globo Azul. [Ilustraciones de L. Tomei. Trad. de The Tower of London, 1984.]

SendaK, M. (1995), Donde viven los monstruos, Madrid, Altea. [Trad. de Where the Wild Things Are, 1963.]

Sierra, J., y M. Piérola (2003), El soldado y la niña, Barcelona, Destino.

Sommer-BodenburG, A. (1987), Si quieres pasar miedo, Madrid, Espasa (col. Austral Juvenil: 68). [Ilustraciones de H. Spiess. Trad. de Wenn du dich gruseln willst, 1987.]

- (1993), El pequeño vampiro, Madrid, Alfaguara, 1. ${ }^{a}$ ed., 17..$^{a}$ reimpr. [Ilustraciones de A. Genke. Trad. de Der Kleine Vampir, 1979.]

SteER, D., y P. Ludlow (1998), Hadas malvadas, Barcelona, Parramón. [Trad. de Scary Fairies, 1997.]

STEVEnSON, J. (1983), No nos podemos dormir, Madrid, Alfaguara (col. Alfaguara Infantil-Juvenil: 36). [Trad. de We Can't Sleep, 1980.]

Stevenson, R. L. (2003), La isla del tesoro, Barcelona, Hipotèsi. [Ilustraciones de Junceda.]

Stilton, G. (2003), El libro de la paz, Barcelona, Destino. 
Teulade, P., y J. C. Sarrazin (1998), Porque te quiero..., Barcelona, Corimbo. [Trad. de Parce que je t'aime, 1996.]

Ungerer, T. (1978), El sombrero, Madrid, Alfaguara (col. Alfaguara Infantil. Álbumes de bolsillo: 10). [Trad. de The hat, 1970.]

VARVASOvSZKY, L. (1981), Los osos de Ni-se-sabe, Madrid, Altea (col. Altea Benjamín). [Trad. de Das Schneebärenbuch, 1978.]

Vaugelade, A. (2000), De cómo Fabián acabó con la guerra, Barcelona, Corimbo.

VÁzquez-Vigo, C. (1990), Caramelos de menta, Madrid, SM (col. El Barco de Vapor: 15). 15. ${ }^{\mathrm{a}}$ ed.; 1.a ed., 1981.

Ventura, A., y P. Amargo (1999), No todas las vacas son iguales, Caracas, Ediciones Camelia.

- (2002), Osos de cuento, Caracas, Ediciones Camelia.

WadDell, M., y B FirTh (1996), Tú y yo, osito, Barcelona, kókinos. [Trad. de You and me, Little Bear, Walker Books, 1996.]

Wells, R. (1981), jJulieta, estáte quieta!, Madrid, Altea (col. Altea Benjamín). [Trad. de Noisy Nora, 1973.]

- (1995), La estupenda mamá de Roberta, Madrid, Altea.

White, E. B. (1996), Las telarañas de Carlota, Barcelona, Moguer (col. Mundo Mágico: 79). [Ilustraciones de G. Williams. Trad. de Charlotte’s Web, 1980.]

WishinskY, F., y C. ThOMPSON (1999), Onga Bonga, Barcelona, Juventud. [Trad. de Onga Bonga, 1998.]

YeOMAN, J. (1981), La rebelión de las lavanderas, Madrid, Altea. [Ilustraciones de Q. Blake. Trad. de The wild washerwomen, 1979.]

YounG, E. (2003), Siete ratones ciegos, Caracas, Ekaré.

\section{Catálogos}

100 nuevos Barcos de Vapor, Pistas para la lectura y actividades en torno a cada libro, Madrid, El Barco de Vapor, 1990.

2001. Catálogo general, Madrid, Juventud.

Catálogo 2000-2001. Primaria. Contigo creamos lectores, Madrid, Alfaguara.

Catálogo de publicaciones generales. Bruño. 1993, Madrid, Bruño.

Lecturas recomendadas. Educación Infantil. 2004, Madrid, Anaya.

Lecturas recomendadas. Educación Infantil. Curso 2000-2001, Madrid, Anaya.

Lecturas recomendadas. Primaria. Primer ciclo. Curso 2000-2001, Madrid, Anaya.

Lecturas recomendadas. Primaria. Segundo ciclo. Curso 2000-2001, Madrid, Anaya.

Lecturas recomendadas. Primaria. Tercer ciclo. Curso 2000-2001, Madrid, Anaya.

Libros infantiles y juveniles. SM. 2000-2001, Madrid, SM.

Literatura Infantil y Juvenil. Edebé. Catálogo 1993, Barcelona, Edebé.

Literatura Infantil y Juvenil. Noguer crea lectores, Barcelona, Noguer. 
Susaeta ediciones, s. a. Catálogo general de libros 1992, Madrid, Susaeta.

Tendencias, Madrid, Alfaguara, 1992.

\section{Estudios teóricos}

ABBADIE-ClerC, Ch., et al. (1977), Les livres pour les enfants, París, Éditions ouvrières. ABril, M. (2000), «Los libros infantiles pueden enseñar a leer», Cuadernos de Literatura Infantil y Juvenil, núm. 124, pp. 26-31.

Acosta Gómez, L. A. (1989), El lector y la obra, Madrid, Gredos.

ADAM, J. M., y C. U. LORDA (1999), Lingüistica de los textos narrativos, Barcelona, Ariel.

Adams, J.-K. (1985), Pragmatics and Fiction, Amsterdam, Benjamins.

Aguiar E Silva, V. M. de (1997), Teoria da Literatura, Coimbra, Universidad da Coimbra, 8. ${ }^{a}$ ed. [1. ${ }^{a}$ ed. esp. de 1972.$]$

Albanell, P. (2002), «Contagiar», en Hablemos de leer, Madrid, Anaya, pp. 11-19.

Aмо, M. del (1970), La hora del cuento, Madrid, Servicio Nacional de Lectura.

Amorós, A. (1984), "Enseñar literatura», Boletín Informativo de la Fundación Juan March, núm. 134, febrero, pp. 3-10.

Applebee, A. N. (1978), The Child's Concept of Story: Ages Two to Seventeen, Chicago, University of Chicago Press.

Argos, L. (1999), «El auge de la literatura infantil también llega a casa», El País, 31 de octubre, p. 9.

Argüeso PÉreZ, O. (2000), «Elvira Lindo: mucho más que la mamá de Manolito Gafotas», Cuadernos de Literatura Infantil y Juvenil, núm. 128, pp. 44-51.

ArizaleTA, L. (2003), La lectura ¿afición o hábito?, Madrid, Anaya.

Armijo, C. (1991), "El papel del ilustrador. Notas para una polémica», Cuadernos de Literatura Infantil y Juvenil, núm. 25, pp. 16-19.

«Arte mayor o arte menor», Cuadernos de Literatura Infantil y Juvenil, núm. 102, pp. 13-18, 1998.

AtXaga, B., e I. Ferrer (2002), El alfabeto que no llega a la i, Madrid, FADIP.

AYALA, F. (1984), "Para quién escribimos nosotros», en La estructura narrativa, Barcelona, Crítica, pp. 180-204.

AZNAR, E. (1995), "Lectura en el aula», Cuadernos de Literatura Infantil y Juvenil, núm. 72, pp. 44-48.

Baghban, M. (1990), La adquisición precoz de la lectura y la escritura, Madrid, Aprendizaje Visor.

Bajtin, M. (1989), Teoría y estética de la novela, Madrid, Taurus.

- y P. N. MEDVEDEV (1985), The formal method in literary scholarship: A critical introduction to sociological poetics, Cambridge, Harvard University Press.

BAL, M. (1995), Teoría de la narrativa. Una introducción a la narratología, Madrid, Cátedra. 
Ballaz, J. (1996), «La crítica estancada», Amigos del Libro, núm. 31, pp. 30-32.

Balzola, A. (1992), "Escuela de ballenas», Cuadernos de Literatura Infantil y Juvenil, núm. 39, pp. 8-15.

BARRENA, P. (1999), «La literatura infantil y juvenil de los años noventa ante el futuro", en Literatura para cambiar el siglo. Una revisión critica de la literatura infantil y juvenil, Salamanca, Fundación Germán Sánchez Ruipérez, pp. 35-45.

- et al. (2000), Libros infantiles y juveniles para hacer buenos lectores, Madrid, Anabad y Educación y Bibliotecas.

BARTHES, R., et al. (1966), "Introduction à l'analyse structurale du récit», Communications, núm. 8, pp. 1-27.

BAY, A. (1958), «La Littérature Enfantine», Histoire des Littératures, París, Gallimard, t. 3, pp. 1604-1621.

Belevan, H. (1976), Teoría de lo fantástico, Barcelona, Anagrama.

Benjamin, W. (1974), Reflexiones sobre niños, juguetes, libros infantiles, jóvenes y educación, Buenos Aires, Nova Terra.

Benton, M., y G. Fox (1992), Teaching Literature Nine To Fourteen, Londres, Oxford University Press.

Benveniste, É. (1966), Problemas de lingüistica general, México, Siglo XXI.

Bermejo, A. (1993), Para saber más de Literatura Infantil y Juvenil: una bibliografía, Madrid, Asociación Española de Amigos del Libro Infantil y Juvenil.

Besora, R. (editor entrevistado) (1993), "Editores del año», Cuadernos de Literatura Infantil y Juvenil, núm. 51, pp. 46-47.

Bettelheim, B. (1976), Psicoanálisis de los cuentos de hadas, Barcelona, Crítica.

- y K. ZELAN (1983), Aprender a leer, Barcelona, Grijalbo.

BiERWISCH, M. (1965), «Poetics and Linguistics», en D. C. Freeman (ed.) (1970), Linguistic and Literary Style, Nueva York, Rinhehart and Winston, pp. 96115; cit. en J. M. Pozuelo, Teoría del lenguaje literario, Madrid, Cátedra, 1988, p. 105.

Blanch, X. (2000), "Libros de un dios menor» en P. Cerrillo y J. García Padrino (coords.), Presente y futuro de la Literatura Infantil, Servicio de Publicaciones de la Universidad de Castilla-La Mancha, pp. 93-100.

Bloom, H. (1997), El canon occidental, Barcelona, Anagrama.

Boada, F. (1985), «Parlem de crítica. El Ventall de la Ventafocs», Faristol, núm. 0, julio, pp. 38-40.

- (editor entrevistado) (1993), «Editores del año», Cuadernos de Literatura Infantil y Juvenil, núm. 51, pp. 50-51.

Bonheim, H. (1982), The Narrative Modes: Techniques of the Short Story, Cambridge, Brewer.

Bоотн, W. C. (1974), La retórica de la ficción, Barcelona, A. Bosch. [Trad. de The Retoric of Fiction, 1961.] 
BORDA, I. (2002), Literatura infantil y juvenil. Teoría y didáctica, Granada, Grupo Editorial Universitario.

BORTOLussi, M. (1985), Análisis teórico del cuento infantil, Madrid, Alhambra.

Bousoño, C. (1981), El irracionalismo poético, Madrid, Gredos.

BRAGADO, M. (1999), «La función creativa del editor», en Literatura para cambiar el siglo. Una revisión crítica de la literatura infantil y juvenil, Salamanca, Fundación Germán Sánchez Ruipérez, pp. 25-33.

Brauner, A. (1951), Nos livres d'enfants ont menti, París, Sabri.

Bravo-Villasante, C. (1959), Historia de la literatura infantil española, Madrid, Doncel.

- (1970), «La ilustración en los libros infantiles», Bellas Artes, núm. 70, julio.

- (1971), Historia de la Literatura Infantil Universal, Madrid, Doncel.

- (1977), Historia y Antología de la Literatura Infantil Iberoamericana, Madrid, Doncel, 3 vols.

- (1978), «La literatura infantil española», Libro español, t. XXI, núm. 250, pp. 489-493.

- (1979-1993), Antología de la literatura infantil española, Madrid, Escuela Española, 5 vols.

- (1985a), Historia de la literatura infantil española, Madrid, Escuela Española, 6.a ed., corregida y aumentada.

- (1985b), Diccionario de autores de la Literatura Infantil mundial, Madrid, Escuela Española.

- (1988), Historia y Antología de la Literatura Infantil Universal, Madrid, Miñón, 4 vols.

- (1989), Ensayos de literatura infantil, Murcia, Universidad de Murcia.

BRÉMOND, C. (1973), Logique du récit, París, Seuil.

BRUFEE, K. (1984), "Collaborative learning and the conversation of mankind», College English, núm. 34, pp. 634-643.

- (1986), «Social construction, language and the authority of knowledge», College English, núm. 48, pp. 773-790.

BRUner, J. (1988), Realidad mental y Mundos Posibles. Los actos que dan sentido a la experiencia, Madrid, Gedisa.

BRYANT, S. C. (1972), El arte de contar cuentos, Barcelona, Nova Terra.

BüHLER, K. (1918), The Mental Development of the Child, Londres, Routledge \& Kegan Paul; en Applebee (1978).

BunburY, R., y R. TABBER (1989), «A Bicultural Study of Identification: Reader's Responses to the Ironic Treatment of a National Heroe», Children's Literature in Education, núm. 20, pp. 25-35.

Calatayud, M. (2002), «Mil años no son nada», Peonza, núm. 54-55, pp. 14-19.

CaLleja, S. (1989), La literatura infantil vasca: estudio histórico de los libros infantiles en euskera, Bilbao, Universidad de Deusto. 
Calleja, S. (1992), Todo está en los cuentos, Bilbao, Mensajero-Universidad de Deusto.

Calsamiglia, H., y A. Tusón (1999), Las cosas del decir. Manual de análisis del discurso, Barcelona, Ariel.

Cañellas, A. (1979), «Los roles sexuales en la literatura infantil», Cuadernos de Pedagogía, núm. 53, pp. 19-22.

CAparrós, M. (1995), «La ilustración de libros para niños», en Amigos del libro. Revista de la Asociación Española de Amigos del Libro Infantil y Juvenil, núm. 27, enero-marzo, pp. 29-34.

Carandell, J. M.a (1977), «Reflexiones acerca de la literatura llamada infantil. Cuatro notas sobre la literatura y los niños», Cuadernos de Pedagogía, núm. 36, pp. 20-23.

Carpenter, H., y M. Pritchard (1984), The Oxford Companion to Children's Literature, Londres, Oxford University Press.

CarranZA, M. (2002), «La carta de la señora González. Escritura experimental en un libro-álbum», Imaginaria, núm. 72.

CASTillo, M. (1994a), «Mercè Llimona», Cuadernos de Literatura Infantil y Juvenil, núm. 61, pp. 44-50.

- (1994b), "Carmen Solé Vendrell, una elección artística», Cuadernos de Literatura Infantil y Juvenil, núm. 64, pp. 44-49.

- (1994c), «Asun Balzola. Ilustración, literatura y cocina: formas del querer», Cuadernos de Literatura Infantil y Juvenil, núm. 67, pp. 44-54.

Cendán Pazos, F. (1986), Medio siglo de libros infantiles y juveniles en España (1935-1985), Madrid, Fundación Germán Sánchez Ruipérez/Pirámide.

- (2000), «Origen y primera convocatoria del Premio Lazarillo», Lazarillo, núm. 2, pp. 6-8.

Centro del Libro y de la Lectura (1990), Análisis del subsector de edición de libros infantiles y juveniles, Madrid, Ministerio de Cultura.

CERDÁ, H. (1978), Literatura infantil y clases sociales, Madrid, Akal.

- (1985), Ideología y cuentos de hadas, Madrid, Akal.

Cerrillo, P. (1990), «Literatura Infantil y Universidad», en P. Cerrillo y J. García Padrino (coords.), Literatura Infantil, Cuenca, Universidad de Castilla-La Mancha, pp. 11-19.

- (1996), "Qué leer y en qué momento», en P. Cerrillo y J. García Padrino (coords.), Hábitos lectores y animación a la lectura, Cuenca, Universidad de Castilla-La Mancha.

- (2000), «La Literatura Infantil del siglo XXI. I Encuentro "Literatura Infantil y Universidad"», Cuadernos de Literatura Infantil y Juvenil, núm. 133, pp. 51-52.

- y J. García Padrino (coords.) (1990), Poesía infantil. Teoría, crítica e investigación, Universidad de Castilla-La Mancha. 
Cerrillo, P. y J. García Padrino (coords.) (1992), Literatura infantil y enseñanza de la literatura, Cuenca, Universidad de Castilla-La Mancha.

- y J. GarCía PADRINo (coords.) (1996), Hábitos lectores y animación a la lectura, Cuenca, Universidad de Castilla-La Mancha.

- y J. García PADRINo (coords.) (1999), Literatura infantil y su didáctica, Universidad de Cuenca-Universidad de Castilla-La Mancha.

- y M. C. Utanda (2000), «Literatura infantil y universidad», Cuadernos de Literatura Infantil y Juvenil, núm. 123, pp. 24-28.

- E. Larrañaga y S. Yubero (2002), Libros, lectores y mediadores, Cuenca, Ediciones de la Universidad de Castilla-La Mancha.

Cervera, J. (1982), Historia crítica del teatro infantil español, Madrid, Editora Nacional.

- (1984), La literatura infantil en la educación básica, Madrid, Cincel-Kapelusz.

- (1988), «Lenguaje artístico y lúdico», en García Padrino y A. Medina (dirs.), Didáctica de la lengua y la literatura, Madrid, Anaya, pp. 257-277.

- (1990), «Problemas de la literatura escrita para niños», en P. Cerrillo y J. García Padrino (coords.), Literatura Infantil, Cuenca, Universidad de Castilla-La Mancha, pp. 67-84.

- (1991a), Teoría de la Literatura Infantil, Bilbao, Mensajero-Universidad de Deusto.

- (1991b), «¿La literatura infantil, obligatoria?», Cuadernos de Literatura Infantil y Juvenil, núm. 26.

- (1991c), «Nuevas tendencias de la Literatura Infantil», Infancia y Sociedad, núm. 7, enero-febrero, pp. 57-71.

- (1992), «La Literatura Infantil: momento actual y futuro», en Actas del I Congreso de la Sociedad Española de Didáctica de la Lengua y la Literatura. Sevilla, 3, 4 y 5 de diciembre de 1990, Sevilla, Departamento de Didáctica de la Lengua y la Literatura y Filologías Integradas, pp. 9-14.

- (1993), Literatura y Lengua en la Educación Infantil, Bilbao, Mensajero.

- (1995), «La literatura juvenil a debate», Cuadernos de Literatura Infantil y Juvenil, núm. 75, pp. 12-16.

- (1997), La creación literaria para niños, Bilbao, Mensajero.

Chambers, A. (1977), «The Reader in the Book: Notes from Work in Progress», Signal, núm. 23, mayo, pp. 64-87.

Chapa Eulate, V. (2000), «Presente y futuro de la Literatura Infantil y Juvenil española», en P. Cerrillo y J. García Padrino (coords.), Presente y futuro de la Literatura Infantil, Servicio de Publicaciones de la Universidad de CastillaLa Mancha, pp. 101-109.

Chartier, R. (1993), Libros, lecturas y lectores en la Edad Moderna, Madrid, Alianza Editorial. 
Chevalier, M. (1975), Cuentecillos tradicionales en la España del Siglo de Oro, Madrid, Gredos.

- (1978), Folklore y Literatura: el cuento oral en el Siglo de Oro, Barcelona, Crítica.

Cirlot, J. E. (1992), Diccionario de símbolos, Barcelona, Labor.

Clanche, P. (1978), El texto libre. La escritura de los niños, Madrid, Fundamentos.

Coloma, S. J. (2000), Ratón Pérez [versión de M. Puncel; ilustraciones de Cruz Pintor], Madrid, Asociación Española de Amigos del Libro Infantil y Juvenil.

Colomer, T. (1991), «Ultimos años de la literatura infantil y juvenil», Cuadernos de Literatura Infantil y Juvenil, núm. 26, pp. 14-24.

- (1992a), «Escrito en democracia. La literatura infantil y juvenil en castellano», Cuadernos de Literatura Infantil y Juvenil, núm. 35, pp 7-19.

- (1992b), «La literatura infantil y juvenil en España (1939-1990)», en Nobile (1992), pp. 138-167.

- (1992c), «Ampliación temática y experimentación formal en la literatura infantil y juvenil de los años 70 a los 90», en Actas del I Congreso de la Sociedad Española de Didáctica de la Lengua y la Literatura. Sevilla, 3, 4 y 5 de diciembre de 1990, Sevilla, Departamento de Didáctica de la Lengua y la Literatura y Filologías Integradas, pp. 537-541.

- (1994), «A favor de las niñas. El sexismo en la literatura infantil», Cuadernos de Literatura Infantil y Juvenil, núm. 57, pp. 7-24.

- (1995), «La adquisición de la competencia literaria», Textos de Didáctica de la Lengua y la Literatura, núm. 4, abril, pp. 8-22.

- (1996a), «El álbum y el texto», Peonza, núm. 39, pp. 27-31.

- (1996b), «Eterna Caperucita», Cuadernos de Literatura Infantil y Juvenil, núm. 87, pp. 7-19.

- (1998), La formación del lector literario, Madrid, Fundación Germán Sánchez Ruipérez.

- (1999a), «El álbum y el texto», en M. F. Paz Castillo (coord.), El libro-álbum: invención y evolución de un género para niños, Caracas, Banco del Libro, pp. 29-33.

- (1999b), Introducción a la literatura infantil y juvenil, Madrid, Síntesis.

- (2000), «Texto, imagen, imaginación», Cuadernos de Literatura Infantil y Juvenil, núm. 130, pp. 8-17.

- (2002a), «La lectura infantil y juvenil», en J. A. Millán (coord.), La lectura en España. Informe 2002, Madrid, Federación de Gremios de Editores de España, pp. 263-285.

- (2002b), "Una nueva crítica para el nuevo siglo», Cuadernos de Literatura Infantil y Juvenil, núm. 145, pp. 7-17.

- (dir.) (2002c), Siete llaves para valorar las historias infantiles, Madrid, Fundación Germán Sánchez Ruipérez. 
Colomer, T., y A. CAMPS (1991), Ensenyar a llegir, ensenyar a comprendre, Barcelona, Rosa Sensat/Edicions 62.

- y A. CAMPS (1996), Enseñar a leer, enseñar a comprender, Madrid, Celeste.

Corcoran, B., y E. Evans (eds.) (1987), Readers, Texts, Teachers, Upper Montclair (N. J.), Boynton-Cook.

Corrientes actuales de la Narrativa Infantil y Juvenil Española en lengua castellana, Madrid, Asociación Española de Amigos del Libro Infantil y Juvenil, 1990.

CouÉGNAS, D. (1992), Introduction à la paralittérature, París, Seuil.

Crago, H. (1983), Prelude to Literacy: a preschool child's encounter with picture and story, Carbondale, Southern Illinois University Press.

Cresta de Leguizamón, M. L. (1984), El niño, la literatura y los medios de comunicación masivos, Buenos Aires, Plus Ultra.

Croce, B. (1947), Breviario de estética. Cuatro lecciones seguidas de dos ensayos y un apéndice, Buenos Aires, Espasa-Calpe.

CubeLLS, F. (1990), «Corrientes actuales de la Literatura Infantil y Juvenil», en Corrientes actuales de la narrativa infantil y juvenil española en lengua castellana, Madrid, Publicaciones de la Asociación Española de Amigos del Libro Infantil y Juvenil, pp. 7-15.

Cufré, H. V. (1993), Lengua y Literatura preescolar, Madrid, Cincel, 2 vols. Vol. 2, cap. dedicado al cuento.

DAHRENDORF, M. (1980), «Del problema de los efectos de la literatura infantil y su investigación», Camp de l'arpa, núm. 73, pp. 13-16.

DANSET-LÉGER, J. (1980), L'enfant et les images de la littérature enfantine, Bruselas, Pierre Mardaga.

DAVIES, B. (1994), Sapos y culebras y Cuentos feministas, Madrid, Cátedra.

DeARDEN, C. D. (1994), «La literatura infantil y juvenil como útil de aproximación y comprensión de la diversidad cultural», en Memoria. 24. ${ }^{\circ}$ Congreso Internacional del IBBY, Sevilla, pp. 29-36.

DespinetTE, J. (1993), «Lecturas de imágenes», en V Premi Internacional Catalònia d'Il.ustració, Barcelona, Generalitat de Catalunya. Departamento de Cultura.

DesRosiers, R. (1978), La créativité verbale chez les enfants, París, PUF.

Díaz-PlajA, A. (1988), «Estilos literarios en la literatura infantil y juvenil actual», en M. P. Battaner y J. Gutiérrez Cuadrado, Llengua litèraria i Expressió escrita, Barcelona, Publicacions de la Universitat de Barcelona, pp. 19-33.

- y M. Prats (1998), «Literatura infantil y juvenil», en A. Mendoza Fillola (coord.), Conceptos clave en Didáctica de la Lengua y la Literatura, Barcelona, SEDLL, ICE Universitat de Barcelona, Horsori, pp. 191-214.

Díez, E., y F. CuBells (1973), Lectura del niño y literatura infantil, Madrid, ICCE.

DijK, T. A. van (1972), Some Aspects of Text Grammars: A Study in Theoretical Linguistics and Poetics, La Haya, Mouton. 
Dijk, T. A. van (1983), La ciencia del texto, Barcelona, Paidós.

- (1984), Texto y contexto, Madrid, Cátedra.

- (1987), «La pragmática de la comunicación literaria», en J. A. Mayoral, Estudios de pragmática literaria, Madrid, Arco/Libros, pp. 170-194.

DocAmpo, X. P. (2002), «Leer, ¿para qué?», en Hablemos de leer, Madrid, Anaya, pp. 45-66.

Donaldson, M. C. (1979), La mente de los niños, Madrid, Morata.

DoOnAN, J. (1999), «El libro-álbum moderno», en M. F. Paz Castillo (coord.), El libro-álbum: invención y evolución de un género para niños, Caracas, Banco del Libro, pp. 35-57.

Dossier (1991), "¿Quién es quién en la edición?», Cuadernos de Literatura Infantil y Juvenil, núm. 98, pp. 53-96.

DueÑAS, J. D., y R. TABERNERO (2004), «La narrativa infantil en los últimos años. Entre luces y sombras», en Aspectos didácticos de Lengua y Literatura, 13, Zaragoza, Instituto de Ciencias de la Educación, pp. 221-294.

DupONT-EsCARPIT, D. (1999), «La ilustración del libro infantil: un arte ambiguo», Peonza, núm. 51, pp. 22-29.

DurÁn, P. (2002), «De cómo la librería sirve a la biblioteca escolar», en Jornadas de Reflexión desde las Bibliotecas Escolares y Públicas, Guadalajara.

DurÁN, T. (1995), "L'imatge en el llibre il.lustrat per a infants», en La literatura infantil i la construcció d'Europa, Palma de Mallorca, Institut d'Estudis Balèarics, pp. 105-120.

- (1999), «Pero, ¿qué es un álbum?», Literatura para cambiar el siglo. Una revisión critica de la literatura infantil y juvenil, Salamanca, Fundación Germán Sánchez Ruipérez, pp. 73-82.

- (2002), Leer antes de leer, Madrid, Anaya.

- y R. Ros (1995), Primeras lecturas. Leer antes de saber leer, Barcelona, Pirene.

DuRAND, G. (1982), Las estructuras antropológicas de lo imaginario, Madrid, Taurus.

DurAND, M. (1976), L'enfant-personnage et l'autorité dans la littérature enfantine, Ottawa, Leméac.

- y G. Bertrand (1975), Limage dans le livre pour enfants, París, L'École de Loisirs.

ECO, U. (1977), Tratado de semiótica general, Barcelona, Lumen.

- (1983), Apostillas a El nombre de la Rosa, Barcelona, Lumen.

- (1985), Obra abierta, Barcelona, Planeta-Agostini.

- (1987), Lector in fabula, Barcelona, Lumen, 2. a ed.

- (1998), Los limites de la interpretación, Barcelona, Lumen.

Eguren Gutiérrez, L. J. (1987), Aspectos lúdicos del lenguaje. La jitanjáfora, problema lingüistico, Valladolid, Secretariado de Publicaciones Universitarias.

Elizagaray, A. M. (1997), «LIJ nórdica: en contra del tabú», Cuadernos de Literatura Infantil y Juvenil, núm. 97, pp. 7-18. 
El texto iluminado. Una mirada a la Ilustración Española y Latinoamericana contemporáneas, Salamanca, Fundación Germán Sánchez Ruipérez, 2002.

ENDE, M. (1982), La historia interminable, Madrid, Alfaguara.

Entrequinientos. Una selección de lecturas para niños y jóvenes, Salamanca, Fundación Germán Sánchez Ruipérez, 2000.

Equipo PeOnZA (2001), El rumor de la lectura, Madrid, Anaya.

ESCARPIT, D. (1986), La Literatura infantil y juvenil en Europa (panorama histórico), México, Fondo de Cultura Económica.

- (1996), «La ilustración en libros infantiles y juveniles», Peonza, núm. 39, pp. 14-21.

EsCARPIT, R. (1965), La revolución del libro, Madrid, Alianza Editorial.

- (1971), Sociología de la literatura, Barcelona, Oikos-Tau.

- et al. (1974), Hacia una sociología del hecho literario, Madrid, Edicusa.

Estébanez Calderón, D. (1996), Diccionario de términos literarios, Madrid, Alianza Editorial.

Even-Zohar, I. (1978), Papers in Historical Poetics, Tel Aviv, Tel Aviv University.

Fährmann, W., y M. Gómez del Manzano (1979), El niño y los libros. Cómo despertar una afición, Madrid, SM.

FAYE, J. P. (1970), Théorie du récit I, París, Seuil.

Federación de Asociaciones de Ilustradores Profesionales (2004), El Libro blanco de la ilustración, Madrid.

Federación de Gremios de Editores de España (1997), Comercio interior del libro en España 1997, Madrid.

FERNÁNDEZ, V. (1991), "Panorama de la literatura infantil y juvenil española», Cuadernos de Literatura Infantil y Juvenil, núm. 28, pp. 13-22.

- (1992), «Un año incierto», Cuadernos de Literatura Infantil y Juvenil, núm. 40, pp. 10-17.

- (1994), "Compás de espera», Cuadernos de Literatura Infantil y Juvenil, núm. 59, pp. 7-15.

- (1995), "Correcta contención», Cuadernos de Literatura Infantil y Juvenil, núm. 76, pp. 7-15.

- (1999), «Abundancias y nuevas propuestas», Cuadernos de Literatura Infantil y Juvenil, núm. 120, pp. 7-13.

- (2000a), «100 obras de literatura infantil del siglo XX», Cuadernos de Literatura Infantil y Juvenil, núm. 130, pp. 56-59.

- (2000b), «Edición abundante, escasez de lectores», Cuadernos de Literatura Infantil y Juvenil, núm. 131, pp. 7-15.

- (2004a), Anuario sobre el libro infantil y juvenil 2004, Madrid, SM.

- (2004b), «Un siglo que pudo ser de oro», en Cien años de ilustración infantil, Instituto Cervantes Virtual. 
FernÁNDEZ López, M. (1996), Traducción y Literatura Juvenil. Narrativa anglosajona, León, Universidad de León.

Fernández PaZ, A. (1998), "Contra la invisibilidad», Cuadernos de Literatura Infantil y Juvenil, núm. 103, pp. 15-18.

Ferrer, V. (2004), «1900-2002: 102 años de libros ilustrados», en Cien años de ilustración española, Centro Virtual Cervantes, pp. 1-4.

Forster, E. M. (1983), Aspectos de la novela, Madrid, Debate.

Freinet, C. (1978), El texto libre, Barcelona, Laia.

Friedman, N. (1955a), «Form of the Plot», Journal of General Education, núm. 8, pp. 241-253.

- (1955b), «Point-of-View in Fiction: The Development of a Critical Concept», en P. Stevick (ed.), The Theory of the Novel, Nueva York, Free Press, 1972.

FrYe, N. (1957), Anatomy of Criticism, Princeton, Princeton University Press.

FÜGER, W. (1972), «Zur Tiefenstruktur des Narrativen. Prolegomena zu einer generativen 'Grammatik' des Erzählens», Poetica, núm. 5, pp. 268-292.

Galán Vicedo, C. (1989), «El cuento: pequeña gran historia», Monteolivete, Departamento de Didáctica de la Lengua y la Literatura, Universidad de Valencia, núm. 6, pp. 31-36.

Gárate LarRea, M. (1994), La comprensión de cuentos en los niños, Madrid, Siglo XXI.

García Berrio, A. (1973), Significado actual del formalismo ruso, Barcelona, Planeta.

- (1989), Teoría de la literatura. La construcción del significado poético, Madrid, Cátedra.

GarCía de Enterría, M. ${ }^{a}$ C. (1983), Literaturas marginadas, Madrid, Playor.

GARCÍA LANDA, J. A. (1998), Acción, relato, discurso. Estructura de la ficción narrativa, Salamanca, Ediciones Universidad de Salamanca.

GaRCÍA PADRINO, J. (1981), «La ilustración de los libros infantiles en el contexto cultural de la España de hoy», El Libro Español, núm. 283, julio-agosto.

- (1988), «La Literatura Infantil y la formación humanística», en J. García Padrino y A. Medina (dirs.), Didáctica de la lengua y la literatura, Madrid, Anaya, pp. 535-560.

- (1992a), «El adulto mediador en la relación niño-literatura», en P. Cerrillo y J. García Padrino (coords.), Literatura infantil, Cuenca, Ediciones de la Universidad de Castilla-La Mancha, pp. 85-99.

- (1992b), «Literatura infantil y educación», en P. Cerrillo y García Padrino (coords.) (1992), pp. 9-21.

- (1992c), Libros y literatura para niños en la España contemporánea, Madrid, Fundación Germán Sánchez Ruipérez/Pirámide. 
GARCÍA PADRINO, J. (1993), «El papel de la literatura en la formación del profesorado», en L. Montero y J. M. Vez (eds.), Las didácticas específicas en la formación del profesorado, Santiago de Compostela, Universidade de Santiago de Compostela, pp. 201-212.

- (1995), «Las relaciones entre cine y Literatura Infantil en el aula. (Una propuesta didáctica)", en P. Cerrillo y J. García Padrino (eds.), El niño, la literatura y la cultura de la imagen, Cuenca, Universidad de Castilla-La Mancha, pp. 53 y ss.

- (2000), «Clásicos de la Literatura Infantil Española», en P. Cerrillo y J. García Padrino (coords.), Presente y futuro de la literatura infantil, Cuenca, Ediciones de la Universidad de Castilla-La Mancha, pp. 67-91.

- (2001), Asi pasaron muchos años... (En torno a la Literatuta Infantil Española), Cuenca, Ediciones de la Universidad de Castilla-La Mancha.

- (2004), Formas y colores: la ilustración infantil en España, Cuenca, Universidad de Castilla-La Mancha.

GaRner, M. F. (1995), Cuentos infantiles políticamente correctos, Barcelona, Circe.

GARRALÓN, A. (1999), "La crítica es bella», en Literatura para cambiar el siglo. Una revisión critica de la literatura infantil y juvenil, Salamanca, Fundación Germán Sánchez Ruipérez, pp. 35-41.

- (2004), «La crítica es bella. Cómo analizar los libros para niños», en Biblioteca Virtual Miguel de Cervantes.

Garrido DomíngueZ, A. (1993), El texto narrativo, Madrid, Síntesis.

Garrido Gallardo, M. A. (comp.) (1987), La crisis de la literariedad, Madrid, Taurus.

- (ed.) (1988), Teoría de los géneros literarios, Madrid, Arco-Libros.

GASOL, A., y A. LisSON (1989), «Realismo... ¿con apellido?», Cuadernos de Literatura Infantil y Juvenil, núm. 4, pp. 20-27.

Gaudreault, A., y A. Jost (2001), El relato cinematográfico, Barcelona, Paidós.

GenetTe, G. (1966), «Frontières du récit», Communications, núm. 8, pp. 152-163.

- (1987), Seuils, París, Seuil.

- (1989a), Figuras III, Barcelona, Lumen 1989.

- (1989b), Palimpsestos. La literatura en segundo grado, Madrid, Taurus.

- (1998), Nuevo discurso del relato, Madrid, Cátedra.

- (2004), Métalepse. De la figure à la fiction, París, Seuil.

GILI GAYA, G. (1972), Estudios de lenguaje infantil, Barcelona, Vox.

Gilman, S. (1981), Tiempo y tiempo de verbo en la poesía española, Barcelona, Laia.

Gómez CeRDÁ, A. (1990), «Libro psicológico. Relato "intrapsíquico”. Superación de problemas», en Corrientes actuales de la Narrativa Infantil y Juvenil Española en lengua castellana, Madrid, Asociación Española de amigos del Libro Infantil y Juvenil, pp. 72-77. 
GÓMeZ Del ManZANo, M. (1987), El protagonista-niño en la literatura infantil del siglo XX, Madrid, Narcea.

GómeZ-VILlalba, E., et al. (1999), "Literatura infantil y la educación literaria en los libros de texto para la Educación Primaria», Lenguaje y Textos, núm. 14, pp. 29-43.

GonZÁlez, L. D. (1997), Guía de clásicos de la Literatura Infantil y Juvenil, Madrid, Ediciones Palabra.

- (1998), Guía de clásicos de la Literatura Infantil y Juvenil (desde 1950), Madrid, Ediciones Palabra.

- (1999), Guía de clásicos de la Literatura Infantil y Juvenil. 3: Libros ilustrados, cómic, poesía, teatro y bibliografía, Madrid, Ediciones Palabra.

GREEN, R. L. (1946), Tellers of Tales, Children's Books and their Authors from 1800 to 1968, Londres, Kaye and Ward, 1969.

- (1962), «The Golden Age of Children Books», en Essays and Studies, pp. 59-73.

Greimas, A. J., y J. CourTés (1990), Semiótica. Diccionario razonado de la teoría del lenguaje, Madrid, Gredos.

GRICE, P. (1989), Studies in the Way of Words, Cambridge (Mas.), Harvard University Press.

Guía de autores, Publicaciones de la Asociación Española de Amigos del Libro Infantil y Juvenil, 1998.

Guía de lecturas infantiles, Pamplona, Eunsa, 1993

Hamburger, K. (1959), Logique des genres littéraires, París, Seuil.

HAZARD, P. (1977), Los libros, los niños y los hombres, Barcelona, Juventud, 3. ${ }^{\mathrm{a}} \mathrm{ed}$.

HeLD, J. (1981), Los niños y la literatura fantástica. Función y poder de lo imaginario, Barcelona, Paidós.

HeRnÁNDEZ, C. (1973), «Sobre el tiempo en el verbo español», Revista Española de Lingüistica, núm. 3, p. 1.

Hidalgo, M. C. (2000), «Propuesta de un método de investigación en ilustración infantil», en V. Ruzicka, C. Vázquez y L. Lorenzo (eds.), Literatura infantil y juvenil: tendencias actuales en investigación, Vigo, Editorial Universidade de Vigo, Servicio de Publicacións, pp. 69-74.

- (2001), «La ilustración infantil española actual», Cuadernos de Literatura Infantil y Juvenil, núm. 144, pp. 51-60.

Hiriart, R. (2000), Vocación y oficio: Montserrat del Amo, Madrid, Anaya.

Horna, L. de (1995), «Del oficio de ilustrador», en P. Cerrillo y J. García Padrino, (eds.), El niño, la literatura y la cultura de la imagen, Cuenca, Universidad de Castilla-La Mancha, pp. 60-66.

HuCK, Ch., et al. (1987), Children's Literature in the Elementary School, Nueva York, Holt, Rinehart and Winston, $4 .^{\mathrm{a}} \mathrm{ed}$.

Humphrey, R. (1954), Stream of Consciousness in the Modern Novel, Berkeley, University of California Press. 
HunT, P. (ed.) (1990), Children's Literature, Londres-Nueva-York, Routledge \& Kegan Paul.

- (ed.) (1995), Children's Literature and Illustrated History, Oxford-Nueva York, Oxford University Press.

Hürlimann, B. (1968), Tres siglos de literatura infantil europea, Barcelona, Juventud.

IBÁŃEZ, F. (1992), «Un sector sólido y dinámico», Cuadernos de Literatura Infantil y Juvenil, núm. 40, pp. 7-9.

Ilustradores españoles. Catálogo de la exposición presentada en el Primer Salón Internacional del Libro LIBER '83, Madrid, INL, 1983.

INGARDEN, R. (1931), L'oeuvre d'art littéraire, Lausana, L'Âge d'Homme.

IRWIN, J. (1986), Teaching Reading Comprehension Processes, Englewood (N. J.), Prentice-Hall.

ISER, W. (1987), El acto de leer, Madrid, Taurus.

JAKOBSON, R. (1981), Lingüistica y poética, Madrid, Cátedra.

JAN, I. (1977), La littérature enfantine, París, Éditions ouvrières-Dessain et Tolra.

JAuss, H. R. (1986), Experiencia estética y hermenéutica literaria, Madrid, Taurus. [1. ${ }^{a}$ ed., 1977.]

Jean, G. (1982), El poder de leer, Buenos Aires, Gedisa.

- (1988), El poder de los cuentos, Barcelona, Pirene.

JufresA, C. (editora entrevistada) (1993), «Editores del año», Cuadernos de Literatura Infantil y Juvenil, núm. 51, pp. 48-49.

- (1993), "Los ilustradores de Destino», Cuadernos de Literatura Infantil y Juvenil, núm. 54, pp. 33-35.

KAYSER, W. (1985), Interpretación y análisis de la obra literaria, Madrid, Gredos.

Kiefer, B. (1983), «The Reponses of Children in a Combination First/Second Grade Classroom to Picture Books in a Variety of artistic Styles», Journal of Research and Development in Education, 16, primavera, pp. 14-20.

- (1999), «Los libros-álbum como contextos para comparaciones literarias, estéticas y del mundo verdadero», en M. F. Paz Castillo (coord.), El libroálbum y su concepto, Caracas, Banco del Libro, pp. 65-75.

Kristeva, J. (1969), Semiótica, Madrid, Fundamentos.

- (1974), El texto de la novela, Barcelona, Lumen.

KRISTEVA, J. (1976), «Semanálisis y producción de sentido», en A. J. Greimas et al., Ensayos de semiótica poética, Barcelona, Planeta, pp. 273-306.

LaCAmbra, C. (1991), «Informe del Centro del Libro y de la Lectura», Cuadernos de Literatura Infantil y Juvenil, núm. 28, pp. 7-10.

Lage Fernández, J. J. (1991), «La psicoliteratura o "libros de familia”", Cuadernos de Literatura Infantil y Juvenil, núm. 26, pp. 52-58.

- (1995), «Psicoliteratura o libros de familia», Cuadernos de Literatura Infantil y Juvenil, núm. 69, pp. 26-36. 
Lahy-Hollebecque, M. (1928), Les Charmeurs d'enfants, París, Baudinière.

LANES, S. (1981), The art of Maurice Sendak, Londres, The Bodley Head.

Lanser, S. S. (1981), The Narrative Act: Point of View in Prose Fiction, Princeton, Princeton University Press.

Lartitegui, A. (2004), Mira qué te cuento. Ilustraciones de 30 artistas aragoneses, Madrid, Anaya.

LÁZARO CARRETER, F. (1987), «La literatura como fenómeno comunicativo», en J. A. Mayoral (comp.), Pragmática de la comunicación literaria, Madrid, Arco/Libros, pp. 151-170.

Legendre, B. (1996), Les métiers de l'édition, París, Éditions du Cercle de la Librairie.

LEWIS, D. (1996), «The Constructedness of Texts: Picture Books and the Metafictive», en S. Egoff et al. (eds.), Only Connect. Readings on Children's Literature, Oxford-NuevaYork, Oxford University Press.

- (1999), «La constructividad del texto: el libro-álbum y la metaficción», en M. F. Paz Castillo (coord.), El libro-álbum: invención y evolución de un género para niños, Caracas, Banco del Libro, pp. 77-88.

Lioni, L. (1991), «Ante las imágenes», Educación y Biblioteca, núm. 18, pp. 49-51.

LloRens GARCíA, R. F. (ed.) (2000a), Literatura infantil en la escuela, Alicante, Universidad de Alicante.

- (ed.) (2000b), Literatura infantil y lectura en el fin de siglo (1898-1998), Alicante, Universidad de Alicante.

LLUCH, G. (1996), La Literatura Infanti i Juvenil en Catalá: el Lector Model en la narrativa, Universitat de València. Tesis doctoral.

- (1998), El lector model en la narrativa per a infants i joves, Universitat Autònoma de Barcelona, Universitat Jaume I, Universitat de València.

- (1999), «Los noventa, ¿nuevos dicursos narrativos?», en Literatura para cambiar el siglo. Una revisión crítica de la literatura infantil y juvenil, Salamanca, Fundación Germán Sánchez Ruipérez, pp. 56-72.

- (2003), Análisis de narrativas infantiles y juveniles, Cuenca, Universidad de Castilla- La Mancha.

- y V. Salvador (2000), «La Cenicienta, un mito vigente», Cuadernos de Literatura Infantil y Juvenil, núm. 130, pp. 44-54.

LOBATO, A. (1992), «Suspiros de España», Cuadernos de Literatura Infantil y Juvenil, núm. 45, pp. 14-22.

- (1996), «Estudiar la ilustración hoy», Amigos del Libro, núm. 31, pp. 21-32.

López Molina, J. A. (2004), «Por una educación literaria a partir de la LIJ», Cuadernos de Literatura Infantil y Juvenil, núm. 167, pp. 1-13.

López Royo, R., y L. M. CENCERRADO MALMierCa (1997), «La literatura infantil ya tiene quien la escriba. Acercamiento al panorama de la investigación sobre literatura infantil y juvenil en España», Educación y Biblioteca, núm. 82, pp. 58-64. 
LÓPEZ TAMÉs, R. (1985), Introducción a la Literatura Infantil, Santander, Universidad de Santander.

López VAlero, A. (1992), «La literatura en Educación Infantil y Primaria», en Cerrillo y García Padrino (coords.) (1992), pp. 59-84.

LORRAINE, W. (1977), "An interview with Maurice Sendak», Wilson Library Review, vol. 52, núm. 2, pp. 153-160.

Lotman, J. (1978), La estructura del texto artístico, Madrid, Istmo.

Lozano, J., C. Peña-Marín y G. Abril (1980), Análisis del dicurso: Hacia una semiótica de la interacción textual, Madrid, Cátedra.

Luввоск, P. (1957), The Craft of Fiction, Londres, Cape.

LuKÁCS, G. (1966), Teoría de la novela, Buenos Aires, Siglo XX.

LURIE, A. (1998), No se lo cuentes a los mayores. Literatura infantil, espacio subversivo, Madrid, Fundación Germán Sánchez Ruipérez.

Machado, A. M. (1995), «Ideología y libros infantiles», en Memoria. 24. ${ }^{\circ}$ Congreso Internacional del IBBY de Literatura Infantil y Juvenil, Madrid, OEPLI, pp. 371-384.

- (2001), «Entre gansos y vacas: escuela, lectura y literatura», en La educación lectora, Madrid, Fundación Germán Sánchez Ruipérez, pp. 57-66.

MAÑÀ, T. (1992), «Ilustradores españoles: los precursores», Cuadernos de Literatura Infantil y Juvenil, núm. 39, pp. 46-50.

Marantz, K. (1999), "Con estas luces», en M. F. Paz Castillo (coord.), El libroálbum: invención y evolución de un género para niños, Caracas, Banco del Libro, pp. 7-12.

Marchamalo, J. (2004), «El mapa del tesoro», en Anuario sobre el libro infantil y juvenil 2004, Madrid, SM, pp. 9-33.

MarTín, A. (1995), «¿Por qué literatura juvenil?», Cuadernos de Literatura Infantil y Juvenil, núm. 72, pp. 24-28.

Martín Garzo, G. (2001), El hilo azul, Madrid, Aguilar.

- (2003), «Instrucciones para enseñar a un niño a leer», Blanco y Negro Cultural, 18 de abril.

Martínez ARnaldos, M. (2003), Los titulos literarios (periodisticos y cinematográficos), Madrid, Nostrum.

MarTínez Bonati, F. (1972), La estructura de la obra literaria, Barcelona, Seix Barral.

Martínez LlorCa, R. (1993a), «Mensajes en blanco y negro», Cuadernos de Literatura Infantil y Juvenil, núm. 50, pp. 16-20.

- (1993b), «El pequeño Sempé», Cuadernos de Literatura Infantil y Juvenil, núm. 54, pp. 44-47.

Martínez Menchén, A. (1971), Narraciones infantiles y cambio social, Madrid, Taurus.

MarTínez SÁnCHEZ, J. (1977), La narración infantil. Una experiencia pedagógica, Madrid, Ministerio de Educación y Ciencia. 
MaTA, G. (1999), Marketing. Vender libros, implicaciones culturales y organizativas, Madrid. [Material policopiado.]

MCEwAN, H., y K. EGAN (comps.) (1998), La narrativa en la enseñanza, el aprendizaje y la investigación, Buenos Aires, Amorrortu.

Mendoza Fillola, A. (1980), El teatro infantil español. Aspectos sociales (18751950), Barcelona, Humanitas.

- (1994), «El concepto de intertextualidad», en Didáctica de Lenguas y culturas, La Coruña, Universidade. Servicio de Publicaciones, pp. 333-343.

- (1998), Tú, lector. Aspectos de la interacción texto-lector en el proceso de lectura, Barcelona, Octaedro.

- (2001), El intertexto lector. El espacio de encuentro de las aportaciones del texto con las del lector, Cuenca, Ediciones de la Universidad de Castilla-La Mancha.

- (2004), La educación literaria. Bases para la formación de la competencia lectoliteraria, Málaga, Aljibe.

Merino, J. M.a (1990), Corrientes actuales de la Narrativa Infantil y Juvenil espanola en lengua castellana, Madrid, IBBY.

Mil años de cuentos, Madrid, Edelvives, 1995.

Ministerio de Cultura (1978), Teoría y práctica de las publicaciones infantiles y juveniles, Madrid.

Moebius, W. (1986), «Introduction to Picture-books Codes», Work \& Image, vol. 2 (2), abril-junio, pp. 141-158, en Hunt (ed.) (1990).

- (1999), «Introducción a los códigos del libro-álbum», en M. F. Paz Castillo (coord.), El libro-álbum: invención y evolución de un género para niños, Caracas, Banco del Libro, pp. 99-113.

Monográfico de la revista Peonza, núm. 39, diciembre 1996.

Monsenthal, J. (1987), "The Reader's Affective Response to Narrative Text», en R. J. Tierney et al. (eds.), Understanding Reader's Understanding, Hillsdale (N. J.), Erlbaum, pp. 95-107.

Monson, D., y R. McLenathan (1989), Crear lectores activos, Madrid, Visor.

Montero Padilla, J. (1992), "La Literatura y su enseñanza en la actualidad. (Algunos aspectos)", en Actas del I Congreso de la Sociedad Española de Didáctica de la Lengua y la Literatura. Sevilla, 3, 4 y 5 de diciembre de 1990, Sevilla, Departamento de Didáctica de la Lengua y la Literatura y Filologías Integradas, pp. 340-347.

MonTes, G. (1999), La frontera indómita. En torno a la construcción y defensa del espacio poético, México, Fondo de Cultura Económica.

Moreno, A., y L. Vera (2000), «30 años de LIJ en las universidades españolas», Cuadernos de Literatura Infantil y Juvenil, núm. 123, pp. 14-23.

Moreno, V. (1995), "Jóvenes y lectura», Cuadernos de Literatura Infantil y Juvenil, núm. 72 . 
Moreno, V. (2000), Lectura, libros y animación: reflexiones y propuestas, Editorial Gobierno de Navarra, Departamento de Educación y Cultura (col. Blitz, Ratón de Biblioteca).

Moss, A. (1992), "Varieties of Children's Metafiction», Studies in the Literary Imagination, núm. 18 (2), pp. 79-92.

Moss, E. (1981), Picture Book for Children 9-15, Stroud (Gloucester), The Timble Press.

Nobile, A. (1992), Literatura infantil y juvenil. La infancia y sus libros en la civilización tecnológica, Madrid, Morata.

Nodelman, P. (1988), Words about Pictures. The Narrative Art of Children's Literature, Athens, University of Georgia Press.

OBiols, N. (1995), «Los ilustradores ingleses», Cuadernos de Literatura Infantil y Juvenil, núm. 69, pp. 7-20.

- (1998), Cómo desarrollar los valores a partir de la literatura, Barcelona, Ceac.

- (2003), Mirando cuentos. Lo visible y lo invisible en las ilustraciones de la literatura infantil, Barcelona, Laertes

ORQuín, F. (1989), «La nueva imagen de la mujer», Cuadernos de Literatura Infantil y Juvenil, núm. 11, pp. 15-19.

ORTEGA y GASSET, J. (1923), «La doctrina del punto de vista», en El tema de nuestro tiempo, Madrid, Revista de Occidente, pp. 93-107.

Ortiz, E. (2002), Rotundifolia. Contar con los cuentos, Ciudad Real, Naque.

Osoro, K. (2000), «Creación, difusión y crítica de la literatura infantil: una aproximación desde la escuela», en P. Cerrillo y J. García Padrino, Presente y futuro de la literatura infantil, Servicio de Publicaciones de la Universidad de Castilla-La Mancha, pp. 137-150.

- (2002), «Lectura de cercanía: didáctica del sentimiento», Cuadernos de Literatura Infantil y Juvenil, núm. 45, pp. 30-36.

PACHECO, M. A. (1993), «Suspiros de ballena», Cuadernos de Literatura Infantily Juvenil, núm. 53, pp. 18-29.

- (1994), «Arte y oficio de ilustrar», en I Congreso nacional del Libro Infantil y Juvenil. Memoria, Madrid, Publicaciones de la Sociedad Española de Amigos del Libro Infantil y Juvenil, pp. 97-110.

- (1997), «La ilustración y otras artes», en ponencias del Quart Simposi Internacional Catalònia d'Il.lustració, Barcelona, Generalitat de Catalunya, Departament de Cultura.

Parmegiani, C. A. (1985), «Historia de las ilustraciones», en Parmegiani (dir.) (1985), pp. 49-72.

- (dir.) (1985), Libros y bibliotecas para niños, Madrid, Fundación Germán Sánchez Ruipérez/Pirámide.

Pastoriza de Echetbarne, D. (1972), Un oficio olvidado, el arte de narrar, Buenos Aires, Guadalupe.

Patte, G. (1987), ¡Dejadles leer! (Los niños y las bibliotecas), Barcelona, Pirene. 
Pelegrín, A. (1982), La aventura de oir, Madrid, Cincel.

- (1984), Cada cual atienda a su juego. De tradición oral y literatura, Madrid, Cincel.

- (1994), Deditos y cosquillitas, Madrid, Espasa-Calpe.

- (1996), La flor de la maravilla. Juegos, recreos, retahílas, Madrid, Fundación Germán Sánchez Ruipérez.

Pennac, D. (1993), Como una novela, Barcelona, Anagrama.

PeONZA (2004), Cien libros para un siglo, Madrid, Anaya.

PertíñeZ, J. (2000), «La ilustración infantil ante el nuevo siglo», en V. Ruzicka, C. Vázquez y L. Lorenzo (eds.), Literatura infantil y juvenil: tendencias actuales en investigación, Vigo, Editorial Universidade de Vigo, Servicio de Publicacións, pp. 401-407.

Petit, M. (1999), Nuevos acercamientos a los jóvenes y la lectura, México, Fondo de Cultura Económica.

Petrini, E. (1963), Estudio crítico de la literatura juvenil, Madrid, Rialp.

Piaget, J. (1971), Seis estudios de psicologia, Barcelona, Seix Barral.

PISANTY, V. (1995), Cómo se lee un cuento popular, Barcelona, Paidós.

Platón (1983), La República o el Estado, Madrid, Espasa-Calpe, 16.a ed.

Polanco, J. L. (1990), «Mensajes ocultos», Cuadernos de Literatura Infantil y Juvenil, núm. 13, pp. 16-22.

Pouillon, J. (1970), Tiempo y novela, Buenos Aires, Paidós.

Pozuelo Yvancos, J. M. ${ }^{a}$ (1988), Teoría del lenguaje literario, Madrid, Cátedra.

PratT, M. L. (1977), Toward a Speech Act Theory of Literary Discourse, Bloomington, Indiana University Press.

Prince, G. (1973), «Introduction à l'étude du narrataire», Poétique, núm. 14, pp. 178-196.

- (1982), Narratology: The Form and Functioning of Narrative, Berlín, Mouton.

Propp, V. (1971), Morfología del cuento. Las transformaciones de los cuentos maravillosos, Madrid, Fundamentos.

ReIs, C. (1998), Diccionario de narratología, Madrid, Cátedra.

ReoYo, R. (2001), «Los cincuenta sitios sobre LIJ que quiso encontrar en la red y nunca tuvo tiempo de buscar», Lazarillo, núm. 5, pp. 37-50.

Reuter, Y. (1988), «L'importance du personnage», Pratiques, núm. 60, pp. 3-22.

REYES, A. (1942), "Las jitanjáforas», en La experiencia literaria, Buenos Aires, Losada, pp. 193-245.

RicHARDS, J. (ed.) (1989), Imperialism and Juvenile Literature, Manchester, Manchester University Press.

Rico DE Alba, L. (1986), Castillos de arena. Ensayo sobre literatura infantil, Madrid, Alhambra.

Ricoeur, P. (1984), Temps et récit II. La configuration dans le récit de fiction, París, Seuil. 
Riffaterre, M. (1971), Essais de stylistique structurale, París, Flammarion.

Rimmon-Kenam, S. (1983), Narrative Fiction: Contemporary Poetics, Londres, Methuen.

RODARI, G. (1976), Gramática de la fantasía. Introducción al arte de inventar historias, Barcelona, Argos Vergara.

Rodríguez Almodóvar, A. (1982), Los cuentos maravillosos españoles, Barcelona, Crítica.

- (1989), Los cuentos populares o la tentativa de un lenguaje infinito, Murcia, Universidad de Murcia.

Roerich-Rubio, E. (1996), "La edición del álbum ilustrado», Peonza, núm. 39, pp. 36-37.

Rojo, G. (1974), «La temporalidad verbal en español», Verba, Universidad de Santigo de Compostela, vol. I.

Rousseau, R. L. (1994), La otra cara de los cuentos, Gerona, Tikal.

Rovira, T. (1976), Noucentisme i llibre infantil: influència del Noucentisme sobre la producció i difusió del llibre per a infants, Bellaterra, Universitat Autònoma de Barcelona, Facultat de Lletres. Tesi de llicenciatura.

- (1988), «La literatura infantil i juvenil», en Riquer, Comas, Molas, Història de la Literatura Catalana, Barcelona, Ariel, vol. XI, pp. 421-471.

Ruano, A. (1992), "Una caso insólito y mucho eclecticismo», Cuadernos de Literatura Infantil y Juvenil, núm. 39, pp. 16-20.

Ruiz CAmpos. A. (2000), Literatura infantil. Introducción a su teoría y práctica, Sevilla, Guadalmena.

Ruthrof, H. (1981), The Reader's Construction of Narrative, Londres, Routledge.

SÁrz Ripoll, A. (1991), Análisis de un modelo textual. Mecanismos y estructuras del discurso persuasivo dirigido a la infancia, Tarragona. Tesis doctoral inédita.

- (1993), "Años 60, nuevos horizontes», Cuadernos de Literatura Infantil y Juvenil, núm. 53, pp. 7-17.

SALWAY, E. (comp.) (1986), Reading about Children's Books. An introductory guide to books about children's literature, Londres, National Book League.

SÁNCHEZ CORRAL, L. (1992), «(Im)posibilidad de la Literatura Infantil: hacia una caracterización estética del discurso», Cauce, núms. 14-15, pp. 525-560.

- (1995), Literatura infantil y lenguaje literario, Barcelona, Paidós.

SÁnchez Ferlosio, R. (1972), "Prólogo», en C. Collodi, Pinocho, Madrid, Alianza Editorial.

SÁNCHEZ ReY, A. (1991), El lenguaje literario de la «nueva novela» hispánica, Madrid, Fundación Mapfre.

SARTO, M. (1968), «La literatura para niños en lengua castellana», en B. Hürlimann, Tres siglos de literatura infantil europea, Barcelona, Juventud, pp. 293-313.

- (1985), Animación a la lectura. Para hacer al niño lector, Madrid, SM.

- (1998), Animación a la lectura con nuevas estrategias, Madrid, SM. 
SARTO, M., y P. CAREAGa (1999), «Animación a la lectura con nuevas estrategias», Amigos del Libro, núm. 43-44, pp. 63-66.

SATUÉ, E. (1998), El diseño de libros del pasado, del presente y tal vez del futuro, Salamanca. Fundación Germán Sánchez Ruipérez.

SAVATER, F. (1988), «Lo que enseñan los cuentos», Cuadernos de Literatura Infantil y Juvenil, núm. 1, pp. 8-12.

Schmid, W. (1973), Der Textaufbau in den Erzählungen Dostoevskijs, Múnich, Fink.

SCHMidT, S. (1987), «La communication littéraire», en J. A. Mayoral (ed.), Pragmática de la comunicación literaria, Madrid, Arco-Libros, pp. 194-212.

SCHuwer, Ph. (1994), Traité pratique d'édition, París, Éditions du Cercle de la Librairie.

SCIACCA, G. M. (1965), El niño y el folklore, Buenos Aires, Eudeba.

SeArle, J. (1980), Actos de habla, Madrid, Cátedra.

SEgre, C. (1985), Principios de análisis del texto literario, Barcelona, Crítica-Grijalbo.

SELDEN, R. (1987), Teoría literaria contemporánea, Barcelona, Ariel.

Shavit, Z. (1986), Poetics of Children's Literature, Athens-Londres, The University of Georgia Press.

Shklovski, V. (1925), O teorii prozy, Moscú, Federatsia.

SHulevitz, U. (1996), "What is a Picture Book», en S. Egoff et al. (eds.), Only Connect. Readings on Children's Literature, Oxford-Nueva York, Oxford University Press.

- (1999), "¿Qué es un libro-álbum?», en M. F. Paz Castillo (coord.), El libroálbum: invención y evolución de un género para niños, Caracas, Banco del Libro, pp. 129-132.

Soriano, M. (1968), Les contes de Perrault: Culture savante et traditions populaires, París, Gallimard.

- (1995), La literatura para niños y jóvenes. Guía de exploración de sus grandes temas, Buenos Aires, Ediciones Colihue.

SOTOMAYOR, V. (1998), «El género epistolar», Cuadernos de Literatura Infantil y Juvenil, núm. 109, pp. 7-19.

- (2000), «Lenguaje literario, géneros y literatura infantil», en P. Cerrillo y J. García Padrino (coords.), Presente y futuro de la Literatura Infantil, Servicio de Publicaciones de la Universidad de Castilla-La Mancha, pp. 27-65.

Spang, K. (1991), Teoría del drama, Pamplona, Eunsa.

- (1993), Géneros literarios, Madrid, Síntesis.

SpInK, J. (1990), Niños lectores, Madrid, Fundación Germán Sánchez Ruipérez/Pirámide.

Staiger, E. (1966), Conceptos fundamentales de poética, Madrid, Rialp.

STANZEL, F. K. (1955), Die typischen Erzählsituationen im Roman, Viena, Braumüller. 
Stanzel, F. K. (1984), A Theory of Narrative, Cambridge, Cambridge University Press.

STEINER, G. (2003), Lenguaje y silencio, Barcelona, Gedisa.

SZERTICS, J. (1967), Tiempo y verbo en el romancero viejo, Madrid, Gredos.

TABERNERO, R. (1998), «Manolito Gafotas: el narrador de la literatura infantil de los 90», Amigos del Libro Infantil y Juvenil, núms. 411-412, pp. 7-22

- y R. Justes (1995), «Un nuevo concepto de teatro: Edelmiro II y el dragón Gutiérrez de F. Lalana», en Aspectos de didáctica de la lengua y la literatura (2). Actas del III Congreso Internacional de la Sociedad Española de Didáctica de la Lengua y la Literatura 1994, Murcia, Universidad de Murcia, pp. 801-806.

TACCA, O. (1973), Las voces de la novela, Madrid, Gredos.

TEIXIDOR, E. (1995), «La literatura juvenil: las reglas del juego», Cuadernos de Literatura Infantil y Juvenil, núm. 72, pp. 8-15.

Tejerina, I. (1993), Estudios de los textos teatrales para niños, Santander, Universidad de Cantabria.

- (1994), Dramatización y teatro infantil, Madrid, Siglo XXI.

Todorov, T. (1966), «Les catégories du récit litteraire», Communications, núm. 8, pp. 125-151.

- (1975), Poética, Buenos Aires, Losada.

- (1982), Introducción a la literatura fantástica, Barcelona, Buenos Aires.

- (1983/1987), «Sobre el conocimiento semiótico», en Garrido Gallardo, (comp.) (1987), pp. 27-47.

Tolkien, J. R. R. (1964), Tree and Leaf, Londres, Georges Allen \& Unwin.

TOMASHEVSKI, B. (1982), Teoría de la literatura, Madrid, Akal.

TORAL, C. (1957), Literatura Infantil española. (Apuntes para su historia), 2 vols., Madrid, Coculsa.

- (1963), «Literatura infantil de todos los países», en Los mejores cuentos juveniles de la literatura universal, Barcelona, Labor, tomo 1, pp. 1-95.

Townsend, J. R. (1974), «Standards of Criticism for Children's Literature», Children's Service. Signal 14, mayo, Timble Press, pp. 91-105.

TRIGON, J. (1950), Histoire de la littérature enfantine: de ma mère L'Oye au Roi Babar, París, Hachette.

TURIN, A. (1995), Los cuentos siguen contando... Algunas reflexiones sobre los estereotipos, Madrid, Horas y Horas.

Uspensky, B. (1973), A Poetics of Composition: The Structure of the Artistic Text and Typology of a Compositional Form, Berkeley, University of California Press.

VAX, L. (1981), Las obras maestras de la literatura fantástica, Madrid, Taurus.

VÁzquez, M. (1993), «Literatura infantil y crítica literaria», Primeras Noticias, núm. 121, pp. 23-30.

VÁzQuez, J. M. (1963), La prensa infantil en España, Madrid, Doncel. 
Ventura, A. (2004), «Las técnicas en la ilustración infantil», en Cien años de ilustración española, Centro Virtual Cervantes, pp. 1-4.

VIALA, A. (1987), «L'enjeu en jeu: lecture littéraire et rhétorique du lecteur», en M. Picard (ed.), La lecture littéraire, París, Clancier-Guénaud, pp. 15-31.

VIGOTSKI, L. S. (1979), El desarrollo de los procesos psicológicos superiores, Barcelona, Crítica.

- (1982), La imaginación y el arte en la infancia, Madrid, Akal.

VillanueVA, D. (1984), «Narratario y lector implícito», en L. T. González del Valle y D. Villanueva (eds.), Estudios en honor de R. Gullón, Society of Spanish Studies, pp. 343-346.

Vitoux, P. (1982), «Le jeu de la focalisation», Poétique, núm. 51, pp. 359-368.

Wall, B. (1991), The Narrator's Voice. The Dilemma of Children's Fiction, Londres, Macmillan.

WaTsOn, G. (1979), The Story of the Novel, Londres, Macmillan.

WeLls, G. (1988), Aprender a leer y escribir, Barcelona, Laia.

WenselL, U. (2000), «El papel de las ilustraciones en la difusión de los libros para niños», en P. Cerrillo y J. García Padrino (coords.), Presente y futuro de la literatura infantil, Cuenca, Ediciones de la Universidad de Castilla-La Mancha, pp. 151-156.

Winnicot, D. W. (1993), Realidad y juego, Barcelona, Gedisa.

YNDURÁIN HERNÁNDEZ, F. (1974), «Para una función lúdica en el lenguaje», en Doce ensayos sobre el lenguaje, Madrid, Rioduero, pp. 215-227. Publicado por primera vez en el Boletín Informativo de la Fundación March (1973), núm. 19, pp. 365-373.

Yubero, S., M. C. Utanda, P. Cerrillo y C. Cañamares (2002), Yo leo, tú lees, él lee... Libros para todos, Cuenca, Universidad de Castilla-La Mancha.

ZIPES, J. (1986), Les contes de fées et l'art de la subversion, París, Payot. 


\section{ÍNDICE}

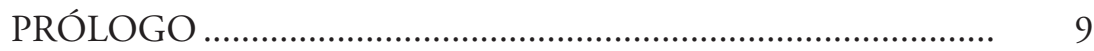

INTRODUCCIÓN ................................................................ 13

CAPÍTULO 1. LITERATURA INFANTIL: APROXIMACIÓN

AL ÁMBITO DE ESTUDIO ................................................... 21

1.1. Para comenzar ...................................................................... 21

1.2. El didactismo en el discurso literario infantil y juvenil .......... 26

1.3. Nuevos caminos en la creación ............................................. 28

1.4. El desarrollo de los estudios sobre literatura infantil ............. $\quad 30$

1.4.1. Los estudios históricos .............................................. 32

1.4.2. Otras perspectivas .................................................... 35

1.4.3. Por fin, la perspectiva literaria .................................... $\quad 39$

1.5. ¿Y la educación literaria? ....................................................... 48

1.6. La literatura infantil en el marco de la enseñanza ................... 53

1.7. Para terminar ................................................................... 56

CAPÍTULO 2. OTRAS FORMAS DE CONTAR: LOS PARATEXTOS EN EL DISCURSO NARRATIVO INFANTIL .......... $\quad 57$

2.1. Los paratextos no verbales .................................................... 68

2.1.1. La ilustración ........................................................... 70

2.1.1.1. Las funciones de la ilustración ..................... 74

2.1.1.2. El libro-álbum ............................................ 75

2.1.1.3. ¿Cómo interactúan imagen y texto y construyen los significados en el libro-álbum? .... $\quad 78$

2.1.1.4. Los pictogramas ......................................... 87

2.1.1.5. El libro ilustrado ........................................ 90

2.1.1.6. ¿La ilustración puede definirse como paratexto? 92 
2.1.2. El peritexto editorial ................................................. 93

2.1.2.1. La edad del lector ...................................... 94

2.1.2.2. La cubierta y la contracubierta ................... 95

2.1.2.3. Los catálogos ............................................ 125

CAPÍTULO 3. DE CONTADORES, CUENTOS Y CON-

TADOS

3.1. El autor ....................................................................... 140

3.1.1. Los títulos en el discurso narrativo infantil literario ... 142

3.1.2. Los intertítulos ...................................................... 147

3.1.3. Los prólogos y dedicatorias ...................................... 152

3.2. El narrador .................................................................. 157

3.2.1. La identidad del narrador ........................................ 159

3.2.1.1. La participación en la historia .................... 160

3.2.1.2. Narrador único o narrador múltiple ............ 164

3.2.1.3. Las funciones del narrador ......................... 170

3.2.2. El grado de información del narrador .......................... 173

3.2.3. La situación del narrador ........................................... 177

3.2.3.1. La situación del narrador respecto de la historia 177

3.2.3.2. La perspectiva del narrador. La focalización . 184

3.2.4. El momento en el que se narra ................................ 195

3.2.5. La implicación del narrador ..................................... 198

3.3. El narratario .................................................................. 204

3.3.1. El narratario en el discurso narrativo literario infantil 205

3.3.2. La identidad del narratario ...................................... 205

3.3.3. El grado de conocimiento del narratario. La perspectiva 218

3.4. El lector textual ............................................................. 224

3.4.1. El lector textual en la narrativa infantil .......................... 225

3.4.2. La intertextualidad. Tejiendo textos ........................... 227

3.4.3. La duplicidad del destinatario .................................. 234

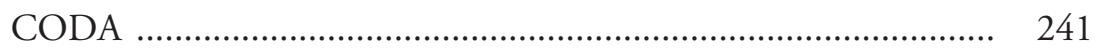

ANEXO. DISTRIBUCIÓN DE OBRAS MENCIONADAS POR

EDADES …................................................................. 245

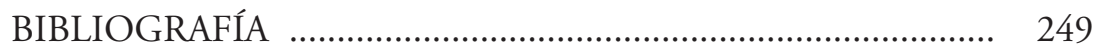


Este libro se terminó de imprimir en los talleres gráficos de INO Reproducciones, S. A., de Zaragoza,

el día 20 de octubre de 2005

QP 


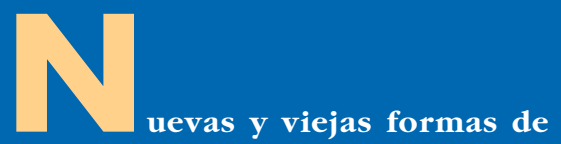

contar, nuevos y viejos contadores, nuevos y viejos "contados" porque el receptor del discurso literario infantil en los umbrales del siglo xxI nace a la lumbre de la tradición oral para aproximarse con naturalidad a un discurso imbuido de las notas de la sociedad en la que se desarrolla. La contemplación del texto en el interior del acto de la comunicación descubre un discurso marcado por la existencia de un destinatario definido por la duplicidad. Este lector corresponde a las condiciones propias de una sociedad posindustrial, democrática, una sociedad en la que los medios audiovisuales imprimen nuevos modos de aproximación a los mensajes.

Así pues, las formas de contar han ido evolucionando y se han adaptado al nuevo milenio. El contador tradicional ha sido sustituido por la ilustración, las recepciones ya no son colectivas sino individuales, autores e ilustradores comparten autoria y la imagen presta nuevos cauces a la creación. Caminamos en los umbrales del siglo xxi hacia un discurso literario más arriesgado en sus propuestas, que incorpora modelos de la literatura para adultos y que acuña los propios en aras del receptor, en el que se inserta el mediador adulto. Múltiples son, sin embargo, los factores que pueden frenar este desarrollo: desde el mercado editorial o el descuido de la educación literaria hasta la necesidad de orientar y de enseñar de una forma explícita - en una suerte de escolarización de la literatura - a un receptor infantil en el que no se acaba de confiar. El futuro parece apostar por la calidad literaria, al menos en parte de lo que hoy se muestra al lector del nuevo siglo. Eso sí, existe otro tipo de oferta, quizá más rentable, que no augura unos tiempos tan saludables. Pero, esa es otra historia...
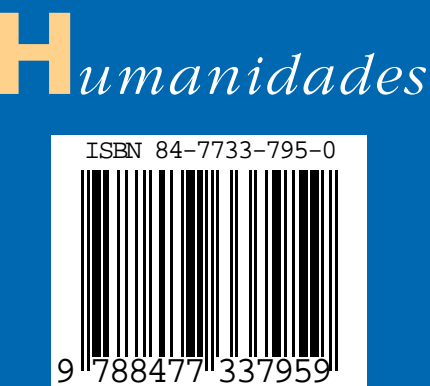